August 1999 • NREL/TP-570-26797

\title{
Bibliography of Work on the Heterogeneous Photocatalytic Removal of Hazardous Compounds from Water and Air
}

\section{Update Number 3 to January 1999}

\author{
Daniel M. Blake
}
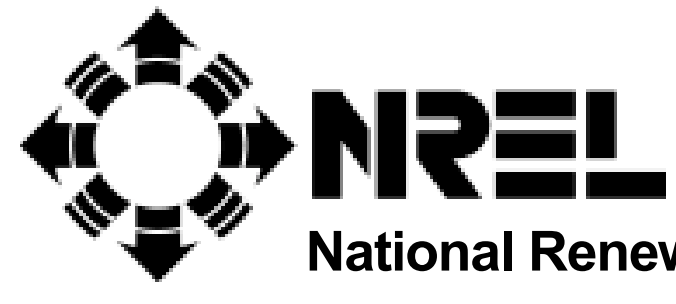

National Renewable Energy Laboratory

1617 Cole Boulevard

Golden, Colorado 80401-3393

NREL is a U.S. Department of Energy Laboratory

Operated by Midwest Research Institute $\bullet$ Battelle $\bullet$ Bechtel

Contract No. DE-AC36-98-G010337 


\section{Bibliography of Work on the Heterogeneous Photocatalytic Removal of Hazardous Compounds from Water and Air}

Update Number 3 to January 1999

Daniel M. Blake

Prepared under Task No. DO6E4300

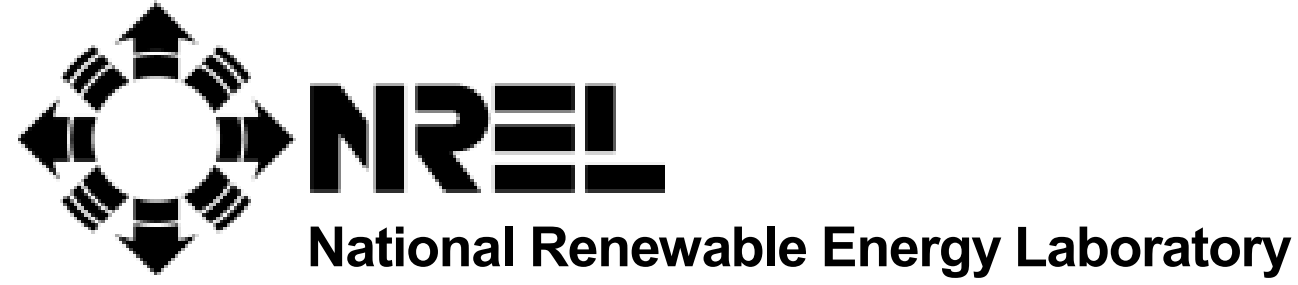

1617 Cole Boulevard

Golden, Colorado 80401-3393

NREL is a U.S. Department of Energy Laboratory

Operated by Midwest Research Institute $\bullet$ Battelle $\bullet$ Bechtel

Contract No. DE-AC36-98-G010337 


\section{NOTICE}

This report was prepared as an account of work sponsored by an agency of the United States government. Neither the United States government nor any agency thereof, nor any of their employees, makes any warranty, express or implied, or assumes any legal liability or responsibility for the accuracy, completeness, or usefulness of any information, apparatus, product, or process disclosed, or represents that its use would not infringe privately owned rights. Reference herein to any specific commercial product, process, or service by trade name, trademark, manufacturer, or otherwise does not necessarily constitute or imply its endorsement, recommendation, or favoring by the United States government or any agency thereof. The views and opinions of authors expressed herein do not necessarily state or reflect those of the United States government or any agency thereof.

Available to DOE and DOE contractors from:

Office of Scientific and Technical Information (OSTI)

P.O. Box 62

Oak Ridge, TN 37831

Prices available by calling 423-576-8401

Available to the public from:

National Technical Information Service (NTIS)

U.S. Department of Commerce

5285 Port Royal Road

Springfield, VA 22161

$703-605-6000$ or $800-553-6847$

or

DOE Information Bridge

http://www.doe.gov/bridge/home.html

Printed on paper containing at least $50 \%$ wastepaper, including $20 \%$ postconsumer waste 


\section{Summary}

The subject of this report is chemistry and engineering for the application of heterogeneous photocatalysis. The state of the art in catalysts are forms of titanium dioxide or modifications thereof, but work on other heterogeneous catalysts is included in this compilation.

This report is a continuation the bibliographies of work on the photocatalytic oxidation of organic or inorganic compounds in air or water and on the photocatalytic reduction of inorganic compounds in water that were published in May 1994, October 1995, and January 1997. The previous reports included 663, 574, and 518 citations, respectively. This update contains 1,517 new references. These were published between October 1996 and January 1999, or are references from prior years that were not included in the previous reports. The general focus of the work is removing hazardous chemical or biological contaminants from air, water, and surfaces. This report also references work on properties of semiconductor photocatalysts and the application of photocatalytic chemistry in organic synthesis. The organization is the same as in the previous reports in this series except that patents are included as a separate list because of the large number that have appeared since the last report. The first part of the report gives citations for work done in a few broad categories that are generic to the process. Three tables provide references to work on specific substances. The first covers organic compounds that are included in various lists of hazardous substances identified by the U.S. Environmental Protection Agency (EPA). The second lists compounds not included in that table, but that have been treated in a photocatalytic process. The third covers inorganic compounds that have been treated by a photocatalytic process. 


\section{Table of Contents}

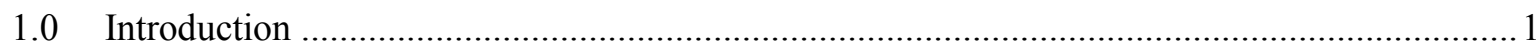

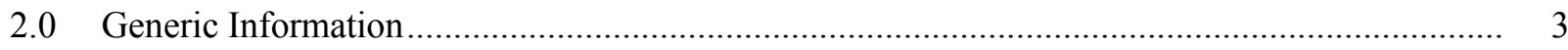

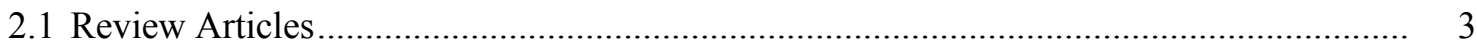

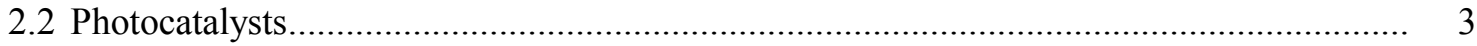

2.2.1 Modified Titanium Dioxide ....................................................................... 4

2.2.2 Hydrophobic Surface Treatment............................................................... 4

2.2.3 Dye Sensitized Titanium Dioxide..................................................................... 4

2.2.4 Metal Ion Doping of Titanium Dioxide ...................................................... 4

2.2.5 Metallized Titanium Dioxide.................................................................. 5

2.2.6 Other Semiconductors .............................................................................. 5

2.2.7 Immobilized Photocatalysts .................................................................... 5

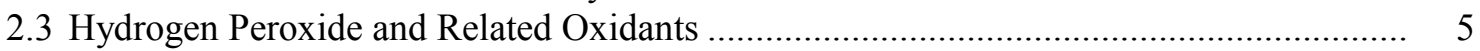

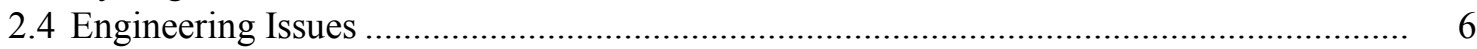

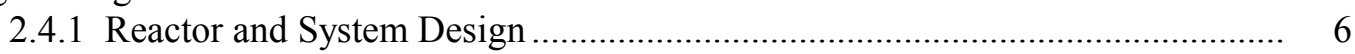

2.4.2 Systems Analysis ........................................................................ 6

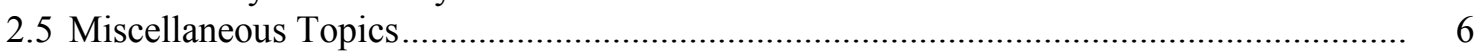

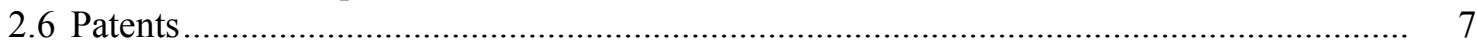

2.7 Companies Active in the Field .............................................................................. 7

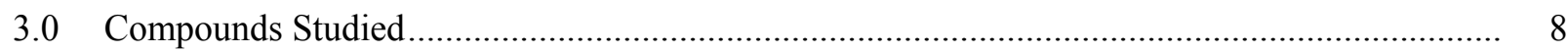

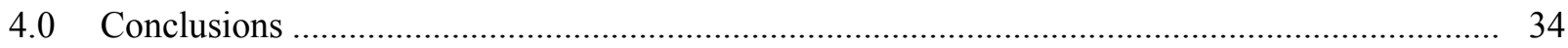

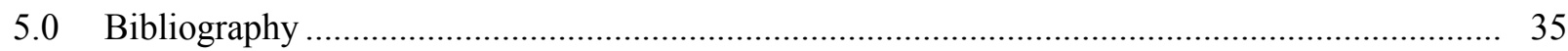

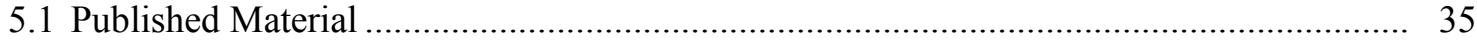

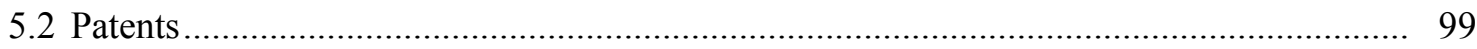

5.3 Address for Sending Corrections or Additions to the Bibliography .................................. 152

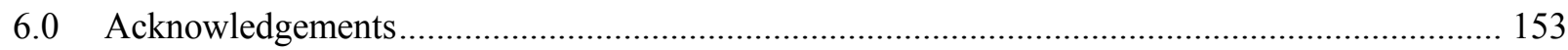

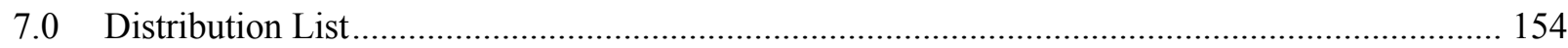




\subsection{Introduction}

This update in combination with the previous reports ${ }^{1,2,3}$ provides a comprehensive bibliography of the work on photocatalytic chemistry and processes that are available in the open literature. It will be of most use to scientists and engineers interested in the use of heterogeneous photocatalytic oxidation or reduction processes in environmental remediation, process emission control, indoor air quality, or other applications in which oxidation or reduction chemistry on illuminated semiconductor surfaces can occur. Because of the large number of documents, no attempt has been made to critically assess the information in the cited literature. The combined reports include more than 3,300 citations to work published between 1970 and the beginning of 1999. The literature cited includes U.S. and foreign patents. Information was compiled by manually scanning the literature and by searching commercial databases. This update includes about 100 citations to work done before 1996 that were not included in the previous reports. Some citations have doubtless been missed and topics covered in some papers may not have been identified and covered in every appropriate category. The author is grateful to the many people who sent references and reprints of their work. Coverage is limited to heterogeneous processes, except in a few cases where review material for homogeneous processes is relevant to heterogeneous photocatalytic chemistry. The author invites readers to send references to relevant work that appeared before 1999 that has been missed to the mailing or e-mail address included in Section 5.3.

The number of new publications, including patents, continues to grow each year, as shown in the plot in the figure. The growth in patents is primarily due to the high level of commercial interest in applications being developed in Japan. The number of papers, reports, and conference proceedings has leveled off at about 300 per year, with an increasing fraction coming from outside the United States.

The photocatalytic oxidation of organic compounds in water has received the most attention, but there is a rapidly increasing amount of work on the oxidation of volatile organic or inorganic compounds in the gas phase. Photocatalytic reduction of organic compounds and metal-containing ions has also received increasing attention. Studies of cell killing and disinfection by illuminated titanium dioxide $\left(\mathrm{TiO}_{2}\right)$ have also been increasing in number. Nearly 1,000 substances have been tested to date.

Intermediates and by-products have been widely observed to form and persist in the treated medium. These can include a variety of mineral acids, oxygenated organic compounds, and carbon monoxide. The nature of the intermediates can be used as a tool for revealing details of the chemical mechanism for the photocatalytic process. The net process involves oxidizing the organic compound to an intermediate stage of oxygen content or to carbon dioxide, water, and a mineral acid (if a heteroatom such as nitrogen

\footnotetext{
${ }^{1}$ Blake, Daniel M. (1994). Bibliography of Work on the Photocatalytic Removal of Hazardous Compounds from Water and Air. NREL/TP-430-6084. Golden, CO: National Renewable Energy Laboratory. 75 pp. [DE94006906]. Available from the National Technical Information Service, Springfield, VA 22161.

${ }^{2}$ Blake, Daniel M. (1995). Bibliography of Work on the Photocatalytic Removal of Hazardous Compounds from Water and Air. Update Number 1, to June 1995. NREL/TP-473-20300. Golden, CO: National Renewable Energy Laboratory. 102 pp. Available from the National Technical Information Service, Springfield, VA 22161.

${ }^{3}$ Blake, Daniel M. (1997). Bibliography of Work on the Photocatalytic Removal of Hazardous Compounds from Water and Air. Update Number 2, to October 1996. NREL/TP-430-22197. Golden, CO: National Renewable Energy Laboratory. 88 pp. Available from the National Technical Information Service, Springfield, VA 22161.
} 


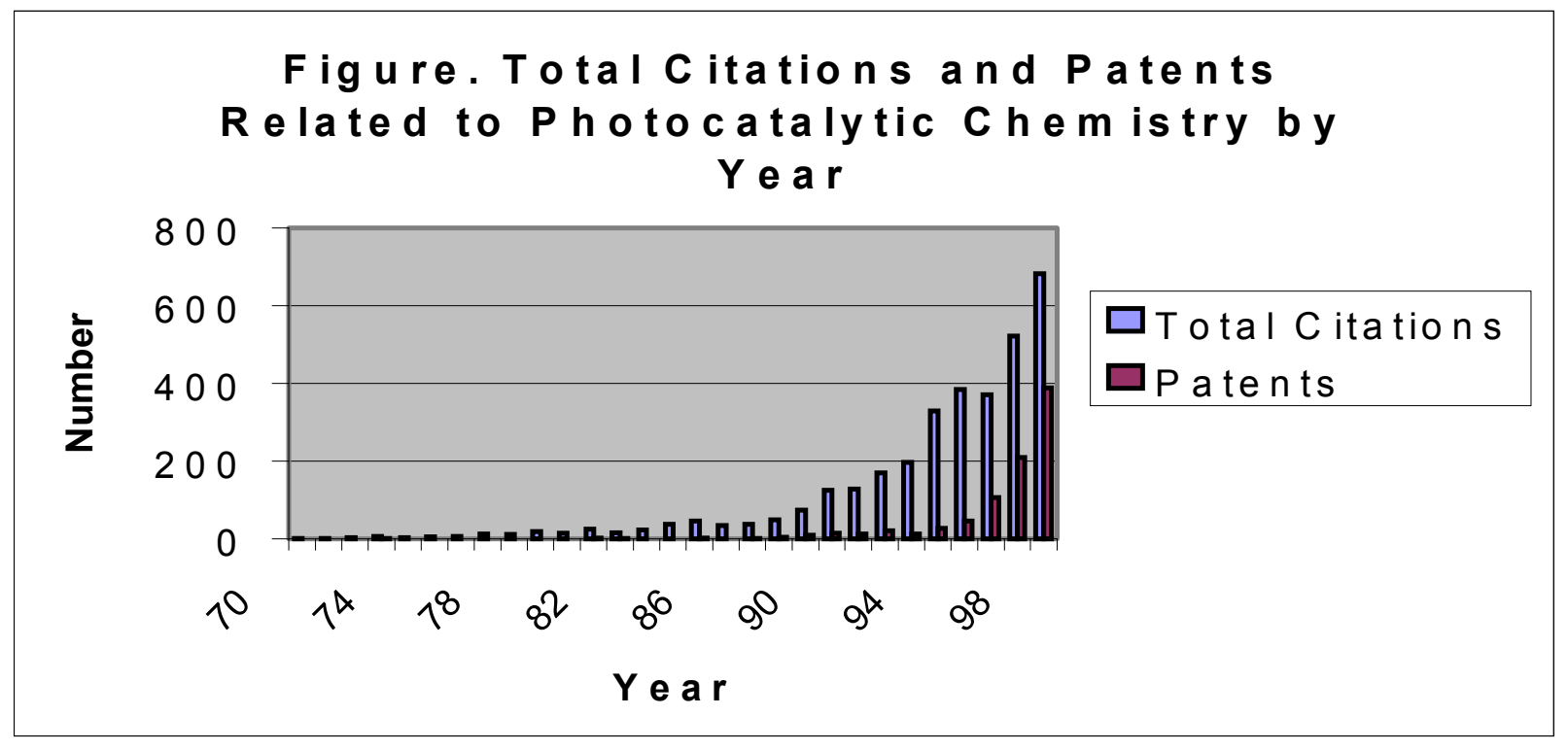

or chlorine is present). Other oxidizing agents may be substituted for oxygen. Certain metal ions from water can be modified or removed when the ions replace oxygen as the electron acceptor in the process and are deposited as lower oxidation state oxides or metals on the surface of the photocatalyst. These processes are more efficient when sacrificial electron donor compounds are provided.

Reference to new test work on about 375 compounds is included in the tables in Section 3. The moststudied compounds are phenol derivatives, BTEX (benzene, toluene, ethyl benzene, and xylene) components found in fuel spills, oxides of nitrogen, and chlorinated solvents such as tri- and perchloroethylene and chloroform. A significant number of pesticides, dye compounds, and surfactants has been shown to be mineralized and a variety of bacteria, viruses, cancer cells, and other cell types has been found to be killed by irradiation with near-ultraviolet light in the presence of titanium dioxide. The breadth of work attests to the very wide range of applications that are being considered for the technology. The self-cleaning and wetting properties of irradiated titanium dioxide surfaces are now the subjects of a high level of interest because of the potential for commercial applications.

The section on companies active in the field was not updated for this report because little new information was available to the author. The high level of R\&D activity by Japanese companies is indicated by the large number of patents assigned to them (see the patent list in Section 5.2). However, the author has little information on the individual Japanese companies that actively commercialize products.

The following sections cover reviews written on various aspects of the technology, work in developing and testing photocatalysts and oxidants, engineering issues, other topics, and patents. These sections include information that can apply to a range of applications. They are followed by tables listing references to work performed on specific substances. References to work on systems in which the compound to be treated is carried in the gas phase or on a surface exposed to air are indicated by the prefix "g" in the citation number. 


\subsection{Generic Information}

This section references work that spans the field of photocatalytic processes.

\subsection{Reviews and Articles}

Reviews have been written covering many aspects of photocatalytic chemistry and technology. This section also includes reviews written before 1999 that were not cited in the previous reports. Reviews covering the broad topics given can be found in the following:

Semiconductors and supports - 104, 232, 326, 407, 542, 604, 800, 834, 840, 841; methodology for comparing reaction systems - 56, 90, 235, 236, 669, 670; mechanisms/activity - 33, 55, 57, $164,165,222,255,256,299,368,405,407,802,854,857$; nanocrystalline semiconductors - 19, 371; photoelectrochemical systems - 75, 106, 255, 256, 433, 490; solar - 13, 15, 16, 28, 29, 31, $32,56,75,77,153,164,165,235,236,237,242$; companies active in the field $-591,760,816$, 817 ; adsorption - 104; self-cleaning surfaces - 217, 218, 222, 256, 257, 565, 640, 645, 751, 810, 817; disinfection, cell killing, and toxicology - 79, 104, 217, 220, 221, 222, 252, 256, 257, 490, $514,550,565,640,650,738,748,792,793,806,810,826$; water treatment $-54,56,57,118$, $219,220,252,373,433,445,490,581,592,729,730$; indoor air quality - 22, 220, 221, 222, 256, $257,323,372,514,518,549,550,565,640,792,793,821$; environmental applications - 26, 54, $57,222,224,232,234,235,236,252,330,376,405,485,490,500,514,539,565,575,591$, $679,745,783,854,857$; energy storage - no new reports; preparation and applications of semiconductor thin films and coatings - 26, 29, 31, 48, 223, 224, 314, 565, 592, 834; iron doped titanium dioxide as photocatalysts - 425; organic synthesis - 560; intercalation compounds - no new reports; oxidation of chlorophenols - 105; comparison of advanced oxidation processes 118,485 ; issues and questions in application of photocatalysis -77 ; reactors $-56,77,235,236$, 242, 336; problems of immobilization of catalyst - 433, 592; supported photocatalysts - 592, 680; fate of organic nitrogen - 667; photocatalytic ammonia synthesis - no new reports; activation of oxygen - 317; surfactant removal - 445, 540; charge injection into semiconductor particles - ; activating titanium dioxide with visible light $-28,29,31,32,75$; specialty grades of titanium dioxide - 19, 371, 372, 373, 518, 559, 728, 840, 841; photochemistry on surfaces - 33, 407; comparison of advanced pollution control methods - 126, 252; mechanisms of polymer degradation - 286; photography and imaging - 426, 481, 641; analytical chemistry applications 430,581 .

\subsection{Photocatalysts}

The nature of the photocatalyst determines the rate and efficiency of the process. The anatase form of titanium dioxide has the desirable properties of being chemically stable, readily available, and active as a catalyst for oxidation processes. The $3.2 \mathrm{eV}$ band gap matches the output of a wide variety of readily available lamps but is not ideal for solar applications. Rutile has a smaller band gap, $3.0 \mathrm{eV}$, but only a few reports observe photocatalytic activity for this form. The photo efficiency for reaction of target molecules is generally rather low, particularly for the aqueous phase processes. A major body of work has been directed toward modifying titanium dioxide and testing other semiconductors to identify ways to increase process efficiency and to improve the overlap of the absorption spectrum of the photocatalyst with the solar spectrum. This work is broken down into a few broad categories and covered in the references cited. 


\subsubsection{Modified Titanium Dioxide}

Titanium dioxide and modified forms, including commercially available forms, heat-treated materials, and materials prepared by a range of techniques:

sol-gel - 14, 51, 74, 100, 207, 208, 209, 210, 243, 253, 258, 279, 284, 314, 343, 369, 392, 440, $441,474,499,535,551,577,578,579,613,658,693,703,733,734,815,824,829,830,835$; controlled hydrolysis of $\mathrm{TiCl}_{4}$ or $\mathrm{Ti}(\mathrm{OR})_{4}-315,369,808,809,851$; heat treatment $-306,343$, $517,550,552,631,655,703,822,830$; colloidal, quantized or nano-crystalline $-4,51,59,60$, $61,89,90,245,246,306,307,345,360,375,386,706,707,714,775,835$; nanotubules -392 , 393; xerogel/aerogel - 172; mesoporous - 156, 179, 211, 472, 473; electrophoretic coating - 107, 108; flame synthesis - 40, 197, 841; titanium dioxide from different vendors - 90, 109, 110, 127, $128,151,175,197,355,369,371,372,421,422,497,518,543,559,600,622,643,668,684$, $753,760,786,816,817$; spray pyrolysis $-37,107,360,527,800$; plasma enhanced chemical vapor deposition - 117, 503; sputtered - 144, 568, 176, 655, 677; epitaxial growth -125 ; anodized titanium metal - 277, 550; electrocomposite deposition - 814; impregnation - 831, 832, 833; co-precipitation - ; microemulsion - 678; microroughened - 158, 711; reduction - ; dip or spin coating $-251,440,441,510,520,528,550,645,829$; thermal spraying $-41,650$; screen printing - 631; rutile $-51,125,296,368,380,438,487,502,517,555,556,711,753$; pillared and layered titanates - 753; cysteine - 486, 746; surface modification - 132, 133, 610, 746, 848, 849; ion implantation - 28, 29, 30, 31, 311; fluoride effect on crystallinity - 258, 363; macropores formed using latex spheres as templates -279 .

\subsubsection{Hydrophobic/Hydrophilic Surface Treatment}

Several approaches have been taken to modify the surface of titanium dioxide to modify the hydrophobicity:

Silica gel - 403, 499, 535, 720, 721; amphiphilic microfine titanium dioxide - 127;

superhydrophilicity $-222,733,782$; sunscreens $-269,368$; tethered organic compounds -610 ; Langmuir-Blodgett films - 659; silicones - 665, 715, 721, 722 .

\subsubsection{Dye Sensitized Titanium Dioxide}

Sensitizers have been used in conjunction with titanium dioxide to improve the response to visible light: ruthenium complexes $-68,75,141,183,334,386,435,567,682$; vanadium $(+5)$ complexes -69 , $70,71,226,227,501$; cobalt $(+2)$ complexes - no new reports; nickel $(+2)$ complexes - no new reports; copper $(+2)$ complexes - no new reports; cobalt $(+3)$ complexes $-69,70,226,227$; iron $(+2$ or +3$)-227,614,674$; metal phthalocyanine $-278,389,614,718$; porphyrins -131 , 450, 451; and organic dyes - 68, 259, 675, 697.

\subsubsection{Metal lon Doping of Titanium Dioxide or Mixed Oxides}

Other metal ions have been introduced into the titanium dioxide lattice to modify the properties. They are covered in the following:

$\mathrm{Li}-100,408 ; \mathrm{Mg}-611 ; \mathrm{Al}-14,100 ; \mathrm{Si}-14,197,343,479,820 ; \mathrm{V}-46,838 ; \mathrm{Cr}-30,100$, 247, 611, 723; Mn - 4; Fe - 89, 90, 100, 139, 140, 425, 526, 544, 578, 611, 613, 638, 658; Co 100, 611; $\mathrm{Zn}-100,139 ; \mathrm{La}-418 ; \mathrm{Zr}-179,839 ; \mathrm{Nb}-125,357$; Mo - no new reports; $\mathrm{Ru}-686$; $\mathrm{Ba}-408 ; \mathrm{La}-418 ; \mathrm{Ce}-100,316,418 ; \mathrm{W}-402,463 ; \mathrm{Pb}-790 ; \mathrm{Cd}-100$. 


\subsubsection{Metallized Titanium Dioxide}

Noble metals have been deposited on the titanium dioxide surface to enhance catalytic activity:

$\mathrm{Ni}-160,480 ; \mathrm{Cu}-383,480 ; \mathrm{Rh}$ - no new reports; $\mathrm{Pd}-361 ; \mathrm{Pt}-34,46,90,100,151,174,184$, 206, 324, 361, 422, 437, 464, 489, 496, 510, 543, 544, 561, 562, 638, 655, 660, 681, 723, 744, 759, 771, 823; Ag - 50, 139, 207, 262, 383, 438, 650, 744; Au - 181, 402, 774. Addition of metal powders $(\mathrm{Cu}, \mathrm{Ag}, \mathrm{Ni}$, or $\mathrm{Co})$ enhances some photocatalytic reactions -276 .

\subsubsection{Other Semiconductors}

A wide range of semiconductors and other materials has been tested for photocatalytic activity. They are generally less active than titanium dioxide. Relevant work is cited in the following:

$\mathrm{MgO}-603 ; \mathrm{Al}_{2} \mathrm{O}_{3}-590 ; \mathrm{SiC}-450 ; \mathrm{V}_{2} \mathrm{O}_{5}-46,313,833 ; \mathrm{Mn}_{2} \mathrm{O}_{3}-130 ; \mathrm{Fe}_{2} \mathrm{O}_{3}-59,61,187$, $325,500,590,836,856 ; \mathrm{FeTiO}_{3}-590 ; \mathrm{CO}_{3} \mathrm{O}_{4}-393 ; \mathrm{ZnO}-88,142,157,325,355,368,374$, $391,392,460,461,583,603,713,754,836,856$; Zn- or CdS - 47, 345, 391, 563, 627, 686, 754, 836, 856; $\mathrm{Pt} / \mathrm{CdS}$ - ; ZnTe - ; $\mathrm{ZrO}_{2}-279 ; \mathrm{ZrTiO}_{4}-525 ; \mathrm{MoS}_{2}-; \mathrm{SnO}_{2}-59,310 ; \mathrm{Sb}_{2} \mathrm{O}_{4}-$ no new reports; $\mathrm{SnO}_{2}-275,322,386 ; \mathrm{BaTiO}_{4} \mathrm{O}_{9}-408 ; \mathrm{CeO}_{2}$ - no new reports; $\mathrm{WO}_{3}-355,392$, 402, 523, 825; $\mathrm{Nb}_{2} \mathrm{O}_{5}-357,703,833 ; \mathrm{RuS}_{2}-664 ; \mathrm{Cs}_{3} \mathrm{PW}_{12} \mathrm{O}_{40}$; fly ash - 196, 590; furnace slag or core sands - 590; polyaniline - no new reports; poly(p-phenylene) - no new reports; polythiocyanogen - no new reports; clays - 193, 590; mica - 590; atmospheric aerosols - 325, 327 ; desert sand $-325,374,590$; volcanic ash -325 ; sea salt -325 ; chalk -325 ; or soot -325 .

\subsubsection{Immobilized Photocatalysts}

Most experimental work on aqueous systems has been performed using the photocatalyst in the form of fine particles suspended in the liquid phase. In a waste treatment application it would be simpler if the catalyst were immobilized in the photo reactor so the material would not have to be separated from the treated fluid in a subsequent process step. Most work for treating gases has been done with immobilized catalysts. Titanium dioxide has been affixed to a variety of surfaces: glass (including fibers, Pyrex, quartz, Vicor) - 85, 100, 134, 135, 137, 176, 185, 186, 222, 253, 262 , 294, 304, 311, 314, 315, 358, 412, 413, 469, 478, 496, 498, 509, 535, 545, 549, 551, 577, $578,579,600,601,602,620,621,622,623,624,655,658,681,693,707,708,722,739,752$, 778, 780, 781, 790, 791, 829; silica gel - 6,7, 198, 410, 464, 472, 473, 474, 484, 535, 653, 674, $698,699,726,783,831,832,833$; metal - 48, 107, 108, 251, 310, 314, 326, 478, 788; clays - no new reports; crysotile fibers - 765; organic polymer - 41, 223, 224, 296, 314, 522, 534, 650, 692, 759; thin films - 207, 208, 209, 210, 440, 441, 519, 520, 655, 713, 808, 809; internal light guide no new reports; zeolite $-27,34,35,36,39,143,312,313,726,727,783,811,812,813,818$, 819,847 ; alumina - 176, 410, 436, 726, 783; alumite - 470; carbon - 284, 468, 499, 609, 725, 726, 748, 750, 783, 828; membranes - 501; paper - 740; textiles - 751; Ambersorb - no new reports; PHOTOPERM ${ }^{\mathrm{TM}}-227$; metal oxides and ceramics - 46, 74, 107, 295, 310, 469, 503, $515,519,520,521,658,710,717,727,770,815$; vesicles and micelles - 386; slag - 289, 291, 292, 293; pellets - 822; or unspecified - 511, 512.

\subsection{Hydrogen Peroxide and Other Oxidants}

Oxygen is most common oxidant for photocatalytic reactions, but other oxidants have been found to improve reaction rates with a variety of organic substrates under some conditions. This work is covered in the following:

hydrogen peroxide - 59, 91, 137, 166, 236, 356, 374, 384, 508, 536, 538, 571, 573, 574, 590, 603 ; superoxide - ; peroxydisulfate $-453,454,508$; chlorite - no new reports; chlorate - no new 
reports; bromate $-422,423,589,508$; periodate - no new reports; nitrous oxide -713 ; or ozone 226, 460, 461, 584.

\subsection{Engineering Issues}

In recent years the success of laboratory work has led to interest in applying the technology to environmental remediation and treatment of process waste streams. Work in the literature addresses issues related to the scale-up of the process and resolution of engineering problems. Progress has been signifi- cant and some companies now provide turnkey systems for treating contaminated water and air. The largest market is for room air cleaners that are produced by companies in Japan exclusively for the Japanese market.

\subsubsection{Reactor and System Design}

Numerous papers have addressed topics relevant to the design of reactors for photocatalytic processes: photochemical reactors -11 ; non-concentrating reactor $-24,52,53,56,78,91,99,240,545,572$, $573,596,764,784,787$; parabolic trough $-23,56,59,91,96,97,228,229,346,453,454,462$, 570, 571, 572, 574, 607, 767, 768; compound parabolic concentrator - 263, 453, 454, 462, 478; kinetic modeling $-8,9,10,71,72,228,229,498,531,532,547,579,587,630,671,757,762$, 763; packed bed - 531; filtration - 691; controlled periodic illumination - 195, 377, 762; light scattering model $-8,9,10,99,109,110,579,619,635,672$; flat plate reactor $-52,53,56,59,78$, 99; ceramic monolith - 295, 532, 547, 717, 770; annular packed bed reactor - 619; mass transfer limitations - 577; photocatalytic membrane reactor $-69,71,226,227$; fiber optic cable reactor $535,549,577,578,579$; cocurrent downflow bubble column contactor - 98, 676, 798; two phase, swirl flow monolith reactor $-128,622$; ring roughened annular reactor - 303, 305; laminar falling film slurry reactor $-411,572,573$; shell and tube reactor $-620,623$; water bell reactor -673 ; air lift loop reactor $-687,688$; field tests $-53,97,151,240,263,280,462,570,571,572,573,574$, 591, 756; materials for solar reactors - 336, 388, 477, 478, 545, 577, 578, 579, 607, 797, 801; solar resource assessment - 483; or treatment system design -23, 24, 77, 78, 97, 237, 336, 346, $482,656,719$.

\subsubsection{Systems Analysis}

As the technology for photocatalytically treating contaminated air and water has progressed, some work on economic evaluation has appeared in the literature. New work is limited:

photon costs from lamps and sunlight $-80,755$; marketing study -25 ; solar processes $-230,238$, $346,478,596,755,797$; comparison of activated carbon with photocatalytic removal of air contaminants $-260,261,755$; process for controlling solvent emissions -446 .

\subsection{Miscellaneous Topics}

This category includes papers of interest that do not fall into the preceding headings: actinometry - no new reports; adsorption - 47, 102, 103, 151, 173, 174, 385, 394, 484, 566, 637, $671,694,720,725,726,769,783,799,813$; combined photocatalytic and biological treatment $93,94,120,163,167,168,249,264,265,415,601,602$; combined photocatalytic and ultrafiltration treatment -342 ; effect of applied voltage bias on photocatalytic reactions $-4,108$, $160,310,318,322,351,352,353,354,382,419,509,606,707,708,749$; non-aqueous solvent systems - 1, 49, 50, 87, 101, 121, 147, 513; applications in chemical analysis - 344, 535; polymer aging - 2, 12, 62, 391, 569; photo initiators - ; "inert" ion or molecule effect - 88, 203, 212, 243, $308,322,397,420,421,447,494,533,547,548,575,586,599,600,603,606,626,663,668$, 712, 756, 766, 778, 781, 845; dissolved metal ion effect - 384, 422, 423, 538, 555, 556, 590, 804, 845; comparison with other advanced oxidation processes - 169, 170, 249, 350, 580, 603, 605, $636,648,662,696,709,789$; purification of ultrapure water for recirculation - 129; clean room 
application $-213,214,215,521,747$; purification of drinking water - 350, 412, 413, 795; municipal wastewater - 414; process wastewater - 81, 82, 83, 84, 199, 455, 456, 462, 492, 538, 596, 601, 602, 830, 853; paper mill effluent - 460, 461, 583, 584, 585; organic synthesis - 1, 49, $50,87,101,121,557,558,563,564,666,690,706,754,777,833$; surface science of $\mathrm{TiO}_{2}-131$, $161,194,487,504,505,506,512,637,659$; solid state NMR - 309, 608; quantum yield as a function of particle size and/or light intensity - 109, 111, 552, 553, 554, 671, 693, 703, 775; indoor air quality applications - 239, 328, 329, 656, 698, 699; light flux dependence - 11, 45, 64, $111,151,195,246,283,552,553,554,571,572,574,594,624,685,763$; light source effects $286,400,488,603,620,621,624,643,649,652,705,784,794,814$; temperature effects on photocatalytic oxidation - 46, 347, 348, 496, 564, 572; photoconductivity/ electrical conductivity - 370; imaging applications - 406, 479, 480, 481, 642; Dember effect - 404; self-cleaning surface - 280, 335, 782; ultrasound enhancement $-44,337,657,700$; mixed waste $-593,594,595,596$; catalyst lifetime $-43,138,151,169,484,582,586,627,752$; treatment of photographic processing effluents -724 ; point of zero charge determination - 189, 586; electrorheology - 618; computer modeling - 246, 288; mechanism and intermediates - 275, 466, 467, 484, 533, 541, $554,561,562,563,580,583,584,585,626,638,646,659,686,701,741,742,749,752,757$, $762,772,773,811,812,850$; formation of hydroxyl radicals over metal oxides $-266,517,536$, $638,664,757$; formulation of photocatalytic paint - 296, 569, 692 .

\subsection{Patents}

The number of patents that cover aspects of photocatalytic technology is increasing rapidly. This report includes 660 that have appeared since the last update. They cover a range of aqueous, gas-phase, and surface cleaning applications. The new patents are listed separately in Section 5.2.

\subsection{Companies Active in the Field}

$\mathrm{R} \& \mathrm{D}$ and market assessment activities are underway at many companies in the United States, but there is little change in the list of companies that have started business lines that use photocatalytic processes. ${ }^{3}$ Japanese companies are very aggressively commercializing applications of titanium dioxide catalysts, films, and coatings. These products have not yet begun to appear in the U.S. market. 


\subsection{Compounds Studied}

The tables in this section have the same format as in the first two reports. No compounds have been removed from the tables, but new compounds have been added to the second table to incorporate new work. The list of the compounds included in various lists of priority pollutants, air toxics, and the toxic release inventory compiled by the $\mathrm{EPA}^{4}$ provided the starting point for these tables. Table 1 lists compounds in the EPA categories; Table 2 lists organic compounds that are not in Table 1; and Table 3 covers inorganic compounds that have been treated by a photocatalytic process. The inorganic compounds are arranged by element unless a significant number of citations referred to work on a specific ion or compound. A few broad categories are included in Table 2 that reflect new applications: bacteria, algae, and viruses; coal or carbon; adsorbable organic halides (AOX); color or chemical oxygen demand (COD); and oil or petroleum, for example. In these tables the citation suffix " $\mathrm{g}$ " indicates a gas-phase study. The treatability of compounds that have not been tested can usually be inferred from results for related compounds in the tables.

Table 1. Organic Compounds in EPA Lists of Priority Pollutants, Air Toxics, or Toxic Release Inventory

\begin{tabular}{|c|c|c|}
\hline Substance & Formula & Reference \\
\hline 1,1,1-Trichloroethane & $\mathrm{CHCl}_{2} \mathrm{CH}_{2} \mathrm{Cl}$ & $\begin{array}{l}\mathrm{g} 154, \mathrm{~g} 155, \mathrm{~g} 325,466,467, \\
571,574\end{array}$ \\
\hline 1,1,2,2-Tetrachloroethane & $\mathrm{CHCl}_{2} \mathrm{CHCl}_{2}$ & \\
\hline 1,1,2-Trichloroethane & $\mathrm{CHCl}_{2} \mathrm{CH}_{2} \mathrm{Cl}$ & \\
\hline 1,1,2-Trichloro-1,2,2-trifluoroethane & $\mathrm{CCl}_{2} \mathrm{FCCIF}_{2}$ & \\
\hline 1,1-Dichloroethane & $\mathrm{CH}_{3} \mathrm{CHCl}_{2}$ & \\
\hline 1,1-Dimethyl hydrazine & $\left(\mathrm{CH}_{3}\right)_{2} \mathrm{NNH}_{2}$ & \\
\hline 1,2,3-Trichloropropane & $\mathrm{CH}_{2} \mathrm{ClCHClCH}{ }_{2} \mathrm{Cl}$ & \\
\hline 1,2,4-Trichlorobenzene & $\mathrm{C}_{6} \mathrm{H}_{3} \mathrm{C}_{13}$ & 759 \\
\hline 1,2,4-Trimethylbenzene & $\mathrm{C}_{6} \mathrm{H}_{3}\left(\mathrm{CH}_{3}\right)_{3}$ & \\
\hline 1,2-Butylene oxide & $\mathrm{H}_{2} \mathrm{COCHCH}_{2} \mathrm{CH}_{3}$ & \\
\hline 1,2-Dibromoethane & $\mathrm{BrCH}_{2} \mathrm{CH}_{2} \mathrm{Br}$ & \\
\hline 1,2-Dibromo-3-chloropropane (DBCP) & $\mathrm{CH}_{2} \mathrm{BrCHBrCH}_{2} \mathrm{Cl}$ & \\
\hline 1,2-Dichlorobenzene & $\mathrm{C}_{6} \mathrm{H}_{4} \mathrm{Cl}_{2}$ & 705 \\
\hline 1,2-Dichloroethane & $\mathrm{ClCH}_{2} \mathrm{CH}_{2} \mathrm{Cl}$ & 657 \\
\hline 1,2-Dichloroethylene & $\mathrm{ClHC:} \mathrm{CHCl}$ & \\
\hline 1,2-Dichloropropane & $\mathrm{CH}_{3} \mathrm{CHClCH}_{2} \mathrm{Cl}$ & \\
\hline 1,2-Dinitrotoluene & $\mathrm{C}_{6} \mathrm{H}_{3} \mathrm{CH}_{3}\left(\mathrm{NO}_{2}\right)_{2}$ & \\
\hline 1,2-Diphenylhydrazine & $\mathrm{C}_{12} \mathrm{H}_{12} \mathrm{~N}_{2}$ & \\
\hline 1,2-Trans-dichloroethene & $\mathrm{C}_{2} \mathrm{H}_{2} \mathrm{Cl}_{2}$ & \\
\hline 1,3,5-Trinitrobenzene & $\mathrm{C}_{6} \mathrm{H}_{3}\left(\mathrm{NO}_{2}\right)_{3}$ & \\
\hline 1,3-Butadiene & $\mathrm{H}_{2} \mathrm{C}: \mathrm{CHHC}: \mathrm{CH}_{2}$ & \\
\hline 1,3-Dichlorobenzene & $\mathrm{C}_{6} \mathrm{H}_{4} \mathrm{Cl}$ & \\
\hline 1,3-Dichloropropene & $\mathrm{CHCl}: \mathrm{CHCH}_{2} \mathrm{Cl}$ & \\
\hline 1,4-Dichlorobenzene & $\mathrm{C}_{6} \mathrm{H}_{4} \mathrm{Cl}_{2}$ & 150 \\
\hline
\end{tabular}

\footnotetext{
4 "Notice of the Second Priority List of Hazardous Substances Commonly Found at Superfund Sites," Environmental Reporter, October 28, 1988, pp. 1255-1260.
} 
Table 1. Organic Compounds in EPA Lists of Priority Pollutants, Air Toxics, or Toxic Release Inventory

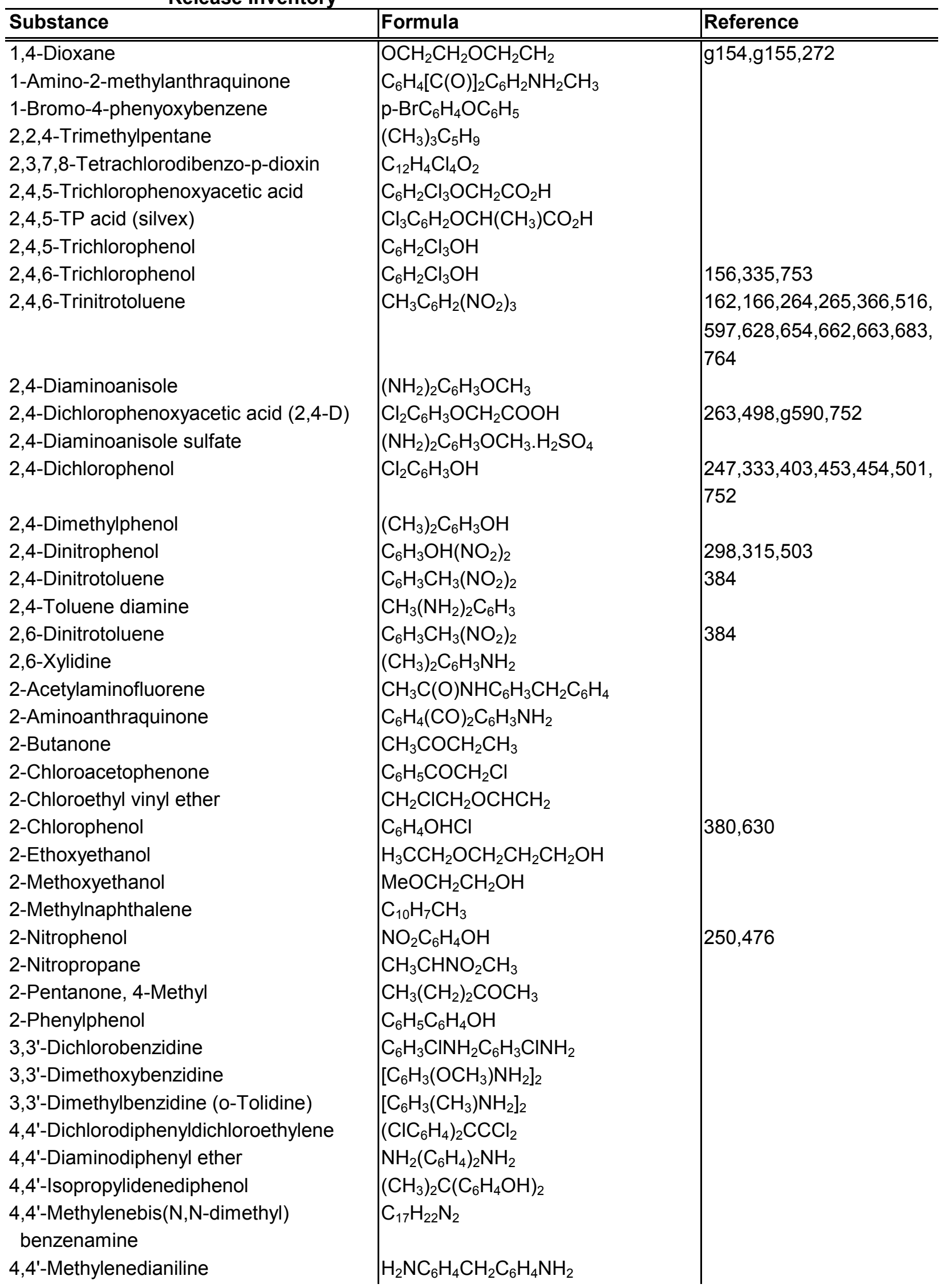


Table 1. Organic Compounds in EPA Lists of Priority Pollutants, Air Toxics, or Toxic Release Inventory

\begin{tabular}{|c|c|c|}
\hline Substance & Formula & Reference \\
\hline $\begin{array}{l}4,4 \text { '-Methylene-bis-(2-chloroaniline) } \\
\end{array}$ & $\mathrm{CH}_{2}\left(\mathrm{C}_{6} \mathrm{H}_{4} \mathrm{CINH}_{2}\right)_{2}$ & \\
\hline 4,4'-Thiodianiline & $\mathrm{C}_{12} \mathrm{H}_{12} \mathrm{~N}_{2} \mathrm{~S}$ & \\
\hline 4,6-Dinitro-o-cresol & $\mathrm{CH}_{3} \mathrm{C}_{6} \mathrm{H}_{2}\left(\mathrm{NO}_{2}\right)_{2} \mathrm{OH}$ & \\
\hline 4,6-Dinitro-2-methylphenol & $\mathrm{C}_{7} \mathrm{H}_{6} \mathrm{~N}_{2} \mathrm{O}_{5}$ & \\
\hline 4-Aminoazobenzene & $\mathrm{C}_{6} \mathrm{H}_{5} \mathrm{NNC}_{6} \mathrm{H}_{4} \mathrm{NH}_{2}$ & \\
\hline 4-Aminobiphenyl & $\mathrm{C}_{6} \mathrm{H}_{5} \mathrm{C}_{6} \mathrm{H}_{4} \mathrm{NH}_{2}$ & \\
\hline 4-Chloroaniline & $\mathrm{ClC}_{6} \mathrm{H}_{4} \mathrm{NH}_{2}$ & 275 \\
\hline 4-Chlorophenyl phenyl ether & $\mathrm{p}-\mathrm{ClC}_{6} \mathrm{H}_{4} \mathrm{OC}_{6} \mathrm{H}_{5}$ & \\
\hline 4-Dimethylaminoazobenzene & $\left(\mathrm{CH}_{3}\right)_{2} \mathrm{C}_{6} \mathrm{H}_{3} \mathrm{NH}_{2}$ & \\
\hline 4-Methylphenol & $\mathrm{p}-\mathrm{CH}_{3} \mathrm{C}_{6} \mathrm{H}_{4} \mathrm{OH}$ & \\
\hline 4-Nitrobiphenyl & $\mathrm{C}_{6} \mathrm{H}_{5} \mathrm{C}_{6} \mathrm{H}_{4} \mathrm{NO}_{2}$ & \\
\hline 4-Nitrophenol & $\mathrm{NO}_{2} \mathrm{C}_{6} \mathrm{H}_{4} \mathrm{OH}$ & $\begin{array}{l}101,128,190,191,192,436 \\
463,476,625,761,779\end{array}$ \\
\hline 5-Nitro-o-anisidine & $\mathrm{NO}_{2} \mathrm{C}_{6} \mathrm{H}_{3}\left(\mathrm{NH}_{2}\right)\left(\mathrm{OCH}_{3}\right)$ & \\
\hline Acenaphthene & $\mathrm{C}_{10} \mathrm{H}_{6}\left(\mathrm{CH}_{2}\right)_{2}$ & \\
\hline Acenaphthylene & $\mathrm{C}_{12} \mathrm{H}_{8}$ & \\
\hline Acetaldehyde & $\mathrm{CH}_{3} \mathrm{CHO}$ & $\begin{array}{l}\text { g41,g154,g155,g184,318, } \\
\text { g363,g470,g504,g505, } \\
\text { g506,g537,g554,g645, } \\
649, g 692, g 693, g 698, \\
\text { g699,g717,g737,g770, } \\
\text { g771,g832,g841 }\end{array}$ \\
\hline Acetamide & $\mathrm{CH}_{3} \mathrm{CNOH}_{2}$ & \\
\hline Acetone & $\mathrm{CH}_{3} \mathrm{COCH}_{3}$ & $\begin{array}{l}\text { g17,g154,g155,g172, } \\
\text { g418,g511,g512,g698, } \\
\text { g699, g737,g770,g771, } \\
\text { g832, 838,g839 }\end{array}$ \\
\hline Acetonitrile & $\mathrm{CH}_{3} \mathrm{CN}$ & \\
\hline Acetophenone & $\mathrm{CH}_{3} \mathrm{C}(\mathrm{O}) \mathrm{C}_{6} \mathrm{H}_{5}$ & \\
\hline Acrolein & $\mathrm{CH}_{2} \mathrm{CHCHO}$ & \\
\hline Acrylamide & $\mathrm{CH}_{2} \mathrm{CHCONH}_{2}$ & \\
\hline Acrylic acid & $\mathrm{H}_{2} \mathrm{C}: \mathrm{CHCOOH}$ & \\
\hline Acrylonitrile & $\mathrm{H}_{2} \mathrm{C}: \mathrm{CHCN}$ & \\
\hline Aldrin & $\mathrm{C}_{12} \mathrm{H}_{8} \mathrm{Cl}_{6}$ & \\
\hline Allyl chloride & $\mathrm{H}_{2} \mathrm{CCHCH}_{2} \mathrm{Cl}$ & \\
\hline Aniline & $\mathrm{C}_{6} \mathrm{H}_{5} \mathrm{NH}_{2}$ & $275,588,589,600,614,651$ \\
\hline Anthracene & $\mathrm{C}_{6} \mathrm{H}_{4}(\mathrm{CH})_{2} \mathrm{C}_{6} \mathrm{H}_{4}$ & 741 \\
\hline Aramite & $\begin{array}{l}\left(\mathrm{CH}_{3}\right)_{3} \mathrm{CC}_{6} \mathrm{H}_{4} \mathrm{OCH} \mathrm{H}_{2} \mathrm{CH}\left(\mathrm{CH}_{3}\right)^{-} \\
\quad \mathrm{SO}_{3} \mathrm{C}_{2} \mathrm{H}_{4} \mathrm{Cl}\end{array}$ & \\
\hline Atrazine & $\mathrm{C}_{18} \mathrm{H}_{14} \mathrm{CIN}_{5}$ & $226,307,462,501$ \\
\hline Benzal chloride & $\mathrm{C}_{6} \mathrm{H}_{5} \mathrm{CHCl}_{2}$ & \\
\hline Benzamide & $\mathrm{C}_{6} \mathrm{H}_{5} \mathrm{CONH}_{2}$ & \\
\hline Benzene & $\mathrm{C}_{6} \mathrm{H}_{6}$ & $\begin{array}{l}\text { 149,151,g154,g155,240, } \\
\text { g244,g325,g329,g394, } \\
\text { g417,g639,756,g824 }\end{array}$ \\
\hline
\end{tabular}


Table 1. Organic Compounds in EPA Lists of Priority Pollutants, Air Toxics, or Toxic Release Inventory

\begin{tabular}{|c|c|c|}
\hline Substance & Formula & Reference \\
\hline Benzidine & $\mathrm{NH}_{2}\left(\mathrm{C}_{6} \mathrm{H}_{4}\right)_{2} \mathrm{NH}_{2}$ & \\
\hline Benzoic acid & $\mathrm{C}_{6} \mathrm{H}_{5} \mathrm{COOH}$ & \\
\hline Benzoic trichloride & $\mathrm{C}_{6} \mathrm{H}_{5} \mathrm{CCl}_{3}$ & \\
\hline Benzoyl chloride & $\mathrm{C}_{6} \mathrm{H}_{5} \mathrm{COCl}$ & \\
\hline Benzoyl peroxide & $\left(\mathrm{C}_{6} \mathrm{H}_{5} \mathrm{CO}\right)_{2} \mathrm{O}_{2}$ & \\
\hline Benzo(a)anthracene & $\mathrm{C}_{22} \mathrm{H}_{14}$ & \\
\hline Benzo(a)pyrene & $\mathrm{C}_{20} \mathrm{H}_{12}$ & \\
\hline Benzo(b)fluoranthene & $\mathrm{C}_{20} \mathrm{H}_{12}$ & \\
\hline Benzo(g,h,i) perylene & $\mathrm{C}_{22} \mathrm{H}_{12}$ & \\
\hline Benzyl alcohol & $\mathrm{C}_{6} \mathrm{H}_{5} \mathrm{CH}_{2} \mathrm{OH}$ & g394 \\
\hline Benzyl chloride & $\mathrm{C}_{6} \mathrm{H}_{5} \mathrm{CH}_{2} \mathrm{Cl}$ & \\
\hline BHC (Benzenehexachloride) & $\mathrm{C}_{6} \mathrm{H}_{6} \mathrm{Cl}_{6}$ & \\
\hline Biphenyl & $\mathrm{C}_{6} \mathrm{H}_{5} \mathrm{C}_{6} \mathrm{H}_{5}$ & \\
\hline Bis(2-Chloroethoxy)methane & $\mathrm{CH}_{2}\left(2-\mathrm{ClC}_{2} \mathrm{H}_{5} \mathrm{O}\right)_{2}$ & \\
\hline Bis(2-chloroethyl) ether & $\mathrm{ClCH}_{2} \mathrm{CH}_{2} \mathrm{OCH}_{2} \mathrm{CH}_{2} \mathrm{Cl}$ & \\
\hline Bis(2-chloro-1-methylethyl) ether & {$\left[\mathrm{ClCH}_{2}\left(\mathrm{CH}_{3}\right) \mathrm{CH}\right]_{2} \mathrm{O}$} & \\
\hline Bis(2-ethylhexyl) adipate & $\left(\mathrm{C}_{7} \mathrm{H}_{13}\right)_{2} \mathrm{C}_{4} \mathrm{H}_{8}\left(\mathrm{CO}_{2}\right)_{2}$ & \\
\hline Bis(2-ethylhexyl)phthalate & $\left(\mathrm{C}_{4} \mathrm{H}_{9} \mathrm{CH}\left(\mathrm{CH}_{2}\right)\right)_{2} \mathrm{OOC}$ & \\
\hline Bis(chloromethyl)ether & $\left(\mathrm{CH}_{2} \mathrm{Cl}\right) \mathrm{O}\left(\mathrm{CH}_{2} \mathrm{Cl}\right)$ & \\
\hline Bromochloromethane & $\mathrm{BrCH}_{2} \mathrm{Cl}$ & \\
\hline Bromodichloromethane & $\mathrm{CHCl}_{2} \mathrm{Br}$ & \\
\hline Bromoethane & $\mathrm{C}_{2} \mathrm{H}_{5} \mathrm{Br}$ & \\
\hline Bromoform (Tribromomethane) & $\mathrm{CHBr}_{3}$ & 145,146 \\
\hline Bromomethane (Methyl bromide) & $\mathrm{CH}_{3} \mathrm{Br}$ & \\
\hline Butyl acrylate & $\mathrm{CH}_{2}: \mathrm{CHCOOC}_{4} \mathrm{H}_{9}$ & \\
\hline Butylbenzyl phthalate & $\mathrm{C}_{4} \mathrm{H}_{9} \mathrm{OOCC}_{6} \mathrm{H}_{4} \mathrm{COOC}_{7} \mathrm{H}_{7}$ & \\
\hline Butyraldehyde & $\mathrm{CH}_{3}\left(\mathrm{CH}_{2}\right)_{2} \mathrm{CHO}$ & g154,g155 \\
\hline Calcium cyanamide & $\mathrm{NCNCa}$ & \\
\hline Caprolactam & $\mathrm{CH}_{2}\left(\mathrm{CH}_{2}\right)_{4} \mathrm{NHCO}$ & \\
\hline $\begin{array}{l}\text { Captan (N-Trichloromethylmercapto- } \\
\text { tetrahydrophthalimide) }\end{array}$ & $\mathrm{C}_{9} \mathrm{H}_{8} \mathrm{Cl}_{3} \mathrm{NO}_{2} \mathrm{~S}$ & \\
\hline $\begin{array}{l}\text { Carbaryl [1-Naphthalenol, } \\
\text { methylcarbamate] }\end{array}$ & $\mathrm{C}_{10} \mathrm{H}_{7} \mathrm{OOCNHCH}_{3}$ & 598 \\
\hline Carbon disulfide & $\mathrm{CS}_{2}$ & \\
\hline Carbon tetrachloride & $\mathrm{CCl}_{4}$ & $\begin{array}{l}116,141,145,146,271 \\
g 325,465,570,574,791\end{array}$ \\
\hline Carbonyl sulfide & cos & \\
\hline Catechol & $\mathrm{C}_{6} \mathrm{H}_{4}(\mathrm{OH})_{2}$ & \\
\hline $\begin{array}{l}\text { Chloramben (Benzoic acid, 3-amino-2, } \\
\text { 5-dichloro-) }\end{array}$ & $\mathrm{C}_{6} \mathrm{H}\left(\mathrm{CO}_{2} \mathrm{H}\right)\left(\mathrm{NH}_{2}\right) \mathrm{Cl}_{2}$ & \\
\hline Chlordane & $\mathrm{C}_{10} \mathrm{H}_{6} \mathrm{Cl}_{8}$ & \\
\hline Chloroacetic acid & $\mathrm{CH}_{2} \mathrm{ClCOOH}$ & 227,731 \\
\hline Chlorobenzene & $\mathrm{C}_{6} \mathrm{H}_{5} \mathrm{Cl}$ & g464 \\
\hline $\begin{array}{l}\text { Chlorobenzilate (Benzeneacetic acid, } \\
\text { 4-chloro-alpha-(4-chlorophenyl)-) }\end{array}$ & $\left(\mathrm{C}_{6} \mathrm{H}_{4} \mathrm{Cl}\right)_{2} \mathrm{C}(\mathrm{OH}) \mathrm{COOC}_{2} \mathrm{H}_{5}$ & \\
\hline
\end{tabular}


Table 1. Organic Compounds in EPA Lists of Priority Pollutants, Air Toxics, or Toxic Release Inventory

\begin{tabular}{|c|c|c|}
\hline Substance & Formula & Reference \\
\hline Chlorodibenzodioxins, various & $\mathrm{C}_{12} \mathrm{O}_{2} \mathrm{H}_{8-\mathrm{x}} \mathrm{Cl}_{\mathrm{x}}$ & \\
\hline Chlorodibenzofurans & $\mathrm{C}_{12} \mathrm{OH}_{8-\mathrm{x}} \mathrm{Cl}_{\mathrm{x}}$ & \\
\hline Chlorodibromomethane & $\mathrm{ClBr}_{2} \mathrm{CH}$ & \\
\hline Chlorodifluoromethane & $\mathrm{CHClF}_{2}$ & \\
\hline Chloroethane & $\mathrm{C}_{2} \mathrm{H}_{5} \mathrm{Cl}$ & \\
\hline Chloroform & $\mathrm{CHCl}_{3}$ & $\begin{array}{l}\text { g5,116,139,145,146,g154, } \\
\text { g155,g305,g325,465,493, } \\
570,574,736,775,791\end{array}$ \\
\hline Chloromethane & $\mathrm{CH}_{3} \mathrm{Cl}$ & \\
\hline Chloromethyl methyl ether & $\mathrm{C}_{2} \mathrm{H}_{5} \mathrm{ClO}$ & \\
\hline Chloroprene & $\mathrm{H}_{2} \mathrm{C}: \mathrm{CHCCl}: \mathrm{CH}_{2}$ & \\
\hline $\begin{array}{l}\text { Chlorothalonil (1,3-Benzendedicarboni- } \\
\text { trile, 2,4,5,6-tetrachloro-) }\end{array}$ & $\mathrm{C}_{6} \mathrm{Cl}_{4}(\mathrm{CN})_{2}$ & \\
\hline Chrysene & $\mathrm{C}_{18} \mathrm{H}_{12}$ & \\
\hline cis-1,2-Dichloroethylene & $\mathrm{ClHC}: \mathrm{CHCl}$ & \\
\hline cis-1,3-Dichloropropene & $\mathrm{CHCl}: \mathrm{CHCH}_{2} \mathrm{Cl}$ & \\
\hline o-,m-,p-Cresols & $\mathrm{CH}_{3} \mathrm{C}_{6} \mathrm{H}_{4} \mathrm{OH}$ & g395,601,602,761,779 \\
\hline Cumene & $\mathrm{C}_{6} \mathrm{H}_{5} \mathrm{CH}\left(\mathrm{CH}_{3}\right)_{2}$ & g325,799 \\
\hline Cumene hydroperoxide & $\mathrm{C}_{6} \mathrm{H}_{5} \mathrm{C}\left(\mathrm{CH}_{3}\right)_{2} \mathrm{OOH}$ & \\
\hline $\begin{array}{l}\text { Cupferron (Benzeneamine, N-hydroxy- } \\
\text { N-nitrose, ammonium salt) }\end{array}$ & $\mathrm{C}_{6} \mathrm{H}_{5} \mathrm{~N}(\mathrm{NO}) \mathrm{ONH}_{4}$ & \\
\hline Cyclohexane & $\mathrm{C}_{6} \mathrm{H}_{12}$ & 409,706 \\
\hline Cyclohexanone & $\mathrm{C}_{6} \mathrm{H} 10 \mathrm{O}$ & \\
\hline Cyclonite (RDX) & $\left(\mathrm{CH}_{2}\right)_{3}\left(\mathrm{NNO}_{2}\right)_{3}$ & 597,683 \\
\hline Decabromodiphenyl oxide & $\left(\mathrm{C}_{6} \mathrm{Br}_{5}\right)_{2} \mathrm{O}$ & \\
\hline $\begin{array}{l}\text { Dialate [Carbamothioic acid, bis } \\
\text { (1-methylethyl)-, S-(2,3- } \\
\text { dichloro-2-propenyl) ester] }\end{array}$ & {$\left[\left(\mathrm{CH}_{3}\right)_{2} \mathrm{CH}\right]_{2} \mathrm{NCOSCH}_{2} \mathrm{CClCHCl}$} & \\
\hline Diaminotoluene (mixed isomers) & $\mathrm{CH}_{3} \mathrm{C}_{6} \mathrm{H}_{3}\left(\mathrm{NH}_{2}\right)_{2}$ & \\
\hline Diazomethane & $\mathrm{CH}_{2} \mathrm{~N}_{2}$ & \\
\hline Dibenzofuran & $\mathrm{C}_{12} \mathrm{H}_{8} \mathrm{O}$ & \\
\hline Dibenzo(a,h)anthracene & $\mathrm{C}_{22} \mathrm{H}_{14}$ & \\
\hline Dibromochloropropane & $\mathrm{CH}_{2} \mathrm{BrCHBrCH}_{2} \mathrm{Cl}$ & \\
\hline Dibutyl phthalate & $\mathrm{C}_{6} \mathrm{H}_{4}\left(\mathrm{COOC}_{4} \mathrm{H}_{9}\right)_{2}$ & \\
\hline Dichlorobenzene (mixed isomers) & $\mathrm{C}_{6} \mathrm{H}_{4} \mathrm{Cl}_{2}$ & \\
\hline Dichlorobromomethane & $\mathrm{CHBrCl}_{2}$ & \\
\hline Dichlorodifluoromethane & $\mathrm{CCl}_{2} \mathrm{~F}_{2}$ & \\
\hline $\begin{array}{l}\text { Dichlorvos (Phosphoric acid, 2- } \\
\text { dichloroethenyl dimethyl ester) }\end{array}$ & $\left(\mathrm{CH}_{3} \mathrm{O}\right)_{2} \mathrm{P}(\mathrm{O}) \mathrm{OCH}: \mathrm{CCl}_{2}$ & $135,136,137,138,254,790$ \\
\hline $\begin{array}{l}\text { Dicofol (4,4'-Dichloro-alpha-trichloro- } \\
\text { Methylbenzhydrol) }\end{array}$ & $\mathrm{C}_{14} \mathrm{H}_{9} \mathrm{Cl}_{5} \mathrm{O}$ & \\
\hline Dieldrin/aldrin & $\mathrm{C}_{12} \mathrm{H}_{10} \mathrm{OPCl} \mathrm{I}_{6}$ & \\
\hline Diepoxybutane & $\mathrm{C}_{4} \mathrm{H}_{6} \mathrm{O}_{2}$ & \\
\hline Diethanolamine & $\left(\mathrm{HOCH}_{2} \mathrm{CH}_{2}\right)_{2} \mathrm{NH}$ & \\
\hline Diethyl phthalate & $\mathrm{C}_{6} \mathrm{H}_{4}\left(\mathrm{CO}_{2} \mathrm{C}_{2} \mathrm{H}_{5}\right)_{2}$ & 508 \\
\hline
\end{tabular}


Table 1. Organic Compounds in EPA Lists of Priority Pollutants, Air Toxics, or Toxic Release Inventory

\begin{tabular}{|c|c|c|}
\hline Substance & Formula & Reference \\
\hline $\begin{array}{l}\text { Diethyl sulfate } \\
\text { nat }\end{array}$ & $\left(\mathrm{C}_{2} \mathrm{H}_{5}\right)_{2} \mathrm{SO}_{4}$ & \\
\hline Dimethyl aminoazobenzene & $\mathrm{C}_{6} \mathrm{H}_{5} \mathrm{NNC}_{6} \mathrm{H}_{4} \mathrm{~N}\left(\mathrm{CH}_{3}\right)_{2}$ & \\
\hline Dimethyl formamide (DMF) & $\mathrm{HCON}\left(\mathrm{CH}_{3}\right)_{2}$ & \\
\hline Dimethyl phthalate & $\mathrm{C}_{6} \mathrm{H}_{4}\left(\mathrm{COOCH}_{3}\right)_{2}$ & \\
\hline Dimethyl sulfate & $\left(\mathrm{CH}_{3}\right)_{2} \mathrm{SO}_{4}$ & \\
\hline Dimethylcarbamyl chloride & $\left(\mathrm{CH}_{3}\right)_{2} \mathrm{NCOCl}$ & \\
\hline Disulfoton & $\left(\mathrm{C}_{2} \mathrm{H}_{5} \mathrm{O}\right)_{2} \mathrm{P}(\mathrm{S}) \mathrm{SCH}_{2} \mathrm{CH}_{2} \mathrm{SCH}_{2} \mathrm{CH}_{3}$ & \\
\hline Di-n-butyl phthalate & $\mathrm{C}_{6} \mathrm{H}_{4}\left(\mathrm{COOC}_{4} \mathrm{H}_{9}\right)_{2}$ & \\
\hline Di-n-octyl phthalate & $\mathrm{C}_{6} \mathrm{H}_{4}\left(\mathrm{CO}_{2}\right)\left(\mathrm{n}-\mathrm{C}_{8} \mathrm{H}_{17}\right)_{2}$ & g213,g214,g215,287 \\
\hline Di-(2-ethylhexy) phthalate (DEHP) & $\mathrm{C}_{6} \mathrm{H}_{4}\left[\mathrm{COOCH}_{2} \mathrm{CH}\left(\mathrm{C}_{2} \mathrm{H}_{5}\right) \mathrm{C}_{4} \mathrm{H}_{9}\right]_{2}$ & \\
\hline Endosulfan & $\mathrm{C}_{9} \mathrm{H}_{6} \mathrm{Cl}_{6} \mathrm{O}_{3} \mathrm{~S}$ & \\
\hline Endrin aldehyde/ endrin & $\left(\mathrm{C}_{12} \mathrm{H}_{8} \mathrm{OCl}_{6}\right)$ & \\
\hline Epichlorohydrin & $\mathrm{CH}_{2} \mathrm{OCHCH} \mathrm{Cl}_{2}$ & \\
\hline Ethyl acrylate & $\mathrm{CH}_{2}: \mathrm{CHCOOC}_{2} \mathrm{H}_{5}$ & \\
\hline Ethyl chloroformate & $\mathrm{ClCOOC}_{2} \mathrm{H}_{5}$ & \\
\hline Ethylbenzene & $\mathrm{C}_{6} \mathrm{H}_{5} \mathrm{C}_{2} \mathrm{H}_{5}$ & $\begin{array}{l}\text { 134,149,151,g154,g155, } \\
\mathrm{g} 213, \mathrm{~g} 214, \mathrm{~g} 215,240 \\
\mathrm{~g} 325,767,768\end{array}$ \\
\hline Ethylene & $\mathrm{H}_{2} \mathrm{C}: \mathrm{CH}_{2}$ & $\mathrm{~g} 17, \mathrm{~g} 206, \mathrm{~g} 548, \mathrm{~g} 680$ \\
\hline Ethylene glycol & $\mathrm{CH}_{2} \mathrm{OHCH}{ }_{2} \mathrm{OH}$ & 361 \\
\hline Ethylene oxide & $\mathrm{CH}_{2} \mathrm{CH}_{2} \mathrm{O}$ & \\
\hline Ethylene thiourea & $\mathrm{NHCH}_{2} \mathrm{CH}_{2} \mathrm{NHCS}$ & \\
\hline Ethyleneimine (Aziridine) & $\mathrm{CH}_{2} \mathrm{NHCH}_{2}$ & \\
\hline $\begin{array}{l}\text { Fluometuron [Urea, N,N-dimethyl-N'-[3- } \\
\text { (trifluoromethyl)phenyl]-] }\end{array}$ & $\mathrm{C}_{10} \mathrm{H}_{11} \mathrm{~F}_{3} \mathrm{~N}_{2} \mathrm{O}$ & \\
\hline Fluoranthene & $\mathrm{C}_{16} \mathrm{H}_{10}$ & \\
\hline Fluorene & $\mathrm{C}_{6} \mathrm{H}_{4} \mathrm{CH}_{2} \mathrm{C}_{6} \mathrm{H}_{4}$ & \\
\hline Fluorotrichloromethane & $\mathrm{CCl}_{3} \mathrm{~F}$ & \\
\hline Formaldehyde & $\mathrm{HCHO}$ & $\begin{array}{l}\text { g18,419,g537,g547,g698, } \\
\text { g699,850 }\end{array}$ \\
\hline Heptachlor/heptachlor epoxide & $\mathrm{C}_{10} \mathrm{H}_{7} \mathrm{Cl}_{7}$ & \\
\hline Heptane & $\mathrm{CH}_{3}\left(\mathrm{CH}_{2}\right)_{5} \mathrm{CH}_{3}$ & \\
\hline Hexachlorobenzene & $\mathrm{C}_{6} \mathrm{Cl}_{6}$ & \\
\hline Hexachlorobutadiene & $\mathrm{Cl}_{2} \mathrm{C}: \mathrm{CClCCl}: \mathrm{CCl}_{2}$ & \\
\hline Hexachlorocyclopentadiene & $\mathrm{C}_{5} \mathrm{Cl}_{6}$ & \\
\hline Hexachloroethane & $\mathrm{Cl}_{3} \mathrm{CCCl}_{3}$ & \\
\hline Hexachloronaphthalene & $\mathrm{C}_{10} \mathrm{H}_{2} \mathrm{Cl}_{6}$ & \\
\hline Hexamethylphosphoramide & {$\left[\left(\mathrm{N}\left(\mathrm{CH}_{3}\right)_{2}\right]_{3} \mathrm{PO}\right.$} & \\
\hline Hexamethylene-1,6-diisocyanate & $\mathrm{OCN}\left(\mathrm{CH}_{2}\right)_{6} \mathrm{NCO}$ & \\
\hline Hexane & $\mathrm{CH}_{3}\left(\mathrm{CH}_{2}\right)_{4} \mathrm{CH}_{3}$ & $g 154, g 155$ \\
\hline Hydroquinone & $\mathrm{C}_{6} \mathrm{H}_{4}(\mathrm{OH})_{2}$ & 250,278 \\
\hline Indeno(1,2,3-cd)pyrene & $\mathrm{C}_{22} \mathrm{H}_{12}$ & \\
\hline Isophorone & $\mathrm{C}(\mathrm{O}) \mathrm{CHC}\left(\mathrm{CH}_{3}\right) \mathrm{CH}_{2} \mathrm{C}\left(\mathrm{CH}_{3}\right)_{2} \mathrm{CH}_{2}$ & \\
\hline Isopropyl alcohol & $\left(\mathrm{CH}_{3}\right)_{2} \mathrm{CHOH}$ & $\begin{array}{l}\text { g102,g103,130,190,191, } \\
192,253,311,337,341,397\end{array}$ \\
\hline
\end{tabular}


Table 1. Organic Compounds in EPA Lists of Priority Pollutants, Air Toxics, or Toxic Release Inventory

\begin{tabular}{|c|c|c|}
\hline Substance & Formula & Reference \\
\hline & & $403,525, g 552,562,703$ \\
\hline Lindane(gamma-Benzenehexachloride) & $\mathrm{C}_{6} \mathrm{H}_{6} \mathrm{Cl}_{6}$ & $248,767,768$ \\
\hline Malachite Green & $\mathrm{C}_{23} \mathrm{H}_{25} \mathrm{CIN}_{2}$ & 848 \\
\hline Malathion & $\begin{array}{l}\left(\mathrm{CH}_{3} \mathrm{O}\right)_{2} \mathrm{P}(\mathrm{S}) \mathrm{SCH}\left(\mathrm{CO}_{2} \mathrm{C}_{2} \mathrm{H}_{5}\right)^{-} \\
\quad \mathrm{CH}_{2} \mathrm{CO}_{2} \mathrm{C}_{2} \mathrm{H}_{5}\end{array}$ & \\
\hline Maleic anhydride & $\mathrm{HC}: \mathrm{CHC}(\mathrm{O}) \mathrm{OC}(\mathrm{O})$ & \\
\hline $\begin{array}{l}\text { Maneb (Carbamodithioic acid, 1,2- } \\
\text { ethanediylbis-,manganese complex) }\end{array}$ & $\left(\mathrm{SSCNCH}{ }_{2} \mathrm{CH}_{2} \mathrm{NHCSS}\right) \mathrm{Mn}$ & \\
\hline Mechlorethamine & $\mathrm{CH}_{3} \mathrm{~N}\left(\mathrm{CH}_{2} \mathrm{CH}_{2} \mathrm{Cl}\right)_{2}$ & \\
\hline Melamine & $\mathrm{H}_{2} \mathrm{NCNC}\left(\mathrm{NH}_{2}\right) \mathrm{NC}\left(\mathrm{NH}_{2}\right) \mathrm{N}$ & \\
\hline Methanol & $\mathrm{CH}_{3} \mathrm{OH}$ & $\begin{array}{l}20, g 154, g 155,190,191 \\
192,458,486,496, g 638\end{array}$ \\
\hline Methoxychlor & $\mathrm{Cl}_{3} \mathrm{CCH}\left(\mathrm{C}_{6} \mathrm{H}_{4} \mathrm{OCH}_{3}\right)_{2}$ & \\
\hline Methyl acrylate & $\mathrm{CH}_{2}: \mathrm{CHCOOCH}_{3}$ & $g 154, g 155$ \\
\hline Methyl butyl ketone & $\mathrm{CH}_{3} \mathrm{COC}_{4} \mathrm{H}_{9}$ & \\
\hline Methyl ethyl ketone & $\mathrm{CH}_{3} \mathrm{COCH}_{2} \mathrm{CH}_{3}$ & $g 154, g 155$ \\
\hline Methyl iodide & $\mathrm{CH}_{3} \mathrm{l}$ & \\
\hline Methyl isobutyl ketone & $\left(\mathrm{CH}_{3}\right)_{2} \mathrm{CHCOCH}_{3}$ & \\
\hline Methyl isocyanate & $\mathrm{CH}_{3} \mathrm{NCO}$ & \\
\hline Methyl methacrylate & $\mathrm{CH}_{2}: \mathrm{C}\left(\mathrm{CH}_{3}\right) \mathrm{COOCH}_{3}$ & \\
\hline Methyl tert-butyl ether & $\left(\mathrm{CH}_{3}\right)_{3} \mathrm{COCH}$ & $g 154, g 155$ \\
\hline Methylene bromide & $\mathrm{CH}_{2} \mathrm{Br}_{2}$ & \\
\hline Methylene chloride & $\mathrm{CH}_{2} \mathrm{Cl}_{2}$ & $\begin{array}{l}\mathrm{g} 5,116,139, \mathrm{~g} 154, \mathrm{~g} 155 \\
227, \mathrm{~g} 488,571,574,750 \\
\mathrm{~g} 837\end{array}$ \\
\hline Methylenebis(phenylisocyanate) (MBI) & $\mathrm{CH}_{2}\left(\mathrm{C}_{6} \mathrm{H}_{4} \mathrm{NCO}\right)_{2}$ & \\
\hline Methylhydrazine & $\mathrm{CH}_{3} \mathrm{NHNH}_{2}$ & \\
\hline Michler's ketone & $\mathrm{CO}\left[\mathrm{C}_{6} \mathrm{H}_{4} \mathrm{~N}\left(\mathrm{CH}_{3}\right)_{2}\right]_{2}$ & \\
\hline Mirex & $\mathrm{C}_{10} \mathrm{Cl}_{12}$ & \\
\hline Mustard gas & $\mathrm{S}\left(\mathrm{CH}_{3} \mathrm{CH}_{2} \mathrm{Cl}\right)_{2}$ & \\
\hline m-Nitroaniline & $\mathrm{NO}_{2} \mathrm{C}_{6} \mathrm{H}_{4} \mathrm{NH}_{2}$ & \\
\hline $\mathrm{N}, \mathrm{N}$-Dimethylaniline & $\mathrm{C}_{6} \mathrm{H}_{5} \mathrm{~N}\left(\mathrm{CH}_{3}\right)_{2}$ & 275 \\
\hline Naphthalene & $\mathrm{C}_{10} \mathrm{H}_{8}$ & g590,599,741 \\
\hline Naphthylamine (alpha-, beta-) & $\mathrm{C}_{10} \mathrm{H}_{7} \mathrm{NH}_{2}$ & \\
\hline Nitrilotriacetic acid & $\mathrm{N}\left(\mathrm{CH}_{2} \mathrm{COOH}\right)_{3}$ & 769 \\
\hline Nitrobenzene & $\mathrm{C}_{6} \mathrm{H}_{5} \mathrm{NO}_{2}$ & $190,191,192,588,589$ \\
\hline $\begin{array}{l}\text { Nitrofen [Benzene, 2,4-dichloro-1- } \\
\text { (4-nitrophenoxy)-] }\end{array}$ & $\mathrm{C}_{12} \mathrm{H}_{7} \mathrm{Cl}_{2} \mathrm{NO}_{3}$ & \\
\hline $\begin{array}{l}\text { Nitrogen mustard (2-Chloro-N-(2- } \\
\text { chloroethyl)-N-methylethanamine) }\end{array}$ & $\left(\mathrm{ClCH}_{2} \mathrm{CH}_{2}\right)_{2} \mathrm{NCH}_{3}$ & \\
\hline Nitroglycerin & $\mathrm{CH}_{2} \mathrm{NO}_{3} \mathrm{CHNO}_{3} \mathrm{CH}_{2} \mathrm{NO}_{3}$ & g511,g512,g719 \\
\hline Nitrophenol & $\mathrm{NO}_{2} \mathrm{C}_{6} \mathrm{H}_{4} \mathrm{OH}$ & \\
\hline n-Butyl alcohol & $\mathrm{CH}_{3}\left(\mathrm{CH}_{2}\right)_{2} \mathrm{CH}_{2} \mathrm{OH}$ & \\
\hline n-Dioctyl phthalate & $\left(\mathrm{C}_{8} \mathrm{H}_{17} \mathrm{OOC}\right)_{2} \mathrm{C}_{6} \mathrm{H}_{4}$ & \\
\hline N-Nitrosodiethylamine & $\mathrm{C}_{4} \mathrm{H}_{10} \mathrm{~N}_{2} \mathrm{O}$ & \\
\hline N-Nitrosodimethylamine & $\left(\mathrm{CH}_{3}\right)_{2} \mathrm{~N}_{2} \mathrm{O}$ & \\
\hline
\end{tabular}


Table 1. Organic Compounds in EPA Lists of Priority Pollutants, Air Toxics, or Toxic Release Inventory

\begin{tabular}{|c|c|c|}
\hline Substance & Formula & Reference \\
\hline 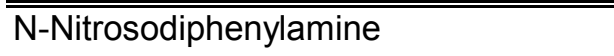 & $\left(\mathrm{C}_{6} \mathrm{H}_{5}\right)_{2} \mathrm{NNO}$ & \\
\hline N-Nitrosodi-n-butylamine & $\mathrm{ONN}\left(\mathrm{n}-\mathrm{C}_{4} \mathrm{H}_{9}\right)_{2}$ & \\
\hline N-Nitrosodi-n-propylamine & $\mathrm{ONN}\left(\mathrm{n}-\mathrm{C}_{3} \mathrm{H}_{7}\right)_{2}$ & \\
\hline N-Nitrosomethylvinylamine & $\mathrm{ONN}\left(\mathrm{CH}_{3}\right)\left(\mathrm{C}_{2} \mathrm{H}_{3}\right)$ & \\
\hline N-Nitrosomorpholine & $\mathrm{ONNC}_{4} \mathrm{H}_{8} \mathrm{O}$ & \\
\hline N-Nitrosonornicotine & & \\
\hline N-Nitrosopiperidine & $\mathrm{C}_{5} \mathrm{H}_{10} \mathrm{NHNO}$ & \\
\hline N-Nitroso-N-ethylurea & $\mathrm{C}(\mathrm{O})\left(\mathrm{NH}_{2}\right) \mathrm{N}(\mathrm{NO}) \mathrm{C}_{2} \mathrm{H}_{5}$ & \\
\hline $\mathrm{N}-$ Nitroso-N-methylurea & $\mathrm{C}(\mathrm{O})\left(\mathrm{NH}_{2}\right) \mathrm{N}(\mathrm{NO})\left(\mathrm{CH}_{3}\right)$ & \\
\hline n-Pentane & $\mathrm{CH}_{3}\left(\mathrm{CH}_{2}\right)_{3} \mathrm{CH}_{3}$ & \\
\hline Octachloronaphthalene & $\mathrm{C}_{10} \mathrm{Cl}_{8}$ & \\
\hline Octane & $\mathrm{CH}_{3}\left(\mathrm{CH}_{2}\right)_{6} \mathrm{CH}_{3}$ & $185,186, g 244$ \\
\hline Oxirane & $\mathrm{H}_{2} \mathrm{COCH}_{2}$ & \\
\hline o-Anisidine & $\mathrm{CH}_{3} \mathrm{OC}_{6} \mathrm{H}_{4} \mathrm{NH}_{2}$ & \\
\hline o-Anisidine hydrochloride & $\mathrm{CH}_{3} \mathrm{OC}_{6} \mathrm{H}_{4} \mathrm{NH}_{2} \cdot \mathrm{HCl}$ & \\
\hline o-Nitroaniline & $\mathrm{NO}_{2} \mathrm{C}_{6} \mathrm{H}_{4} \mathrm{NH}_{2}$ & \\
\hline o-Toluidine & $\mathrm{CH}_{3} \mathrm{C}_{6} \mathrm{H}_{4} \mathrm{NH}_{2}$ & \\
\hline o-Toluidine hydrochloride & $\mathrm{CH}_{3} \mathrm{C}_{6} \mathrm{H}_{4} \mathrm{NH}_{2} \cdot \mathrm{HCl}$ & \\
\hline Parathion (DNTP) & $\left(\mathrm{C}_{2} \mathrm{H}_{5} \mathrm{O}\right)_{2} \mathrm{P}(\mathrm{S}) \mathrm{OC}_{6} \mathrm{H}_{4} \mathrm{NO}_{2}$ & 137,138 \\
\hline PCBs (Aroclor $1260,1254,1248,1242$ ) & $\mathrm{C}_{12} \mathrm{Cl}_{x} \mathrm{H}_{10-\mathrm{x}}$ & $119,120,159,385$ \\
\hline Pentachlorobenzene & $\mathrm{C}_{6} \mathrm{Cl}_{5} \mathrm{H}$ & \\
\hline Pentachlorophenol & $\mathrm{C}_{6} \mathrm{Cl}_{5} \mathrm{OH}$ & $231,273,333,452,465,579$ \\
\hline Peracetic acid & $\mathrm{CH}_{3} \mathrm{COOOH}$ & \\
\hline Phenanthrene & $\mathrm{C}_{4} \mathrm{H}_{10}$ & \\
\hline Phenol & $\mathrm{C}_{6} \mathrm{H}_{5} \mathrm{OH}$ & $\begin{array}{l}6,7,14,85,98,100,107,117, \\
170,197,225,228,229,243, \\
278,297,408,462,468,501, \\
601,602,603,625,626,666, \\
678,687,688,714,731,752, \\
753,789,798,808,809\end{array}$ \\
\hline Phenol,2-methyl & $\mathrm{CH}_{3} \mathrm{C}_{6} \mathrm{H}_{4} \mathrm{OH}$ & \\
\hline Phosgene & $\mathrm{COCl}_{2}$ & \\
\hline Phthalic anhydride & $\mathrm{C}_{6} \mathrm{H}_{4}(\mathrm{CO})_{2} \mathrm{O}$ & 321 \\
\hline Picric acid & $\mathrm{C}_{6} \mathrm{H}_{2}\left(\mathrm{NO}_{2}\right)_{3} \mathrm{OH}$ & \\
\hline Polybrominatedbiphenyls & $\mathrm{C}_{12} \mathrm{BrxH}_{10-x}$ & \\
\hline Propane sultone & $\mathrm{C}_{3} \mathrm{H}_{6} \mathrm{SO}_{2}$ & \\
\hline Propionaldehyde & $\mathrm{C}_{2} \mathrm{H}_{5} \mathrm{CHO}$ & g726 \\
\hline Propiolactone, beta- & $\mathrm{OCH}_{2} \mathrm{CH}_{2} \mathrm{CO}$ & \\
\hline $\begin{array}{l}\text { Propoxur [Phenol, 2-(1-methylethoxy)- } \\
\text { methylcarbamate] }\end{array}$ & $\mathrm{C}_{11} \mathrm{H}_{15} \mathrm{NO}_{3}$ & \\
\hline Propylene oxide & $\mathrm{CH}_{2} \mathrm{OCHCH}_{3}$ & \\
\hline Propylene (Propene) & $\mathrm{CH}_{3} \mathrm{CH}: \mathrm{CH}_{2}$ & \\
\hline Propyleneimine & $\mathrm{CH}_{3} \mathrm{HCNHCH}_{2}$ & \\
\hline Pyrene & $\mathrm{C}_{16} \mathrm{H}_{10}$ & \\
\hline p-Anisidine & $\mathrm{CH}_{3} \mathrm{OC}_{6} \mathrm{H}_{4} \mathrm{NH}_{2}$ & \\
\hline
\end{tabular}


Table 1. Organic Compounds in EPA Lists of Priority Pollutants, Air Toxics, or Toxic Release Inventory

\begin{tabular}{|c|c|c|}
\hline - the & Formula & Reference \\
\hline p-Chloro-m-cresol & $\mathrm{C}_{6} \mathrm{H}_{3} \mathrm{CH}_{3} \mathrm{OHCl}$ & \\
\hline p-Cresidine & $\mathrm{CH}_{3} \mathrm{C}_{6} \mathrm{H}_{3}\left(\mathrm{NH}_{2}\right) \mathrm{OCH}_{3}$ & \\
\hline p-Nitrosodiphenylamine & $\left(\mathrm{C}_{6} \mathrm{H}_{5}\right)_{2} \mathrm{NNO}$ & \\
\hline p-Phenylenediamine & $\mathrm{C}_{6} \mathrm{H}_{4}\left(\mathrm{NH}_{2}\right)_{2}$ & \\
\hline Quinoline & $\mathrm{C}_{9} \mathrm{H}_{7} \mathrm{~N}$ & 122 \\
\hline Quinone & $\mathrm{C}_{6} \mathrm{H}_{4} \mathrm{O}_{2}$ & 278 \\
\hline Quintozene (Pentachloronitrobenzene) & $\mathrm{C}_{6} \mathrm{Cl}_{5} \mathrm{NO}_{2}$ & \\
\hline Safrole & $\mathrm{C}_{3} \mathrm{H}_{5} \mathrm{C}_{6} \mathrm{H}_{3} \mathrm{O}_{2} \mathrm{CH}_{2}$ & \\
\hline sec-Butyl alcohol & $\mathrm{CH}_{3} \mathrm{CH}_{2} \mathrm{CHOHCH}_{3}$ & \\
\hline Sevin (carbaryl) & $\mathrm{C}_{10} \mathrm{H}_{7} \mathrm{OOCNHCH}_{3}$ & \\
\hline Sodium Alizarinsulfonate & $\mathrm{SO}_{3} \mathrm{C}_{6} \mathrm{H}_{3}(\mathrm{CO})_{2} \mathrm{C}_{6} \mathrm{H}_{2}(\mathrm{OH})_{2} \mathrm{Na}$ & \\
\hline Styrene & $\mathrm{C}_{6} \mathrm{H}_{5} \mathrm{CH}: \mathrm{CH}_{2}$ & \\
\hline Styrene oxide & $\mathrm{C}_{6} \mathrm{H}_{5} \mathrm{CHOCH}_{2}$ & \\
\hline Terephthalic acid & $\mathrm{C}_{6} \mathrm{H}_{4}(\mathrm{COOH})_{2}$ & \\
\hline tert-Butyl alcohol & $\left(\mathrm{CH}_{3}\right)_{3} \mathrm{COH}$ & \\
\hline tert-Butylformate & $\left(\mathrm{CH}_{3}\right)_{3} \mathrm{COC}(\mathrm{O}) \mathrm{H}$ & \\
\hline Tetrachloroethylene & $\mathrm{Cl}_{2} \mathrm{C}: \mathrm{CCl}_{2}$ & $\begin{array}{l}\mathrm{g} 5, \mathrm{~g} 18,227, \mathrm{~g} 304, \mathrm{~g} 305 \\
330, \mathrm{~g} 330,349,535,571 \\
574, \mathrm{~g} 822\end{array}$ \\
\hline Tetrachlorvinphos & $\mathrm{C}_{10} \mathrm{HOCl}_{4} \mathrm{O}_{4} \mathrm{P}$ & \\
\hline Tetrahydrofuran & $\mathrm{CH}_{2} \mathrm{CH}_{2} \mathrm{CH}_{2} \mathrm{CH}_{2} \mathrm{O}$ & \\
\hline Thioacetamide & $\mathrm{CH}_{3} \mathrm{CSNH}_{2}$ & \\
\hline Thiourea & $\left(\mathrm{NH}_{2}\right)_{2} \mathrm{CS}$ & 182 \\
\hline Toluene & $\mathrm{C}_{6} \mathrm{H}_{5} \mathrm{CH}_{3}$ & $\begin{array}{l}\mathrm{g} 46,130,149,151, \mathrm{~g} 154, \\
\mathrm{~g} 155,176, \mathrm{~g} 213, \mathrm{~g} 214, \\
\mathrm{~g} 215,240, \mathrm{~g} 325, \mathrm{~g} 329, \\
\mathrm{~g} 394, \mathrm{~g} 410, \mathrm{~g} 439, \mathrm{~g} 484, \\
494, \mathrm{~g} 547, \mathrm{~g} 639, \mathrm{~g} 648, \\
\mathrm{~g} 717,756\end{array}$ \\
\hline Toluene diisocyanate & $\mathrm{CH}_{3} \mathrm{C}_{6} \mathrm{H}_{3}(\mathrm{NCO})_{2}$ & \\
\hline Toxaphene & $\mathrm{C}_{10} \mathrm{H}_{10} \mathrm{Cl}_{8}$ & \\
\hline Triaziquone & $\mathrm{C}_{12} \mathrm{H}_{13} \mathrm{~N}_{3} \mathrm{O}_{2}$ & \\
\hline Trichlorfon & $\left(\mathrm{CH}_{3} \mathrm{O}\right)_{2} \mathrm{P}(\mathrm{O}) \mathrm{CH}(\mathrm{OH}) \mathrm{CCl}_{3}$ & \\
\hline Trichloroethylene & $\mathrm{CHCl}: \mathrm{CCl}_{2}$ & $\begin{array}{l}\text { g5,8,9,10,g21,97,111,130, } \\
\text { 139,143,150,g154,g155, } \\
\text { g173,g174,g302,g303, } \\
\text { g305,g309,330,g330,349, } \\
\text { g359,g360,g377,g410, } \\
\text { g427,g428,g429,g439, } \\
447,448,449, \mathrm{~g} 491,510, \\
\text { g510, 535,571,574,g608, } \\
\text { g755, 757,g763,g778, } \\
\text { g780,g781, g822,g829 }\end{array}$ \\
\hline Triethylamine & $\mathrm{N}\left(\mathrm{C}_{2} \mathrm{H}_{5}\right)_{3}$ & 130 \\
\hline Trifluralin & $\mathrm{F}_{3} \mathrm{C}\left(\mathrm{NO}_{2}\right)_{2} \mathrm{C}_{6} \mathrm{H}_{2} \mathrm{~N}\left(\mathrm{C}_{3} \mathrm{H}_{7}\right)_{2}$ & \\
\hline
\end{tabular}


Table 1. Organic Compounds in EPA Lists of Priority Pollutants, Air Toxics, or Toxic Release Inventory

\begin{tabular}{l|l|l}
\hline Substance & Formula & Reference \\
\hline \hline Trinitrophenylmethylnitramine & $\left(\mathrm{NO}_{2}\right)_{3} \mathrm{C}_{6} \mathrm{H}_{2} \mathrm{~N}_{\left(\mathrm{NO}_{2}\right) \mathrm{CH}_{3}}$ & \\
Tris(2,3-dibromopropyl) phosphate & $\left(\mathrm{CH}_{2} \mathrm{BrCHBrCH}_{2} \mathrm{O}\right)_{3} \mathrm{PO}$ & \\
Urethane (ethyl carbamate) & $\mathrm{CO}\left(\mathrm{NH}_{2}\right) \mathrm{OC}_{2} \mathrm{H}_{5}$ & \\
Vinyl acetate & $\mathrm{CH}_{3} \mathrm{COOCH}: \mathrm{CH}_{2}$ & $\mathrm{~g} 154, \mathrm{~g} 155$ \\
Vinyl bromide & $\mathrm{CH}_{2} \mathrm{CHBr}$ & \\
Vinyl chloride & $\mathrm{CH}_{2}: \mathrm{CHCl}$ & \\
Vinylidene chloride & $\mathrm{CH}_{2}: \mathrm{CCl}_{2}$ & $151, \mathrm{~g} 154, \mathrm{~g} 155,240, \mathrm{~g} 325$, \\
Xylene (mixed isomers) & $\mathrm{C}_{6} \mathrm{H}_{4}\left(\mathrm{CH}_{3}\right)_{2}$ & $\mathrm{~g} 394, \mathrm{~g} 590,756$ \\
& & \\
Zineb & $\mathrm{Zn}\left(\mathrm{CS}_{2} \mathrm{NHCH}_{2}\right)_{2}$ & \\
\hline
\end{tabular}


Table 2. Other Organic Compounds Treated by a Photocatalytic Process

\begin{tabular}{|c|c|c|}
\hline Substance & Formula & Reference \\
\hline$\overline{1,1,1,2-T e t r a c h l o r o e t h a n e ~}$ & $\mathrm{Cl}_{3} \mathrm{CCH}_{2} \mathrm{Cl}$ & \\
\hline 1,1,1,2-Tetrafluoroethane & $\mathrm{F}_{3} \mathrm{CCH}_{2} \mathrm{~F}$ & 467 \\
\hline 1,3,5,7-Tetramethylcyclotetrasiloxane & & \\
\hline 1,1,1-Trifluoro-2,2,2-trichloroethane & $\mathrm{F}_{3} \mathrm{CCCl}_{3}$ & g325 \\
\hline 1,1,1-Trifluorobromochloroethane & $\mathrm{C}_{2} \mathrm{HF}_{3} \mathrm{ClBr}$ & \\
\hline 1,1,3-Trichloropropene & $\mathrm{Cl}_{2} \mathrm{CCHCH}_{2} \mathrm{Cl}$ & \\
\hline 1,1-Difluoro-1,2,2-trichloroethane & $\mathrm{ClF}_{2} \mathrm{CCHCl}_{2}$ & \\
\hline 1,1-Difluoro-1,2-dichloroethane & $\mathrm{FClCCClH}{ }_{2}$ & \\
\hline 1,1-Difluoroethylene & $\mathrm{CH}_{2} \mathrm{CF}_{2}$ & \\
\hline 1,1-Dimethyl-3-phenylurea & $\mathrm{C}_{6} \mathrm{H}_{5} \mathrm{NHC}(\mathrm{O}) \mathrm{N}\left(\mathrm{CH}_{3}\right)_{2}$ & \\
\hline 1,1-Diphenylethylene & $\left(\mathrm{C}_{6} \mathrm{H}_{5}\right) \mathrm{CCH}_{2}$ & \\
\hline 1,2-Dimethoxybenzene & $\left(\mathrm{CH}_{3} \mathrm{O}\right)_{2} \mathrm{C}_{6} \mathrm{H}_{4}$ & 614 \\
\hline 1,2-Bis(2-chloroethoxy)ethane & $\left(\mathrm{ClC}_{2} \mathrm{H}_{4}\right)_{2} \mathrm{C}_{2} \mathrm{H}_{4}$ & \\
\hline $1,2-, 1,3-$, or 1,4-Dinitrobenzene & $\left(\mathrm{NO}_{2}\right)_{2} \mathrm{C}_{6} \mathrm{H}_{4}$ & 93,94 \\
\hline 1,2,4-Benzenetricarboxylic acid & $\mathrm{C}_{6} \mathrm{H}_{3}\left(\mathrm{CO}_{2} \mathrm{H}\right)_{3}$ & 42 \\
\hline 1,2,4-Trinitrobenzene & $\mathrm{C}_{6} \mathrm{H}_{3}\left(\mathrm{NO}_{2}\right)_{2}$ & 162,166 \\
\hline 1,3,5-Trinitrobenzene & $\mathrm{C}_{6} \mathrm{H}_{3}\left(\mathrm{NO}_{2}\right)_{2}$ & 516 \\
\hline 1,2,4,5-Benzenetetracarboxylic acid & $\mathrm{C}_{6} \mathrm{H}_{2}\left(\mathrm{CO}_{2} \mathrm{H}\right)_{4}$ & 42 \\
\hline 1,2,4,5-Tetramethylbenzene & $\left(\mathrm{CH}_{3}\right)_{4} \mathrm{C}_{6} \mathrm{H}_{2}$ & \\
\hline 1,3-Dimethoxybenzene & $\left(\mathrm{CH}_{3} \mathrm{O}\right)_{2} \mathrm{C}_{6} \mathrm{H}_{4}$ & \\
\hline 1,3-Diphenylisobenzofuran & $\left(\mathrm{C}_{6} \mathrm{H}_{5}\right)_{2} \mathrm{C}_{6} \mathrm{H}_{2} \mathrm{OC}_{6} \mathrm{H}_{4}$ & \\
\hline 1,3,5-Benzenetricarboxylic acid & $\mathrm{C}_{6} \mathrm{H}_{3}\left(\mathrm{CO}_{2} \mathrm{H}\right)_{3}$ & 42 \\
\hline 1,3,5-Trimethylbenzene & $\left(\mathrm{CH}_{3}\right)_{3} \mathrm{C}_{6} \mathrm{H}_{3}$ & g325 \\
\hline 1,4-Dimethoxybenzene & $\left(\mathrm{CH}_{3} \mathrm{O}\right)_{2} \mathrm{C}_{6} \mathrm{H}_{4}$ & 614 \\
\hline 1,4-Dinitrobenzene & $\left(\mathrm{NO}_{2}\right) \mathrm{C}_{6} \mathrm{H}_{4}$ & 190,191 \\
\hline 1,4-Napthoquinone & $\mathrm{C}_{10} \mathrm{H}_{6} \mathrm{O}_{2}$ & \\
\hline 1,4-Pentanediole & $\mathrm{CH}_{3} \mathrm{CH}(\mathrm{OH})\left(\mathrm{CH}_{2}\right)_{3} \mathrm{OH}$ & \\
\hline 1-Benzylnicotinamide & $\left(\mathrm{C}_{6} \mathrm{H}_{5}\right) \mathrm{CH}_{2}\left(\mathrm{C}_{5} \mathrm{H}_{3} \mathrm{~N}\right) \mathrm{C}(\mathrm{O}) \mathrm{NH}_{2}$ & \\
\hline 1-Bromodecane & $\mathrm{BrC}_{10} \mathrm{H}_{21}$ & \\
\hline 1-Bromododecane & $\mathrm{BrC}_{12} \mathrm{H}_{25}$ & \\
\hline 1-Butanol & $\mathrm{CH}_{3}\left(\mathrm{CH}_{2}\right)_{3} \mathrm{OH}$ & $g 154, g 155$ \\
\hline 1-Decene & $\mathrm{CH}_{2} \mathrm{CHC}_{8} \mathrm{H}_{17}$ & g558 \\
\hline 1-Dodecanol & $\mathrm{CH}_{3}\left(\mathrm{CH}_{2}\right)_{11} \mathrm{OH}$ & \\
\hline 1-Hexene & $\mathrm{C}_{6} \mathrm{H}_{12}$ & g558 \\
\hline 1-(Methoxyphenyl)-2-propanol & $\left(\mathrm{CH}_{3} \mathrm{OC}_{6} \mathrm{H}_{4}\right)\left(\mathrm{CH}_{3}\right) \mathrm{CHOH}$ & \\
\hline 1-Phenylethanol & $\mathrm{CH}_{3} \mathrm{CH}\left(\mathrm{C}_{6} \mathrm{H}_{5}\right) \mathrm{OH}$ & \\
\hline 1-Propanol & $n-C_{3} \mathrm{H}_{7} \mathrm{OH}$ & \\
\hline 1-Nitronaphthalene & $\mathrm{C}_{10} \mathrm{H}_{7} \mathrm{NO}_{2}$ & \\
\hline 2,2-Dichloropropionic acid & $\mathrm{CH}_{3} \mathrm{CCl}_{2} \mathrm{CO}_{2} \mathrm{H}$ & \\
\hline 2,3-Dichloropyridine & $\mathrm{Cl}_{2} \mathrm{C}_{5} \mathrm{H}_{3} \mathrm{~N}$ & 390 \\
\hline 2,3- , 2,4- or 3,4-Difluorophenol & $\mathrm{F}_{2} \mathrm{C}_{6} \mathrm{H}_{3} \mathrm{OH}$ & \\
\hline $\begin{array}{l}\text { Tris-(2,4-dichlorophenoxy)ethyl- } \\
\text { phosphite }\end{array}$ & $\mathrm{C}_{2} \mathrm{H}_{5} \mathrm{P}\left[\mathrm{OC}_{6} \mathrm{H}_{3} \mathrm{Cl}_{2}\right]_{3}$ & \\
\hline 2,6-Dichlorophenol & $\mathrm{C}_{6} \mathrm{H}_{3} \mathrm{Cl}_{2} \mathrm{OH}$ & \\
\hline
\end{tabular}


Table 2. Other Organic Compounds Treated by a Photocatalytic Process

\begin{tabular}{|c|c|c|}
\hline Substance & Formula & Reference \\
\hline 2,7-Dichlorodibenzo-p-dioxin & $\mathrm{Cl}_{2} \mathrm{C}_{12} \mathrm{H}_{6} \mathrm{O}_{2}$ & \\
\hline 2-, 3-, or 4-Chlorobenzoic acid & $\mathrm{ClC}_{6} \mathrm{H}_{4} \mathrm{CO}_{2} \mathrm{H}$ & 723 \\
\hline 2-, 3-, or 4-Fluorophenol & $\mathrm{FC}_{6} \mathrm{H}_{4} \mathrm{OH}$ & \\
\hline 2-,3-, or 4-Nitrotoluene & $\mathrm{NO}_{2} \mathrm{C}_{6} \mathrm{H}_{4} \mathrm{CH}_{3}$ & 385 \\
\hline 2,3-Benzofuran & $\mathrm{C}_{8} \mathrm{H}_{6} \mathrm{O}$ & \\
\hline 2,3- and 2,5-Dichlorophenol & $\mathrm{Cl}_{2} \mathrm{C}_{6} \mathrm{H}_{3} \mathrm{OH}$ & \\
\hline 2,3-Dihydrobenzofuran & $\mathrm{C}_{8} \mathrm{H}_{8} \mathrm{O}$ & \\
\hline 2,3,5-Trichlorophenol & $\mathrm{Cl}_{3} \mathrm{C}_{6} \mathrm{H}_{2} \mathrm{OH}$ & 333,753 \\
\hline 2,4-Dihydroxybenzoic acid & $(\mathrm{HO})_{2} \mathrm{C}_{6} \mathrm{H}_{4}(\mathrm{OH}) \mathrm{CO}_{2} \mathrm{H}$ & 72 \\
\hline 2,4-Dimethoxybenzene & $\left(\mathrm{CH}_{3} \mathrm{O}\right)_{2} \mathrm{C}_{6} \mathrm{H}_{4}$ & \\
\hline 2,4-xylindine & $\mathrm{H}_{2} \mathrm{NC}_{6} \mathrm{H}_{3}\left(\mathrm{CH}_{3}\right)_{2}$ & 600 \\
\hline 2,5-Dinitrophenol & $\left(\mathrm{NO}_{2}\right)_{2} \mathrm{C}_{6} \mathrm{H}_{3} \mathrm{OH}$ & \\
\hline 2,6-Dichloroindophenol & $\mathrm{C}_{8} \mathrm{H}_{2} \mathrm{~N}(\mathrm{OH}) \mathrm{Cl}_{2}$ & \\
\hline 2,5-Furandimethanol & $\mathrm{C}_{4} \mathrm{H}_{2} \mathrm{O}\left(\mathrm{CH}_{2} \mathrm{OH}\right)_{2}$ & \\
\hline 2,4,6-Trichlorophenyl oxalate & $\left(\mathrm{Cl}_{3} \mathrm{C}_{6} \mathrm{H}_{2}\right) \mathrm{C}_{2} \mathrm{O}_{4}$ & 807 \\
\hline 2,4,6-Trinitrobenzoic acid & $\left(\mathrm{NO}_{2}\right)_{3} \mathrm{C}_{6} \mathrm{H}_{2} \mathrm{CO}_{2} \mathrm{H}$ & \\
\hline 2-Amino-5-diethylaminotoluene & $\left(\mathrm{NH}_{2}\right)\left[\left(\mathrm{C}_{2} \mathrm{H}_{5}\right)_{2} \mathrm{~N}\right] \mathrm{C}_{6} \mathrm{H}_{3} \mathrm{CH}_{3}$ & 432 \\
\hline 2-Chloroaniline & $\mathrm{ClC}_{6} \mathrm{H}_{4} \mathrm{NH}_{2}$ & 275 \\
\hline 2-Chlorobenzaldehyde & $\mathrm{ClC}_{6} \mathrm{H}_{4} \mathrm{C}(\mathrm{O}) \mathrm{H}$ & 67 \\
\hline 2-Chlorobiphenyl & $\mathrm{ClC}_{6} \mathrm{H}_{4} \mathrm{C}_{6} \mathrm{H}_{5}$ & 281 \\
\hline 2-Chlorodibenzo-p-dioxin & $\mathrm{ClC}_{12} \mathrm{H}_{7} \mathrm{O}_{2}$ & \\
\hline 2-Chloroethylethylsulfide & $\left(\mathrm{ClC}_{2} \mathrm{H}_{4}\right) \mathrm{C}_{2} \mathrm{H}_{5} \mathrm{~S}$ & 636 \\
\hline 2-Chloroethylmethylsulfide & $\left(\mathrm{ClC}_{2} \mathrm{H}_{4}\right) \mathrm{CH}_{3} \mathrm{~S}$ & \\
\hline 2-Coumaranone & $\mathrm{C}_{8} \mathrm{H}_{6} \mathrm{O}_{2}$ & \\
\hline 2-Furoic Acid & $\left(\mathrm{CH}_{2}\right)_{3} \mathrm{CHOCO}_{2} \mathrm{H}$ & \\
\hline 2-Hexene & $\mathrm{C}_{6} \mathrm{H}_{12}$ & g557 \\
\hline 2 or 3 or 4 -Hydroxyacetophenone & $\mathrm{HOC}_{6} \mathrm{H}_{4} \mathrm{C}(\mathrm{O}) \mathrm{CH}_{3}$ & 812 \\
\hline 2-Hydroxypyridine & $\mathrm{HOC}_{5} \mathrm{H}_{4} \mathrm{~N}$ & \\
\hline 2-Hydroxytetrahydropyran & $\mathrm{HOC}_{5} \mathrm{H}_{9} \mathrm{O}$ & \\
\hline 2-Methylbenzamidazole & $\mathrm{C}_{6} \mathrm{H}_{4} \mathrm{~N}_{2} \mathrm{HCCH}_{3}$ & 777 \\
\hline 2-Methylisoborneol & $\mathrm{C}_{11} \mathrm{H}_{20} \mathrm{OH}$ & 364 \\
\hline 2-Methylpropionic acid & $\left(\mathrm{CH}_{3}\right)_{2} \mathrm{CH}_{2} \mathrm{CO}_{2} \mathrm{H}$ & 717 \\
\hline 2-Methyl-1,4-hydroquinone & $\mathrm{CH}_{3} \mathrm{C}_{6} \mathrm{H}_{3}(\mathrm{OH})_{2}$ & 195 \\
\hline 2-Methyl-2-nitropropane & $\left(\mathrm{CH}_{3}\right)_{2} \mathrm{CHNO}_{2}$ & $190,191,192$ \\
\hline 2-Naphthol & $\mathrm{C}_{10} \mathrm{H}_{7} \mathrm{OH}$ & \\
\hline 2-Nitroaniline & $\mathrm{O}_{2} \mathrm{NC}_{6} \mathrm{H}_{4} \mathrm{NH}_{2}$ & \\
\hline 2-Tolualdehyde & $\mathrm{CH}_{3} \mathrm{C}_{6} \mathrm{H}_{4} \mathrm{CHO}$ & \\
\hline 2,2'-Dihydroxybiphenyl & $\mathrm{C}_{12} \mathrm{H}_{8}(\mathrm{OH})_{2}$ & \\
\hline 3,3,3-Trifluoropropene & $\mathrm{CH}_{2} \mathrm{CHCF}_{3}$ & \\
\hline 3,3'-Dichlorobiphenyl & $\left(\mathrm{ClC}_{6} \mathrm{H}_{4}\right)_{2}$ & \\
\hline 3,4,5-Trichlorophenol & $\mathrm{Cl}_{3} \mathrm{C}_{6} \mathrm{H}_{2} \mathrm{OH}$ & \\
\hline 3,4-Dichloroaniline & $\mathrm{Cl}_{2} \mathrm{C}_{6} \mathrm{H}_{3} \mathrm{NH}_{2}$ & 705 \\
\hline 3,4-Dichlorophenol & $3,4-\mathrm{Cl}_{2} \mathrm{C}_{6} \mathrm{H}_{3} \mathrm{OH}$ & \\
\hline 3,5-Dichlorophenol & $3,5-\mathrm{Cl}_{2} \mathrm{C}_{6} \mathrm{H}_{3} \mathrm{OH}$ & 333 \\
\hline 3-Aminoanisole & $\mathrm{CH}_{3} \mathrm{OC}_{6} \mathrm{H}_{4} \mathrm{NH}_{3}$ & \\
\hline
\end{tabular}


Table 2. Other Organic Compounds Treated by a Photocatalytic Process

\begin{tabular}{|c|c|c|}
\hline Substance & Formula & Reference \\
\hline $\begin{array}{l}\text { 3-Chloroaniline } \\
\text { 3-Chloroanisole } \\
\text { 3-Chlorobenzaldehyde }\end{array}$ & $\begin{array}{l}\mathrm{CH}_{3} \mathrm{OC}_{6} \mathrm{H}_{4} \mathrm{Cl} \\
\mathrm{ClC}_{6} \mathrm{H}_{4} \mathrm{NH}_{2} \\
\mathrm{ClC}_{6} \mathrm{H}_{4} \mathrm{C}(\mathrm{O}) \mathrm{H}\end{array}$ & $\begin{array}{l}275 \\
67\end{array}$ \\
\hline 3-Chlorophenol & $\mathrm{m}-\mathrm{ClC}_{6} \mathrm{H}_{4} \mathrm{OH}$ & \\
\hline 3-Chlorosalicylic acid & $\mathrm{C}_{7} \mathrm{H}_{5} \mathrm{ClO}_{3}$ & \\
\hline 3-Chlorotoluene & $\mathrm{CH}_{3} \mathrm{C}_{6} \mathrm{H}_{4} \mathrm{Cl}$ & \\
\hline 3-Fluoroanisole & $\mathrm{CH}_{3} \mathrm{OC}_{6} \mathrm{H}_{4} \mathrm{~F}$ & \\
\hline 3-Fluorotoluene & $\mathrm{CH}_{3} \mathrm{C}_{6} \mathrm{H}_{4} \mathrm{~F}$ & \\
\hline 3-hydroxyanisole & $\mathrm{CH}_{3} \mathrm{OC}_{6} \mathrm{H}_{4} \mathrm{OH}$ & \\
\hline 3-Methyl-2-oxobutanoic acid & $\left(\mathrm{CH}_{3}\right) \mathrm{CHC}(\mathrm{O}) \mathrm{CO}_{2} \mathrm{H}$ & \\
\hline 3-Nitroanisole & $\mathrm{CH}_{3} \mathrm{OC}_{6} \mathrm{H}_{4} \mathrm{NO}_{2}$ & \\
\hline 3-Nitrophenol & $\mathrm{O}_{2} \mathrm{NC}_{6} \mathrm{H}_{4} \mathrm{OH}$ & 476 \\
\hline 3-Nitrotoluene & $\mathrm{CH}_{3} \mathrm{C}_{6} \mathrm{H}_{4} \mathrm{NO}_{2}$ & \\
\hline 3-Octanol & $\mathrm{CH}_{3} \mathrm{CH}_{2} \mathrm{CH}(\mathrm{OH})\left(\mathrm{CH}_{2}\right)_{4} \mathrm{CH}_{3}$ & 715 \\
\hline 3-Octanone & $\mathrm{CH}_{3} \mathrm{CH}_{2} \mathrm{C}(\mathrm{O})\left(\mathrm{CH}_{2}\right)_{4} \mathrm{CH}_{3}$ & 715 \\
\hline 4-Acetobenzaldehyde & $\mathrm{CH}_{3} \mathrm{C}(\mathrm{O}) \mathrm{C}_{6} \mathrm{H}_{4} \mathrm{CHO}$ & \\
\hline 4-Aminoanisole & $\mathrm{CH}_{3} \mathrm{OC}_{6} \mathrm{H}_{4} \mathrm{NH}_{2}$ & \\
\hline 4-Bromophenol & $\mathrm{BrC}_{6} \mathrm{H}_{4} \mathrm{OH}$ & \\
\hline 4-t-Butyltoluene & $\mathrm{p}-\left(\mathrm{t}-\mathrm{C}_{4} \mathrm{H}_{9}\right) \mathrm{C}_{6} \mathrm{H}_{4} \mathrm{CH}_{3}$ & \\
\hline 4-Chloroanisole & $\mathrm{CH}_{3} \mathrm{OC}_{6} \mathrm{H}_{4} \mathrm{Cl}$ & \\
\hline 4-Chlorobenzaldehyde & $\mathrm{ClC}_{6} \mathrm{H}_{4} \mathrm{C}(\mathrm{O}) \mathrm{H}$ & 67,615 \\
\hline 4-Chlorocatachol & $\mathrm{ClC}_{6} \mathrm{H}_{3}(\mathrm{OH})_{2}$ & $351,352,353,354,695$ \\
\hline 4-Chloro-3-nitro-benzotrifluoride & $\mathrm{C}_{6} \mathrm{HCl}\left(\mathrm{NO}_{2}\right) \mathrm{F}_{3}$ & \\
\hline 4-Chlorophenol & $\mathrm{ClC}_{6} \mathrm{H}_{4} \mathrm{OH}$ & $\begin{array}{l}43,201,202,204,247,278 \\
362,408,422,423,465,501 \\
577,578,579,625,687,694 \\
695,696,742,743,753,761\end{array}$ \\
\hline 4-Chlorophenoxyacetic acid & $\mathrm{ClC}_{6} \mathrm{H}_{4} \mathrm{CH}_{2} \mathrm{CO}_{2} \mathrm{H}$ & 614 \\
\hline 4-Chlorophenylisocyanate & $\mathrm{ClC}_{6} \mathrm{H}_{4} \mathrm{NCO}$ & \\
\hline 4-Chlorotoluene & $\mathrm{CH}_{3} \mathrm{C}_{6} \mathrm{H}_{4} \mathrm{Cl}$ & \\
\hline 4-Fluoroanisole & $\mathrm{CH}_{3} \mathrm{OC}_{6} \mathrm{H}_{4} \mathrm{~F}$ & \\
\hline 4-Fluorophenol & $\mathrm{FC}_{6} \mathrm{H}_{4} \mathrm{OH}$ & \\
\hline 4-Fluorotoluene & $\mathrm{CH}_{3} \mathrm{C}_{6} \mathrm{H}_{4} \mathrm{~F}$ & \\
\hline 4-Hydroxyanisole & $\mathrm{CH}_{3} \mathrm{OC}_{6} \mathrm{H}_{4} \mathrm{OH}$ & \\
\hline 4-Hydroxyacetophenone & $\mathrm{HOC}_{6} \mathrm{H}_{4} \mathrm{C}(\mathrm{O}) \mathrm{CH}_{3}$ & \\
\hline 4-Hydroxybenzyl Alcohol & $\mathrm{p}-\mathrm{HO}\left(\mathrm{C}_{6} \mathrm{H}_{4}\right) \mathrm{CH}_{2} \mathrm{OH}$ & \\
\hline 4-Hydroxybiphenyl & $\mathrm{C}_{12} \mathrm{H}_{9} \mathrm{OH}$ & \\
\hline 4-lodophenol & $\mathrm{IC}_{6} \mathrm{H}_{4} \mathrm{OH}$ & \\
\hline 4-Methoxybenzylalcohol & $\mathrm{CH}_{3} \mathrm{OC}_{6} \mathrm{H}_{4} \mathrm{CH}_{2} \mathrm{OH}$ & 49 \\
\hline 4-Methoxybenzyl(methyl) ether & $\mathrm{CH}_{3} \mathrm{OC}_{6} \mathrm{H}_{4} \mathrm{CH}_{2} \mathrm{OCH}_{3}$ & 49 \\
\hline $\begin{array}{l}\text { 4-Methoxybenzyl(3-phenylpropyl)- } \\
\text { ether }\end{array}$ & $\mathrm{CH}_{3} \mathrm{OC}_{6} \mathrm{H}_{4} \mathrm{CH}_{2} \mathrm{O}\left(\mathrm{CH}_{2}\right)_{3} \mathrm{C}_{6} \mathrm{H}_{5}$ & \\
\hline 4-Methoxybenzyl(t-buytyl) ether & $\mathrm{CH}_{3} \mathrm{OC}_{6} \mathrm{H}_{4} \mathrm{CH}_{2} \mathrm{OC}\left(\mathrm{CH}_{3}\right)_{3}$ & 49 \\
\hline 4-Methoxybenzyl(phenyl)sulfide & $\mathrm{CH}_{3} \mathrm{OC}_{6} \mathrm{H}_{4} \mathrm{CH}_{2} \mathrm{SC}_{6} \mathrm{H}_{5}$ & 50 \\
\hline 4-Methoxyphenol & $\mathrm{CH}_{3} \mathrm{C}_{6} \mathrm{H}_{4} \mathrm{OH}$ & 147 \\
\hline 4-Nitroaniline & $\mathrm{NO}_{2} \mathrm{C}_{6} \mathrm{H}_{4} \mathrm{NH}_{2}$ & \\
\hline
\end{tabular}


Table 2. Other Organic Compounds Treated by a Photocatalytic Process

\begin{tabular}{|c|c|c|}
\hline Substance & Formula & Reference \\
\hline 4-Nitroanisole & $\mathrm{CH}_{3} \mathrm{OC}_{6} \mathrm{H}_{4} \mathrm{NO}_{2}$ & $190,191,192$ \\
\hline 4-Nitrobenzaldehyde & $\mathrm{NO}_{2} \mathrm{C}_{6} \mathrm{H}_{4} \mathrm{CHO}$ & $190,191,192$ \\
\hline 4-Nitrobenzamide & $\mathrm{NO}_{2} \mathrm{C}_{6} \mathrm{H}_{4} \mathrm{CONH}_{2}$ & $190,191,192$ \\
\hline 4-Nitrobenzenesulfanamide & $\mathrm{NO}_{2} \mathrm{C}_{6} \mathrm{H}_{4} \mathrm{SO}_{2} \mathrm{NH}_{2}$ & $190,191,192$ \\
\hline 4-Nitrobenzoic acid & $\mathrm{O}_{2} \mathrm{NC}_{6} \mathrm{H}_{4} \mathrm{CO}_{2} \mathrm{H}$ & 614 \\
\hline 4-Nitrocatechol & $\left(\mathrm{NO}_{2}\right) \mathrm{C}_{6} \mathrm{H}_{3}(\mathrm{OH})_{2}$ & $190,191,192$ \\
\hline 4-Nitromethylbenzenesulfonate & $\mathrm{NO}_{2} \mathrm{C}_{6} \mathrm{H}_{4} \mathrm{SO}_{3} \mathrm{CH}_{3}$ & $190,191,192$ \\
\hline 4-Nitromethylbenzoate & $\mathrm{NO}_{2} \mathrm{C}_{6} \mathrm{H}_{4} \mathrm{CO}_{2} \mathrm{CH}_{3}$ & $190,191,192$ \\
\hline 4-Nitrophenylethylphosphinate & $\left(\mathrm{NO}_{2}\right) \mathrm{C}_{6} \mathrm{H}_{4}\left(\mathrm{C}_{2} \mathrm{H}_{5}\right) \mathrm{PO}_{2}$ & \\
\hline 4-Nitrophenylisopropylphosphinate & $\left(\mathrm{NO}_{2} \mathrm{C}_{6} \mathrm{H}_{5}\right)\left(\mathrm{C}_{3} \mathrm{H}_{7}\right) \mathrm{HPO}_{3}$ & \\
\hline 4-Nitrophenyldiethylphosphate & $\left(\mathrm{NO}_{2} \mathrm{C}_{6} \mathrm{H}_{5}\right)\left(\mathrm{C}_{2} \mathrm{H}_{5}\right)_{2} \mathrm{PO}_{4}$ & \\
\hline 4-Nitrosophenol & $\mathrm{ONC}_{6} \mathrm{H}_{4} \mathrm{OH}$ & 588,589 \\
\hline 4-Nitrotoluene & $\mathrm{CH}_{3} \mathrm{C}_{6} \mathrm{H}_{4} \mathrm{NO}_{2}$ & $190,191,192$ \\
\hline 4-Phenylbutylamine & $\mathrm{C}_{6} \mathrm{H}_{5}\left(\mathrm{CH}_{2}\right)_{4} \mathrm{NH}_{2}$ & \\
\hline 4-Picoline & $\mathrm{CH}_{3} \mathrm{C}_{5} \mathrm{H}_{4} \mathrm{~N}$ & \\
\hline 4-Thiophenyl-1-butanol & $\mathrm{C}_{6} \mathrm{H}_{5} \mathrm{~S}\left(\mathrm{CH}_{2}\right)_{4} \mathrm{OH}$ & \\
\hline 4-Trifluoromethylphenol & $\mathrm{CF}_{3} \mathrm{C}_{6} \mathrm{H}_{4} \mathrm{OH}$ & \\
\hline 4,4'-Dihydroxybiphenyl & $\mathrm{C}_{12} \mathrm{H}_{8}(\mathrm{OH})_{2}$ & \\
\hline 5-Bromouracil & $\mathrm{BrC}_{4} \mathrm{H}(\mathrm{NH})_{2}(\mathrm{O})_{2}$ & 11 \\
\hline 5-Chlorouracil & $\mathrm{ClC}_{4} \mathrm{H}(\mathrm{NH})_{2}(\mathrm{O})_{2}$ & 11,766 \\
\hline 5-Fluorouracil & $\mathrm{FC}_{4} \mathrm{H}(\mathrm{NH})_{2}(\mathrm{O})_{2}$ & 11,766 \\
\hline 5-Hydroxypentanoic acid & $\mathrm{HO}\left(\mathrm{CH}_{2}\right)_{4} \mathrm{CO}_{2} \mathrm{H}$ & \\
\hline 6-Methoxytetralin & $\mathrm{CH}_{3} \mathrm{OC}_{8} \mathrm{H}_{5} \mathrm{O}$ & \\
\hline 5-Methylresorcinol & $\mathrm{CH}_{3} \mathrm{C}_{6} \mathrm{H}_{5} \mathrm{O}_{2}$ & 601,602 \\
\hline 9,10-Anthraquinone & & 741 \\
\hline 12-Nitrododecanoic acid & $\mathrm{NO}_{2} \mathrm{C}_{11} \mathrm{H}_{22} \mathrm{CO}_{2} \mathrm{H}$ & \\
\hline 12-phenyldodecanesulfonate, sodium salt & $\mathrm{C}_{6} \mathrm{H}_{5}\left(\mathrm{CH}_{2}\right)_{12} \mathrm{SO}_{3} \mathrm{H}$ & \\
\hline Acenapthane & $\mathrm{C}_{10} \mathrm{H}_{16}\left(\mathrm{CH}_{2}\right)_{2}$ & \\
\hline Acetic Acid or acetate ion & $\mathrm{CH}_{3} \mathrm{CO}_{2} \mathrm{H}$ & $\begin{array}{l}203,369,374,496,543,632 \\
658,681,731\end{array}$ \\
\hline Acetophenone & $\mathrm{CH}_{3} \mathrm{COC}_{6} \mathrm{H}_{5}$ & $811,812,813$ \\
\hline Acetylene & $\mathrm{C}_{2} \mathrm{H}_{2}$ & \\
\hline Acid Blue 40 & & 507 \\
\hline Acid orange 7 & $\mathrm{Na}, \mathrm{O}_{3} \mathrm{SC}_{6} \mathrm{H}_{4} \mathrm{~N}_{2} \mathrm{C}_{10} \mathrm{H}_{6} \mathrm{OH}$ & \\
\hline Adipic acid & $\mathrm{C}_{5} \mathrm{H}_{11} \mathrm{CO}_{2} \mathrm{H}$ & 320 \\
\hline Aldicarb & $\mathrm{CH}_{3} \mathrm{SC}\left(\mathrm{CH}_{3}\right)_{2} \mathrm{CHN}(\mathrm{O}) \mathrm{C}(\mathrm{O}) \mathrm{NHCH}_{3}$ & \\
\hline L-Alanine & $\mathrm{CH}_{3} \mathrm{CH}\left(\mathrm{NH}_{2}\right) \mathrm{CO}_{2} \mathrm{H}$ & $132,133,267,288$ \\
\hline Alizarin Red S Biological Stain & & 617 \\
\hline p-Alkylphenol (various) & $\mathrm{R}\left(\mathrm{C}_{6} \mathrm{H}_{4}\right) \mathrm{OH}$ & \\
\hline Allyl alcohol & $\mathrm{C}_{3} \mathrm{H}_{5} \mathrm{OH}$ & \\
\hline Alochlor & & 580 \\
\hline Ametryn & & 501 \\
\hline Aminophenol, 2, 3, or 4 & $\mathrm{NH}_{2} \mathrm{C}_{6} \mathrm{H}_{4} \mathrm{OH}$ & 250,476 \\
\hline $\begin{array}{l}\text { o-Anisidine } \\
\text { Anthraquinone-2-sulfonic acid } \\
\text { AOX or Haloform Precursors }\end{array}$ & $\begin{array}{l}\mathrm{CH}_{3} \mathrm{OC}_{6} \mathrm{H}_{4} \mathrm{NH}_{2} \\
\mathrm{HO}_{3} \mathrm{SC}_{14} \mathrm{H}_{7} \mathrm{O}_{2}\end{array}$ & 275 \\
\hline
\end{tabular}


Table 2. Other Organic Compounds Treated by a Photocatalytic Process

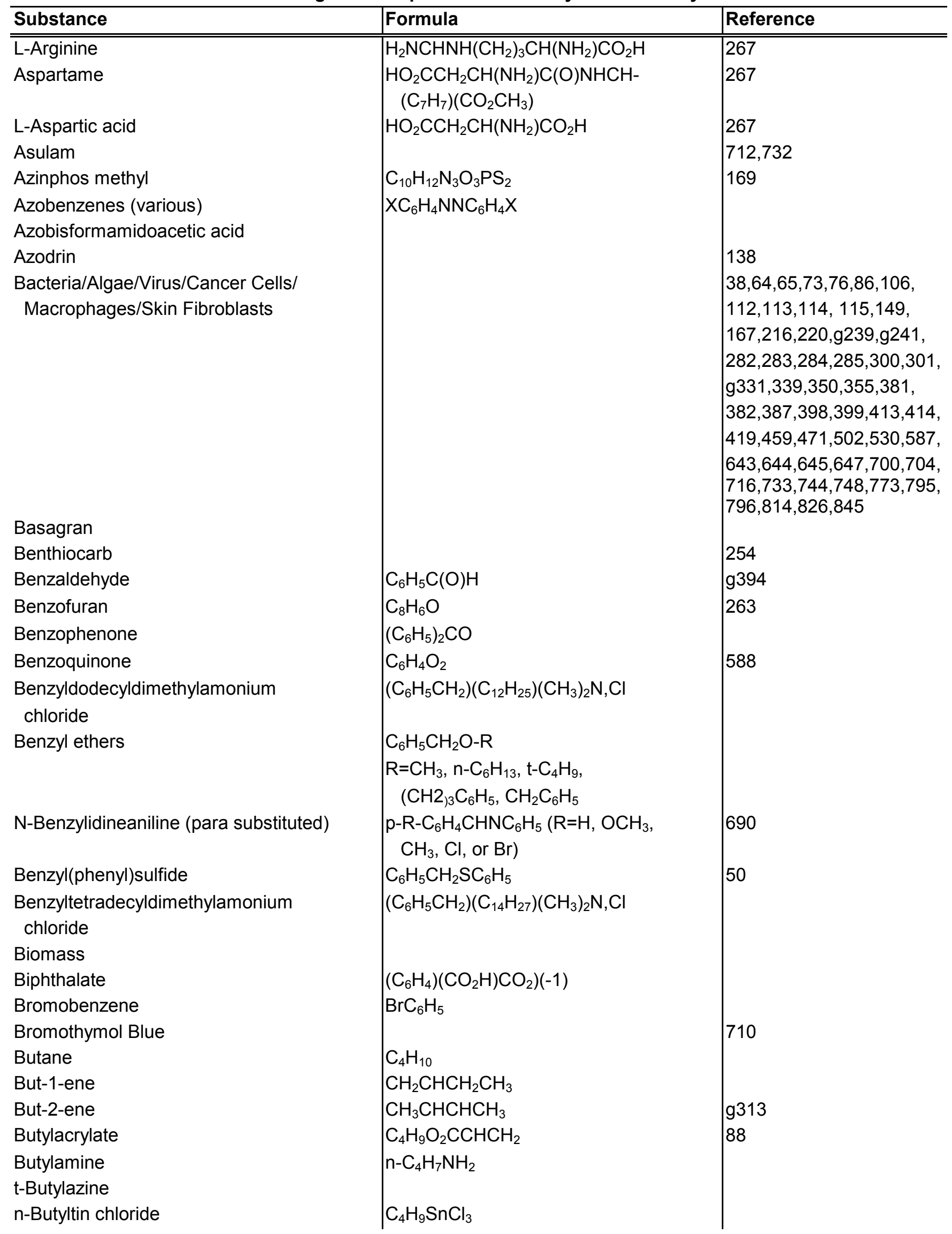


Table 2. Other Organic Compounds Treated by a Photocatalytic Process

\begin{tabular}{|c|c|c|}
\hline Substance & Formula & Reference \\
\hline But-1-yne & $\mathrm{CHCCH}_{2} \mathrm{CH}_{3}$ & \\
\hline Butyric acid & $\mathrm{C}_{3} \mathrm{H}_{7} \mathrm{CO}_{2} \mathrm{H}$ & \\
\hline Carbetamide & & 11,198 \\
\hline Carbofuran & & 739 \\
\hline Carbon dioxide (reduction) & $\mathrm{CO}_{2}$ & $\begin{array}{l}34,35,36,340,341,674,675, \\
827\end{array}$ \\
\hline Carbon monoxide & co & $\mathrm{g} 18, \mathrm{~g} 771, \mathrm{~g} 772$ \\
\hline Carbon tetrabromide & $\mathrm{CBr}_{4}$ & \\
\hline Catalase & & 382 \\
\hline Catechol & $\mathrm{C}_{6} \mathrm{H}_{4}(\mathrm{OH})_{2}$ & 666 \\
\hline C12-Betaine & $\left(\mathrm{C}_{12} \mathrm{H}_{25}\right)\left(\mathrm{CH}_{3}\right)_{2} \mathrm{NCO}_{2}$ & \\
\hline C12-Amidobetaine & & \\
\hline Cetyldimethylbenzylamonium chloride & $\begin{array}{l}\mathrm{CH}_{3}\left(\mathrm{CH}_{2}\right)_{15}\left(\mathrm{CH}_{3}\right)_{2-} \\
\left(\mathrm{C}_{6} \mathrm{H}_{5} \mathrm{CH}_{2}\right) \mathrm{N}, \mathrm{Cl}\end{array}$ & \\
\hline Cetylpyridinium chloride or bromide & $\mathrm{N}-\left[\mathrm{CH}_{3}\left(\mathrm{CH}_{2}\right)_{15}\right]\left(\mathrm{C}_{5} \mathrm{H}_{5} \mathrm{~N}\right), \mathrm{Cl}$ (or Br) & $544,685,720$ \\
\hline Cetyltrimethylammonium bromide & $\mathrm{CH}_{3}\left(\mathrm{CH}_{2}\right)_{15}\left(\mathrm{CH}_{3}\right)_{3} \mathrm{~N}, \mathrm{Cl}$ & \\
\hline Chloroacetaldehyde & $\mathrm{CH}_{2} \mathrm{ClC}(\mathrm{O}) \mathrm{H}$ & \\
\hline $\begin{array}{l}\text { Chlorobenzoic acids, o-, m-, or p- } \\
\text { Chlorofluorocarbons, various }\end{array}$ & $\mathrm{Cl}\left(\mathrm{C}_{6} \mathrm{H}_{4}\right) \mathrm{CO}_{2} \mathrm{H}$ & 325 \\
\hline Chloral hydrate & $\mathrm{Cl}_{3} \mathrm{CO}(\mathrm{OH})_{2}$ & \\
\hline Chloranil, o- and p- & $\mathrm{C}_{6} \mathrm{Cl}_{4} \mathrm{O}_{2}$ & \\
\hline Chloroethylammonium chloride & $\mathrm{ClH}_{3} \mathrm{~N}, \mathrm{Cl}$ & \\
\hline Chlorpyrifos & & \\
\hline Ciba Orange RI & & \\
\hline Cinnamyl alcohol & $\mathrm{C}_{6} \mathrm{H}_{4} \mathrm{C}_{2} \mathrm{H}_{2} \mathrm{OH}$ & \\
\hline Citric acid & $\mathrm{HO}_{2} \mathrm{CCH}_{2} \mathrm{C}(\mathrm{OH})\left(\mathrm{CO}_{2} \mathrm{H}\right) \mathrm{CH}_{2} \mathrm{CO}_{2} \mathrm{H}$ & \\
\hline Coal or Carbon & & \\
\hline Color and/or COD (in wastewater) & & \\
\hline Congo Red & $\mathrm{C}_{32} \mathrm{H}_{22} \mathrm{O}_{6} \mathrm{~N}_{6} \mathrm{~S}_{2} \mathrm{Na}_{2}$ & \\
\hline Cresol violet & $\mathrm{C}_{16} \mathrm{H}_{8} \mathrm{NO}\left(\mathrm{NH}_{2}\right), \mathrm{Cl}$ & \\
\hline Creosote phenolics & & \\
\hline p-Coumaric acid & $\mathrm{HOC}_{6} \mathrm{H}_{4} \mathrm{CHCHCO}_{2} \mathrm{H}$ & 51 \\
\hline Cyanamide & $\mathrm{NCNH}_{2}$ & 182 \\
\hline Cyanuric acid & $\mathrm{C}_{3} \mathrm{~N}_{3}(\mathrm{OH})_{3}$ & 475 \\
\hline Cyclododecanol & $\mathrm{C}_{12} \mathrm{H}_{23} \mathrm{OH}$ & \\
\hline Cyclohexanedicarboxylic acids & $\mathrm{C}_{6} \mathrm{H}_{10}\left(\mathrm{CO}_{2} \mathrm{H}\right)_{2}$ & \\
\hline Cyclohexanol & $\mathrm{C}_{6} \mathrm{H}_{11} \mathrm{OH}$ & \\
\hline Cyclohexene & $\mathrm{C}_{6} \mathrm{H}_{10}$ & 87 \\
\hline Cyclohexene oxide & $\mathrm{C}_{6} \mathrm{H}_{10} \mathrm{O}$ & \\
\hline Cyclooctatetraene & $\mathrm{C}_{8} \mathrm{H}_{8}$ & \\
\hline Cyclopentane & $\mathrm{C}_{5} \mathrm{H}_{10}$ & \\
\hline Cyclophosphamide & OPONHC ${ }_{3} \mathrm{H}_{6}\left[\mathrm{~N}\left(\mathrm{C}_{2} \mathrm{H}_{4} \mathrm{Cl}\right)_{2}\right]$ & \\
\hline D,L-Cysteine & $\mathrm{HSCH}_{2} \mathrm{CH}\left(\mathrm{NH}_{2}\right) \mathrm{CO}_{2} \mathrm{H}$ & 267,382 \\
\hline DDT & $\left(\mathrm{ClC}_{6} \mathrm{H}_{4}\right)_{2} \mathrm{CHCCl}_{3}$ & 142 \\
\hline DNA and RNA & & $171,177,269,300,773$ \\
\hline
\end{tabular}


Table 2. Other Organic Compounds Treated by a Photocatalytic Process

\begin{tabular}{|c|c|c|}
\hline Substance & Formula & Reference \\
\hline Decalin & $\mathrm{C}_{10} \mathrm{H}_{18}$ & \\
\hline Decamethyltetrasiloxane & $\left(\mathrm{CH}_{3}\right)_{10} \mathrm{Si}_{4} \mathrm{O}_{3}$ & g582 \\
\hline Decanoic acid & $\mathrm{C}_{9} \mathrm{H}_{19} \mathrm{CO}_{2} \mathrm{H}$ & \\
\hline Decanol & $\mathrm{HOC}_{10} \mathrm{H}_{21}$ & \\
\hline Desipramine & $\left(\mathrm{C}_{6} \mathrm{H}_{4}\right)_{2}\left(\mathrm{CH}_{2}\right)_{2} \mathrm{~N}\left(\mathrm{CH}_{2}\right)_{3} \mathrm{NHCH}_{3}$ & \\
\hline Diazinon & $\begin{array}{l}{\left[\left(\mathrm{CH}_{3}\right)_{2} \mathrm{CHC}_{4} \mathrm{~N}_{2} \mathrm{H}\left(\mathrm{CH}_{3}\right) \mathrm{O}\right]-} \\
\mathrm{PS}\left(\mathrm{OC}_{2} \mathrm{H}_{5}\right)_{2}\end{array}$ & 254 \\
\hline Dibenzothiophene & $\mathrm{C}_{12} \mathrm{H}_{8} \mathrm{~S}$ & 1 \\
\hline Dibenzo-p-dioxines, various & $\mathrm{X}_{\mathrm{n}} \mathrm{C}_{1}{ }_{2} \mathrm{H}_{(8-n)} \mathrm{O}_{2}(\mathrm{X}=\mathrm{Cl}$ or $\mathrm{Br})$ & 274 \\
\hline Dibenzylsulfone & {$\left[\mathrm{C}_{6} \mathrm{H}_{5} \mathrm{CH}_{2}\right)_{2} \mathrm{SO}_{2}$} & 152 \\
\hline Dibromomethane & $\mathrm{CH}_{2} \mathrm{Br}_{2}$ & \\
\hline Dichloroacetic acid & $\mathrm{Cl}_{2} \mathrm{CHCO}_{2} \mathrm{H}$ & $\begin{array}{l}52,53,59,60,89,90,91,227 \\
235,357,421,422,423,462, \\
465,579,668,684,764,823\end{array}$ \\
\hline Dichloroacetyl Chloride & $\mathrm{Cl}_{2} \mathrm{CHCOCl}$ & \\
\hline Diethyl ether & $\left(\mathrm{C}_{2} \mathrm{H}_{5}\right)_{2} \mathrm{O}$ & g770,g771 \\
\hline Diethylmethylphosphonate & $\left(\mathrm{C}_{2} \mathrm{H}_{5}\right)_{2} \mathrm{CH}_{3} \mathrm{PO}_{2}$ & 546 \\
\hline Dihexadecylphosphate & $\left(\mathrm{C}_{16} \mathrm{H}_{33}\right)_{2} \mathrm{PO}_{4} \mathrm{H}$ & 386 \\
\hline Dimethoate & $\left(\mathrm{CH}_{3} \mathrm{O}\right)_{2} \mathrm{PSSCH}_{2} \mathrm{CONHCH}_{3}$ & 169 \\
\hline Dimethylacetamide & $\mathrm{CH}_{3} \mathrm{C}(\mathrm{O}) \mathrm{N}\left(\mathrm{CH}_{3}\right)_{2}$ & \\
\hline Dimethylamine & $\left(\mathrm{CH}_{3}\right) 2 \mathrm{NH}$ & \\
\hline Dimethylmethylphosphonate & $\left(\mathrm{CH}_{3}\right)_{2} \mathrm{CH}_{3} \mathrm{PO}_{2}$ & 546 \\
\hline $\begin{array}{l}\text { Dimethyl-2,2,2-trichloro-1-hydroxyethyl- } \\
\text { phosphonate }\end{array}$ & $\left(\mathrm{CH}_{3}\right)_{2}\left[\mathrm{CCl}_{3} \mathrm{CH}_{2}(\mathrm{OH})\right] \mathrm{PO}_{2}$ & 731 \\
\hline Dimethylphenols (Xylenols) & $\left(\mathrm{CH}_{3}\right)_{2} \mathrm{C}_{6} \mathrm{H}_{3} \mathrm{OH}$ & \\
\hline Dimethylsulfide & $\left(\mathrm{CH}_{3}\right)_{2} \mathrm{~S}$ & g582 \\
\hline Dimethyl-2,2-dichlorovinyl phosphate & $\left(\mathrm{CH}_{3}\right)_{2}\left(\mathrm{Cl}_{2} \mathrm{CCH}\right) \mathrm{PO}_{4}$ & \\
\hline Diphenylacetylene & $\left(\mathrm{C}_{6} \mathrm{H}_{5}\right)_{2} \mathrm{C}_{2}$ & \\
\hline Diphenylamine & $\left(\mathrm{C}_{6} \mathrm{H}_{5}\right)_{2} \mathrm{NH}$ & $93,94,275$ \\
\hline Diphenylmethane & $\left(\mathrm{C}_{6} \mathrm{H}_{5}\right)_{2} \mathrm{CH}_{2}$ & \\
\hline Diphenylsulfide & $\left(\mathrm{C}_{6} \mathrm{H}_{5}\right)_{2} \mathrm{~S}$ & \\
\hline Diphenyltin chloride & $\left(\mathrm{C}_{6} \mathrm{H}_{5}\right)_{2} \mathrm{SnCl}_{2}$ & 524 \\
\hline Direct blue 1 & $\begin{array}{l}{\left[\left(\mathrm{Na}, \mathrm{O}_{3} \mathrm{~S}\right) \mathrm{C}_{16} \mathrm{H}_{6}\left(\mathrm{NH}_{2}\right)(\mathrm{OH})-\right.} \\
\left.\quad\left(\mathrm{OCH}_{3}\right) \mathrm{N}_{2}\right]_{2}\end{array}$ & \\
\hline \multicolumn{3}{|l|}{ Diquat } \\
\hline Disinfection by-products & & 629 \\
\hline Disperse blue 79 & & 523 \\
\hline \multicolumn{3}{|l|}{ Disperse red 74} \\
\hline Diuron & $\mathrm{C}_{6} \mathrm{H}_{3} \mathrm{Cl}_{2} \mathrm{NHC}(\mathrm{O}) \mathrm{N}\left(\mathrm{CH}_{3}\right)_{2}$ & 378,508 \\
\hline Dodecane & $\mathrm{C}_{12} \mathrm{H}_{26}$ & 134,494 \\
\hline Dodecyl sulfate, sodium salt & $\left(\mathrm{C}_{12} \mathrm{H}_{25}\right)_{2} \mathrm{SO}_{4}, \mathrm{Na}$ & $396,606,765$ \\
\hline Dodecylbenzenesulfonate & $\left(\mathrm{C}_{12} \mathrm{H}_{25}\right) \mathrm{C}_{6} \mathrm{H}_{4} \mathrm{SO}_{3}(-1)$ & 169 \\
\hline Dodecyldecaoxyethylenephosphates & & \\
\hline Dodecylpyridinium chloride & $\left(\mathrm{C}_{12} \mathrm{H}_{25}\right) \mathrm{C}_{5} \mathrm{H}_{5} \mathrm{NH}, \mathrm{Cl}$ & \\
\hline \multicolumn{3}{|l|}{ Doxycycline } \\
\hline Drimarene Yellow 3 GLI & & 710 \\
\hline
\end{tabular}


Table 2. Other Organic Compounds Treated by a Photocatalytic Process

\begin{tabular}{|c|c|c|}
\hline Substance & Formula & Reference \\
\hline $\begin{array}{l}\text { Eosin } \\
\text { Ethambutol } \\
\text { Ethane }\end{array}$ & $\mathrm{C}_{2} \mathrm{H}_{6}$ & $\begin{array}{l}207,208,209,210,233,365, \\
401,415,542,605,735,785 \\
804,805,825,842,843,853, \\
615,844\end{array}$ \\
\hline Ethanol & $\mathrm{C}_{2} \mathrm{H}_{5} \mathrm{OH}$ & $\begin{array}{l}89,318, \mathrm{~g} 347, \mathrm{~g} 348, \mathrm{~g} 504 \\
\mathrm{~g} 505, \mathrm{~g} 506, \mathrm{~g} 511, \mathrm{~g} 512 \\
\mathrm{~g} 521, \mathrm{~g} 734, \mathrm{~g} 770, \mathrm{~g} 771\end{array}$ \\
\hline Ethylacetate & $\mathrm{CH}_{3} \mathrm{CO}_{2} \mathrm{C}_{2} \mathrm{H}_{5}$ & g770,g771 \\
\hline $\begin{array}{l}\text { Ethylenediaminetetraacetic acid and } \\
\text { metal complexes } \\
\text { 2-, 3-, or 4-Ethylphenol }\end{array}$ & $\begin{array}{l}\left(\mathrm{HO}_{2} \mathrm{CCH}_{2}\right)_{4} \mathrm{~N}_{2} \mathrm{C}_{2} \mathrm{H}_{4} \\
\left(\mathrm{C}_{2} \mathrm{H}_{5}\right) \mathrm{C}_{6} \mathrm{H}_{4} \mathrm{OH}\end{array}$ & $\begin{array}{l}124,278,338,424,442,443 \\
709\end{array}$ \\
\hline Fast Orange GC Base & & 710 \\
\hline Fenitrothion & $\mathrm{C}_{9} \mathrm{H}_{12} \mathrm{NO}_{5} \mathrm{PS}$ & 254 \\
\hline Fenobucarb & & 254 \\
\hline $\begin{array}{l}\text { Fluorescein } \\
\text { Folicur }\end{array}$ & $\mathrm{C}_{2} \mathrm{OH}_{12} \mathrm{O}_{5}$ & \\
\hline Formamide & $\mathrm{HC}(\mathrm{O}) \mathrm{NH}_{2}$ & \\
\hline Formic acid or formate ion & $\mathrm{HCO}_{2} \mathrm{H}$ & $\begin{array}{l}160,203,205,251,310,358 \\
424,501\end{array}$ \\
\hline Fullerenes & $\mathrm{C}_{60}, \mathrm{C}_{70}$, and $\mathrm{C}_{84}$ & \\
\hline $\begin{array}{l}\text { Fulvic acid } \\
\text { beta-D-Galactosidase } \\
\text { Geosmin }\end{array}$ & & $\begin{array}{l}301 \\
364\end{array}$ \\
\hline Glucose & $\mathrm{C}_{6} \mathrm{H}_{11} \mathrm{O}_{6}$ & \\
\hline L-Glutamic acid & $\mathrm{HO}_{2} \mathrm{C}\left(\mathrm{CH}_{2}\right)_{2} \mathrm{CH}\left(\mathrm{NH}_{2}\right) \mathrm{CO}_{2} \mathrm{H}$ & 267 \\
\hline $\begin{array}{l}\text { L-Glutamine } \\
\text { Glycerol }\end{array}$ & $\begin{array}{l}\mathrm{H}_{2} \mathrm{NC}\left(\mathrm{CH}_{2}\right)_{2} \mathrm{CH}\left(\mathrm{NH}_{2}\right) \mathrm{CO}_{2} \mathrm{H} \\
\mathrm{C}_{3} \mathrm{H}_{5}(\mathrm{OH})_{3}\end{array}$ & 267 \\
\hline Glycolic Acid & $\mathrm{HOCH}_{2} \mathrm{CO}_{2} \mathrm{H}$ & 466 \\
\hline Halothane & $\mathrm{CF}_{3} \mathrm{CBrCl}$ & 58,61 \\
\hline $\begin{array}{l}\text { HCFC or HFC } \\
\text { Heparin }\end{array}$ & & $467, \mathrm{~g} 652, \mathrm{~g} 653$ \\
\hline Heptanal & $\mathrm{C}_{6} \mathrm{H}_{13} \mathrm{CHO}$ & \\
\hline Hexafluorobenzene & $\mathrm{C}_{6} \mathrm{~F}_{6}$ & \\
\hline Hexafluoropropene & $\mathrm{CF}_{2} \mathrm{CFCF}_{3}$ & \\
\hline HMX & $\left(\mathrm{CH}_{2}\right)_{4}\left(\mathrm{NNO}_{2}\right)_{4}$ & \\
\hline Hexanol & $\mathrm{C}_{6} \mathrm{H}_{13} \mathrm{OH}$ & \\
\hline L-Histidine & $\mathrm{C}_{3} \mathrm{~N}_{2} \mathrm{H}_{3} \mathrm{CH}_{2} \mathrm{CH}\left(\mathrm{NH}_{2}\right) \mathrm{CO}_{2} \mathrm{H}$ & 267 \\
\hline Humic Acids & & $63,66,178,794$ \\
\hline Hydroxybenzoic acid (various) & $\mathrm{HOC}_{6} \mathrm{H}_{4}(\mathrm{OH}) \mathrm{CO}_{2} \mathrm{H}$ & \\
\hline Hydroxycarboxylic acids, alpha & $\mathrm{RCH}(\mathrm{OH}) \mathrm{CO}_{2} \mathrm{H}$ & \\
\hline Hydroxyethylcellulose & & \\
\hline Imidacloprid & & 3 \\
\hline Imidazole & $\mathrm{C}_{3} \mathrm{H}_{4} \mathrm{~N}_{2}$ & 541 \\
\hline Indole & $\mathrm{C}_{8} \mathrm{H}_{6} \mathrm{NH}$ & g582,615 \\
\hline
\end{tabular}


Table 2. Other Organic Compounds Treated by a Photocatalytic Process

\begin{tabular}{|c|c|c|}
\hline Substance & Formula & Reference \\
\hline Iprobenfos & & 254 \\
\hline Isobutane & $\mathrm{C}_{4} \mathrm{H}_{10}$ & \\
\hline Isobutanol & $\mathrm{CH}_{3} \mathrm{CH}\left(\mathrm{CH}_{3}\right) \mathrm{CH}_{2} \mathrm{OH}$ & \\
\hline Isobutene & $\mathrm{C}_{4} \mathrm{H}_{8}$ & \\
\hline Isobutyric Acid & $\mathrm{CH}_{3} \mathrm{CH}\left(\mathrm{CH}_{3}\right) \mathrm{CO}_{2} \mathrm{H}$ & \\
\hline L-iso-Lucine & $\mathrm{C}_{2} \mathrm{H}_{5} \mathrm{CH}\left(\mathrm{CH}_{3}\right) \mathrm{CH}\left(\mathrm{NH}_{2}\right) \mathrm{CO}_{2} \mathrm{H}$ & 267 \\
\hline Isonicotinaldehyde & $\mathrm{C}_{5} \mathrm{H}_{4} \mathrm{NCHO}$ & \\
\hline Isoprene & $\mathrm{CH}_{2} \mathrm{C}\left(\mathrm{CH}_{3}\right) \mathrm{CHCH}_{2}$ & g325 \\
\hline Isoprothiolane & & 254 \\
\hline Isosorbide dinitrate & $\mathrm{C}_{6} \mathrm{O}_{2} \mathrm{H}_{8}\left(\mathrm{ONO}_{2}\right)_{2}$ & \\
\hline Iso-octane & $\left(\mathrm{CH}_{3}\right)_{2} \mathrm{CH}\left(\mathrm{CH}_{2}\right)_{4} \mathrm{CH}_{3}$ & \\
\hline L-Lysine & $\mathrm{NH}_{2}\left(\mathrm{CH}_{2}\right)_{4} \mathrm{CH}\left(\mathrm{NH}_{2}\right) \mathrm{CO}_{2} \mathrm{H}$ & 563 \\
\hline Lactic acid & $\mathrm{C}_{3} \mathrm{H}_{6} \mathrm{O}_{3}$ & 47 \\
\hline Landfill leachate & & \\
\hline Lignin & & 120 \\
\hline Limonene & $\mathrm{C}_{9} \mathrm{H}_{16}$ & g325 \\
\hline Linoleic acid & $\mathrm{C}_{18} \mathrm{H}_{31} \mathrm{CO}_{2} \mathrm{H}$ & 679 \\
\hline L-Leucine & $\left(\mathrm{CH}_{3}\right)_{2} \mathrm{CHCH}_{2} \mathrm{CH}\left(\mathrm{NH}_{2}\right) \mathrm{CO}_{2} \mathrm{H}$ & 267 \\
\hline Luminol-CL & & 807 \\
\hline Malachite green oxalate & $\begin{array}{c}\left(\mathrm{C}_{6} \mathrm{H}_{5}\right)\left[\mathrm{C}_{6} \mathrm{H}_{4} \mathrm{~N}\left(\mathrm{CH}_{3}\right)_{2}\right]\left[\mathrm{C}_{6} \mathrm{H}_{4} \mathrm{~N}-\right. \\
\left.\left(\mathrm{CH}_{3}\right)_{2}\right] \mathrm{C},\left(\mathrm{C}_{2} \mathrm{O}_{4} \mathrm{H}\right)_{2} \cdot \mathrm{H}_{2} \mathrm{C}_{2} \mathrm{O}_{4}\end{array}$ & \\
\hline Maleic acid & $\mathrm{HO}_{2} \mathrm{CCHCHCO}_{2} \mathrm{H}$ & 121 \\
\hline Maleic anhydride & $\mathrm{O}_{2} \mathrm{CCHCHCO}_{2}$ & 121,123 \\
\hline Malic acid & $\mathrm{HO}_{2} \mathrm{CCH}_{2} \mathrm{CH}(\mathrm{OH}) \mathrm{CO}_{2} \mathrm{H}$ & 262 \\
\hline Malonaldehyde & $\mathrm{H}(\mathrm{O}) \mathrm{CCH}_{2} \mathrm{C}(\mathrm{O}) \mathrm{H}$ & 459 \\
\hline Malonic acid & $\mathrm{CH}_{2}\left(\mathrm{CO}_{2} \mathrm{H}\right)_{2}$ & 654 \\
\hline Manitol & $\mathrm{HOCH}_{2}[\mathrm{CH}(\mathrm{OH})]_{4} \mathrm{CH}_{2} \mathrm{OH}$ & 356 \\
\hline Mercaptotetrazole & $\mathrm{HSN}_{4} \mathrm{H}$ & 776 \\
\hline Mesitylene & $\left(\mathrm{CH}_{3}\right)_{3} \mathrm{C}_{6} \mathrm{H}_{3}$ & g394 \\
\hline Methane & $\mathrm{CH}_{4}$ & g172,g564 \\
\hline Methanethiol & $\mathrm{CH}_{3} \mathrm{SH}$ & 717 \\
\hline L-Methionine & $\mathrm{CH}_{3} \mathrm{~S}\left(\mathrm{CH}_{2}\right)_{2} \mathrm{CH}\left(\mathrm{NH}_{2}\right) \mathrm{CO}_{2} \mathrm{H}$ & 267 \\
\hline Methomyl & & 846 \\
\hline $\begin{array}{l}\text { N-Methylaniline } \\
\text { Methylcyclohexane } \\
\text { Methyl-2-naphthoate }\end{array}$ & $\begin{array}{l}\mathrm{C}_{6} \mathrm{H}_{5} \mathrm{NHCH}_{3} \\
\mathrm{CH}_{3} \mathrm{C}_{6} \mathrm{H}_{11} \\
\mathrm{C}_{10} \mathrm{H}_{7} \mathrm{CO}_{2} \mathrm{CH}_{3}\end{array}$ & $\begin{array}{l}275 \\
754\end{array}$ \\
\hline Methylnitrophos & & 138 \\
\hline Methyl orange & $\mathrm{Na}, \mathrm{O}_{3} \mathrm{SC}_{6} \mathrm{H}_{4} \mathrm{~N}_{2} \mathrm{C}_{6} \mathrm{H}_{4} \mathrm{~N}\left(\mathrm{CH}_{3}\right)_{2}$ & $\begin{array}{l}450,784,785,786,787,788 \\
851\end{array}$ \\
\hline alpha-Methylstyrene & $\mathrm{C}_{6} \mathrm{H}_{5}\left(\mathrm{CH}_{3}\right) \mathrm{CCH}_{2}$ & \\
\hline Methyl viologen & $\left(\mathrm{CH}_{3} \mathrm{C}_{5} \mathrm{H}_{4} \mathrm{~N}\right)_{2}, \mathrm{Cl}_{2}$ & $55,58,61,386,432$ \\
\hline Methylene blue & $\left(\mathrm{CH}_{3}\right)_{2} \mathrm{NC}_{6} \mathrm{H}_{3} \mathrm{NSC}_{6} \mathrm{H}_{3} \mathrm{~N}\left(\mathrm{CH}_{3}\right)_{2}, \mathrm{Cl}$ & $\begin{array}{l}40,144,479,513,522,671 \\
691,774\end{array}$ \\
\hline Methylvinylketone & $\mathrm{CH}_{3} \mathrm{COC}_{2} \mathrm{H}_{3}$ & \\
\hline Microcystin-LR or YR or YA & & $188,633,634,702$ \\
\hline Mixed waste & & \\
\hline
\end{tabular}


Table 2. Other Organic Compounds Treated by a Photocatalytic Process

\begin{tabular}{|c|c|c|}
\hline Substance & Formula & Reference \\
\hline \multicolumn{3}{|l|}{$\overline{\text { Molasses }}$} \\
\hline Monocrotophos & & 137,379 \\
\hline Monuron & $\mathrm{ClC}_{6} \mathrm{H}_{4} \mathrm{NHCON}\left(\mathrm{CH}_{3}\right)_{2}$ & \\
\hline Morpholine & $\mathrm{C}_{4} \mathrm{H}_{8} \mathrm{ONH}$ & \\
\hline Myrcene & $\mathrm{C}_{10} \mathrm{H}_{16}$ & g325 \\
\hline m-Phenoxytoluene & $\mathrm{m}-\mathrm{C}_{6} \mathrm{H}_{5} \mathrm{O}-\mathrm{C}_{6} \mathrm{H}_{4} \mathrm{CH}_{3}$ & \\
\hline N-Benzyldiphenylamine & $\left(\mathrm{C}_{6} \mathrm{H}_{5} \mathrm{CH}_{2}\right)\left(\mathrm{C}_{6} \mathrm{H}_{5}\right)_{2} \mathrm{~N}$ & \\
\hline N-Docanoyl-beta-alanine & & 267 \\
\hline $\mathrm{N}$-Dodecanoylglutamate & & 267 \\
\hline $\begin{array}{l}\text { N'-Dodecyl-N,N-dimethyl ammonium- } \\
\text { acetate, sodium salt }\end{array}$ & & 270 \\
\hline $\begin{array}{l}\text { N'-Dodecylamidopropyl-N,N-dimethyl- } \\
\text { ammonium acetate, sodium salt }\end{array}$ & & 270 \\
\hline $\mathrm{N}$-Dodecanoyl-N-(2-hydroxyethyl)amide & $\mathrm{CH}_{3}\left(\mathrm{CH}_{2}\right)_{10} \mathrm{C}(\mathrm{O}) \mathrm{NH}\left(\mathrm{CH}_{2}\right)_{2} \mathrm{OH}$ & 270 \\
\hline $\begin{array}{l}\text { N-Dodecanoyl-N,N-bis(2-hydroxyethyl)- } \\
\text { amide }\end{array}$ & $\mathrm{CH}_{3}\left(\mathrm{CH}_{2}\right)_{10} \mathrm{C}(\mathrm{O}) \mathrm{N}\left[\left(\mathrm{CH}_{2}\right)_{2} \mathrm{OH}_{2}\right.$ & \\
\hline $\mathrm{N}$-Hydroxysuccinimide & $\mathrm{C}_{2} \mathrm{H}_{4}(\mathrm{C}(\mathrm{O}))_{2} \mathrm{NOH}$ & \\
\hline N-Phenyl-1,4-phenylenediamine & $\mathrm{C}_{6} \mathrm{H}_{5} \mathrm{NHC}_{6} \mathrm{H}_{4} \mathrm{NH}_{2}$ & 275 \\
\hline \multicolumn{3}{|l|}{$\mathrm{N}, \mathrm{N}, \mathrm{N}^{\prime}, \mathrm{N}^{\prime}$-Tetraethyloxonine } \\
\hline alpha-Naphthaleneacetic acid & $\mathrm{C}_{10} \mathrm{H}_{7} \mathrm{CH}_{2} \mathrm{CO}_{2} \mathrm{H}$ & 855 \\
\hline Naphthol & $\mathrm{C}_{10} \mathrm{H}_{7} \mathrm{OH}$ & \\
\hline Naphthol blue black & $\begin{array}{l}\left(\mathrm{C}_{6} \mathrm{H}_{5} \mathrm{~N}_{2}\right) \mathrm{C}_{12} \mathrm{H}_{2}(\mathrm{OH})\left(\mathrm{NH}_{2}\right)^{-} \\
\left(\mathrm{SO}_{3} \mathrm{Na}\right)_{2}\end{array}$ & 523 \\
\hline Nicotinamide Coenzymes & & 92 \\
\hline Nicotine & $\mathrm{C}_{5} \mathrm{H}_{4} \mathrm{NC}_{4} \mathrm{H}_{7} \mathrm{NCH}_{3}$ & \\
\hline Nile Blue A & $\mathrm{C}_{16} \mathrm{NO}\left(\mathrm{NH}_{2}\right) \mathrm{N}\left(\mathrm{C}_{2} \mathrm{H}_{5}\right)_{2}, \mathrm{SO}_{4}$ & \\
\hline \multicolumn{3}{|l|}{ Nitrocellulose } \\
\hline o-Nitrophenyl-beta-D-galactopyranoside & $\mathrm{C}_{12} \mathrm{H}_{15} \mathrm{NO}_{8}$ & 301 \\
\hline Nitropropane & $\mathrm{CH}_{3} \mathrm{CH}_{2} \mathrm{CH}_{2} \mathrm{NO}_{2}$ & $190,191,192$ \\
\hline Nitrosobenzene & $\mathrm{ONC}_{6} \mathrm{H}_{5}$ & 588,589 \\
\hline p-Nitrosodimethylanaline & $\mathrm{ONC}_{6} \mathrm{H}_{4} \mathrm{~N}\left(\mathrm{CH}_{3}\right)_{2}$ & 424 \\
\hline p-Nitrotoluenesulfonic acid & $\left(\mathrm{CH}_{3}\right)\left(\mathrm{NO}_{2}\right) \mathrm{C}_{6} \mathrm{H}_{3} \mathrm{SO}_{3} \mathrm{H}$ & \\
\hline Nitrotoluene, various & $\mathrm{NO}_{2} \mathrm{C}_{6} \mathrm{H}_{4} \mathrm{CH}_{3}$ & \\
\hline Nonylphenylethoxylate & $\mathrm{C}_{9} \mathrm{H}_{17} \mathrm{C}_{6} \mathrm{H}_{4} \mathrm{OC}_{2} \mathrm{H}_{5}$ & \\
\hline n-Nonylphenylpolyoxyethylene ethers & $\mathrm{C}_{9} \mathrm{H}_{17} \mathrm{C}_{6} \mathrm{H}_{4} \mathrm{O}\left(\mathrm{C}_{2} \mathrm{H}_{4} \mathrm{O}\right)_{\mathrm{n}} \mathrm{H}$ & 268,850 \\
\hline n-Octanoic acid & $\mathrm{C}_{7} \mathrm{H}_{15} \mathrm{CO}_{2} \mathrm{H}$ & 665 \\
\hline n-Octanol & $\mathrm{C}_{8} \mathrm{H}_{17} \mathrm{OH}$ & 311,820 \\
\hline $\begin{array}{l}\text { Octanal } \\
\text { Octaphenylcyclotetrasiloxane }\end{array}$ & $\begin{array}{l}\mathrm{C}_{7} \mathrm{H}_{15} \mathrm{CHO} \\
\left(\mathrm{C}_{6} \mathrm{H}_{5}\right)_{8}\left(\mathrm{SiO}_{2}\right)_{4}\end{array}$ & \\
\hline Oil/Petroleum & & $249,342,498,499$ \\
\hline Oxalic acid or oxalate ion & $\mathrm{C}_{2} \mathrm{O}_{4} \mathrm{H}_{2}$ & $\begin{array}{l}108,193,278,416,590,654 \\
740\end{array}$ \\
\hline \multicolumn{3}{|l|}{ PCB - polyhydroxy } \\
\hline Pendimethalin & & \\
\hline Pentachloroethane & $\mathrm{C}_{2} \mathrm{HCl}_{5}$ & 305 \\
\hline Pentaethyleneglycol n-dodecyl ether & $(\mathrm{HO})\left(\mathrm{CH}_{2} \mathrm{CH}_{2} \mathrm{O}\right)_{5}\left(\mathrm{C}_{12} \mathrm{H}_{23}\right)$ & \\
\hline
\end{tabular}


Table 2. Other Organic Compounds Treated by a Photocatalytic Process

\begin{tabular}{|c|c|c|}
\hline Substance & Formula & Reference \\
\hline Pentafluorophenol & $\mathrm{C}_{6} \mathrm{~F}_{5} \mathrm{OH}$ & \\
\hline n-Pentyl amine & $n-C_{5} \mathrm{H}_{11} \mathrm{NH}_{2}$ & \\
\hline \multicolumn{3}{|l|}{ Permethrin } \\
\hline Pesticides - unspecified & & 137,142 \\
\hline beta-Phellandrene & & g325 \\
\hline Phenacylstyrylthioether & $\mathrm{C}_{6} \mathrm{H}_{5} \mathrm{CH}_{2} \mathrm{SCH}_{2} \mathrm{C}\left(\mathrm{C}_{6} \mathrm{H}_{5}\right) \mathrm{CH}_{2}$ & \\
\hline Phenosafranin & $\mathrm{C}_{6} \mathrm{H}_{5} \mathrm{~N}_{2} \mathrm{C}_{12} \mathrm{H}_{4}\left(\mathrm{NH}_{2}\left(\mathrm{CH}_{3}\right)_{2}\right.$ & \\
\hline Phenoxyacetic acid & $\mathrm{C}_{6} \mathrm{H}_{5} \mathrm{OCH}_{2} \mathrm{CO}_{2} \mathrm{H}$ & 689,752 \\
\hline Phenylacetic acid & $\mathrm{C}_{6} \mathrm{H}_{5} \mathrm{CH}_{2} \mathrm{CO}_{2} \mathrm{H}$ & 689 \\
\hline L-Phenylalanine & $\mathrm{C}_{6} \mathrm{H}_{5} \mathrm{CH}_{2} \mathrm{CH}\left(\mathrm{NH}_{2}\right) \mathrm{CO}_{2} \mathrm{H}$ & $267,288,344$ \\
\hline Phenylsulfinylacetic acid & $\mathrm{C}_{6} \mathrm{H}_{5} \mathrm{~S}(\mathrm{O}) \mathrm{CH}_{2} \mathrm{CO}_{2} \mathrm{H}$ & 689 \\
\hline Phenylsulfonylacetic acid & $\mathrm{C}_{6} \mathrm{H}_{5} \mathrm{~S}(\mathrm{O})_{2} \mathrm{CH}_{2} \mathrm{CO}_{2} \mathrm{H}$ & 689 \\
\hline Phenylthioacetic acid & $\mathrm{C}_{6} \mathrm{H}_{5} \mathrm{SCH}_{2} \mathrm{CO}_{2} \mathrm{H}$ & 689 \\
\hline p-Phenylenediamine & $\mathrm{H}_{2} \mathrm{NC}_{6} \mathrm{H}_{4} \mathrm{NH}_{2}$ & \\
\hline Phenylhydroxylamine & $\mathrm{C}_{6} \mathrm{H}_{5} \mathrm{NHOH}$ & 588,589 \\
\hline Phenylmercaptotetrazole & $\mathrm{C}_{6} \mathrm{H}_{5} \mathrm{SN}_{4} \mathrm{H}$ & 776 \\
\hline Phenyltetrazole & $\mathrm{C}_{6} \mathrm{H}_{5} \mathrm{~N}_{4} \mathrm{H}$ & 776 \\
\hline Phorate & $\left(\mathrm{C}_{2} \mathrm{H}_{5} \mathrm{O}\right) \mathrm{P}(\mathrm{S}) \mathrm{SCH}_{2} \mathrm{SC}_{2} \mathrm{H}_{5}$ & 137 \\
\hline Phthaldialdehyde & $\mathrm{C}_{6} \mathrm{H}_{4}(\mathrm{CHO})_{2}$ & \\
\hline \multicolumn{3}{|l|}{ Phthalan } \\
\hline Phthalic acid & $\mathrm{C}_{6} \mathrm{H}_{4}\left(\mathrm{CO}_{2} \mathrm{H}\right)_{2}$ & 741 \\
\hline Phthalazinylhydrazones & & 576 \\
\hline Picoline & $\mathrm{CH}_{3} \mathrm{C}_{5} \mathrm{H}_{4} \mathrm{~N}$ & \\
\hline Pinene (alpha or beta) & $\mathrm{C}_{10} \mathrm{H}_{16}$ & g196,g325,g590 \\
\hline Piperidene & $\mathrm{C}_{5} \mathrm{H}_{10} \mathrm{NH}$ & \\
\hline Polyethoxylene alkyl ethers & $\mathrm{R}_{2}\left(\mathrm{OC}_{2} \mathrm{H}_{4}\right) \mathrm{n}$ & 551 \\
\hline Polyethylene & $\left(\mathrm{CH}_{2} \mathrm{CH}_{2}\right) \mathrm{n}$ & \\
\hline Poly(methylphenylsiloxane) & {$\left[\left(\mathrm{C}_{6} \mathrm{H}_{5}\right)\left(\mathrm{CH}_{3}\right) \mathrm{SiO}\right] \mathrm{n}$} & \\
\hline Polypropylene & {$\left[\left(\mathrm{CH}_{3}\right) \mathrm{CHCH}_{2}\right]_{\mathrm{n}}$} & 12,391 \\
\hline Polyvinylalcohol & $\left(\mathrm{C}_{2} \mathrm{H}_{3} \mathrm{OH}\right) \mathrm{n}$ & 55,58 \\
\hline Polyvinylchloride (PVC) & $\left(\mathrm{CH}_{2} \mathrm{CHCl}\right) \mathrm{n}$ & 287 \\
\hline Procion red & & 332 \\
\hline Procymidone & & 308 \\
\hline L-Proline & $\mathrm{C}_{4} \mathrm{H}_{8} \mathrm{NCO}_{2} \mathrm{H}$ & 267 \\
\hline \multicolumn{3}{|l|}{ Prometon } \\
\hline Prometryn & & 501 \\
\hline Propane & $\mathrm{C}_{3} \mathrm{H}_{8}$ & 831 \\
\hline Propanil & $\left(3,4-\mathrm{Cl}_{2} \mathrm{C}_{6} \mathrm{H}_{3}\right) \mathrm{NH}(\mathrm{O}) \mathrm{CC}_{2} \mathrm{H}_{5}$ & 705 \\
\hline Propazine & & 501 \\
\hline Propionamide & $\mathrm{CH}_{3} \mathrm{CH}_{2} \mathrm{C}(\mathrm{O}) \mathrm{NH}_{2}$ & \\
\hline Propionic acid & $\mathrm{C}_{2} \mathrm{H}_{5} \mathrm{CO}_{2} \mathrm{H}$ & \\
\hline Propyzamide & & $254,725,828$ \\
\hline Propylene & $\mathrm{C}_{3} \mathrm{H}_{6}$ & \\
\hline Propylene glycol & $\mathrm{CH}_{3} \mathrm{CH}(\mathrm{OH}) \mathrm{CH}_{2} \mathrm{OH}$ & 170,361 \\
\hline Propylene glycol dinitrate & $\mathrm{CH}_{3} \mathrm{CH}\left(\mathrm{NO}_{3}\right) \mathrm{CH}_{2}\left(\mathrm{NO}_{3}\right)$ & \\
\hline
\end{tabular}


Table 2. Other Organic Compounds Treated by a Photocatalytic Process

\begin{tabular}{|c|c|c|}
\hline Substance & Formula & Reference \\
\hline Propyne & $\mathrm{CH}_{3} \mathrm{CCH}$ & \\
\hline Propyzamide & & \\
\hline Pyridine & $\mathrm{C}_{5} \mathrm{H}_{5} \mathrm{~N}$ & \\
\hline Pyrocatechol & $\mathrm{o}-\mathrm{C}_{6} \mathrm{H}_{4}(\mathrm{OH})_{2}$ & \\
\hline Pyrrole & $\mathrm{C}_{4} \mathrm{H}_{5} \mathrm{~N}$ & g582 \\
\hline Quinoline acid yellow & & \\
\hline Reactive Dyes & & $616,617,627$ \\
\hline Reactive Red M5B & & 529 \\
\hline Red Dye 79 & & \\
\hline Red Dye 4BS & & 140 \\
\hline Resorcinol & $\mathrm{C}_{6} \mathrm{H}_{6} \mathrm{O}_{2}$ & $93,94,601,602,761$ \\
\hline RDX, see cyclonite & $\left(\mathrm{CH}_{2}\right)_{3}\left(\mathrm{NNO}_{2}\right)_{3}$ & \\
\hline Rhodamine B & $\mathrm{CH}_{3} \mathrm{OC}(\mathrm{O})\left(\mathrm{C}_{6} \mathrm{H}_{4}\right) \mathrm{C}_{13} \mathrm{H}_{6} \mathrm{O}\left(\mathrm{NH}_{2}\right)_{2}$ & $440,441,474,499,606,849$ \\
\hline Rhodamine 6G & $\begin{array}{l}\mathrm{C}_{2} \mathrm{H}_{5} \mathrm{OC}(\mathrm{O}) \mathrm{C}_{6} \mathrm{H}_{4} \mathrm{C}_{13} \mathrm{H}_{4}\left(\mathrm{CH}_{3}\right)_{2^{-}} \\
{\left[\mathrm{N}\left(\mathrm{C}_{2} \mathrm{H}_{5}\right)\right]_{2}, \mathrm{Cl}}\end{array}$ & 39 \\
\hline Rhodamine $6 \mathrm{ZH}$ & & \\
\hline Rose Bengal & $\mathrm{Na}_{2}, \mathrm{O}_{2} \mathrm{CC}_{6} \mathrm{Cl}_{4} \mathrm{C}_{13} \mathrm{H}_{2} \mathrm{Ol}_{4} \mathrm{O}_{2}$ & \\
\hline S-Dodecyl thioether carboxylates & & \\
\hline $\begin{array}{l}\text { S-Ethyl-N,N-dipropyl thiocarbamate } \\
\text { (EPTC) }\end{array}$ & $\left(\mathrm{C}_{2} \mathrm{H}_{5}\right) \mathrm{SC}(\mathrm{O}) \mathrm{N}\left(\mathrm{C}_{3} \mathrm{H}_{7}\right)_{2}$ & \\
\hline $\begin{array}{l}\text { S-Ethyl-N,N-diisopropylthiocarbamate } \\
\text { (Butylate) }\end{array}$ & $\left(\mathrm{C}_{2} \mathrm{H}_{5}\right) \mathrm{SC}(\mathrm{O}) \mathrm{N}\left(\mathrm{i}-\mathrm{C}_{3} \mathrm{H}_{7}\right)_{2}$ & \\
\hline $\begin{array}{l}\text { S-Ethyl-4-hexahydro-1-H-azepine-1- } \\
\text { carbothionate (molinate) }\end{array}$ & & \\
\hline $\begin{array}{l}\text { S-Propyl-N-cyclohexyl thiocarbamate } \\
\text { (cycloate) }\end{array}$ & $\left(\mathrm{C}_{3} \mathrm{H}_{7}\right) \mathrm{SC}(\mathrm{O}) \mathrm{NH}\left(\mathrm{C}_{6} \mathrm{H}_{11}\right)$ & \\
\hline $\begin{array}{l}\text { S-Propyl-N,N-dipropyl thiocarbamate } \\
\text { (vernolate) }\end{array}$ & $\left(\mathrm{C}_{3} \mathrm{H}_{7}\right) \mathrm{SC}(\mathrm{O})\left(\mathrm{NC}_{3} \mathrm{H}_{7}\right)_{2}$ & 767,768 \\
\hline Sabinine & & g325 \\
\hline Salicylaldehyde & $\mathrm{C}_{7} \mathrm{H}_{6} \mathrm{O}_{2}$ & \\
\hline Salicylic acid & $\mathrm{C}_{7} \mathrm{H}_{6} \mathrm{O}_{3}$ & $\begin{array}{l}197,245,278,392,411,451 \\
572,573,614,713,758\end{array}$ \\
\hline L-Serine & $\mathrm{HOCH}_{2} \mathrm{CH}\left(\mathrm{NH}_{2}\right) \mathrm{CO}_{2} \mathrm{H}$ & 267,288 \\
\hline Simazine & $\left(\mathrm{C}_{2} \mathrm{H}_{5}\right) \mathrm{Cl}\left(\mathrm{NHC}_{2} \mathrm{H}_{5}\right) \mathrm{C}_{3} \mathrm{~N}_{3}$ & 254 \\
\hline Sodium chloroacetate & $\mathrm{CH}_{3} \mathrm{CO}_{2} \mathrm{Na}$ & \\
\hline Sodium dodecylbenzene sulfonate & $\mathrm{C}_{12} \mathrm{H}_{25} \mathrm{C}_{6} \mathrm{H}_{4} \mathrm{SO}_{3} \mathrm{Na}$ & \\
\hline Special brilliant blue FFR & & 43 \\
\hline Stearic acid & $\mathrm{CH}_{3}\left(\mathrm{CH}_{2}\right)_{16} \mathrm{CO}_{2} \mathrm{H}$ & 659 \\
\hline Stilbene & $\mathrm{C}_{6} \mathrm{H}_{5} \mathrm{CHCHC}_{6} \mathrm{H}_{5}$ & \\
\hline Succinic acid & $\mathrm{HO}_{2} \mathrm{CCH}_{2} \mathrm{CH}_{2} \mathrm{CO}_{2} \mathrm{H}$ & 319 \\
\hline Succinimide & $\mathrm{HNC}(\mathrm{O}) \mathrm{CH}_{2} \mathrm{CH}_{2} \mathrm{C}(\mathrm{O})$ & 541 \\
\hline Sucrose & $\mathrm{C}_{12} \mathrm{H}_{22} \mathrm{O}_{11}$ & 74 \\
\hline Sulfones & $\mathrm{RS}(\mathrm{O})_{2} \mathrm{R}^{\prime}$ & \\
\hline Superoxide dismutase (SOD) & & 318 \\
\hline Surfactants - unspecified & & 129 \\
\hline Tartaric acid & $\mathrm{HO}_{2} \mathrm{CCH}(\mathrm{OH}) \mathrm{CH}(\mathrm{OH}) \mathrm{CO}_{2} \mathrm{H}$ & 654 \\
\hline
\end{tabular}


Table 2. Other Organic Compounds Treated by a Photocatalytic Process

\begin{tabular}{|c|c|c|}
\hline Substance & Formula & Reference \\
\hline Terbutryne & & 435 \\
\hline Terpinene & $\mathrm{C}_{10} \mathrm{H}_{16}$ & g325 \\
\hline alpha-Terpineol & $\mathrm{C}_{10} \mathrm{H}_{18} \mathrm{O}$ & 39 \\
\hline Tetrachloroaniline & $\mathrm{Cl}_{4} \mathrm{C}_{6} \mathrm{HNH}_{2}$ & 275 \\
\hline Tetrachlorvinphos & $\mathrm{CHClCH}\left(2,4,5-\mathrm{Cl}_{3} \mathrm{C}_{6} \mathrm{H}_{2}\right)\left(\mathrm{CH}_{3}\right) \mathrm{PO}_{4}$ & \\
\hline Tetrafluoroethylene & $\mathrm{C}_{2} \mathrm{~F}_{4}$ & \\
\hline Tetralin & $\mathrm{C}_{10} \mathrm{H}_{12}$ & \\
\hline Tetramethylenediamine & $\mathrm{NH}_{2}\left(\mathrm{CH}_{2}\right)_{4} \mathrm{NH}_{2}$ & \\
\hline Tetrabutylammonium phosphate & {$\left[\left(\mathrm{n}-\mathrm{C}_{4} \mathrm{H}_{9}\right)_{4} \mathrm{~N}\right]_{4}, \mathrm{PO}_{4}$} & \\
\hline $\begin{array}{l}\text { Tetradecyldimethylbenzylammonium- } \\
\text { chloride }\end{array}$ & $\mathrm{CH}_{3}\left(\mathrm{CH}_{2}\right)_{13}\left(\mathrm{CH}_{3}\right)_{2}\left(\mathrm{C}_{6} \mathrm{H}_{5} \mathrm{CH}_{2}\right) \mathrm{N}, \mathrm{Cl}$ & \\
\hline Tetranitromethane & $\mathrm{C}\left(\mathrm{NO}_{2}\right)_{4}$ & $58,87,495$ \\
\hline Theophylline & $\mathrm{C}_{7} \mathrm{H}_{8} \mathrm{~N}_{4} \mathrm{O}_{2} \cdot \mathrm{H}_{2} \mathrm{O}$ & \\
\hline Thianthrene & $\mathrm{C}_{13} \mathrm{H}_{8} \mathrm{OS}$ & 1 \\
\hline Thioethers & RSR' & \\
\hline Thiobencarb & & \\
\hline Thiolactic acid & $\mathrm{CH}_{3} \mathrm{CH}(\mathrm{SH}) \mathrm{CO}_{2} \mathrm{H}$ & 132,133 \\
\hline Thiophenol & $\mathrm{C}_{6} \mathrm{H}_{5} \mathrm{SH}$ & 278 \\
\hline Thioxanthene & $\mathrm{C}_{12} \mathrm{H}_{8} \mathrm{~S}_{2}$ & 1 \\
\hline Thioxanthone & $\mathrm{C}_{13} \mathrm{H}_{8} \mathrm{OS}$ & 1 \\
\hline Thiram & & 254 \\
\hline Thymine & $\mathrm{C}_{5} \mathrm{H}_{6} \mathrm{~N}_{2} \mathrm{O}_{2}$ & \\
\hline Thionine & $\mathrm{C}_{12} \mathrm{NS}\left(\mathrm{NH}_{2}\right), \mathrm{O}_{2} \mathrm{CCH}_{3}$ & \\
\hline L-Threonine & $\mathrm{CH}_{3} \mathrm{CH}(\mathrm{OH}) \mathrm{CH}\left(\mathrm{NH}_{2}\right) \mathrm{CO}_{2} \mathrm{H}$ & 267 \\
\hline p-Toluenesulfonic acid & $\mathrm{CH}_{3} \mathrm{C}_{6} \mathrm{H}_{4} \mathrm{SO}_{3} \mathrm{H}$ & \\
\hline p-Toluidine & $\mathrm{CH}_{3} \mathrm{C}_{6} \mathrm{H}_{4} \mathrm{NH}_{2}$ & 600 \\
\hline Total Organic Carbon (TOC) & & $52,53,94,167,168,199$ \\
\hline s-Triazines & & $\begin{array}{l}249,322,401,434,460,461, L \\
62,583,584,585 \\
68,71,475\end{array}$ \\
\hline Trichloroacetic acid & $\mathrm{Cl}_{3} \mathrm{CCO}_{2} \mathrm{H}$ & $145,146,227$ \\
\hline Trietazine & & \\
\hline Triethanolamine & $\mathrm{N}\left(\mathrm{CH}_{2} \mathrm{CH}_{2} \mathrm{OH}\right)_{3}$ & \\
\hline Trifluoroacetic acid & $\mathrm{CF}_{3} \mathrm{CO}_{2} \mathrm{H}$ & \\
\hline Trihydrazinotriazine & & \\
\hline Trihydroxybenzene & $(\mathrm{HO})_{3} \mathrm{C}_{6} \mathrm{H}_{3}$ & \\
\hline Trimethylamine & $\left(\mathrm{CH}_{3}\right)_{3} \mathrm{~N}$ & g328 \\
\hline Trimethylammonium chloride & $\left(\mathrm{CH}_{3}\right)_{3} \mathrm{NH}, \mathrm{Cl}$ & 212 \\
\hline Trinitrophenol & $\left(\mathrm{NO}_{2}\right)_{3} \mathrm{C}_{6} \mathrm{H}_{2} \mathrm{OH}$ & \\
\hline Triphenylacetic acid & $\left(\mathrm{C}_{6} \mathrm{H}_{5}\right)_{3} \mathrm{CCO}_{2} \mathrm{H}$ & \\
\hline Triphenylbismuthine & $\left(\mathrm{C}_{6} \mathrm{H}_{5}\right)_{3} \mathrm{Bi}$ & \\
\hline Triphenylphosphine & $\left(\mathrm{C}_{6} \mathrm{H}_{5}\right)_{3} \mathrm{P}$ & \\
\hline Triphenylstibine & $\left(\mathrm{C}_{6} \mathrm{H}_{5}\right)_{3} \mathrm{Sb}$ & \\
\hline L-Tryptophan & $\mathrm{C}_{8} \mathrm{NH}_{6} \mathrm{CH}_{2} \mathrm{CH}(\mathrm{NH}) \mathrm{CO}_{2} \mathrm{H}$ & 267 \\
\hline Tri-(p-Tolyl)arsine & $\left(\mathrm{CH}_{3} \mathrm{C}_{6} \mathrm{H}_{4}\right)_{3} \mathrm{As}$ & \\
\hline Triton $\mathrm{X}-100$ & $\mathrm{C}_{8} \mathrm{H}_{17} \mathrm{C}_{6} \mathrm{H}_{4}\left(\mathrm{OCH}_{2} \mathrm{CH}_{2}\right)_{\mathrm{x}} \mathrm{OH}$ & \\
\hline
\end{tabular}


Table 2. Other Organic Compounds Treated by a Photocatalytic Process

\begin{tabular}{l|l|l}
\hline Substance & Formula & Reference \\
\hline \hline Umbelliferone & $\mathrm{C}_{9} \mathrm{H}_{6} \mathrm{O}_{3}$ & \\
Uracil & $\mathrm{HNC}(\mathrm{O}) \mathrm{NHC}(\mathrm{O}) \mathrm{CHCH}$ & 766 \\
Urea & $\mathrm{C}(\mathrm{O})\left(\mathrm{NH}_{2}\right)_{2}$ & 541 \\
L-Valine & $\left(\mathrm{CH}_{3}\right)_{2} \mathrm{CHCH}\left(\mathrm{NH}_{2}\right) \mathrm{CO}_{2} \mathrm{H}$ & 267 \\
Vat Blue & & 710 \\
Vinclozolin & & 308 \\
\hline
\end{tabular}


Table 3. Inorganic Substances Included in EPA Lists of Hazardous Substances and/or Treated by a Photocatalytic Process

\begin{tabular}{|c|c|c|}
\hline Substance/Element & Formula/Symbol & Reference \\
\hline Actinides & Th,Pa,U,Np,Pu & 124,180 \\
\hline Aluminum (fume or dust) & Al & \\
\hline Aluminum oxide & $\mathrm{Al}_{2} \mathrm{O}_{3}$ & \\
\hline Ammonia & $\mathrm{NH}_{3}$ & $\begin{array}{l}95,96, \mathrm{~g} 213, \mathrm{~g} 214, \mathrm{~g} 215 \\
476,541,588,589, \mathrm{~g} 747\end{array}$ \\
\hline Ammonium nitrate (soln) & $\mathrm{NH}_{4} \mathrm{NO}_{3}$ & \\
\hline Ammonium sulfate (soln) & $\left(\mathrm{NH}_{4}\right)_{2} \mathrm{SO}_{4}$ & \\
\hline Antimony & $\mathrm{Sb}$ & \\
\hline Arsenic & As & 194,419 \\
\hline Asbestos & Mg,Si & \\
\hline Azide ion & $\mathrm{N}_{3}^{(-)}$ & \\
\hline Barium & $\mathrm{Ba}$ & \\
\hline Beryllium & $\mathrm{Be}$ & \\
\hline Bismuth & $\mathrm{Bi}$ & \\
\hline Boron & B & \\
\hline Bromate ion & $\mathrm{BrO}_{3}(-1)$ & 489 \\
\hline Cadmium & $\mathrm{Cd}$ & $\begin{array}{l}442,443,593,594,595,596 \\
746\end{array}$ \\
\hline Chlorine & $\mathrm{Cl}$ & \\
\hline Chlorine dioxide & $\mathrm{ClO}_{2}$ & \\
\hline Chromium & $\mathrm{Cr}$ & $\begin{array}{l}157,201,202,203,204,205 \\
355,357,431,450,462,526 \\
593,594,595,596\end{array}$ \\
\hline Cobalt & Co & \\
\hline Copper & $\mathrm{Cu}$ & $\begin{array}{l}132,133,442,443,480,593 \\
594,595,596,609\end{array}$ \\
\hline Cyanide and Complexes & $\mathrm{CN}(-1)$ and $\mathrm{M}(\mathrm{CN})_{\mathrm{x}}$ & $45,120,444,492,509,596$ \\
\hline Cyanate ion & $\mathrm{CNO}(-1)$ & \\
\hline Gold & $A u$ & 596,774 \\
\hline Halide ion & $\mathrm{X}(1-), \mathrm{X}=\mathrm{F}, \mathrm{Cl}, \mathrm{Br}$, or I & 278,513 \\
\hline Hydrazine & $\mathrm{H}_{2} \mathrm{NNH}_{2}$ & \\
\hline Hydrogen sulfide & $\mathrm{H}_{2} \mathrm{~S}$ & 717 \\
\hline Hydroxylamine & $\mathrm{NH}_{2} \mathrm{OH}$ & 541 \\
\hline Hypophosphorus acid & $\mathrm{H}_{2} \mathrm{PO}_{2}$ & \\
\hline Iridium & Ir & \\
\hline Iron & $\mathrm{Fe}$ & \\
\hline Lead & $\mathrm{Pb}$ & $442,443,486,740,746,769$ \\
\hline Manganese & $\mathrm{Mn}$ & \\
\hline Mercury & $\mathrm{Hg}$ & $\begin{array}{l}132,133,395,593,594,595 \\
596,740,803\end{array}$ \\
\hline Molybdenum & Mo & \\
\hline Molybdenum hexacarbonyl & $\mathrm{Mo}(\mathrm{CO})_{6}$ & g566 \\
\hline Nickel & $\mathrm{Ni}$ & $193,420,442,443,480,593$ \\
\hline
\end{tabular}


Table 3. Inorganic Substances Included in EPA Lists of Hazardous Substances and/or Treated by a Photocatalytic Process

\begin{tabular}{|c|c|c|}
\hline Substance/Element & Formula/Symbol & Reference \\
\hline 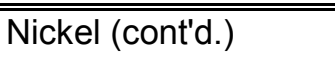 & $\mathrm{Ni}$ & $594,595,596$ \\
\hline Nitrates/nitrites & $\mathrm{NO}_{3}(-1), \mathrm{NO}_{2}(-1)$ & $\begin{array}{l}96,416,457,588,589,611 \\
612,654,852\end{array}$ \\
\hline Nitrogen oxides & $\mathrm{NO}_{x}, \mathrm{~N}_{2} \mathrm{O}$ & $\begin{array}{l}\mathrm{g} 26, \mathrm{~g} 27, \mathrm{~g} 30, \mathrm{~g} 31, \mathrm{~g} 32, \\
\mathrm{~g} 224, \mathrm{~g} 289, \mathrm{~g} 290, \mathrm{~g} 291, \\
\mathrm{~g} 292, \mathrm{~g} 293, \mathrm{~g} 312, \mathrm{~g} 313, \\
\mathrm{~g} 383, \mathrm{~g} 515, \mathrm{~g} 519, \mathrm{~g} 528, \\
\mathrm{~g} 534, \mathrm{~g} 727, \mathrm{~g} 747, \mathrm{~g} 783, \\
\mathrm{~g} 815, \mathrm{~g} 818,819, \mathrm{~g} 847\end{array}$ \\
\hline Nitrogen & $\mathrm{N}_{2}$ & \\
\hline Oxygen & $\mathrm{O}_{2}$ & \\
\hline Ozone & $\mathrm{O}_{3}$ & \\
\hline Palladium & $\mathrm{Pd}$ & \\
\hline Phosphorus & $P$ & \\
\hline Platinum & $\mathrm{Pt}$ & $\begin{array}{l}20,55,324,487,593,594 \\
595,596\end{array}$ \\
\hline Radium & $\mathrm{Ra}$ & \\
\hline Radon & $\mathrm{Rn}$ & \\
\hline Rhodium & Rh & \\
\hline Selenium & Se & \\
\hline Silicon & $\mathrm{Si}$ & \\
\hline Silver & $\mathrm{Ag}$ & $\begin{array}{l}426,438,473,513,562,593, \\
594,595,596,642,724\end{array}$ \\
\hline Strontium & $\mathrm{Sr}$ & \\
\hline Sulfate radical & $\mathrm{SO}_{4}(1-)$ & \\
\hline Sulfite & $\mathrm{SO}_{3}(1-)$ & 61 \\
\hline Sulfur & S & \\
\hline Sulfur oxides & $\mathrm{SO}_{\mathrm{x}}$ & $\mathrm{g} 26,187, \mathrm{~g} 224, \mathrm{~g} 747$ \\
\hline Sulfuric acid & $\mathrm{H}_{2} \mathrm{SO}_{4}$ & \\
\hline Thallium & $\mathrm{TI}$ & \\
\hline Thiocyanate & $\operatorname{SCN}(1-)$ & $55,58,60,148$ \\
\hline Thiosulfate & $\mathrm{S}_{2} \mathrm{O}_{3}(2-)$ & \\
\hline Thorium & Th & \\
\hline Tin & Sn & \\
\hline Tritium & $\mathrm{H},(\mathrm{T})$ & \\
\hline Tungsten & W & \\
\hline Vanadium & V & \\
\hline Zinc & $\mathrm{Zn}$ & \\
\hline
\end{tabular}




\subsection{Conclusions}

The level of activity in this field remains high. The potential to develop new technology for environmental remediation is still a driving force for the R\&D activity; however, applications such as indoor air purification, disinfection and cell killing, and self-cleaning surfaces have moved more quickly to commercialization. Clearly, many companies see potential markets for indoor air quality applications. In research more attention is being paid to detecting and identifying intermediates and by-products that can be formed during the photocatalytic process, both in aqueous and gas-phase systems. This is an impor- tant tool in developing an understanding of the chemical mechanisms of the processes and is necessary to ensure that potentially harmful substances are not left in the processed stream. Key areas of work identified in the last report continue to be important. Few studies include mass balances for the reactions, and kinetic models that can be used to size treatment systems are still rare. As systems are deployed in the field, it is increasingly important that the issues of catalyst lifetime and regeneration be addressed. Related to this is the need to identify those components of an air or water stream that can inhibit or kill activity. All these are important to the design of efficient and economical treatment systems. Questions concerning the economic viability of photocatalytic processes are being raised more often, and the significance of simple mineralization of one more organic compound without regard to the amount of energy or time that it took is questioned by those who want to see the process efficiency improved. This may be taken as a sign that the field is maturing. Entrepreneurs and companies would like to capitalize on the scientific foundation that has been developed for photocatalytic chemistry. 


\subsection{Bibliography}

\subsection{Published Material}

1. Abdel-Wahab, Aboel-Magd A., and Abd El-Aal M. Gaber. " $\mathrm{TiO}_{2}$-Photocatalytic Oxidation of Selected Heterocyclic Sulfur Compounds." J. Photochem. Photobiol. A 114(3) (1998): 213-218.

2. Abo, Toshio. "The Prediction of Service Life of Acrylic Emulsion Coatings." Techno-Cosmos 12 (1997): 57-62.

3. Aguera, A., uE. Almansa, S. Malato, M.I. Maldonado, and A.R. Fernandez-Alba. "Evaluation of Photocatalytic Degradation of Imidacloprid in Industrial Water by GC-MS and LC-MS." Analysis 26(7) (1998): 245-251.

4. Akikusa, Jun and Shahed U.M. Khan. "Stability of Nanocrystalline $\mathrm{N}-\mathrm{TiO}_{2}$ and $\mathrm{N}-\mathrm{TiO}_{2} / \mathrm{Mn}_{2} \mathrm{O}_{3}$ Films during Photoelectrolysis of Water." Proc. Electrochem. Soc. 97-11, Quantum Confinement: Nanoscale Materials, Devices, and Systems (1997): 65-78.

5. Alberici, Rosana M., Maria Anita Mendes, Wilson F. Jardim, and Marcos N. Eberlin. "Mass Spectrometry Online Monitoring and MS2 Product Characterization of $\mathrm{TiO}_{2} / \mathrm{UV}$ Photocatalytic Degradation of Chlorinated Volatile Organic Compounds.” J. Am. Soc. Mass Spectrom. 9(12) (1998): 1321-1327.

6. Alemany, Luis J., Miguel A. Banares, Encarnacion Pardo, Francisco Martin, Mercedes GalanFereres, and Jose M. Blasco. "Photodegradation of Phenol in Water Using Silica-Supported Titania Catalysts.” Appl. Catal. B 13(3-4) (1997): 289-97.

7. Alemany, Luis J., Miguel A. Banares, Encarnacion Pardo, Francisco Martin, Mercedes GalanFereres, and Jose M. Blasco. "Photodegradation of Phenol in Water Using Silica-Supported Titania Catalysts.” J. Adv. Oxid. Technol. 3(2) (1998): 155-161.

8. Alfano, O.M., R.J. Brandi, M.I. Cabrera, and A.E. Cassano. "Photocatalytic Reactions with a Suspension of Fine Solid Particles. A Precise Evaluation of the Absorbed Radiation Energy." Proc. Electrochem. Soc. 98-5, Environmental Issues in the Electronics/Semiconductor Indus- tries and Electrochemical/Photochemical Methods for Pollution Abatement (1998): 158-173.

9. Alfano, Orlando M., Maria I. Cabrera, and Alberto E. Cassano. "Photocatalytic Degradation of Chlorinated Hydrocarbons. A General Model Accounting for Radiation Energy Absorption Effects." Oxid. Technol. Water Wastewater Treat., Int. Conf., ed. Alfons Vogelpohl, Paper no. 44, ClausthalZellerfeld, Germany: Papierflieger Verlag (1996).

10. Alfano, Orlando M., Maria I. Cabrera, and Alberto E. Cassano. "Photocatalytic Reactions Involving Hydroxyl Radical Attack. I. Reaction Kinetics Formulation with Explicit Photon Absorption Effects.” J. Catal. 172(2) (1997): 370-379.

11. Aliskandarani, M., C. Dupuy-Maillard, M. Petit-Ramel, J.P. Percherancier, H. Brun, and B. Pouyet. "Optimum Irradiation Conditions for the Photocatalytic Degradation of Some Pollutants." Fresenius Environ. Bull. 5(9-10) (1996): 569-573. 
12. Allen, Norman S., Michele Edge, Teresa Corrales, and Fernando Catalina. "Stabilizer Interactions in the Thermal and Photooxidation of Titanium Dioxide Pigmented Polypropylene Films." Polym. Degrad. Stab. 61(1) (1998): 139-149.

13. Alpert, Daniel J., Jeremy L. Sprung, James E. Pacheco, Michael R. Prairie, Hugh E. Reilly, Thomas A. Milne, and Mark R. Nimlos. "Sandia National Laboratories' Work in Solar Detoxification of Hazardous Wastes.” Solar Energy Materials 24 (1991): 594-607.

14. Anderson, Carl and Allen J. Bard. "Improved Photocatalytic Activity and Characterization of Mixed $\mathrm{TiO}_{2} / \mathrm{SiO}_{2}$ and $\mathrm{TiO}_{2} / \mathrm{Al}_{2} \mathrm{O}_{3}$ Materials." J. Phys. Chem. B 101(14) (1997): 2611-2616.

15. Anderson, John V. and Richard J. Clyne. Solar Detoxification Technology: Using Energy from the Sun to Destroy Hazardous Waste, SERI/TP-250-4474. SERI, Golden, CO (1991). DE91015007.

16. Anderson, John V., Harold Link, Mark Bohn, and Bimleshwar Gupta. "Development of Solar Detoxification Technology in the USA - an Introduction.” Solar Energy Materials 24 (1991): $538-549$.

17. Anderson, Marc A., Walter Zeltner, Xianzhi Fu, and Dean Tompkins. "Chamber Studies Comparing the Effectiveness of Photocatalytic Degradation and Activated Carbon for the Treatment of Indoor Air." Proc. Annu. Meet. Air Waste Manage. Assoc., 89th (1996): fa14603/1-fa14603/10.

18. Anderson, Marc A., Walter A. Zeltner, Xianzhi Fu, Dean T. Tompkins, and Douglas T. Reindl. "Photocatalytic Degredation of Formaldehyde and Other VOCs in Indoor Air." CIAR Currents, December 1996, p. 1.

19. Ando, Hitoshi. “Titanium Dioxide for Cosmetics.” Fragrance J. 25(8) (1997): 65-73.

20. Angelidis, T.N., M. Koutlemani, and I. Poulios. "Kinetic Study of the Photocatalytic Recovery of Pt from Aqueous Solution by $\mathrm{TiO}_{2}$, in a Closed-Loop Reactor." Appl. Catal. B 16(4) (1998): $347-357$.

21. Annapragada, Rao, Robert Leet, Rajnish Changrani, and Gregory B. Raupp. "Vacuum Photocatalytic Oxidation of Trichloroethylene.” Environ. Sci. Technol. 31(7) (1997): 1898-1901.

22. Anon. "Air Contaminants.” ASHRAE Handbook - Applications 12.1-12.8ASHRAE, 1991.

23. Anon. Conceptual Design of a Photocatalytic Wastewater Treatment Plant, SAND91-7005. SNL, Albuquerque, NM (1991).

24. Anon. Development of a Homogeneous Aqueous Phase Photocatalyst for the Solar Detoxification of Water - Final Report of NREL Subcontract No. DE-AC02-83CH10093, Solarchem Environmental Systems, Markham, Ontario (1995).

25. Anon. Gas Phase Photocatalytic Oxidation Remediation and Process Pollution Market Study Final Report for NREL Subcontract Number AXE-6-16648-01, NEPCCO Environmental Systems (1997). 
26. Anon. "New Functional Paints by Titanium Dioxide Photocatalysts." Kogyo Toso 152 (1998): $74-77$.

27. Anpo, M. "In Situ Characterization of Highly Dispersed Catalysts Included within Zeolite Cavities and Their Photocatalytic Reactivities." Nuovo Cimento Soc. Ital. Fis. D 19D(1) (1997): 1641-1648.

28. Anpo, M. "Applications of $\mathrm{TiO}_{2}$ Photocatalysts to Better Our Environment: Approaches in Achieving Highly Efficient Reactions and Realizing the Use of Visible Light." BHR Group Conf. Ser. Publ. 30 (Protecting the Environment) (1998): 75-88.

29. Anpo, Masakazu, Yuichi Ichihashi, Masato Takeuchi, and Hiromi Yamashita. "Design of Unique Titanium Oxide Photocatalysts by an Advanced Metal Ion-Implantation Method and Photocatalytic Reactions under Visible Light Irradiation." Res. Chem. Intermed. 24(2) (1998): 143-149.

30. Anpo, Masakazu, Yuichi Ichihashi, Yuji Tamada, Hiromi Yamashita, Tomohiro Yoshinari, and Yasuo Suzuki. "The Utilization of Visible Light by Titanium Dioxide Photocatalysts Modified by a Metal Ion Implantation Method." Proc. Electrochem. Soc. 97-20, Photoelectrochemistry (1997): $331-334$.

31. Anpo, Masakazu, Yuichi Ichihashi, and Hiromi Yamashita. "Developments of Active Titanium Oxide Catalyst for Removal of NOx and Visible Light Sensitive Second Generation Titanium Oxide Photocatalyst." Petrotech 20(1) (1997): 66-72.

32. Anpo, Masakazu, Yuichi Ichihashi, and Hiromi Yamashita. " $\mathrm{TiO}_{2}$ Photocatalysts Able to Operate under Visible Light Irradiation - New Development by Ion-Implantation Method.” Optronics 186 (1997): 161-165.

33. Anpo, Masakazu, and Hiromi Yamashita. "Photochemistry of Surface Species Anchored on Solid Surfaces." Wiley Ser. Photosci. Photoeng. 1 (Surface Photochemistry) (1996): 117-164.

34. Anpo, Masakazu, Hiromi Yamashita, Yuichi Ichihashi, Yo Fujii, and Miwa Honda. "Photo- catalytic Reduction of $\mathrm{CO}_{2}$ with $\mathrm{H}_{2} \mathrm{O}$ on Titanium Oxides Anchored within Micropores of Zeolites: Effects of the Structure of the Active Sites and the Addition of Pt." J. Phys. Chem. B 101(14) (1997): 26322636.

35. Anpo, Masakazu, Hiromi Yamashita, Keita Ikeue, Yo Fujii, Yuichi Ichihashi, Shu Gou Zhang, Dal Ryung Park, Shaw Ehara, Sang-Eon Park, Jong-San Chang, and Jung Whan Yoo. "Photocatalytic Reduction of $\mathrm{CO}_{2}$ with $\mathrm{H}_{2} \mathrm{O}$ on Titanium Oxides Anchored within Zeolites." Stud. Surf. Sci. Catal. 114, Advances in Chemical Conversions for Mitigating Carbon Dioxide (1998): 177-182.

36. Anpo, Masakazu, Hiromi Yamashita, Keita Ikeue, Yo Fujii, Shu Guo Zhang, Yuichi Ichihashi, Dal Ryung Park, Yasuo Suzuki, Keiko Koyano, and Takashi Tatsumi. "Photocatalytic Reduction of $\mathrm{CO}_{2}$ with $\mathrm{H}_{2} \mathrm{O}$ on Ti-MCM-41 and Ti-MCM-48 Mesoporous Zeolite Catalysts." Catal. Today 44(1-4) (1998): 327-332.

37. Aoki, Akihiko and Gyoichi Nogami. "Fabrication of Anatase Thin Films from Peroxo-Polytitanic Acid by Spray Pyrolysis.” J. Electrochem. Soc. 143(9) (1996): L191-L192. 
38. Armon, R., N. Laot, N. Narkis, and I. Neeman. "Photocatalytic Inactivation of Different Bacteria and Bacteriophages in Drinking Water at Different $\mathrm{TiO}_{2}$ Concentration with or without Exposure to $\mathrm{O}_{2}$." J. Adv. Oxid. Technol. 3(2) (1998): 145-150.

39. Aronson, Blake J., Christopher F. Blanford, and Andreas Stein. "Solution-Phase Grafting of Titanium Dioxide onto the Pore Surface of Mesoporous Silicates: Synthesis and Structural Characterization." Chem. Mater. 9(12) (1997): 2842-2851.

40. Aruna, S.T. and K.C. Patil. "Synthesis and Properties of Nanosize Titania." J. Mater. Synth. Process. 4(3) (1996): 175-179.

41. Asano, Akihiko, Keisuke Okumoto, and Kei Kameoka. "Fixing of Titania Powder by an Arc Thermal Spraying and Photo-Oxidation Ability." Kenkyu Hokoku - Ehime-Ken Kogyo Gijutsu Senta 35 (1997): 45-50.

42. Assabbane, A., A. Boussaoud, A. Albourine, Y. Aitichou, and M. Petit-Ramel. "Photodegradation of Some Benzene Polycarboxylic Acids in the Presence of UV Irradiated Titanium Dioxide." Ann. Chim. 22(5) (1997): 301-311.

43. Assink, J.W. and J.M. Slaager. "Endurance Test of $\mathrm{TiO}_{2}$-Based Photocatalytic Oxidation." J. Adv. Oxid. Technol. 3(2) (1998): 138-144.

44. Atobe, Mahito, Yoshifumi Kado, and Tsutomu Nonaka. "Ultrasonic Effects on Electrocatalytic Processes.” Novel Trends Electroorg. Synth. [Pap. Int. Symp.], 3rd, ed. Sigeru Torii, Tokyo, Japan: Springer (1998): 253-254.

45. Augugliaro, Vincenzo, Vittorio Loddo, Giuseppe Marci, Leonardo Palmisano, and Maria Jose Lopez-Munoz. "Photocatalytic Oxidation of Cyanides in Aqueous Titanium Dioxide Suspensions." J. Catal. 166(2) (1997): 272-283.

46. Avila, P., A. Bahamonde, J. Blanco, B. Sanchez, A.I. Cardona, and M. Romero. "Gas-Phase PhotoAssisted Mineralization of Volatile Organic Compounds by Monolithic Titania Catalysts." Appl. Catal. B 17(1-2) (1998): 75-88.

47. Awatani, Tadashi, Kevin D. Dobson, A. James McQuillan, Bunsho Ohtani, and Kohei Uosaki. "In Situ Infrared Spectroscopic Studies of Adsorption of Lactic Acid and Related Compounds on the $\mathrm{TiO}_{2}$ and $\mathrm{CdS}$ Semiconductor Photocatalyst Surfaces from Aqueous Solutions." Chem. Lett. 8 (1998): 849-850.

48. Azumi, Kazuhisa. "Structure and Properties of Anodic Oxide Film on Titanium." Hyomen Gijutsu 49(1) (1998): 39-43.

49. Baciocchi, Enrico, Massimo Bietti, Marina I. Ferrero, Cesare Rol, and Giovanni V. Sebastiani. "Photo-Oxidative Fragmentation of Some -Alkyl Substituted 4-Methoxybenzyl Alcohols and Methyl Ethers Sensitized by $\mathrm{TiO}_{2}$." Acta Chem. Scand. 52(2) (1998): 160-164.

50. Baciocchi, Enrico, Tiziana Del Giacco, Marina I. Ferrero, Cesare Rol, and Giovanni V. Sebastiani. "Oxidation of Aromatic Sulfides Photosensitized by $\mathrm{TiO}_{2}$ in $\mathrm{CH}_{3} \mathrm{CN}$ in the Presence of $\mathrm{Ag}_{2} \mathrm{SO}_{4}$. The Role of $\mathrm{TiO}_{2}$ in the Chemistry of Sulfide Radical Cations." J. Org. Chem. 62(12) (1997): 40154017. 
51. Bacsa, R.R. and J. Kiwi. "Effect of Rutile Phase on the Photocatalytic Properties of Nanocrystalline Titania during the Degradation of p-Coumaric Acid.” Appl. Catal. B 16:1 (1998): 19-29.

52. Bahnemann, D., L. Bousselmi, H. Freudenhammer, A. Ghrabi, S.-U. Geissen, U. Siemon, F. Saleh, A. Si-Salah, and A. Vogelpohl. "Detoxification and Recycling of Wastewater by Solar-Catalytic Treatment." Oxid. Technol. Water Wastewater Treat., Int. Conf., ed. Alfons Vogelpohl, Paper no. 46, Clausthal-Zellerfeld, Germany: Papierflieger Verlag (1996).

53. Bahnemann, D., L. Bousselmi, H. Freudenhammer, A. Ghrabi, S.-U. Geissen, U. Siemon, F. Saleh, A. Si-Salah, and A. Vogelpohl. "Detoxification and Recycling of Wastewater by Solar-Catalytic Treatment." Oxid. Technol. Water Wastewater Treat., Int. Conf., ed. Alfons Vogelpohl, Paper no. 6, Clausthal-Zellerfeld, Germany: Papierflieger Verlag (1996).

54. Bahnemann, D., J. Cunningham, M.A. Fox, E. Pelizzetti, P. Pichat, and N. Serpone. "Photocatalytic Treatment of Waters." Aquat. Surf. Photochem., eds. George R. Helz, Richard G. Zepp, and Donald G. Crosby, Boca Raton, FL: Lewis (1994): 261-316.

55. Bahnemann, D., A. Henglein, J. Lilie, and L. Spanhel. "Flash Photolysis Observation of the Absorption Spectra of Trapped Positive Holes and Electrons in Colloidal Titanium Dioxide." J. Phys. Chem. 88(4) (1984): 709-711.

56. Bahnemann, Detlef. "Solar Detoxification of Wastewater." Nachr. Chem., Tech. Lab. 42(4) (1994): 378.

57. Bahnemann, Detlef. "Photocatalytic Detoxification of Polluted Waters." Environmental Photochemistry, vol. 2, ed. P. Boule, Berlin, Germany: Springer (1999): 285-351.

58. Bahnemann, Detlef, Arnim Henglein, and Lubomir Spanhel. "Detection of the Intermediates of Colloidal Titania-Catalyzed Photoreactions.” Faraday Discuss. Chem. Soc. 78 (1984): 151-163.

59. Bahnemann, Detlef W., Dirk Bockelmann, Roland Goslich, and Marcus Hilgendorff. "Photocatalytic Detoxification of Polluted Aquifers: Novel Catalysts and Solar Applications." Aquat. Surf. Photochem., eds. George R. Helz, Richard G. Zepp, and Donald G. Crosby, Boca Raton, FL: Lewis (1994): 349-367.

60. Bahnemann, Detlef W., Marcus Hilgendorff, and Ruediger Memming. "Charge Carrier Dynamics at $\mathrm{TiO}_{2}$ Particles: Reactivity of Free and Trapped Holes.” J. Phys. Chem. B 101(21) (1997): 42654275.

61. Bahnemann, Detlef W. and Michael R. Hoffmann. "Stabilization of Free Radical Intermediates on Metal Oxide Semiconductor Surfaces." Proc. Electrochem. Soc. 88(14) (1988): 74-80.

62. Balakrishnan, S. "Mitigation of Photo-Oxidation of Leather Pigments by Polymer Modification of Titanium Dioxide." Macromol.—New Front., Proc. IUPAC Int. Symp. Adv. Polym. Sci. Technol., ed. K.S.V. Srinivasan, New Delhi, India: Allied Publishers Ltd. (1998): 1126-1130.

63. Bekbolet, Miray. "Removal of Natural Organic Matter in Water by Heterogeneous Photocatalytic Oxidation Process." Oxid. Technol. Water Wastewater Treat., Int. Conf., ed. Alfons Vogelpohl, Paper no. 36, Clausthal-Zellerfield, Germany: Papierflieger Verlag (1996). 
64. Bekbolet, Miray. "Photocatalytic Bactericidal Activity of $\mathrm{TiO}_{2}$ in Aqueous Suspensions of E. coli." Wat. Sci. Technol. 35(11-12) (1997): 95-100.

65. Bekbolet, Miray and Claudia V. Araz. "Inactivation of E. coli by Photocatalytic Oxidation." Chemosphere 32(5) (1996): 959-965.

66. Bekbolet, Miray, Ferhan Cecen, and Gulhan Ozkosemen. "Photocatalytic Oxidation and Subsequent Adsorption Characteristics of Humic Acids." Water Sci. Technol. 34(9), Water Quality International '96, Part 5 (1996): 65-72.

67. Bekbolet, Miray and Nikola Getoff. "Photocatalytic Decomposition of Chlorinated Benzal- dehydes in Aqueous Solution Using $\mathrm{TiO}_{2}$." J. Adv. Oxid. Technol. 3(2) (1998): 162-166.

68. Bellmann, E., J. Lobedank, H. Ross, and J. Bendig. "Sensitized Photocatalytic Oxidation of S-Triazine Herbicides." J. Inf. Rec. 23(1-2), 14th Conference Photochemistry Section of the Society of German Chemists, 1995, Pt. 2 (1996): 43-45.

69. Bellobono, Ignazio Renato, Franco Gianturco, and Claudia Maria Chiodaroli. "Pilot-Plant Photomineralization of Volatile Organic Compounds in Air by Photocatalytic Membranes Immobilizing Titanium Dioxide and Promoting Photocatalysts." Fresenius Environ. Bull. 6(7-8) (1997): 469-474.

70. Bellobono, Ignazio Renato, Roberto Morelli, and Claudia Maria Chiodaroli. "Photocatalysis and Promoted Photocatalysis during Photocrosslinking of Multifunctional Acrylates in Composite Membranes Immobilizing Titanium Dioxide.” J. Photochem. Photobiol. A 105(1) (1997): 89-94.

71. Bellobono, Ignazio Renato, Paola Luciana Pinacci, Giancarlo Riva, and Claudio Lagrasta. "PilotPlant Photomineralization of S-Triazines in Aqueous Solution, by Photocatalytic Membranes Immobilizing Dioxide and Trialkyl Vanadates Photocatalysts." Fresenius Environ. Bull. 7(5-6) (1998): 277-288.

72. Benoit-Marquie, Florence, Edith Puech-Costes, Andre M. Braun, Esther Oliveros, and MarieTherese Maurette. "Photocatalytic Degradation of 2,4-Dihydroxybenzoic Acid in Water: Efficiency Optimization and Mechanistic Investigations." J. Photochem. Photobiol. A 108(1) (1997): 65-71.

73. Berry, C.W., T.J. Moore, J.A. Safar, and M.J. Wagner. "Antibacterial Activity of Dental Implant Metals." Implant Dent. (BPT) 1(1) (1992): 59-65.

74. Beydoun, D., R. Amal, G. Low, and S. McEvoy. "A Preliminary Investigation into the Synthesis of Titania Coated Magnetite as a Novel Photocatalyst." World Congr. Part. Technol. 3, Rugby, UK: Institution of Chemical Engineers (1998): 4083-4092.

75. Bignozzi, C.A., R. Argazzi, M.T. Indelli, F. Scandola, J.R. Schoonover, and G.J. Meyer. "Intercomponent and Interfacial Electron Transfer Processes in Polynuclear Metal Complexes Anchored on Transparent $\mathrm{TiO}_{2}$ Films." Proc. Indian Acad. Sci., Chem. Sci. 109(6) (1997): 397-409.

76. Biguzzi, Marina and G. Shama. "Effect of Titanium Dioxide Concentration on the Survival of Pseudomonas stutzeri during Irradiation with Near Ultraviolet Light." Letters in Applied Microbiology 19 (1994): 458-460. 
77. Blake, Daniel M., Lynnae Carlson-Boyd, and Gina Kissel. "Photochemical Pollution Control. The Final Report of the Solar Industrial Program Solar Detoxification Project." Golden, CO: The National Renewable Energy Laboratory (1998).

78. Blake, Daniel M., Kimberly Magrini-Bair, Edward Wolfrum, and E. Kenneth May. "Material Issues in Solar Detoxification of Air and Water." Optical Materials Technology for Energy Efficiency and Solar Energy Conversion XV, eds. Carl M. Lampert, Claus G. Granqvist, Michael Gratzel, and Satyen K. Deb, in Proceedings of SPIE, Bellingham, WA: SPIE-The International Society for Optical Engineering (1997): 154-162.

79. Blake, Daniel M., Pin-Ching Maness, Zheng Huang, Edward J. Wolfrum, Jie Huang, and William A. Jacoby. "Application of the Photocatalytic Chemistry of Titanium Dioxide to Disinfection and the Killing of Cancer Cells." Separation and Purification Methods 28(1) (1999): 1-50.

80. Blanco, J. and S. Malato. "Photocatalytic Treatment of Hazardous Waste Water; Cost Compar- ison between Solar and Electrical Technologies." Inter. Conf. on Comparative Assessments of Solar Power Technologies, eds. A. Roy and W. Grasse, Israel (1994) 217-230.

81. Blanco, J., S. Malato, D. Bahnemann, D. Bockelmann, D. Weichgrebe, F. Carmona, and F. Martinez. "Effective Industrial Wastewater Treatment by Solar Photocatalysis; Applications to Fine Chemicals Spanish Company." 7th Intern. Symp. on Solar Thermal Concentrating Technol., eds. O. Popel, S. Fris, and E. Shchedrova, Moscow, Russia: Institute for High Temperature of Russian Academy of Science (1994): 468-481.

82. Blanco, J., S. Malato, and C. Richter. "Aplicaciones Quemicas de la Radiacion Solar. Tecnologeas Mediambientales para Problemas Mediambientales." III Congreso Nacional de la Energea, Serena, Chile: Universidad de la Serena (1996): 177-182.

83. Blanco, J., S. Malato, and C. Richter. "Solar Photocatalytic Technology to the Treatment of Water Contaminants from Agriculture Activity in the Mediterranean Area." Proc. of Mediterranean Conf. on Renew. En. Sources for Wat. Prod. (1996): 147-152.

84. Blanco, Julian and Sixto Malato. Tecnologia de Fotocatalisis Solar - Utilizacion de la Radiacion Solar para el Tratamiento de Contaminantes Industriales. Almeria, Spain: Institio de Estudios Almerienses de la Diputacion de Almeria CIEMAT (1996).

85. Blazkova, A., I. Csolleova, and V. Brezova. "Effect of Light Sources on the Phenol Degradation Using Pt $/ \mathrm{TiO}_{2}$ Photocatalysts Immobilized on Glass Fibers." J. Photochem. Photobiol. A 113(3) (1998): 251-256.

86. Block, S.S., V.P. Seng, and D.W. Goswami. "Chemically Enhanced Sunlight for Killing Bacteria." J. Sol. Energy Eng. 119(1) (1997): 85-91.

87. Boarini, P., V. Carassiti, A. Maldotti, and R. Amadelli. "Photocatalytic Oxygenation of Cyclohexane on Titanium Dioxide Suspensions: Effect of the Solvent and of Oxygen." Langmuir 14(8) (1998): 2080-2085.

88. Boberic, Gordana, Oliver Bajt, Boris Sket, and Jadran Faganeli. "Photochemical Degradation of Butyl Acrylate in Different Aqueous Media." Chemosphere 37(1) (1998): 33-40.

89. Bockelmann, D., R. Goslich, and D. Bahnemann. "Preparation and Characterization of Novel Mixed Titanium/Iron Oxide Photocatalysts for the Detoxification of Polluted Aquifers." Sol. 
Therm. Energy Util., eds. Manfred Becker, Karl-Heinz Funken, and Gernot Schneider, Berlin, Germany: Springer (1992): 397-429.

90. Bockelmann, D., M. Lindner, and D. Bahnemann. "From Nano-Sized Particles to Commercial Products: The Search for Novel Photocatalysts.” NATO ASI Ser. 3(12) (1996): 675-689.

91. Bockelmann, D., D. Weichgrebe, R. Goslich, and D. Bahnemann. "Concentrating versus NonConcentrating Reactors for Solar Water Detoxification.” Sol. Energy Mater. Sol. Cells 38(1-4) (1995): 441-451.

92. Bojarska, E., K. Pawlicki, and B. Czochralska. "Photocatalytic Reduction of Nicotinamide Coenzymes in the Presence of Titanium Dioxide: The Influence of Aliphatic Amino Acids." J. Photochem. Photobiol. A 108(2-3) (1997): 207-213.

93. Bolduc, Lysane and William A. Anderson. "Enhancement of the Biodegradability of Model Wastewater Containing Recalcitrant or Inhibitory Chemical Compounds by Photocatalytic PreOxidation.” Biodegradation 8(4) (1997): 237-249.

94. Bolduc, Lysane and William A. Anderson. "Enhancement of the Biodegradability of Wastewater Containing Recalcitrant or Inhibitory Chemical Compounds by Photocatalytic Pre-Oxidation." Global Environ. Biotechnol., Proc. Int. Symp. Int. Soc. Environ. Biotechnol., 3rd, ed. Donald L. Wise, Neth.: Kluwer, Dordrecht (1997): 451-461.

95. Bonsen, E.-M., M. Klare, S. Schroeter, R. Stahl, H. Jacobs, and J.A.C. Broekaert. "Photocatalytic Decomposition of Ammonia Using $\mathrm{TiO}_{2}$ Photosemiconductors. Implementation and Optimization in Relation to Decomposition Rates and Products." Sol. Chem. Sol. Material-forsch., eds. Manfred Becker and Karl-Heinz Funken, Heidelberg, Germany: Mueller (1997): 170-184.

96. Bonsen, Eva-Maria, Stefan Schroeter, Herbert Jacobs, and Jose A.C. Broekaert. "Photocatalytic Degradation of Ammonia with $\mathrm{TiO}_{2}$ as Photocatalyst in the Laboratory and under the Use of Solar Radiation." Chemosphere 35(7) (1997): 1431-1445.

97. Borthen, James and David Leviten. "Making Solar Detoxification of Contaminated Groundwater a Reality." Solar Engineering 1992, eds. William Stine, Jan Kreider, and Koichi Watanabe, New York, NY: ASME (1992): 57-63.

98. Boyes, A.P., S. Raymahasay, A.T. Sulidis, and J.M. Winterbottom. "Oxidation of Aqueous Organic Pollutants in Industrial Waste Water by Heterogeneous Photocatalysis Using a Cocurrent Downflow Bubble Column Contactor (CDC)." Water Pollut. III: Modell., Meas. Predict., Int. Conf., 3rd, eds. L.C. Wrobel, and P. Latinopoulos, Southampton, UK: Computational Mechanics Publications (1995): 313-320.

99. Brandi, Rodolfo J., Orlando M. Alfano, and Alberto E. Cassano. “A Flat Plate Reactor for Photocatalytic Reactions. Evaluation of Radiation Absorption Using Titanium Dioxide Suspensions." Oxid. Technol. Water Wastewater Treat., Int. Conf., ed. Alfons Vogelpohl, paper no. 43, Clausthal-Zellerfield, Germany: Papierflieger Verlag (1996).

100. Brezova, V., A. Blazkova, L. Karpinsky, J. Groskova, B. Havlinova, V. Jorik, and M. Ceppan. "Phenol Decomposition Using $\mathrm{Mn}^{+} / \mathrm{TiO}_{2}$ Photocatalysts Supported by the Sol-Gel Technique on Glass Fibers." J. Photochem. Photobiol. A 109(2) (1997): 177-183. 
101. Brezova, V., A. Blazkova, I. Surina, and B. Havlinova. "Solvent Effect on the Photocatalytic Reduction of 4-Nitrophenol in Titanium Dioxide Suspensions." J. Photochem. Photobiol. A 107(1-3) (1997): 233-237.

102. Brinkley, David and Thomas Engel. "Active Site Density and Reactivity for the Photocatalytic Dehydrogenation of 2-Propanol on $\mathrm{TiO}_{2}$ (110)." Surf. Sci. 415(3) (1998): L1001-L1006.

103. Brinkley, David and Thomas Engel. "Photocatalytic Dehydrogenation of 2-Propanol on $\mathrm{TiO}_{2}(110)$." J. Phys. Chem. B 102(39) (1998): 7596-7605.

104. Brown, Gordon E., Jr., Victor E. Henrich, William H. Casey, David L. Clark, Carick Egglestron, Andrew Felmy, D. Wayne Goodman, Michael Grätzel, Gary Maciel, Maureen I. McCarthy, Kenneth H. Nealson, Dimitri A. Sverjensky, Michael F. Toney, and John M. Zachara. "Metal Oxide Surfaces and Their Interactions with Aqueous Solutions and Microbial Organisms." Chem. Rev. 99(1) (1999): $77-174$.

105. Burrows, Hugh D., Ludmila Ernestova, Terence J. Kemp, Yori I. Skurlatov, Anatol P. Purmal, and Alexander N. Yermakov. "Kinetics and Mechanism of Photodegradation of Chlorophenols." Prog. React. Kinet. 23(3) (1998): 145-207.

106. Butterfield, I.M., P.A. Christensen, T.P. Curtis, and J. Gunlazuardi. "Water Disinfection Using an Immobilized Titanium Dioxide Film in a Photochemical Reactor with Electric Field Enhancement." Water Res. 31(3) (1997): 675-77.

107. Byrne, J.A., B.R. Eggins, N.M.D. Brown, B. McKinney, and M. Rouse. "Immobilization of $\mathrm{TiO}_{2}$ Powder for the Treatment of Polluted Water." Appl. Catal. B 17(1-2) (1998): 25-36.

108. Byrne, J. Anthony and Brian R. Eggins. "Photoelectrochemistry of Oxalate on Particulate $\mathrm{TiO}_{2}$ Electrodes." J. Electroanal. Chem. 457(1-2) (1998): 61-72.

109. Cabrera, Maria I., Orlando M. Alfano, and Alberto E. Cassano. "Absorption and Scattering Coefficients of Titanium Dioxide Particulate Suspensions in Water.” J. Phys. Chem.100(51) (1996): 20043-20050.

110. Cabrera, Maria I., Orlando M. Alfano, and Alberto E. Cassano. "Parameters for Photocatalytic Reactor Design. Absorption and Scattering Coefficients of Titanium Dioxide Suspensions." Oxid. Technol. Water Wastewater Treat., Int. Conf., ed. Alfons Vogelpohl, Paper no. 37, ClausthalZellerfield, Germany: Papierflieger Verlag (1996).

111. Cabrera, Maria I., Antonio C. Negro, Orlando M. Alfano, and Alberto E. Cassano. "Photocatalytic Reactions Involving Hydroxyl Radical Attack. II. Kinetics of the Decomposition of Trichloroethylene Using Titanium Dioxide.” J. Catal.172(2) (1997): 380-390.

112. Cai, Ruxiong, Kazuhito Hashimoto, Kiminori Itoh, and Akira Fujishima. "Photokilling of Malignant Cells with Ultrafine $\mathrm{TiO}_{2}$ Powder.” Bull. Chem. Soc. Jpn. 64(4) (1991): 1268-1273.

113. Cai, Ruxiong, Kazuhito Hashimoto, Yoshinobu Kubota, and Akira Fujishima. "Increment of Photocatalytic Killing of Cancer Cells Using $\mathrm{TiO}_{2}$ with the Aid of Superoxide Dismutase." Chem. Let. (1992): 427-430.

114. Cai, Ruxiong, Kiminori Itoh, Akira Fujushima, and Yoshinobu Kubota. "Photocatalytic Effect on Tumor Cells." Photomedicine and Photobiology 10 (1988): 253-255. 
115. Cai, Ruxiong, Yoshinobu Kubota, Taro Shuin, Hideki Sakai, Kazuhito Hashimoto, and Akira Fujishima. "Induction of Cytotoxicity by Photoexcited $\mathrm{TiO}_{2}$ Particles." Cancer Research 52 (1992): $2346-2348$.

116. Calza, Paola, Claudio Minero, and Ezio Pelizzetti. "Photocatalytically Assisted Hydrolysis of Chlorinated Methanes under Anaerobic Conditions." Environ. Sci. Technol. 31(8) (1997): 21982203.

117. Cao, Y.A., X.T. Zhang, L.Q. Chong, D.Y. Wang, T.F. Xie, Y. Huang, Z.F. Cui, W.G. Shi, X.J. Liu, Z.Y. Wu, Y.B. Bai, T.J. Li, and Y. Wu. "A Novel $\mathrm{TiO}_{2}$ Film Catalyst - Preparation, Properties and Research on Its Photocatalytic Activity." Mater. Res. Soc. Symp. Proc. 497, Recent Advances in Catalytic Materials (1998): 79-84.

118. Carey, J.H. "An Introduction to Advanced Oxidation Processes (AOP) for Destruction of Organics in Wastewater." Proc. Symp. Adv. Oxid. Processes Treat. Contam. Water Air, Paper no. 1, Burlington, Ont. Wastewater Technol. Cent. (1990).

119. Carey, John H., John Lawrence, and Helle M. Tosine. "Photodechlorination of PCB's in the Presence of Titanium Dioxide in Aqueous Suspensions.” Bull. Environ. Contam. Toxicol. 16(6) (1976): 697-701.

120. Carey, John H. and Barry G. Oliver. "The Photochemical Treatment of Waste Water by Ultraviolet Irradiation of Semiconductors." Water Pollut. Res. J. Can. 15(2) (1980): 157-185.

121. Cermenati, Laura, Mariella Mella, and Angelo Albini. "Titanium Dioxide Photocatalyzed Alkylation of Maleic Acid Derivatives.” Tetrahedron 54(11) (1998): 2575-2582.

122. Cermenati, Laura, Pierre Pichat, Chantal Guillard, and Angelo Albini. "Probing the $\mathrm{TiO}_{2}$ Photocatalytic Mechanisms in Water Purification by Use of Quinoline, Photo-Fenton Generated OH Radicals and Superoxide Dismutase.” J. Phys. Chem. B 101(14) (1997): 2650-2658.

123. Cermenati, Laura, Christoph Richter, and Angelo Albini. "Solar Light Induced Carbon-Carbon Bond Formation via $\mathrm{TiO}_{2}$ Photocatalysis." Chem. Commun. 7 (1998): 805-806.

124. Cerrillos, Consuelo and David F. Ollis. "Photocatalytic Reduction and Removal of Uranium from a Uranium-EDTA Solution." J. Adv. Oxid. Technol. 3(2) (1998): 167-173.

125. Chambers, S.A., Y. Gao, S. Thevuthasan, S. Wen, K.L. Merkle, N. Shivaparan, and R.J. Smith. "Strain, Structure and Electronic States in MBE Grown (Nb,Ti)O $\mathrm{O}_{2}$ Mixed Rutile." Mater. Res. Soc. Symp. Proc. 436, Thin Films: Stresses and Mechanical Properties VI (1997): 475-485.

126. Chapman, Timothy E., Philip H. Mook, Jr., and Kevin B. Wong. "A Comparison of Innovative Air Pollution Control Technology Demonstrations at McClellan Air Force Base." Proc. Annu. Meet. Air Waste Mgmt. Assoc. 90th (1997): MP504/1-MP504/15.

127. Chaudhuri, Ratan K. and George Majewski. "Amphiphilic Microfine Titanium Dioxide: Its Properties and Application in Sunscreen Formulations.” DCI 162(5) (1998): 24,26,28,30-31,99.

128. Chen, Dingwang and Ajay K. Ray. "Photodegradation Kinetics of 4-Nitrophenol in $\mathrm{TiO}_{2}$ Suspension." Water Res. 32(11) (1998): 3223-3234. 
129. Chen, Guoqing and Farhang Shadman. "Removal of Trace Surfactant from Ultrapure Water though UV Photolysis and Photocatalytic Oxidation." Semicond. Pure Water Chem. Conf., UPW \& Chemical Proceedings 15 (1996): 111-124.

130. Chen, Jie. Heterogeneous Photocatalysis: Photo-Assisted Oxidation of Isopropanol to Acetone and Photodegradation of Volatile Organic Compounds (Amorphous Manganese Oxide, Titanium Oxide, Trichloroethylene, Toluene, Triethylamine). Ph.D. diss., Univ. of Connecticut (1997).

131. Chen, L.X., M.R. Wasielewski, T. Rajh, P.L. Lee, M.C. Thurnauer, and P.A. Montano. "Molecular Structure Determination for Photogenerated Intermediates in Photoinduced Electron Transfer Reactions Using Steady-State and Transient XAFS.” J. Phys. IV 7:C2, X-Ray Absorption Fine Structure, vol. 1 (1997): 569-572.

132. Chen, Lin X., Tijana Rajh, Olga Micic, Zhiyu Wang, David M. Tiede, and Marion Thurnauer. "Photocatalytic Reduction of Heavy Metal Ions on Derivatized Titanium Dioxide Nano-Particle Surface Studied by XAFS.” Nucl. Instrum. Methods Phys. Res., Sect. B 133(1-4) (1997): 8-14.

133. Chen, Lin X., Tijana Rajh, Zhiyu Wang, and Marion C. Thurnauer. "XAFS Studies of Surface Structures of $\mathrm{TiO}_{2}$ Nanoparticles and Photocatalytic Reduction of Metal Ions." J. Phys. Chem. B 101(50) (1997): 10688-10697.

134. Chen, Shi-Fu and Xue-Li Cheng. "Photocatalytic Decomposition of Oil Films Floating on Water Using $\mathrm{TiO}_{2}$ Supported on Hollow Glass Microbeads by Sunlight." Chin. J. Chem. 16(5) (1998): $421-424$.

135. Chen, Shifu, Xin Liang, Jianhong Zhao, Liucheng Wang, and Mengyue Zhao. "Photocatalytic Degradation of Dichlorvos Using Titanium Dioxide Supported on Hollow Glass Microbeads." J. Environ. Sci. 9(3) (1997): 278-282.

136. Chen, Shifu, Mengyue Zhao, and Yaowu Tao. "Feasibility Study on Degradation of Organic Phosphorous Pesticide Wastewater by Photocatalysis." Huanjing Gongcheng 14(3) (1996): 10-13.

137. Chen, Shifu, Mengyue Zhao, and Yaowu Tao. "Photocatalytic Degradation of Organo- phosphorous Pesticides Using $\mathrm{TiO}_{2}$ Thin Film." Cuihua Xuebao 17(5) (1996): 455-458.

138. Chen, Shifu, Mengyue Zhao, Yaowu Tao, and Xin Liang. "Photocatalytic Degradation of Organophosphorus Pesticides Using $\mathrm{TiO}_{2}$ Supported on Fiberglass." Huanjing Kexue 17(4) (1996): $33-35$.

139. Chen, Xiang, Jialin Xu, and Tieyuan Zhang. "Experimental Research on Photocatalytic Degradation of Several Types of Chlorohydrocarbon.” Beijing Shifan Daxue Xuebao, Ziran Kexueban 33(2) (1997): 270-274.

140. Cheng, Cangcang and Dewen Hu. "Application of Fixed Bed Reactor to Photodegradation of Soluble Dye 4BS (Red) with Solar Light.” Huanjing Wuran Yu Fangzhi 20(4) (1998): 17-19.

141. Cheung, Samuel T.C., Annie K.M. Fung, and Michael H.W. Lam. "Visible Photosensitization of $\mathrm{TiO}_{2}$-Photodegradation of $\mathrm{CCl}_{4}$ in Aqueous Medium." Chemosphere 36(11) (1998): 2461-2473.

142. Chhazed, Meenu and Neeta P. Thacker. "UV Irradiations of OCIPs Using $\mathrm{TiO}_{2} / \mathrm{ZnO}$ in Aquatic System.” Indian J. Environ. Health 39(3) (1997): 222-229. 
143. Cho, I.H., J.H. Kwak, R. Ryoo, W.S. Ahn, K.Y. Jung, and S.B. Park. "Photocatalytic Decomposition of Trichloroethylene over Aluminosilicate Zeolites with Isomorphous Incorporation of Titanium." Stud. Surf. Sci. Catal. 105B, Progress in Zeolite and Microporous Materials, Pt. B (1997): 16171623.

144. Choi, J.H., D.H. Shin, K.P. Jang, K.C. Mangung, J.K. Kim, and W.J. Lee. "A Study on the Photocatalytic Properties of Sputtered $\mathrm{TiO}_{2}$ Films.” Taehan Kumsok Hakhoechi 36(9) (1998): 14771483 .

145. Choi, Wonyong. Photooxidative and Photoreductive Degradation of Chlorinated Hydrocarbons on Aqueous Titanium Dioxide Colloids. Ph.D. diss., California Inst. Technology (1996).

146. Choi, Wonyong and Michael R. Hoffmann. "Novel Photocatalytic Mechanisms for $\mathrm{CHCl}_{3}, \mathrm{CHBr}_{3}$, and $\mathrm{CCl}_{3} \mathrm{CO}_{2}^{-}$Degradation and the Fate of Photogenerated Trihalomethyl Radicals on $\mathrm{TiO}_{2}$." Environ. Sci. Technol. 31(1) (1997): 89-95.

147. Clarke, Jill, Roger R. Hill, and David R. Roberts. "Primary Processes in the Catalytic Photooxidation of P-Cresol." J. Chem. Technol. Biotechnol. 68(4) (1997): 397-404.

148. Colombo, D. Philip, Jr. and Robert M. Bowman. "Does Interfacial Charge Transfer Compete with Charge Carrier Recombination? A Femtosecond Diffuse Reflectance Investigation of $\mathrm{TiO}_{2}$ Nanoparticles." J. Phys. Chem. 100(47) (1996): 18445-18449.

149. Cooper, Adrienne T., D. Yogi Goswami, and Seymour S. Block. "Solar Photochemical Detoxification and Disinfection for Water Treatment in Tropical Developing Countries." $J$. Adv. Oxid. Technol. 3(2) (1998): 151-154.

150. Crittenden, John C., Junbiao Liu, David W. Hand, and David L. Perram. "Photocatalytic Oxidation of Chlorinated Hydrocarbons in Water." Water Res. 31(3) (1997): 429-438.

151. Crittenden, John, C. Rominder, P.S. Suri, David L. Perram, and David W. Hand. "Decontamination of Water Using Adsorption and Photocatalysis." Water Res. 31(3) (1997): 411-418.

152. Cui, Zhenfeng and Yongzhi Wang. "Photodegradation of Dibenzylsulfone Catalyzed by $\mathrm{TiO}_{2}$ Particles under UV Irradiation.” Jilin Daxue Ziran Kexue Xuebao 1 (1998): 100-102.

153. Curco, D., S. Malato, J. Blanco, and J. Gimenez. "Photocatalysis and Radiation Absorption in a Solar Plant." Solar Energy Materials and Solar Cells 4(4) (1996): 199-217.

154. D'Hennezel, Olga and David F. Ollis. "Trichloroethylene-Promoted Photocatalytic Oxidation of Air Contaminants.” J. Catal. 167(1) (1997): 118-126.

155. D’Hennezel, Olga Beatrice Therese Marie. Chlorine-Enhanced Gas-Solid Photocatalysis: Trichloroethylene Promotion, $\mathrm{TiO}_{2}$ Pre-Chlorination, Mechanistic Correlations, Intermediates Identification. Ph.D. diss., North Carolina State Univ. (1998).

156. Dai, Qing, Nongyue He, Yan Guo, and Chunwei Yuan. "High Photocatalytic Activity of Pure $\mathrm{TiO}_{2}$ Mesoporous Molecular Sieves for the Degradation of 2,4,6-Trichlorophenol." Chem. Lett. 11 (1998): $1113-1114$. 
157. Dai, Xiaming, Yonghua Chen, Qingfeng Li, Jialong Wang, and Hong Liu. "A Study on Photocatalytic Reduction of Cr(VI) in Aqueous Solution Using Ultrafine Powders of Semiconductor Oxides." Huanjing Kexue, 17(6) (1996): 34-36.

158. Datye, A.K., S. Srinivasan, L.F. Allard, C.H.F. Peden, J.R. Brenner, and L.T. Thompson. "Oxide Supported $\mathrm{MoS}_{2}$ Catalysts of Unusual Morphology.” J. Catal. 158(1) (1996): 205-216.

159. De Felip, E., F. Ferri, C. Lupi, N.M. Trieff, F. Volpi, and A. di Domenico. "Structure-Dependent Photocatalytic Degradation of Polychlorobiphenyls in a $\mathrm{TiO}_{2}$ Aqueous System." Chemosphere 33(11) (1996): 2263-2271.

160. De Tacconi, Norma R., Hongjian Wenren, Darrell McChesney, and Krishnan Rajeshwar. "Photoelectrochemical Oxidation of Formate Ions on Nickel-Titanium Dioxide Nanocomposite Electrodes: Unusually High 'Current Doubling' Yields and Manifestation of a Site Proximity Effect.” Langmuir 14(11) (1998): 2933-2935.

161. Diebold, Ulrike and T.E. Madey. "TiO 2 by XPS.” Surf. Sci. Spectra 1996 4(3) (1998): 227-231.

162. Dillert, R., M. Nahen, G. Fels, and D. Bahnemann. "Photocatalytic Treatment of TNT-Polluted Water." Oxid. Technol. Water Wastewater Treat., Int. Conf., ed. Alfons Vogelpohl, Paper no. 40, Clausthal-Zellerfeld, Germany: Papierflieger Verlag (1996).

163. Dillert, R., S. Vollmer, E. Gross, M. Schober, H.-J. Arntz, K. Pahlmann, J. Wienefeld, T. Schmedding, G. Sager, and D. Bahnemann. "Solar-Catalytic Treatment of an Industrial Wastewater." IPS-12 - Twelfth International Conference on Photochemical Conversion and Storage of Solar Energy (1998).

164. Dillert, Ralf and Detlef Bahnemann. "Photocatalytic Degradation of Organic Pollutants: Mechanisms and Solar Applications." EPA Newsl. 52 (1994): 33-52.

165. Dillert, Ralf and Detlef Bahnemann. "Photocatalytic Water Treatment: Chances and Limitations." Oxid. Technol. Water Wastewater Treat., Int. Conf., ed. Alfons Vogelpohl, Paper no. 5, ClausthalZellerfeld, Germany: Papierflieger Verlag (1996).

166. Dillert, Ralf, Iris Fornefett, Ulrike Siebers, and Detlef Bahnemann. "Photocatalytic Degradation of Trinitrotoluene and Trinitrobenzene: Influence of Hydrogen Peroxide." J. Photochem. Photobiol. A 94(2-3) (1996): 231-236.

167. Dillert, Ralf, Ulrich Siemon, and Detlef Bahnemann. "Photocatalytic Disinfection of Municipal Sewage.” Chem.-Ing.-Tech. 70(3) (1998): 308-310.

168. Dillert, Ralf, Ulrich Siemon, and Detlef Bahnemann. "Photocatalytic Disinfection of Municipal Wastewater." Chem. Eng. Technol. 21(4) (1998): 356-358.

169. Dominguez, C., J. Garcia, M.A. Pedraz, A. Torres, and M.A. Galan. "Photocatalytic Oxidation of Organic Pollutants in Water." Catal. Today 40(1) (1998): 85-101.

170. Dona-Rodriquez, J.M., C. Valdez do Campo, J.A. Herrera-Melian, E. Tello-Rendon, A. VieraSuarez, P. Bernardez-Cordero, J. Xaus, and J. Perez-Pena. "Photocatalytic Water Detoxification: Conditions Optimization and Pilot Plant Development." IPS-12 - Twelfth International Conference on Photochemical Conversion and Storage of Solar Energy (1998). 
171. Donaldson, K., P.H. Beswick, and P.S. Gilmour. "Free Radical Activity Associated with the Surface of Particles: A Unifying Factor in Determining Biological Activity?" Toxicology Letters 88(1-3) (1996): 293-298.

172. Dreyer, M., G.K. Newman, L. Lobban, S.J. Kersey, R. Wang, and J.H. Harwell. "Enhanced Oxidation of Air Contaminants on an Ultra-Low Density UV-Accessible Aerogel Photocatalyst." Mater. Res. Soc. Symp. Proc. 454, Advanced Catalytic Materials--1996 (1997): 141-146.

173. Driessen, M.D., A.L. Goodman, T.M. Miller, G.A. Zaharias, and V.H. Grassian. "Gas-Phase Photooxidation of Trichloroethylene on $\mathrm{TiO}_{2}$ and $\mathrm{ZnO}$ : Influence of Trichloroethylene Pressure, Oxygen Pressure, and the Photocatalyst Surface on the Product Distribution." J. Phys. Chem. B 102(3) (1998): 549-556.

174. Driessen, M.D. and V.H. Grassian. "Photooxidation of Trichloroethylene on $\mathrm{Pt} / \mathrm{TiO}_{2}$." J. Phys. Chem. B 102(8) (1998): 1418-1423.

175. Driller, Hansjurgen and Thekla Kurz. "Titanium Dioxide of the New Generation." Parfuem. Kosmet. 78(9) (1997): 8,10-11,13.

176. Dumitriu, D., A.R. Bally, C. Ballif, V.I. Parvulescu, P.E. Schmid, R. Sanjines, and F. Levy. "Reactive Sputtering as a Tool for Preparing Photocatalysts." Stud. Surf. Sci. Catal. 118, Preparation of Catalysts VII (1998): 485-493.

177. Dunford, R., A. Salinaro, L. Cai, N. Sepone, S. Horikoshi, H. Hidaka, and J. Knowland. "Chemical Oxidation and DNA Damage Catalysed by Inorganic Sunscreen Ingredients." FEBS Letters 418(1-2) (1997): 87-90.

178. Eggins, Brian R., Fiona L. Palmer, and J. Anthony Byrne. "Photocatalytic Treatment of Humic Substances in Drinking Water." Water Res. 31(5) (1997): 1223-1226.

179. Elder, S.H., Y. Gao, X. Li, J. Liu, D.E. McCready, and Windisch, Jr. "Zirconia-Stabilized 25-Å $\mathrm{TiO}_{2}$ Anatase Crystallites in a Mesoporous Structure." Chemistry of Materials 10(10) (1998): 31445.

180. Eliet, Veronique and Giovanni Bidoglio. "Kinetics of the Laser-Induced Photoreduction of U(VI) in Aqueous Suspensions of $\mathrm{TiO}_{2}$ Particles." Environ. Sci. Technol. 32(20) (1998): 3155-3161.

181. Enea, O., B. Zaytouni, and J. Moser. "Morphological and Photoelectrochemical Properties of Porous, Superimposed Au/TiO 2 Layers.” J. Appl. Electrochem. 28(1) (1998): 36-40.

182. Esgueva, E., J. Garcia, X. Domfenech, and J. Peral. "Photocatalyzed Destruction of Thiourea over $\mathrm{TiO}_{2}$ Powder." Oxid. Commun.20(4) (1997): 546-551.

183. Falaras, Polycarpos. "Synergetic Effect of Carboxylic Acid Functional Groups and Fractal Surface Characteristics for Efficient Dye Sensitization of Titanium Oxide.” Sol. Energy Mater. Sol. Cells 53(1-2) (1998): 163-175.

184. Falconer, John L. and Kimberley A. Magrini-Bair. "Photocatalytic and Thermal Catalytic Oxidation of Acetaldehyde on $\mathrm{Pt} / \mathrm{TiO}_{2}$. . J. Catal. 179(1) (1998): 171-178. 
185. Fang, Youlin, Wenkuan Zhao, Shaohua Yun, Qinhua Dong, and Yubin Shun. "Immobilization of Nanometer-Sized $\mathrm{TiO}_{2}$ on Hollow Ceramic Microbeads and Photocatalytic Decomposition of Octane." Yingyong Huaxue 14(2) (1997): 81-83.

186. Fang, Youling, Wenkuan Zhao, Guohua Zhang, and Qinhua Dong. "Photocatalytic Decompo- sition of Octane Using $\mathrm{TiO}_{2}$ Film Coatings on the Floating Glass Bead Surface Prepared by the DipCoating Technique." Huanjing Huaxue 16(5) (1997): 413-417.

187. Faust, Bruce C., Michael R. Hoffmann, and Detlef W. Bahnemann. "Photocatalytic Oxidation of Sulfur Dioxide in Aqueous Suspensions of -Iron Oxide $\left(\mathrm{Fe}_{2} \mathrm{O}_{3}\right)$." J. Phys. Chem. 93(17) (1989): 6371-6381.

188. Feitz, Andrew J., T. David Waite, Gary J. Jones, Brace H. Boyden, and Philip T. Orr. "Photocatalytic Degradation of the Blue Green Algal Toxin Microcystin-LR in a Natural Organic-Aqueous Matrix.” Environ. Sci. Technol. 33(2) (1999): 243-249.

189. Fernandez-Nieves, A., C. Richter, and F.J. de las Nieves. "Point of Zero Charge (PZC) Estimation for a $\mathrm{TiO}_{2}$ /Water Interface." Prog. Colloid Polym. Sci. 110 (1998): 21-24.

190. Ferry, John L. The Reduction of Nitrated Organics over Illuminated Suspensions of Titanium Dioxide. Ph.D. diss., Univ. of North Carolina at Chapel Hill (1996).

191. Ferry, John L. and William H. Glaze. "Photocatalytic Reduction of Nitro Organics over Illumi- nated Titanium Dioxide: Electron Transfer between Excited-State $\mathrm{TiO}_{2}$ and Nitroaromatics." J. Phys. Chem. B 102(12) (1998): 2239-2244.

192. Ferry, John L. and William H. Glaze. "Photocatalytic Reduction of Nitro Organics over Illumi- nated Titanium Dioxide: Role of the $\mathrm{TiO}_{2}$ Surface." Langmuir 14(13) (1998): 3551-3555.

193. Forouzan, Fardad, Thomas C. Richards, and Allen J. Bard. "Photoinduced Reaction at $\mathrm{TiO}_{2}$ Particles. Photodeposition from Ni(II) Solutions with Oxalate." J. Phys. Chem. 100(46) (1996): 18123-18127.

194. Foster, A.L., G.E. Brown, Jr., and G.A. Parks. "X-Ray Absorption Fine-Structure Spectroscopy Study of Photocatalyzed, Heterogeneous As(III) Oxidation on Kaolin and Anatase." Environ. Sci. Technol. 32(10) (1998): 1444-1452.

195. Foster, Nancy S., Carl A. Koval, Jeffrey G. Sczechowski, and Richard D. Noble. "Investigation of Controlled Periodic Illumination Effects on Photo-Oxidation Processes at Titanium Dioxide Films Using Rotating Ring-Disk Photoelectrochemistry.” J. Electroanal. Chem. 406(1-2) (1996): 213217.

196. Foster, Panayotis, I. Denis, and V. Jacob. “Aerosol Surface Reactions and Photocatalysis. Determination of .Beta.-Pinene OH Radical Rate Constant: Possible Impact of Solid Particles." Transp. Chem. Transform. Pollut. Troposphere (1996), Volume 2, Issue Heterogeneous and Liquid Phase Processes, ed. Peter Warneck, Transp. Chem. Transform. Pollut. Troposphere (1996), Berlin, Germany: Springer (1996): 191-196.

197. Fotou, George P. and Sotiris E. Pratsinis. "Photocatalytic Destruction of Phenol and Salicylic Acid with Aerosol-Made and Commercial Titania Powders." Chem. Eng. Commun. 151 (1996): 251-269.

198. Franco-Garcia, M.L., M. Murat, J.P. Percherancier, and B. Pouyet. "Investigation of Aqueous 
Adsorption-Desorption of Pesticides on Silica Gel in Photocatalysis by Silica-Supported Titanium Dioxide." Fresenius Environ. Bull. 5(9-10) (1996): 563-568.

199. Freudenhammer, H., D. Bahnemann, L. Bousselmi, S.-U. Geissen, A. Ghrabi, F. Saleh, A. Si-Salah, U. Siemon, and A. Vogelpohl. "Detoxification and Recycling of Wastewater by Solar-Catalytic Treatment." Water Sci. Technol. 35(4), Oxidation Technologies for Water and Wastewater Treatment (1997): 149-156.

200. Friesen, Duane A., David B. Gibson, and Cooper H. Langford. "Heterogeneous $\mathrm{Cs}_{3} \mathrm{PW}_{12} \mathrm{O}_{40}$ Photocatalysts." Chem. Commun. 5 (1998): 543-544.

201. Fu, Hongxiang, Gongxuan Lu, and Shuben Li. "Photocatalytic Reduction of Cr(VI) Ion in the Presence of Organics in Water Solutions.” Wuli Huaxue Xuebao 13(2) (1997): 106-112.

202. Fu, Hongxiang, Gongxuan $\mathrm{Lu}$, and Shuben Li. "Adsorption and Photo-Induced Reduction of $\mathrm{Cr}(\mathrm{VI})$ Ion in $\mathrm{Cr}(\mathrm{VI})-4 \mathrm{CP}$ (4-Chlorophenol) Aqueous System in the Presence of $\mathrm{TiO}_{2}$ as Photocatalyst." $J$. Photochem. Photobiol. A 114(1) (1998): 81-88.

203. $\mathrm{Fu}$, Hongxiang, Gongxuan $\mathrm{Lu}$, and Shuben $\mathrm{Li}$. "Adsorption of Chromium(VI) Ions on to $\mathrm{TiO}_{2}$ from Aqueous Solution.” Adsorpt. Sci. Technol. 16(2) (1998): 117-126.

204. Fu, Hongxiang, Gongxuan Lu, and Shuben Li. "Photo-Induced and Photocatalytic Reactions in Cr(VI)-Chlorophenol Systems.” Ganguang Kexue Yu Guang Huaxue 16(3) (1998): 237-244.

205. Fu, Hongxiang, Gongxuan Lu, Hong Zhang, and Shuben Li. "Adsorption and Photocatalytic Detoxification of $\mathrm{Cr}(\mathrm{VI})$ Ion on $\mathrm{TiO}_{2}$." Huanjing Kexue 19(3) (1998): 80-83.

206. Fu, Xianzhi, Louis A. Clark, Walter A. Zeltner, and Marc A. Anderson. "Effects of Reaction Temperature and Water Vapor Content on the Heterogeneous Photocatalytic Oxidation of Ethylene." J. Photochem. Photobiol. A 97(3) (1996): 181-186.

207. Fu, Xiao-Rong, Xiao-Gang Zhang, Shi-Geng Song, Guang-Ming Wu, Ming-De Tao, and Cheng-Lu Lin. "Influence of Annealing Atmosphere on the Structures and Photocatalytic Properties of AgDoped $\mathrm{TiO}_{2}$ Thin Film. Huaxue Xuebao 56(6) (1998): 521-526.

208. Fu, Xiaorong, Shigeng Song, Xueyan Wang, Hui Tan, Guangming Wu, and Mingde Tao. "Preparation of Nano-Sized $\mathrm{TiO}_{2} / \mathrm{Si}$ Thin Films and Their Photocatalytic Properties." Ganguang Kexue Yu Guang Huaxue 15(3) (1997): 234-240.

209. Fu, Xiaorong, Xiaogang Zhang, Shigeng Song, Xueyan Wang, Hui Tan, and Mingde Tao. "Preparation of Nano-Sized $\mathrm{TiO}_{2} / \mathrm{Pt} / \mathrm{Glass}$ Thin Films by Sol-Gel Method and Their Use in Photoelectric Degradation of Soluble Dyes." Yingyong Huaxue 14(4) (1997): 77-79.

210. Fu, Xiaorong, Xiaogang Zhang, Shigeng Song, Xueyan Wang, and Mingde Tao. "Preparation of Nano-Sized $\mathrm{TiO}_{2} / \mathrm{Pt} /$ Glass Thin Films by Sol-Gel Process and Their Photoelectro Catalytic Properties." Gongneng Cailiao 28(4) (1997): 411-414.

211. Fujii, Hiroyuki, Michitaka Ohtaki, and Koichi Eguchi. "Synthesis and Photocatalytic Activity of Lamellar Titanium Oxide Formed by Surfactant Bilayer Templating." J. Am. Chem. Soc. 120(27) (1998): 6832-6833. 
212. Fujii, Hiroyuki, Hirofumi Sato, Michitaka Ohtaki, Koichi Eguchi, and Hiromichi Arai. "Retarded Decomposition of the Trimethylammonium Moiety Observed on Photocatalytic Mineralization of Surfactants over $\mathrm{TiO}_{2}$ Photocatalyst." Chem. Lett. 3 (1998): 251-252.

213. Fujii, Toshiaki, Tsukuru Suzuki, and Kazuhiko Sakamoto. "Simultaneous Removal of Gases and Particulates by Photocatalyst and UV/Photoelectron Method." Kuki Seijo 35(3) (1997): 169-176.

214. Fujii, Toshiaki, Tsukuru Suzuki, Kazuhiko Sakamoto, Shin Yokoyama, and Masataka Hirose. "Super Cleaning of Closed Space by UV/Photoelectron Method Using Photocatalyst." Earozoru Kenkyu 13(2) (1998): 110-118.

215. Fujii, Toshiaki, Tukuru Suzuki, Kazuhiko Sakamoto, Shin Yokoyama, and Masataka Hirose. "Simultaneous Removal of Gaseous and Particulate Contaminants by a UV/Photoelectron Method Super-Cleaning of Mini-Environments.” Ebara Jiho 180 (1998): 3-14.

216. Fujishima, A., J. Ootsuki, T. Yamashita, and S. Hayakawa. "Behavior of Tumor Cells on Photoexcited Semiconductor Surface." Photomedicine and Photobiology 8(2) (1986): 45-46.

217. Fujishima, Akira. "Self-Cleaning Using $\mathrm{TiO}_{2}$ Photocatalyst." Denki Kagaku Oyobi Kogyo Butsuri Kagaku 64(10) (1996): 1052-1055.

218. Fujishima, Akira. "Photo-Cleaning Revolution by Photocatalytic Reaction." Kogyo Zairyo 45(10) (1997): 26-30.

219. Fujishima, Akira. "Water Treatment Using $\mathrm{TiO}_{2}$ Photocatalyst." Shigen Kankyo Taisaku 33(3) (1997): 241-245.

220. Fujishima, Akira and Shinoka Fujita. " $\mathrm{TiO}_{2}$ Photocatalyst for Water Treatment." J. Adv. Sci. 9(3-4) (1997): 192-195.

221. Fujishima, Akira, Larry A. Nagahara, Hajime Yoshiki, Katsuhiro Ajito, and Kazuhito Hashimoto. "Thin Semiconductor Films: Photoeffects and New Applications." Electrochim. Acta 39(8-9) (1994): 1229-1236.

222. Fujishima, Akira and Tata Narasinga Rao. "Recent Advances in Heterogeneous $\mathrm{TiO}_{2}$ Photocatalysis.” Proc. Indian Acad. Sci., Chem. Sci. 109(6) (1997): 471-486.

223. Fukayama, Shigemichi, Kazuo Ono, and Nobuo Kimura. "Development and Application of Photocatalytic Coating Materials." Toso to Toryo 575 (1998): 37-43.

224. Fukumori, Izumi. "Tendency of Development of Photocatalytic Coatings for Air Purification." Toso to Toryo 575 (1998): 31-36.

225. Gao, Tingyao, Hongbin Wei, and Dimin Xu. "Studies on Factors Affecting Photocatalytic Oxidation of Phenol with Titanium Dioxide Film." Zhongguo Jishui Paishui 14(4) (1998): $14-16,20$.

226. Gianturco, Franco, Claudia Maria Chiodaroli, Ignazio Renato Bellobono, Maria Luisa Raimondi, Alberto Moroni, and Berndt Gawlik. "Pilot-Plant Photomineralization of Atrazine in Aqueous Solution by Photocatalytic Membranes Immobilizing Titanium Dioxide and Promoting Photocatalysts." Fresenius Environ. Bull. 6(7-8) (1997): 461-68. 
227. Gianturco, Franco, Luca Vianelli, Luca Tatti, Fabrizio Rota, Paolo Bruzzi, Laura Rivas, and Ignazio Renato Bellobono. "Pilot-Plant Photomineralization of Dichloromethane and Tetrachloroethene in Aqueous Solution, by Photocatalytic Membranes Immobilizing Titanium Dioxide and Photopromoters." Chemosphere 33(8) (1996): 1531-1542.

228. Gimenez, Jaime, David Curco, and Pilar Marco. "Reactor Modeling in the Photocatalytic Oxidation of Wastewater.” Oxid. Technol. Water Wastewater Treat., Int. Conf., ed. Alfons Vogelpohl, Paper no. 45, Clausthal-Zellerfield, Germany: Papierflieger Verlag (1996).

229. Gimenez, Jaime, David Curco, and Pilar Marco. "Reactor Modeling in the Photocatalytic Oxidation of Wastewater." Water Sci. Technol. 35(4), Oxidation Technologies for Water and Wastewater Treatment (1997): 207-13.

230. Glatzmaier, Greg C. "Cost Comparison of Solar Detoxification with Conventional Alternatives for the Destruction of Trichloroethylene." Solar Engineering 1992, eds. William Stine, Jan Kreider, and Koichi Watanabe, New York, NY: ASME (1992): 43-49.

231. Gomes de Moraes, S. and W.F. Jardim. "Photocatalytic Degradation of the Wood Preservative Pentachlorophenol on $\mathrm{TiO}_{2}$ Particles: Identification and Toxicity of Intermediates." Proc. Braz. Symp. Chem. Lignins Other Wood Compon., 4th, eds. Eduardo Melo and Henrique Magalhaes, Recife, Brazil: Universidade Federal de Pernambuco, Centro de Tecnologia (1995): 87-92.

232. Gonzalez-Martin, Anuncia, and Reyimjan A. Sidik. "Efficient Photocatalytic Degradation of Organic Pollutants in the Liquid Phase by Titanium Dioxide." Proc. Electrochem. Soc. 98-5, Environmental Issues in the Electronics/Semiconductor Industries and Electrochemical/ Photochemical Methods for Pollution Abatement (1998): 193-200.

233. Gopalakrishnan, A.N. and V. Mohan. "Solar Photo Sensitizer Technology (SPS) for Dyeing Waste Reclamation.” Indian J. Environ. Prot. 17(4) (1997): 268-271.

234. Gopalakrishnan, A. Navaneetha and V. Mohan. "Solar Photo Sensitizer Technology for Wastewater Treatment.” Indian J. Environ. Prot. 17(7) (1997): 485-489.

235. Goslich, R., R. Dillert, and D. Bahnemann. "Solar Water Treatment." Oxid. Technol. Water Wastewater Treat., Int. Conf., ed. Alfons Vogelpohl, Paper no. 39, Clausthal-Zellerfeld, Germany: Papierflieger Verlag (1996).

236. Goslich, Roland, Ralf Dillert, and Detlef Bahnemann. "Solar Water Treatment: Principles and Reactors." Water Sci. Technol. 35(4), Oxidation Technologies for Water and Wastewater Treatment (1997): 137-148.

237. Goswami, D.Y. "A Review of Engineering Developments of Aqueous Phase Solar Photocatalytic Detoxification and Disinfection Processes.” J. Solar Energy Eng. 119(2) (1997): 101-113.

238. Goswami, D.Y., S.K. Sharma, G.D. Mathur, and C.K. Jotshi. "Techno-Economic Analysis of Solar Detoxification Systems.” J. Solar Energy Eng. 119(2) (1997): 108-113.

239. Goswami, D.Y., D.M. Trivedi, and S.S. Block. "Photocatalytic Disinfection of Indoor Air." J. Sol. Energy Eng. 119(1) (1997): 92-96. 
240. Goswami, D. Yogi, Klausner, G. D. Mathur, A. Martin, K. Schanze, P. Wyness, Craig T. Turchi, and E. Marchand. "Solar Photocatalytic Treatment of Groundwater at Tyndall AFB: Field Test Results." Solar 1993. Proceedings of the American Solar Energy Society Annual Conference, eds. S.M. Burley and M.E. Arden, Boulder, CO: ASES (1993): 235-239.

241. Goswami, T.K., S. Hingorani, H. Greist, M. Sankar, D.Y. Goswami, and S.S. Block. "Photocatalytic System to Decontaminate Indoor Air." Engineering Solutions to Indoor Air Quality Problems, Pittsburgh, PA: Air and Waste Management Association (1997): 339-344.

242. Goswami, Yogi. "Engineering of Solar Detoxification and Disinfection Processes." Advances in Solar Energy, ed. Karl W. Boer, 10. Boulder, CO: American Solar Energy Society (1995): 165-209.

243. Grabner, Gottfried, Guozheng Li, Ruth M. Quint, Raimund Quint, and Nikola Getoff. "Pulsed Laser-Induced Oxidation of Phenol in Acid Aquous $\mathrm{TiO}_{2}$." J. Chem. Soc. Faraday Trans. 87(8) (1991): 1097-1101.

244. Gratson, David A., Mark R. Nimlos, and Edward J. Wolfrum. "Photocatalytic Oxidation of GasPhase BTEX-Contaminated Waste Streams." Proc. 88th Annu. Meet. Air Waste Mgmt. Assoc., 95TP60P.04, 1995.

245. Grela, Maria A., Marta A. Brusa, and Agustin J. Colussi. "Harnessing Excess Photon Energy in Photoinduced Surface Electron Transfer between Salicylate and Illuminated Titanium Dioxide Nanoparticles." J. Phys. Chem. B 101(51) (1997): 10986-10989.

246. Grela, Maria A. and Agustin J. Colussi. "Kinetics of Stochastic Charge Transfer and Recombination Events in Semiconductor Colloids. Relevance to Photocatalysis Efficiency." J. Phys. Chem. 100(46) (1996): 18214-18221.

247. Guajardo, Rocio, Carlos Hernandez, Elisa Leyva, Alberto Lopez, and Edgar Moctezuma. "Photocatalytic Degradation of Chlorophenols on $\mathrm{TiO}_{2}$ Catalysts." Av. Ing. Quim. (1996) 5(3) (1995): 242-246.

248. Guillard, Chantal, Pierre Pichat, Gaspard Huber, and Can Hoang-Van. "The GC-MS Analysis of Organic Intermediates from the $\mathrm{TiO}_{2}$ Photocatalytic Treatment of Water Contaminated by Lindane (1.Alpha.,2.Alpha.,3.Beta.,4.Alpha.,5.Alpha.,6.Beta.- Hexachlorocyclohexane)." J. Adv. Oxid. Technol. 1(1) (1996): 53-60.

249. Gulyas, H., D. Bockelmann, L. Hemmerling, D. Bahnemann, and I. Sekoulov. "Treatment of Recalcitrant Organic Compounds in Oil Reclaiming Wastewater by Ozone/Hydrogen Peroxide and UV/Titanium Dioxide." Water Sci. Technol. 29(9) (1994): 129-132.

250. Guo, Weilin, Xikui Wang, Chongjuan Xu, Lisheng Zheng, and Shilong Wang. "Removal of Phenols in Aqueous Suspension of $\mathrm{TiO}_{2}$ by Photocatalytic Oxidation." Shandong Jiancai Xueyuan Xuebao 12(2) (1998): 107-108,114.

251. Ha, Heung Yong, and Marc A. Anderson. "Photodegradation of Organic Pollutants in Water Using Metal-Supported $\mathrm{TiO}_{2}$ Catalysts Prepared by Sol-Gel Techniques." Hwahak Konghak 34(3) (1996): $356-362$.

252. Halmann, Martin M. "Photodegradation of Water Pollutants." Boca Raton, FL: CRC Press, Inc. 
(1996).

253. Hanprasopwattana, A., S. Srinivasan, A.G. Sault, and A.K. Datye. "Titania Coatings on Monodisperse Silica Spheres (Characterization Using 2-Propanol Dehydration and TEM)." Langmuir 12(13) (1996): 3173-3179.

254. Hasegawa, Kiyoshi, Takaki Kanbara, and Shigehiro Kagaya. "Photocatalyzed Degradation of Agrochemicals in $\mathrm{TiO}_{2}$ Aqueous Suspensions.” Denki Kagaku Oyobi Kogyo Butsuri Kagaku 66(6) (1998): 625-634.

255. Hashimoto, Kazuhito. "Principle of Photocatalytic Reaction.” Kogyo Zairyo 45(10) (1997): 31-35.

256. Hashimoto, Kazuhito and Akira Fujishima. "Semiconductor Photoelectrode and Photocatalysis." Seramikkusu 31(10) (1996): 815-820.

257. Hashimoto, Kazuhito, Ken-ichi Ishibashi, and Akira Fujishima. " $\mathrm{TiO}_{2}$ Photocatalysis Using Weak UV Light.” Reza Kenkyu 25(6) (1997): 405-410.

258. Hattori, Akihiko, Miwako Yamamoto, Hiroaki Tada, and Seishiro Ito. "A Promoting Effect of $\mathrm{NH}_{4} \mathrm{~F}$ Addition on the Photocatalytic Activity of Sol-Gel TiO 2 Films." Chem. Lett. 8 (1998): 707-708.

259. He, Jianjun, Jincai Zhao, Hisao Hidaka, and Nick Serpone. "EPR Characteristics of a Dye/ Colloidal $\mathrm{TiO}_{2}$ System under Visible Light Irradiation.” J. Chem. Soc., Faraday Trans. 94(16) (1998): 23752378 .

260. Henschel, D. Bruce. "Cost Analysis of Activated Carbon versus Photocatalytic Oxidation for Removing Organic Compounds from Indoor Air.” J. Air \& Waste Mgmt. Assoc. 48 (1998): 985-994.

261. Henschel, D. Bruce. "Cost Analysis of Activated Carbon vs. Photocatalytic Oxidation for Removing VOCs from Indoor Air." 91st Annu. Meet. Air Waste Mgmt. Assoc., Air and Waste Management Association (1998).

262. Herrmann, J.-M., H. Tahiri, Y. Ait-Ichou, G. Lassaletta, A. R. Gonzalez-Elipe, and A. Fernandez. "Characterization and Photocatalytic Activity in Aqueous Medium of $\mathrm{TiO}_{2}$ and $\mathrm{Ag}-\mathrm{TiO}_{2} \mathrm{Coatings}$ on Quartz.” Appl. Catal. B 13(3/4) (1997): 219-228.

263. Herrmann, Jean-Marie, Jean Disdier, Pierre Pichat, Sixto Malato, and Julian Blanco. " $\mathrm{TiO}_{2}-\mathrm{Based}$ Solar Photocatalytic Detoxification of Water Containing Organic Pollutants. Case Studies of 2,4Dichlorophenoxyaceticacid (2,4-D) and of Benzofuran." Appl. Catal. B 17(1/2) (1998): 15-23.

264. Hess, Thomas F., Thomas A. Lewis, Ronald L. Crawford, Sudhakar Katamneni, John H. Wells, and Richard J. Watts. "Coupled Photocatalytic and Biological Degradation of 2,4,6-Trinitrotoluene (TNT).” In Situ On-Site Biorem., Pap. Int. In Situ On-Site Biorem. Symp., 4th, 2. Columbus, Ohio: Battelle Press (1997): 525-530.

265. Hess, Thomas F., Thomas A. Lewis, Ronald L. Crawford, Sudhakar Katamneni, John H. Wells, and Richard J. Watts. "Combined Photocatalytic and Fungal Treatment for the Destruction of 2,4,6Trinitrotoluene (TNT).” Water Res. 32(5) (1998): 1481-1491.

266. Hewett, Kevin B., Louis C. Anderson, Michael P. Rosynek, and Jack H. Lunsford. "Formation of Hydroxyl Radicals from the Reaction of Water and Oxygen over Basic Metal Oxides." J. Am. Chem. 
Soc. 118(29) (1996): 6992-6997.

267. Hidaka, H., S. Horikoshi, K. Ajisaka, J. Zhao, and N. Serpone. "Fate of Amino Acids upon Exposure to Aqueous Titania Irradiated with UV-A and UV-B Radiation Photocatalyzed Formation of $\mathrm{NH}_{3}, \mathrm{NO}_{3^{-}}$, and $\mathrm{CO}_{2} . "$ J. Photochem. Photobiol. A 108(2/3) (1997): 197-205.

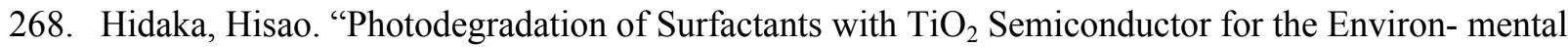
Wastewater Treatment." Proc. Indian Acad. Sci., Chem. Sci. 110(3) (1998): 215-228.

269. Hidaka, Hisao, Satoshi Horikoshi, Nick Serpone, and John Knowland. "In Vitro Photochemical Damage to DNA, RNA and Their Bases by an Inorganic Sunscreen Agent on Exposure to UVA and UVB Radiation.” J. Photochem. Photobiol. A 111(1-3) (1997): 205-214.

270. Hidaka, Hisao, Kayo Nohara, Jincai Zhao, Ezio Pelizzetti, Nick Serpone, Chantal Guillard, and Pierre Pichat. "Photodegradation of Surfactants. XVII. Photo-Oxidation Processes in Amphoteric Surfactants Catalyzed by Irradiated $\mathrm{TiO}_{2}$ Suspensions." J. Adv. Oxid. Technol. 1(1) (1996): 27-34.

271. Hilgendorff, Michael, Marcus Hilgendorff, and Detlef W. Bahnemann. "Mechanisms of Photocatalysis: the Reductive Degradation of Tetrachloromethane in Aqueous Titanium Dioxide Suspensions." J. Adv. Oxid. Technol. 1(1) (1996): 35-43.

272. Hill, Roger R., Graham E. Jeffs, and David R. Roberts. "Photocatalytic Degradation of 1,4-Dioxane in Aqueous Solution." J. Photochem. Photobiol. A 108(1) (1997): 55-58.

273. Hilmi, Abdelkader, John H.T. Luong, and An-Lac Nguyen. "Applicability of Capillary Electrophoresis with Amperometric Detection to Study Degradation of Chlorophenols in Contaminated Soil.” Environ. Sci. Technol. 31(6) (1997): 1794-1800.

274. Hilmi, Abdelkader, John H.T. Luong, and An-Lac Nguyen. "Applicability of Micellar Electrokinetic Chromatography to Kinetic Studies of Photocatalytic Oxidation of Dibenzo-p-Dioxin." Chemosphere 36(15) (1998): 3113-3117.

275. Hilmi, Abdelkader, John H.T. Luong, and An-Lac Nguyen. "Capillary Electrophoresis Applied to Kinetic Studies of Photocatalytic Oxidation of Substituted Anilines." Chemosphere 36(15) (1998): $3137-3147$.

276. Hirano, Katsuhiko, Hideo Asayama, Akio Hoshino, and Hiroshi Wakatsuki. "Metal Powder Addition Effect on the Photocatalytic Reactions and the Photo-Generated Electric Charge Collected at an Inert Electrode in Aqueous $\mathrm{TiO}_{2}$ Suspensions." J. Photochem. Photobiol. A 110(3) (1997): $307-311$.

277. Hitchman, Michael L., R. Anthony Spackman, and Cesar Agra. "Photoelectrochemical Study of Titanium Dioxide Films Prepared by Anodization of Titanium Metal in Sulfuric Acid." J. Chem. Soc., Faraday Trans. 92(20) (1996): 4049-4052.

278. Hodak, Jose, Cecilia Quinteros, Marta I. Litter, and Enrique San Roman. "Sensitization of $\mathrm{TiO}_{2}$ with Phthalocyanines. Part 1. Photooxidations Using Hydroxoaluminium Tricarboxymonoamidephthalocyanine Adsorbed on $\mathrm{TiO}_{2}$." J. Chem. Soc., Faraday Trans. 92(24) (1996): 5081-5088. 
279. Holland, Brian T., Christopher Blanford, and Andreas Stein. "Synthesis of Macroporous Minerals with Highly Ordered Three-Dimensional Arrays of Spheroidal Voids." Science 281(5376) (1998): $538-540$.

280. Honda, H., A. Ishizaki, R. Soma, K. Hashimoto, and A. Fujishima. "Application of Photocatalytic Reactions Caused by $\mathrm{TiO}_{2}$ Film to Improve the Maintenance Factor of Lighting Systems." J. Illum. Eng. Soc. 27(1) (1998): 42-49.

281. Hong, Chia-Swee, Yongbing Wang, and Brian Bush. "Kinetics and Products of the $\mathrm{TiO}_{2}$ Photocatalytic Degradation of 2-Chlorobiphenyl in Water." Chemosphere 36(7) (1998): 16531667.

282. Horie, Y., M. Taya, and S. Tone. "Photocatalytic Sterilization of Microbial Cells with Titania Thin Film Prepared by Sol-Gel Method.” Kagaku Kogaku Ronbunshu 22(5) (1966): 1241-1245.

283. Horie, Yasuhiko, Diago Abreu David, Masahito Taya, and Setsuji Tone. "Effects of Light Intensity and Titanium Dioxide Concentration on Photocatalytic Sterilization Rates of Microbial Cells." Ind. Eng. Chem. Res. 35(11) (1996): 3920-3926.

284. Horie, Yasuhiko, Masahito Taya, and Setsuji Tone. "Effect of Cell Adsorption on Photosterilization of Escherichia coli over Titanium Dioxide-Activated Charcoal Granules." J. Chem. Eng. Jpn. 31(6) (1998): 922-929.

285. Horie, Yasuhiko, Masahito Taya, and Setsuji Tone. "Evaluation of Photocatalytic Sterilization Rates of Escherichia coli Cells in Titanium Dioxide Slurry Irradiated with Various Light Sources." J. Chem. Eng. Jpn. 31(4) (1998): 577-584.

286. Horikoshi, Satoshi and Hisao Hidaka. "Photodegradation of Polymer Materials Catalyzed by $\mathrm{TiO}_{2}$ Semiconductor." Shikizai Kyokaishi 71(3) (1998): 176-185.

287. Horikoshi, Satoshi, Nick Serpone, Yoshiharu Hisamatsu, and Hisao Hidaka. "Photocatalyzed Degradation of Polymers in Aqueous Semiconductor Suspensions. 3. Photooxidation of a Solid Polymer: $\mathrm{TiO}_{2}$-Blended Poly(Vinyl Chloride) Film." Environ. Sci. Technol. 32(24) (1998): 4010 4016.

288. Horikoshi, Satoshi, Nick Serpone, Jincai Zhao, and Hisao Hidaka. "Towards a Better Understanding of the Initial Steps in the Photocatalyzed Mineralization of Amino Acids at the Titania/Water Interface. An Experimental and Theoretical Examination of L-Alanine, L-Serine and LPhenylalanine." J. Photochem. Photobiol. A 118(2) (1998): 123-29.

289. Hoshi, Koji, and Hirofumi Nameki. "Development of Porous Sound-Absorbing Ceramics with $\mathrm{TiO}_{2}$ Photocatalyst by Recycling of Industrial Waste." Shigen Kankyo Taisaku 34(2) (1998): $173-177$.

290. Hoshi, Koji and Hirofumi Nameki. "Development of Sound-Adsorbing Boards Containing Photocatalysts Prepared Using Melted Slag from Sewage Sludge as Air-Purification System." Nenryo Oyobi Nensho 65(7) (1998): 483-489.

291. Hoshi, Koji, Hirofumi Nameki, Masayoshi Fukazawa, and Toru Kuno. "Development of Ceramics for Removing Pollutants from Environment (Part V) -- Development of Porous Sound-Absorbing 
Ceramics with $\mathrm{TiO}_{2}$ Photocatalyst." Aichi-Ken Tokoname Yogyo Gijutsu Senta Hokoku 24 (1997): 912.

292. Hoshi, Koji, Hirofumi Nameki, and Tatsuo Yamazaki. "Development of Ceramics for Removing Pollutants from Environment (Part VI) -- Development of Sound-Absorbing Ceramics with $\mathrm{TiO}_{2}$ Photocatalyst by Recycling Fused Sewage Slag and NOx Removal System." Aichi-Ken Tokoname Yogyo Gijutsu Senta Hokoku 25 (1998): 1-6.

293. Hoshi, Koji, Tomohiro Yamaguchi, Masayoshi Fukazawa, and Toru Kuno. "Development of Ceramics for Removing Pollutants from Environment. Part II. Development of Porous Ceramics for $\mathrm{TiO}_{2}$ Photocatalysts.” Aichi-Ken Tokoname Yogyo Gijutsu Senta Hokoku 23 (1996): 12-15.

294. Hoshikawa, Takeshi, Masakazu Tada, Shunichi Kiduki, and Keisuke Mita. "Transmittance and Photocatalytic Activity of the Float Glasses Coated with $\mathrm{TiO}_{2}$ Thin Film." Kagaku to Kogyo 72(3) (1998): 124-130.

295. Hossain, Md. Moazzem and Gregory B. Raupp. "Radiation Field Modeling in a Photocatalytic Monolith Reactor.” Chem. Eng. Sci. 53(22) (1998): 3771-3780.

296. Hotsenpiller, P.A. Morris, J.D. Bolt, W.E. Farneth, J.B. Lowekamp, and G.S. Rohrer. "Orienta- tion Dependence of Photochemical Reactions on $\mathrm{TiO}_{2}$ Surfaces." J. Phys. Chem. B 102(17) (1998): 3216-3226.

297. $\mathrm{Hu}$, Chun, Yizhong Wang, and Hongxiao Tang. "Kinetics of Photocatalytic Oxidation of Phenol on $\mathrm{TiO}_{2}$." Huanjing Kexue 18(4) (1997): 3-4.

298. Hua, Zhaozhe, Jian Chen, Lijie Li, Shiyi Lun, and Shiraishi Fumihide. "Study on Degradation of Typical Contaminant 2,4-DNP with New Photocatalytic Reactor." Wuxi Qinggong Daxue Xuebao 17(3) (1998): 66-69.

299. Huang, Min. Factors Affecting the Catalyst Activities of $\mathrm{TiO}_{2}$-Based Aqueous Phase Photocatalytic Reaction. Ph.D. diss., Univ. of New Mexico, 1998.

300. Huang, Ning-Ping, Min-Hua Xu, Chun-Wei Yuan, and Rui-Rong Yu. "The Study of the Photokilling Effect and Mechanism of Ultrafine $\mathrm{TiO}_{2}$ Particles on U937 Cells." J. Photochem. and Photobiol. A: Chem. 108 (1997): 229-233.

301. Huang, Zheng, Pin-Ching Maness, Daniel M. Blake, William A. Jacoby, Edward J. Wolfrum, and Sharon L. Smolinski. "New Mode of Bactericidal Activity of Titanium Dioxide Photocatalyst." J. Photochem. Photobiol. A: Chem. (1999): Submitted for publication.

302. Hung, Chung-Hsuang, and Benito J. Marinas. "Role of Chlorine and Oxygen in the Photocatalytic Degradation of Trichloroethylene Vapor on $\mathrm{TiO}_{2}$ Films." Environ. Sci. Technol. 31(2) (1997): 562-568.

303. Hung, Chung-Hsuang and Benito J. Marinas. "Role of Water in the Photocatalytic Degradation of Trichloroethylene Vapor on $\mathrm{TiO}_{2}$ Films." Environ. Sci. Technol. 31(5) (1997): 1440-1445.

304. Hung, Chung-Hsuang and Chung-Shin Yuan. "Gas-Phase Photocatalytic Degradation of Perchloroethylene on Glass Pellets Immobilized with $\mathrm{TiO}_{2}$." Proc. Annu. Meet. Air Waste Mgmt. Assoc., 91st (1998): WA47B06/1-WA47B06/13. 
305. Hung, Chung-Hsung and Benito J. Marinas. "Photocatalytic Degradation of Hazardous Air Pollutants on Anatase $\mathrm{TiO}_{2}$ Thin Films." Emerging Solutions VOC Air Toxics Control, Proc. Spec. Conf., Pittsburgh, Pa: Air \& Waste Management Association (1996): 375-385.

306. Huo, Aiqun, Xin Tan, Peijin Cong, and Chunyou Ma. "Relationship between $\mathrm{TiO}_{2}-\mathrm{x}$ Nanocrystalline Defect Structure and Its Photocatalysis Characteristics.” Huaxue Tongbao 11 (1998): 31 32 .

307. Huo, Aiqun, Xin Tan, and Peijun Cong. "Application of Nanoscale $\mathrm{TiO}_{2}$ Photocatalyst Mem- brane in Degradation of Atrazine in Wastewater." Gongye Shuichuli 18(3) (1998): 25-26,29.

308. Hustert, Klaus and Pran Nath Moza. "Photochemical Degradation of Dicarboximmide Fungicides in the Presence of Soil Constituents." Chemosphere 35(1/2) (1997): 33-37.

309. Hwang, Son-Jong, Chris Petucci, and Daniel Raftery. "In Situ Solid-State NMR Observations of Photocatalytic Surface Chemistry: Degradation of Trichloroethylene.” J. Am. Chem. Soc. 119(33) (1997): 7877-7878.

310. Hyun, Sang-Hoon and Kee-Hong Lee. "Oxidation of Organic Compounds through the Electrochemical Reaction Using $\mathrm{TiO}_{2}$ Photocatalytic Membranes.” Memburein 6(2) (1996): 101-108.

311. Ichihashi, Y., H. Yamashita, and M. Anpo. "Relationship between the Local Structures of Titanium Oxide Photocatalysts and Their Reactivities - XAFS, UV, Photoluminescence and Photoreaction Investigations." J. Phys. IV 7(C2), X-Ray Absorption Fine Structure, vol. 2 (1997): 883-85.

312. Ichihashi, Yuichi, Hiromi Yamashita, and Masakazu Anpo. "The In-Situ Characterization of Titanium Oxides Prepared in the Zeolite Cavities and Framework and Their Photocatalytic Reactivities for the Direct Decomposition of NO into $\mathrm{N}_{2}$ at 275K." Stud. Surf. Sci. Catal. 105B, Progress in Zeolite and Microporous Materials, Pt. B (1997): 1609-1616.

313. Ichihashi, Yuichi, Shuguo Zhang, Hiromi Yamashita, and Masakazu Anpo. "Photocatalytic Reactions in the Micropores of Zeolites. Part 2. Photocatalytic Reactions on Highly Dispersed Titanium Oxide and Vanadium Oxide Catalysts." Hyomen 34(9) (1996): 516-526.

314. Ichinose, Hiromichi. "Neutral Titania Coating Materials. Peroxotitanate Solutions and PeroxoModified Anatase Sol. Development and Characteristics." Toso to Toryo 555 (1996): 27-31.

315. Ida, Jun-ichi, Ichirou Fukai, Tatsushi Matsuyama, and Hideo Yamamoto. "Titania Coating of Glass Beads for Packed Bed Photocatalytic Reactor." World Congr. Part. Technol. 3, Rugby, UK.: Institution of Chemical Engineers (1998): 4078-4083.

316. Ihara, Tatsuhiko, Satoshi Watanabe, Seishiro Ito, and Mitsuo Kiboku. "Surface Modification of Titania Particles by Ceria for Increasing UV-Shielding Effect and Suppression of Photocata- lytic Activity - Effect of Pretreatment by TEOS Adsorption.” Shikizai Kyokaishi 71(11) (1998): 671-77.

317. Ikeda, Katsuyoshi, Kazuhito Hashimoto, and Akira Fujishima. "Role of Oxygen in Photocatalytic Reaction." Kokagaku 22 (1996): 54-58. 
318. Ikeda, Katsuyoshi, Kazuhito Hashimoto, and Akira Fujishima. "Comparative Studies on the Photocatalytic Decomposition of Ethanol and Acetaldehyde in Water Containing Dissolved Oxygen Using a Microelectrode Technique.” J. Electroanal. Chem. 437(1/2) (1997): 241-44.

319. Inel, Y. and A.N. Okte. "Photocatalytic Degradation of Succinic Acid in Aqueous Suspensions of Titanium Dioxide. An Initial Kinetic Investigation of $\mathrm{CO}_{2}$ Photogeneration.” Toxicol. Environ. Chem. 55(1-4) (1996): 115-126.

320. Inel, Y. and A.N. Okte. "Photodegradation Kinetics of Adipic Acid in the Presence of $\mathrm{TiO}_{2}$." Toxicol. Environ. Chem. 65(1-4) (1998): 123-133.

321. Inel, Yuksel and Ayse Neren Okte. " $\mathrm{TiO}_{2}$ Sensitized Photomineralization Kinetics of Phthalic Anhydride.” Chemosphere 36(14) (1998): 2969-2975.

322. Ingler, William B., Jr., Shahed, U.M. Khan, Anthony J. Perrotta, and Christopher J. Retaride. "Photocatalytic and Photoelectrochemical Oxidation of Organics in Kwinana Lake Water by $\mathrm{N}-\mathrm{TiO}_{2}$ Powder and $\mathrm{N}-\mathrm{TiO}_{2} / \mathrm{n}-\mathrm{SnO}_{2}$ Thin Film Electrodes." Proc. Electrochem. Soc. 98-5, Environmental Issues in the Electronics/Semiconductor Industries and Electrochemical/ Photochemical Methods for Pollution Abatement (1998): 201-212.

323. Ishida, Tasaku, Hajime Murakami, and Koichi Yamaguchi. "Self-Cleaning Deodorizing Filter Using Photocatalytic Titanium Dioxide (P-ST Filter)." Kino Zairyo 17(1) (1997): 5-12.

324. Ishii, Hidekazu, Saulius Juodkazis, Shigeki Matsuo, and Hiroaki Misawa. "Photoelectrochemical Fabrication of Submicrometer Platinum Pattern on Titanium Dioxide Single Crystal Surface." Chem. Lett. 7 (1998): 655-656.

325. Isidorov, V., E. Klokova, V. Povarov, and S. Kolkova. "Photocatalysis on Atmospheric Aerosols: Experimental Studies and Modeling." Catal. Today 39(3) (1997): 233-242.

326. Ito, Yoshimasa. "Metal Titanium Photocatalyst Materials.” Kogyo Zairyo 45(10) (1997): 59-61.

327. Ivanov, V.P., D.I. Kochubey, K.P. Kutzenogii, and N.S. Bufetov. "Surface Composition of Atmospheric Aerosols." React. Kinet. Catal. Lett. 64(1) (1998): 97-102.

328. Iwao, Masatoshi, Takashi Ando, and Toshihiro Takehama. "Photocatalytic Deodorization of Refrigeration Vehicles.” Kogyo Zairyo 45(10) (1997): 89-91.

329. Jacoby, William A., Daniel M. Blake, John A. Fennell, James E. Boulter, LeAnn M. Vargo, Marya C. George, and Suzanne K. Dolberg. "Heterogeneous Photocatalysis for Control of Vol atile Organic Compounds in Indoor Air." J. Air Waste Mgmt. Assoc. 46(9) (1996): 891-898.

330. Jacoby, William A., Daniel M. Blake, and Andrew S. Watt. "Trichloroethylene or Perchloroethylene Contamination, Remediation of." Encyclopedia of Environmental Analysis and Remediation, ed. Robert A. Meyers, New York, NY: John Wiley and Sons (1998): 4847-4873.

331. Jacoby, William A., Pin Ching Maness, Edward J. Wolfrum, Daniel M. Blake, and John A. Fennell. "Mineralization of Bacterial Cell Mass on a Photocatalytic Surface in Air." Environ. Sci. Technol. 32(17) (1998): 2650-2653.

332. Jafar Mahmood, A., M. Muhibur Rahman, and M.M. Hossain. "Studies on $\mathrm{TiO}_{2}$-Mediated Photodegradation of Procion Red (PR).” J. Bangladesh Chem. Soc. 9(2) (1996): 229-237. 
333. Jardim, W.F., S.G. Moraes, and M.M.K. Takiyama. "Photocatalytic Degradation of Aromatic Chlorinated Compounds Using $\mathrm{TiO}_{2}$ : Toxicity of Intermediates.” Water Res. 31(7) (1997): 17281732 .

334. Jing, Bingwen, Hong Zhang, Manhua Zhang, Zhuhong Lu, and Tao Shen. "Ruthenium(II) Thiocyanate Complexes Containing 4'-(4-Phosphonatophenyl)- 2,2':6',2"'-Terpyridine: Synthesis, Photophysics and Photosensitization of Nanocrystalline $\mathrm{TiO}_{2}$ Electrodes." J. Mater. Chem. 8(9) (1998): 2055-2060.

335. Jones, Alexander P. and Richard J. Watts. "Dry Phase Titanium Dioxide-Mediated Photo- catalysis: Basis for In Situ Surface Destruction of Hazardous Chemicals.” J. Environ. Eng. 123(10) (1997): 974-981.

336. Jorgensen, Gary and Rangaprasad Govindaragan. "Ultraviolet Reflector Materials for Solar Detoxification of Hazardous Waste." Opt. Mater. Technol. for Energy Effic. Solar Energy Convers. $X$, eds. Carl M. Lampert and Claes G. Granqvist, Proceedings Society of Optical Engineering, SPIE (1991): 194-205.

337. Kado, Yoshifumi, Mahito Atobe, and Tsutomu Nonaka. "Ultrasonic Effects on Electroorganic Processes XII. Oxidation of 2-Propanol on a $\mathrm{TiO}_{2}$ Photocatalyst." Denki Kagaku Oyobi Kogyo Butsuri Kagaku 66(7) (1998): 760-762.

338. Kagaya, Shigehiro, Yoshiro Bitoh, and Kiyoshi Hasegawa. "Photocatalyzed Degradation of MetalEDTA Complexes in $\mathrm{TiO}_{2}$ Aqueous Suspensions and Simultaneous Metal Removal." Chem. Lett. 2 (1997): 155-156.

339. Kakita, Yukari, Nobuhiro Kashige, Fumio Miake, and Kenji Watanabe. "Photocatalysis-Dependent Inactivation of Lactobacillus Phage PL-1 by a Ceramics Preparation." Biosci. Biotech. Biochem. 61(10) (1997): 1947-1948.

340. Kaneco, Satoshi, Hidekazu Kurimoto, Kiyohisa Ohta, Takayuki Mizumo, and Akira Saji. "Photocatalytic Reduction of $\mathrm{CO}_{2}$ Using $\mathrm{TiO}_{2}$ Powders in Liquid $\mathrm{CO}_{2}$ Medium." J. Photochem. Photobiol. A 109(1) (1997): 59-63.

341. Kaneco, Satoshi, Yasuhiro Shimizu, Kiyohisa Ohta, and Takayuki Mizuno. "Photocatalytic Reduction of High Pressure Carbon Dioxide Using $\mathrm{TiO}_{2}$ Powders with a Positive Hole Scavenger." J. Photochem. Photobiol. A 115(3) (1998): 223-226.

342. Karakulski, K., W.A. Morawski, and J. Grzechulska. "Purification of Bilge Water by Hybrid Ultrafiltration and Photocatalytic Processes.” Sep. Purif. Technol. 14(1-3) (1998): 163-73.

343. Kasuga, Tomoko, Masayoshi Hiramatsu, Masayoshi Hirano, Akihiko Hoson, and Kyoko Oyamada. "Preparation of $\mathrm{TiO}_{2}$-Based Powders with High Photocatalytic Activities." J. Mater. Res. 12(3) (1997): 607-609.

344. Kaufman, Arlen D., Peter T. Kissinger, and Jay E. Jones. "The Use of Titanium Dioxide as a PhotoCatalyst to Improve the Sensitivity of Post-Column Photolysis-Electrochemical Detection for Microbore Liquid Chromatography." Anal. Chim. Acta 356(2/3) (1997): 177-86. 
345. Kawano, Kazutada, Hideaki Katou, Takezirou Uehara, and Katsuhiko Hirano. "Measurement of the Size of Semiconductor Particles and Quantum Size Effect on Photocatalysis." Kagaku to Kyoiku 46(12) (1998): 796-799.

346. Kelly, B.D. and P. De Laquil. "Conceptual Design of a Photocatalytic Wastewater Treatment Plant." Solar Engineering 1992, eds. William Stine, Jan Kreider, and Koichi Watanabe, New York, NY: ASME (1992): 65-69.

347. Kennedy, James C. III and Abhaya K. Datye. "Photothermal Heterogeneous Oxidation of Ethanol over Pt/TiO $2 . " J$. Catal. 179(2) (1998): 375-389.

348. Kennedy, James Charles III. Photothermal Synergisms in Heterogeneous Gas Phase Ethanol Oxidation over $\mathrm{TiO}_{2}$ and $\mathrm{Pt} / \mathrm{TiO}_{2}$ (Titanium Oxide, Platinum, Photocatalysis). Ph.D. diss., Univ. of New Mexico (1997).

349. Kenneke, John Frederick. The Titanium Dioxide Mediated Photodegradation of Chloroalkenes in Water. Ph.D. diss., Univ. of North Carolina (1996).

350. Kersters, Ilse, Tilly De Keyser, and Willy Verstraete. "Sensitivity of Bacteria to Photoactivated Titanium Dioxide in Comparison with UV Irradiation." Indian J. Eng. Mater. Sci. 5(4) (1998): $211-$ 216.

351. Kesselman, J.M., Nathan S. Lewis, Oleh Weres, and Michael R. Hoffmann. "Polycrystalline $\mathrm{TiO}_{2}$ Electrodes: Electrochemical Production of .Cntdot.OH and Oxidation of Aqueous Organic Pollutants." Oxid. Technol. Water Wastewater Treat., Int. Conf., ed. Alfons Vogelpohl, Paper no. 63, Clausthal-Zellerfield, Germany: Papierflieger Verlag (1996).

352. Kesselman, Janet M., Nathan S. Lewis, and Michael R. Hoffmann. "Photoelectrochemical Degradation of 4-Chlorocatechol at $\mathrm{TiO}_{2}$ Electrodes: Comparison between Sorption and Photoreactivity." Environ. Sci. Technol. 31(8) (1997): 2298-2302.

353. Kesselman, Janet M., Oleh Weres, Nathan S. Lewis, and Michael R. Hoffmann. "Electrochemical Production of Hydroxyl Radical at Polycrystalline Nb-Doped $\mathrm{TiO}_{2}$ Electrodes and Estimation of the Partitioning between Hydroxyl Radical and Direct Hole Oxidation Pathways." J. Phys. Chem. B 101(14) (1997): 2637-2643.

354. Kesselman, Janet Marie. Fundamental Photoelectrochemical Properties of $\mathrm{TiO}_{2} /$ Water Interfaces: Relevance for Hazardous Waste Remediation (Titanium Dioxide, Niobium, Photocatalysis). Ph.D. diss., California Institute of Technology (1997).

355. Khalil, L.B., W.E. Mourad, and M.W. Rophael. "Photocatalytic Reduction of Environmental Pollutant Cr(VI) over Some Semiconductors under UV/Visible Light Illumination.” Appl. Catal. B 17(3) (1998): 267-273.

356. Kikuchi, Yoshihiko, Kayano Sunada, Tomokazu Iyoda, Kazuhito Hashimoto, and Akira Fujishima. "Photocatalytic Bactericidal Effect of $\mathrm{TiO}_{2}$ Thin Films: Dynamic View of the Active Oxygen Species Responsible for the Effect." J. Photochem. and Photobiol. A: Chem. 106 (1997): 51-56.

357. Kim, Dong H., Tai K. Lee, Kyung N. Kim, P. Chungmoo Auh, Kwang B. Kim, and Seung W. Lee. "The Enhancement of Redox Reactions with Mixed Oxide Catalysts by the Sol Gel Process." Oxid. Technol. Water Wastewater Treat., Int. Conf., ed. Alfons Vogelpohl, Paper no. 54, ClausthalZellerfield, Germany: Papierflieger Verlag, 1996. 
358. Kim, Dong Hyun, Tomokazu Iyoda, Kazuhito Hashimoto, and Akira Fujishima. "Activity, and Hardness of Supported $\mathrm{TiO}_{2}$ Films on Pyrex and Soda-Lime Glass in Photocatalytic Degradation of Formic Acid for 50 Days." J. Adv. Oxid. Technol. 3(2) (1998): 134-137.

359. Kim, Jong-Soon, Kiminori Itoh, and Masayuki Murabayashi. "Effects of Pretreatment of $\mathrm{TiO}_{2}$ Thin Films on the Gas-Phase Photocatalytic Reaction of Trichloroethylene." Denki Kagaku Oyobi Kogyo Butsuri Kagaku 64(11) (1996): 1200-1202.

360. Kim, Ki Young and Seung Bin Park. "Photocatalytic Activity of Anatase Titania Particles of Controlled Size Prepared in an Aerosol Reactor.” Hwahak Konghak 36(1) (1998): 116-119.

361. Kim, Kyung N., Dong H. Kim, Myung S. Jeon, and Tai K. Lee. "Heterogeneous Photocatalytic Degradation of Ethylene Glycol and Propylene Glycol." Oxid. Technol. Water Wastewater Treat., Int. Conf., ed. Alfons Vogelpohl, Paper no. 53, Clausthal-Zellerfield, Germany: Papierflieger Verlag (1996).

362. Kisch, Horst, Ling Zang, Christian Lange, Wilhelm F. Maier, Christina Antonius, and Dieter Meissner. "Heterogeneous Photocatalysis. Part 18. Modified, Amorphous Titania - a Hybrid Semiconductor for Detoxification and Current Generation by Visible Light." Angew. Chem., Int. Ed. 37(21) (1998): 3034-3036.

363. Kishimoto, Hirotsugu, Koichi Takahama, Noboru Hashimoto, Yoshifumi Aoi, and Shigehito Deki. "Photocatalytic Activity of Titanium Oxide Prepared by Liquid Phase Deposition (LPD)." J. Mater. Chem. 8(9) (1998): 2019-2024.

364. Kitamura, Masanori and Yuko Fujita. "Optimization of Photocatalytic Flow Reactor Using $\mathrm{TiO}_{2}$ and in Decomposition of 2-Methylisoborneol and Geosmin in Water." GS News Tech. Rep. 56(1) (1997): $39-44$.

365. Kiwi, J. "Role of Oxygen at the $\mathrm{TiO}_{2}$ Interface during Photodegradation of Biologically Difficult-toDegrade Sulfonate Dyes.” Environ. Toxic. Chem. 95 (1995): 1569-1575.

366. Klapproth, Alice, Sandy Linnemann, Detlef Bahnemann, Ralf Dillert, and Gregor Fels. “

${ }^{14}$ C-Trinitrotoluene: Synthesis and Photocatalytic Degradation.” J. Labelled Compd. Radiopharm. 41(4) (1998): 337-343.

367. Kobayashi, Eiichi, Goro Mizutani, and Sukekatsu Ushioda. "Surface Optical Second Harmonic Generation from Rutile $\mathrm{TiO}_{2}(110)$ in Air." Jpn. J. Appl. Phys., Part 1 36(12A) (1997): 7250-7256.

368. Kobayashi, Masaru and William Kalriess. "Photocatalytic Activity of Titanium Dioxide and Zinc Oxide. The Effect of Organic and Inorganic Surface Treatments." Cosmet. Toiletries 112(6) (1997): $83-86$.

369. Kominami, Hiroshi, Jun-ichi Kato, Masaaki Kohno, Yoshiya Kera, and Bunsho Ohtani. "Photocatalytic Mineralization of Acetic Acid (HOAc) in Aerated Aqueous Suspension of UltraHighly Active Titanium(IV) Oxide Prepared by Hydrothermal Crystallization in Toluene." Chem. Lett. 12 (1996): 1051-1052.

370. Komoda, Y., N. Sakai, Tata N. Rao, D.A. Tryk, and A. Fujishima. "Photoelectrorheological Phenomena Involving $\mathrm{TiO}_{2}$ Particle Suspensions.” Langmuir 14(5) (1998): 1081-1091.

371. Komoto, Masahiro. "Development and Application of Micro-Titanium Dioxide." Kagaku Kogyo 
48(12) (1997): 981-986.

372. Koreto, Takeshi. “Titanium Oxide Photocatalyst Materials, ST Series.” Kogyo Zairyo 45(10) (1997): $36-41$.

373. Koretou, Takeshi and Senji Kaji. "Photocatalytic Titanium Dioxide Which Oxidation-Decomposes Hard Decomposable Materials.” Kogyo Zairyo 45(7) (1997): 65-67.

374. Kormann, Claudius, Detlef W. Bahnemann, and Michael R. Hoffmann. "Photocatalytic Production of Hydrogen Peroxides and Organic Peroxides in Aqueous Suspensions of Titanium Dioxide, Zinc Oxide, and Desert Sand." Environ. Sci. Technol. 22(7) (1988): 798-806.

375. Kormann, Claudius, Detlef W. Bahnemann, and Michael R. Hoffmann. "Preparation and Characterization of Quantum-Size Titanium Dioxide.” J. Phys. Chem. 92(18) (1988): 5196-5201.

376. Kosanic, Miroslav M. "Photocatalytic Degradation of Organic Compounds in Water." Proc. Fac. Technol., Novi Sad, vol. 1995-1996 (1996): 26-27,133-149.

377. Koval, Carl A., Karen J. Buechler, Richard D. Noble, Theresa Zawistowski, and William A. Jacoby. "Effects of Controlled Periodic Illumination on Photocatalytic Reactions at $\mathrm{TiO}_{2}$ Films." Proc. Electrochem. Soc., 98-5, Environmental Issues in the Electronics/Semiconductor Industries and Electrochemical/Photochemical Methods for Pollution Abatement (1998): 144-149.

378. Krysova, Hana, Josef Krysa, Katerina Macounova, and Jaromir Jirkovsky. "Photocatalytic Degradation of Diuron [3-(3,4- Dichlorophenyl)-1,1-Dimethylurea] on the Layer of $\mathrm{TiO}_{2}$ Particles in the Batch Mode Plate Film Reactor.” J. Chem. Technol. Biotechnol. 72(2) (1998): 169-175.

379. Ku, Young and In-Liang Jung. "Decomposition of Monocrotophos in Aqueous Solution by UV Irradiation in the Presence of Titanium Dioxide." Chemosphere 37(13) (1998): 2589-2597.

380. $\mathrm{Ku}$, Young, Ren-Ming Leu, and Kuen-Chyr Lee. "Decomposition of 2-Chlorophenol in Aqueous Solution by UV Irradiation with the Presence of Titanium Dioxide." Water Res. 30(11) (1996): 2569-2578.

381. Kubota, Y., M. Hosaka, K. Hashimoto, and A. Fujishima. "Application of Photoexcited $\mathrm{TiO}_{2}$ Particle to Regional Cancer Treatment: A New Approach.” Reg. Cancer Treat. 8 (1995): 192-197.

382. Kubota, Y., T. Shuin, C. Kawasaki, M. Hosaka, H. Kitamura, R. Cai, H. Sakai, K. Hashimoto, and A. Fujishima. "Photokilling of T-24 Human Bladder Cancer Cells with Titanium Dioxide." Br. J. Cancer 70 (1994): 1107-1111.

383. Kudo, Akihiko and Hidemasa Nagayoshi. "Photocatalytic Reduction of $\mathrm{N}_{2} \mathrm{O}$ on Metal-Supported $\mathrm{TiO}_{2}$ Powder at Room Temperature in the Presence of $\mathrm{H}_{2} \mathrm{O}$ and $\mathrm{CH}_{3} \mathrm{OH}$ Vapor." Catal. Lett. 52(1/2) (1998): 109-111.

384. Kumar, Shiva and Allen P. Davis. "Heterogeneous Photocatalytic Oxidation of Nitrotoluenes." Water Environ. Res. 69(7) (1997): 1238-1245.

385. Kuo, Chao-Yin and Shang-Lien Lo. "Adsorption of Aqueous 4-Chlorobiphenyl and Treatment With UV-Illuminated Titanium Dioxide.” J. Colloid Interface Sci. 196(2) (1997): 199-206. 
386. Kurshev, Vadim and Larry Kevan. "Comparison of Photoelectron Transfer between Ru(Bpy)32+ and MV2+ in $\mathrm{TiO}_{2}$ and $\mathrm{SnO}_{2}$ Colloids and Dihexadecyl Phosphate Vesicles." Langmuir 13(2) (1997): 225-228.

387. Kusunoki, K., T. Oku, I.H. Kon, K. Nakaya, T. Mori, Y. Hiratuka, M. Taguchi, Y. Watanabe, and T. Miyake. "A Study on the Effect of the Solar Energy Toothbrush on the Control of Dental Plaque." $J$. Osaka Odont. Soc. 49 (1986): 550-559.

388. Kutscher, C., R. Davenport, R. Farrington, G. Jorgensen, A. Lewandowski, and C. Vineyard. LowCost Collectors/Systems Development Progress Report, SERI/RR-253-1750. SERI, Golden, CO (1984). NTIS.

389. Kuznetsova, N.A., V.N. Anosov, N.S. Gretsova, V.M. Negrimovskii, and O.L. Kaliya. "Sensitization of Titanium Dioxide to Visible Light by Dyes of the Phthalocyanine Series." Zh. Fiz. Khim. 71(9) (1997): 1690-1694.

390. Kyriacou, G., K. Tzoanas, and I. Poulios. "Photocatalytic Decomposition of 2,3-Dichloropyridine over Aqueous Suspensions of $\mathrm{TiO}_{2}$." J. Environ. Sci. Health, Part A: Environ. Sci. Eng. Toxic Hazard. Subst. Control A32(4) (1997): 963-977.

391. Lacoste, J., P. Ladsous, M. Dieppedale, and R. Arnaud. "Quantitative Study of Photocatalyzed Oxidation of Ethylene-Propylene Rubber and Atactic Polypropylene.” J. Appl. Polym. Sci. 69(9) (1998): 1681-1689.

392. Lakshmi, Brinda B., Peter K. Dorhout, and Charles R. Martin. "Sol-Gel Template Synthesis of Semiconductor Nanostructures." Chem. Mater. 9(3) (1997): 857-862.

393. Lakshmi, Brinda B. and Charles R. Martin. "Sol-Gel Template Synthesis of Semiconductor Nanostructures." Proc. Electrochem. Soc. 97-11, Quantum Confinement: Nanoscale Materials, Devices, and Systems (1997): 47-55.

394. Larson, Sheldon A. and John L. Falconer. "Initial Reaction Steps in Photocatalytic Oxidation of Aromatics." Catal. Lett. 44(1,2) (1997): 57-65.

395. Lau, Lisa D., Rene Rodriguez, Shannon Henery, David Manuel, and Lynn Schwendiman. "Photoreduction of Mercuric Salt Solutions at High PH." Environ. Sci. Technol. 32(5) (1998): 670675 .

396. Lea, Jimmy and Adesoji A. Adesina. "The Photooxidative Degradation of Sodium Dodecyl Sulfate in Aerated Aqueous $\mathrm{TiO}_{2}$ Suspension.” J. Photochem. Photobiol. A 118(2) (1998): 111-22.

397. Lee, J.D. Influence of Carbonate Salts on the Photocatalytic Dehydration of 2-Propanol. Ph.D. diss., Univ. of Virginia (1993).

398. Lee, S., K. Nishida, M. Otaki, and S. Ohgaki. "Photocatalytic Inactivation of Phage Q.Beta. by Immobilized Titanium Dioxide Mediated Photocatalyst." Water Sci. Technol. 35(11-12) HealthRelated Water Microbiology 1996 (1997): 101-106.

399. Lee, Seockheon, Miyako Nakamura, and Shinichiro Ohgaki. "Inactivation of Phage Q.Beta. by 254nm UV Light and Titanium Dioxide Photocatalyst.” J. Environ. Sci. Health, Part A: Toxic/ Hazard. Subst. Environ. Eng. A33(8) (1998): 1643-1655.

400. Lee, Soo-Keun, Daniel Mcstay, and Peter K.J. Robertson. "Application of Laser Radiation for the 
Treatment of Waste Materials Using a Photocatalyst.” Proc. SPIE-Int. Soc. Opt. Eng. 3272, Laser Techniques for Surface Science III (1998): 120-125.

401. Lee, Tai Kyu, Dong Hyung Kim, Myung Seok Jeon, and Kyung Nam Kim. "Photocatalytic Treatment of Real Wastewater with Pt-Doped ZnO and Pd-Doped ZnO." Oxid. Technol. Water Wastewater Treat., Int. Conf., ed. Alfons Vogelpohl, Paper no. 36, Clausthal-Zellerfield, Germany: Papierflieger Verlag (1996).

402. Lee, Wan In, Guang Jin Choi, and Young Rag Do. "Effect of $\mathrm{Au}$ and $\mathrm{WO}_{3}$ on the Surface Structure and Photocatalytic Activity of $\mathrm{TiO}_{2}$." Bull. Korean Chem. Soc. 18(6) (1997): 667-670.

403. Lepore, Giuseppe P., Lalchan Persaud, and Cooper H. Langford. "Supporting Titanium Dioxide Photocatalysts on Silica Gel and Hydrophobically Modified Silica Gel." J. Photochem. Photobiol. A 98(1-2) (1996): 103-111.

404. Levy, Boris. "Photocharge: A Technique for Determination of Light-Induced Charge Carrier Dynamics and Separation." IS\&T's Annu. Conf., Final Program Proc., 49th (23-4), Springfield, VA: IS\&T--The Society for Imaging Science and Technology (1996).

405. Levy, Boris. "Photochemistry of Nanostructured Materials for Energy Applications." J. Electroceram. 1(3) (1997): 239-272.

406. Levy, Boris and Mahmoud Sadeghi. "Optimization vs. Maximization of Photoinduced Charge Carrier Separation in Heterogeneous Photocatalysis and AgX Imaging." IS\&T's Annu. Conf., Final Program Proc., 49th (176-8), Springfield, VA: IS\&T--The Society for Imaging Science and Technology (1996).

407. Lewis, L.N. "Chemical Catalytis by Colloids and Clusters.” Chem. Rev. 93(8) (1993): 2693-2730.

408. Leyva, E., E. Moctezuma, M.G. Ruiz, and L. Torres-Martinez. "Photodegradation of Phenol and 4-Chlorophenol by $\mathrm{BaO}-\mathrm{Li}_{2} \mathrm{O}-\mathrm{TiO}_{2}$ Catalysts." Catal. Today 40(4) (1998): 367-376.

409. Li, Jilian, Xinyong Li, and Wenzhao Li. "Kinetics of Photocatalytic Oxidation Cyclohexane over Nano- $\mathrm{TiO}_{2}$ and Its Influencing Factors." Jiangxi Shifan Daxue Xuebao, Ziran Kexueban, 21(1) (1997): 72-74, 99.

410. Li, Lin and Po-Lock Yue. "Gas-Phase Photocatalytic Oxidation of $\mathrm{CHClCCl}_{2}$ and $\mathrm{PhMe}$ by Supported Titania." Cuihua Xuebao 17(5) (1996): 450-454.

411. Li Puma, Gianluca and Po Lock Yue. "A Laminar Falling Film Slurry Photocatalytic Reactor. Part II - Experimental Validation of the Model.” Chem. Eng. Sci. 53(16) (1998): 3007-3021.

412. Li, Tian and Zhengfu Chen. "Performance of the Immobile Membrane Photocatalytic Reactor for Main Water Purification.” Huanjing Kexue Xuebao 18(2) (1998): 167-171.

413. Li, Tian, Xushi Yan, and Weixing Huang. "Deep Purification of Main-Water by Using Fixed Membrane Photocatalytic Oxidation Reactor." Zhongguo Jishui Paishui, 12(3) (1996): 7-10.

414. Li, X. Z., M. Zhang, and H. Chua. "Disinfection of Municipal Wastewater by Sensitized Photooxidation." Water Sci. Technol. 33(3), High-Performance Low-Cost Environmental and Sanitation Control Systems (1996): 111-118. 
415. Li, X.Z. and Y.G. Zhao. On-Site Treatment of Dyeing Wastewater by a Bio-Photoreactor System." Water Sci. Technol. 36(2-3), Pretreatment of Industrial Wastewaters II (1997): 165-172.

416. Li, Yuexiang and F. Wasgestian. "Photocatalytic Reduction of Nitrate Ions on $\mathrm{TiO}_{2}$ by Oxalic Acid." J. Photochem. Photobiol. A 112(2,3) (1998): 255-259.

417. Lichtin, Norman N. and Mahmoud Sadeghi. "Oxidative Photocatalytic Degradation of Benzene Vapor over $\mathrm{TiO}_{2}$." J. Photochem. Photobiol. A 113(1) (1998): 81-88.

418. Lin, Jun and Jimmy C. Yu. "An Investigation on Photocatalytic Activities of Mixed $\mathrm{TiO}_{2}$-Rare Earth Oxides for the Oxidation of Acetone in Air." J. Photochem. Photobiol. A 116(1) (1998): 63-67.

419. Lin, Wen-Yuan, Norma R. de Tacconi, Russell L. Smith, and Krishnan Rajeshwar. "Manifestation of Photocatalysis Process Variables in a Titanium Dioxide-Based Slurry Photoelectrochemical Cell. J. Electrochem. Soc. 144(2) (1997): 497-502.

420. Lin, Wen-Yuan and Krishnan Rajeshwar. "Photocatalytic Removal of Nickel from Aqueous Solutions Using Ultraviolet-Irradiated $\mathrm{TiO}_{2}$." J. Electrochem. Soc. 144(8) (1997): 2751-2756.

421. Lindner, M., D.W. Bahnemann, B. Hirthe, and W.-D. Griebler. "Solar Water Detoxification: Novel $\mathrm{TiO}_{2}$ Powders as Highly Active Photocatalysts.” J. Sol. Energy Eng. 119(2) (1997): 120-125.

422. Lindner, Martin, Joern Theurich, and Detlef W. Bahnemann. "Photocatalytic Degradation of Organic Compounds. Accelerating the Process Efficiency." Water Sci. Technol. 35(4), Oxidation Technologies for Water and Wastewater Treatment (1997): 79-86.

423. Lindner, Martin, Jorn Theurich, and Detlef W. Bahnemann. "Photocatalytic Degradation of Organic Compounds: Accelerating the Process Efficiency." Oxid. Technol. Water Wastewater Treat., Int. Conf., ed. Alfons Vogelpohl, Paper no. 38, Clausthal-Zellerfield, Germany: Papierflieger Verlag (1996).

424. Ling, Zang, Ping Qu, Jincai Zhao, Tao Shen, and Hisao Hidaka. "Photocatalytic Bleaching of P-Nitrosodimethylaniline in $\mathrm{TiO}_{2}$ Aqueous Suspensions:. A Kinetic Treatment Involving Some Primary Events Photoinduced on the Particle Surface." J. Mol. Catal. A: Chem. 120(1-3) (1997): $235-245$.

425. Litter, M.I. and J.A. Navio. "Photocatalytic Properties of Iron-Doped Titania Semiconductors." J. Photochem. Photobiol. A 98(3) (1996): 171-181.

426. Liu, Chunyan. "Photographic Imaging and Heterogeneous Photocatalysis." Ganguang Kexue Yu Guang Huaxue 14(4) (1996): 365-373.

427. Liu, Hong, Shao'an Cheng, Qiquan Wang, Jianqing Zhang, and Weichuan Jiang. "Mechanism of Semiconductor Photocatalytic Degradation of Gaseous Trichloroethylene without Water." Huanjing Kexие 19(2) (1998): 62-65,70.

428. Liu, Hong, Shao'an Cheng, Jianqing Zhang, Chunan Cao, and Weichuan Jiang. "The GasPhotocatalytic Degradation of Trichloroethylene without Water." Chemosphere 35(12) (1997): 2881-2889. 
429. Liu, Hong, Shaoan Cheng, Jianqing Zhang, Chunan Cao, and Weichuan Jiang. "Study on the Semiconductor Photocatalytic Degradation of Gaseous Trichloroethylene without Water." Zhongguo Huanjing Kexue 18(2) (1998): 144-147.

430. Liu, Huwei, Ira S. Krull, Arlen Kaufman, Wayne O. Aruda, and Peter T. Kissinger. "A New PostColumn Photochemical Reactor for Liquid Chromatography." Curr. Sep. 16(2) (1997): 37-42.

431. Liu, Miao, Deming Dong, Baiyu Zhang, Jinming Yang, Chunhong Li, Minghong Tian, and Yan Li. "Treatment of Cr(VI) in Plating Wastewater With Photocatalysis." Jilin Daxue Ziran Kexue Xuebao 2 (1998): 99-101.

432. Liu, Shunlin and Tetsuo Saji. "Photocatalytic Formations of Patterning Dye Films with $\mathrm{TiO}_{2}$ Particles Based on Chromatic Development of Photography.” Bull. Chem. Soc. Jpn. 70(4) (1997): $755-60$.

433. Liu, Zhengbao and Qingzhao Yao. "Photocatalytic Oxidation and Its Development. Gongye Shuichuli 17(6) (1997): 7-8.

434. Lo, Shang-Lien, Chao-Yin Kuo, Ya-Wen Ko, Yu-Chun Chiang, and Paris Honglay Chen. "A Kinetics Study of Photocatalytic Oxidation with $\mathrm{TiO}_{2}$ to Remove DOC from Drinking Water." Zhongguo Huanjing Gongcheng Xuekan 6(4) (1996): 453-455.

435. Lobedank, J., E. Bellmann, and J. Bendig. "Sensitized Photocatalytic Oxidation of Herbicides Using Natural Sunlight." J. Photochem. Photobiol. A 108(1) (1997): 89-93.

436. Loddo, Vittorio, Giuseppe Marci, Leonardo Palmisano, and Antonino Sclafani. "Preparation and Characterization of $\mathrm{Al}_{2} \mathrm{O}_{3}$ Supported $\mathrm{TiO}_{2}$ Catalysts Employed for 4-Nitrophenol Photodegradation in Aqueous Medium." Mater. Chem. Phys. 53(3) (1998): 217-224.

437. Lopez, T., E. Sanchez, R. Gomez, L. Ioffe, and Y. Borodko. "Platinum Acetylacetonate Effect on Sol-Gel Derived Titania Catalysts.” React. Kinet. Catal. Lett. 61(2) (1997): 289-295.

438. Lowekamp, J.B., G.S. Rohrer, P.A. Morris Hotsenpiller, J.D. Bolt, and W.E. Farneth. “Aniso- tropic Photochemical Reactivity of Bulk $\mathrm{TiO}_{2}$ Crystals.” J. Phys. Chem. B 102(38) (1998): 7323-7327.

439. Luo, Yang and David F. Ollis. "Heterogeneous Photocatalytic Oxidation of Trichloroethylene and Toluene Mixtures in Air: Kinetic Promotion and Inhibition, Time-Dependent Catalyst Activity." J. Catal. 163(1) (1996): 1-11.

440. Ma, Ying and Jian-nian Yao. "Photodegradation of Rhodamine B Catalyzed by $\mathrm{TiO}_{2} \mathrm{Thin}$ Films." $J$. Photochem. Photobiol. A 116(2) (1998): 167-170.

441. Ma, Ying and Jiannian Yao. "Comparison of Photoreactions of Rhodamine B Catalyzed by a $\mathrm{TiO}_{2}$ Thin Film and a Degussa P-25 Coated Film.” Ganguang Kexue Yu Guang Huaxue 16(2) (1998): $117-121$.

442. Madden, Thomas H., Abhaya K. Datye, Melissa Fulton, Michael R. Prairie, Sabir A. Majumdar, and Bertha M. Stange. "Oxidation of Metal-EDTA Complexes by $\mathrm{TiO}_{2}$ Photocatalysis." Environ. Sci. Technol. 31(12) (1997): 3475-3481. 
443. Madden, Thomas H., Abhaya K. Datye, Michael R. Prairie, and Bertha M. Stange. "Evaluation of the Treatment of Metal-EDTA Complexes Using $\mathrm{TiO}_{2}$ Photocatalysis." Solar Engineering 1996, eds. Jane H. Davidson and James Chavez, New York, NY: ASME (1996): 71-78.

444. Maeda, Hiroyuki, Katsuyoshi Ikeda, Akira Fujishima, Kazuhito Hashimoto, Katsuhiro Ajito, and Masao Morita. "Microscopic Observation of $\mathrm{TiO}_{2}$ Photocatalysis Using Scanning Electrochemical Microscopy." Proc. Electrochem. Soc., 98-5, Environmental Issues in the Electronics/ Semiconductor Industries and Electrochemical/Photochemical Methods for Pollution Abatement (1998): 129-136.

445. Maezawa, Akinori and Shigeo Uchida. "Wastewater Treatment by Photooxidation." Kino Zairyo 18(7) (1998): 25-32.

446. Magrini, K.A., R. Rabago, S.A. Larson, and C.S. Turchi. "Control of Gaseous Solvent Emissions Using Photocatalytic Oxidation." Proc., Annu. Meet. Air Waste Mgmt. Assoc., 89th (1996): fa14605/1-fa14605/8.

447. Magrini, Kimberly A., Rita M. Goggin, Andrew S. Watt, and Michael Taylor. "Water Composition Effects on the Photocatalytic Decomposition of Aqueous Trichloroethylene." Solar Engineering 1992, New York, NY: ASME (1992).

448. Magrini, Kimberly A. and John D. Webb. "Photocatalytic Decomposition of Aqueous Organic Compounds as a Function of Solar Irradiation Intensity." 1990 ASME International Solar Energy Conference, eds. J. Taylor Beard and M.A. Ebadian, New York, NY: ASME (1990): 159-162.

449. Magrini, Kimberly A., John D. Webb, Rita M. Goggin, and Derende M. Coover. "Photocatalytic Trichloroethylene Decompostion: Preliminary Results of Irradiation Intensity Effects." IECEC-89, 24th Intersociety Energy Conversion Engineering Conference (1989).

450. Majumder, Sabir A., Michael R. Prairie, John A. Shelnutt, Gail N. Ryba, James E. Miller, Terry J. Garino, and Shahed U.M. Khan. Engineered Photocatalysts for Detoxification of Waste Water, SAND96-2925 UC-1303. Sandia National Laboratory, Albuquerque, NM (1996).

451. Majunder, Sabir A., Michael R. Prairie, Mark R. Ondrias, and John A. Shelnutt. "Enhancement of Solar Photocatalytic Detoxification by Adsorption of Porphyrins onto $\mathrm{TiO}_{2}$." Solar Engineering 1992, eds. William Stine, Jan Kreider, and Koichi Watanabe, New York, NY: ASME (1992): 9-14.

452. Malato, S. and J. Blanco. "Influence of $\mathrm{TiO}_{2}$ and UV Radiation over Pentachlorophenol Degradation with Solar Radiation." 7th Intl. Symp. on Solar Thermal Concentrating Technol., eds. O. Popel, S. Fris, and E. Shchedrova, Moscow, Russia: Institute for High Temperature of Russian Academy of Science (1994): 540-550.

453. Malato, S., J. Blanco, C. Richter, D. Curco, and J. Gimenez. "Low-Concentrating CPC Collectors for Photocatalytic Water Detoxification. Comparison with a Medium Concentrating Solar Collector." Oxid. Technol. Water Wastewater Treat., Int. Conf., ed. Alfons Vogelpohl, Paper no. 35, ClausthalZellerfield, Germany: Papierflieger Verlag (1996).

454. Malato, S., J. Blanco, C. Richter, D. Curco, and J. Gimenez. "Low-Concentrating CPC Collectors for Photocatalytic Water Detoxification: Comparison with a Medium Concentrating Solar Collector." Water Sci. Technol. 35(4), Oxidation Technologies for Water and Wastewater Treatment (1997): 157-164. 
455. Malato, S., J. Blanco, C. Richter, and I. Maldonado. "Procesos Fotoquimicos para la Descontaminacion de Aguas: La Fotocatallisis Solar y Su Aplicacion. Tratamiento del Agua de Lavado de Envases de Fitosanitarios en la Provincia de Almeria." IV Simposio Sobre el Agua en Andalucia, Instituto Tecnoligico Geominero de Espana (1996): 341-350

456. Malato, S., J. Blanco, C. Richter, and M. Vincent. "Photocatalytic Degradation of Industrial Residual Waters.” Solar Energy 56(5) (1996): 401-410.

457. Malone, John P. and R. James Stevens. "Removal of Nitrite Impurity from Nitrate Labeled with Nitrogen-15.” Soil Sci. Soc. Am. J. 62(3) (1998): 651-653.

458. Mandelbaum, Pablo A., Alberto E. Regazzoni, Miguel A. Blesa, and Sara A. Bilmes. "Mechanism of Methanol Photoelectrooxidation on Titanium Dioxide Thin Film Electrodes." Proc. Electrochem. Soc. 97-20 Photoelectrochemistry (1997): 88-96.

459. Maness, Pin-Ching, Sharon L. Smolinski, Daniel M. Blake, Zheng Huang, Edward J. Wolfrum, and William A. Jacoby. "Bactericidal Activity of Photocatalytic $\mathrm{TiO}_{2}$ Reaction: An Understanding toward Its Killing Mechanism.” Appl. Environ. Microbiol. (1999): In Press.

460. Mansilla, Hector D., M. Cristina Yeber, Juanita Freer, Jaime Rodriguez, and Jaime Baeza. "Homogeneous and Heterogeneous Advanced Oxidation of a Bleaching Effluent from the Pulp and Paper Industry." Oxid. Technol. Water Wastewater Treat., Int. Conf., ed. Alfons Vogelpohl, Paper no. 42, Clausthal-Zellerfield, Germany: Papierflieger Verlag (1996).

461. Mansilla, Hector D., M. Cristina Yeber, Juanita Freer, Jaime Rodriguez, and Jaime Baeza. "Homogeneous and Heterogeneous Advanced Oxidation of a Bleaching Effluent from the Pulp and Paper Industry." Water Sci. Technol. 35(4), Oxidation Technologies for Water and Wastewater Treatment (1997): 273-278.

462. Marques, P.A.S.S., M.F. Rosa, F. Mendes, M. Collares Pereira, J. Blanco, and S. Malato. "Wastewater Detoxification of Organic and Inorganic Toxic Compounds with Solar Collectors." Desalination 108(1-3) (1997): 213-220.

463. Martin, C., G. Solana, V. Rives, G. Marci, L. Palmisano, and A. Sclafani. "Physicochemical Properties of $\mathrm{WO}_{3} / \mathrm{TiO}_{2}$ Systems Employed for 4-Nitrophenol Photodegradation in Aqueous Medium." Catal. Lett. 49(3-4) (1998): 235-243.

464. Martin, Randal S., Clinton P. Richardson, Tianguang Fan, and Charles P. VI Halbert. "Control of Gas-Phase Chlorobenzene Using $\mathrm{TiO}_{2}$-Mediated Photocatalysis and Packed-Bed Absorption." Proc. Annu. Meet. Air Waste Mgmt. Assoc., 91st (1998): TPB04P-1-TPB04P/16.

465. Martin, Scot Turnbull. Photocatalyzed Destruction of Chlorinated Hydrocarbons (Titanium Dioxide, Zinc Oxide, Vanadium Oxide). Ph.D. diss., California Institute of Technology (1996).

466. Mas, D., P. Pichat, and C. Guillard. "Intermediate Products and Reductive Reaction Pathways in the $\mathrm{TiO}_{2}$ Photocatalytic Degradation of 1,1,1-Trichloroethane in Water." Res. Chem. Intermed. 23(3) (1997): 275-290.

467. Mas, Denis, Herve Delprat, and Pierre Pichat. " $\mathrm{TiO}_{2}$ Photocatalysis for Destruction of Trace $\mathrm{CCl}_{3} \mathrm{CH}_{3}, \mathrm{CFCl}_{2} \mathrm{CH}_{3}$ and $\mathrm{CF}_{3} \mathrm{CH}_{2} \mathrm{~F}$ in Water." Proc. Electrochem. Soc. 97-20 Photoelectrochemistry (1997): 289-300. 
468. Matos, Juan, Jorge Laine, and Jean-Marie Herrmann. "Synergy Effect in the Photocatalytic Degradation of Phenol on a Suspended Mixture of Titania and Activated Carbon." Appl. Catal. B 18(3-4) (1998): 281-91.

469. Matsui, Hiroshi, Susumu Kawai, Hideki Yoshioka, Tsuguo Ishihara, Makoto Akamatsu, and Muneyuki Motoyama. "Creation of New Life Style by Environmental Ceramics." Hyogo-Kenritsu Kogyo Gijutsu Senta Kenkyu Hokokusho 7 (1997): 48.

470. Matsumoto, Yasumichi, Chiyuki Nakanishi, Yoshie Ishikawa, Michio Koinuma, and Nobumitsu Yatsushiro. "Photocatalytic Activity of Electrochemically Fixed $\mathrm{TiO}_{2}$ on Alumite." Hyomen Gijutsu 48(12) (1997): 1225-1226.

471. Matsunaga, T. "Sterilization with Particulate Photosemiconductor." J. Antibact. Antifungic. Agents 13(5) (1985): 211-220.

472. Matsushita, Sachiko, Tetsuya Miwa, and Akira Fujishima. "Preparation of a New Nanostructured $\mathrm{TiO}_{2}$ Surface Using a Two-Dimensional Array-Based Template." Chem. Lett. 9 (1997): 925-926.

473. Matsushita, Sachiko I., Tetsuya Miwa, Donald A. Tryk, and Akira Fujishima. "New Mesostructured Porous $\mathrm{TiO}_{2}$ Surface Prepared Using a Two-Dimensional Array-Based Template of Silica Particles." Langmuir 14(22) (1998): 6441-6447.

474. Matthews, Lowell R., David Avnir, Alexander D. Modestov, Srinivasan Sampath, and Ovadia Lev. "The Incorporation of Titania into Modified Silicates for Solar Photodegradation of Aqueous Species.” J. Sol-Gel Sci. Technol. 8(1-3) (1997): 619-623.

475. Maurino, C. Minero and E. Pelizzetti. "Heterogeneous Photocatalytic Transformations of S-Triazine Derivatives." Res. Chem. Intermed. 23(4) (1997): 291-310.

476. Maurino, V., C. Minero, E. Pelizzetti, P. Piccinini, N. Serpone, and H. Hidaka. "The Fate of Organic Nitrogen under Photocatalytic Conditions: Degradation of Nitrophenols and Aminophenols on Irradiated $\mathrm{TiO}_{2} . "$ J. Photochem. Photobiol. A 109(2) (1997): 171-176.

477. May, E. Kenneth. Development of Teflon-Based Reflective Film for Solar Concentrators. Final Report: National Renewable Energy Laboratory Subcontract No. AAR-4-14019-01, Solar Industrial Technology, Golden, CO (1996).

478. May, E. Kenneth, Randy Gee, David T. Wickham, Laura A. Lafloon, and John D. Wright. Design and Fabrication of Prototype Solar Receiver/Reactors for the Solar Detoxification of Contaminated Water, Industrial Solar Technology Corporation, Golden, Colorado (1991).

479. Mazurkevich, Ya. S. and I.M. Kobasa. "Photosensitive Dielectric Materials Based on $\mathrm{TiO}_{2}$ and $\mathrm{SiO}_{2}$ $\mathrm{TiO}_{2}$. . Inorg. Mater. (Transl. of Neorg. Mater.) 33(12) (1997): 1258-1260.

480. Mazurkevich, Ya. S., I.M. Kobasa, and N.I. Zozulya. "Effect of the Composition of Activation Solution and Complexation on the Quality of Photoselective Metalization of Dielectrics." Izv. Vyssh. Uchebn. Zaved., Khim. Khim. Tekhnol. 40(6) (1997): 79-83.

481. Mazurkevich, Ya. S., N.I. Zozulya, and I.M. Kobasa. "Novel Photosensitive Dielectric Materials and Wasteless Technologies for Their Metalization." Izv. Vyssh. Uchebn. Zaved., Khim. Khim. Tekhnol. 41(1) (1998): 98-101. 
482. Mazzarino, I., P. Piccinini, and G. Capriati. "Oxidation of Refractory Organic Pollutants in a Continuous Photocatalytic Reactor with a Fixed Supported Catalyst." Water Pollut. IV: Modell., Meas. Predict., Int. Conf., 4th, eds. R. Rajar, and C.A. Brebbia, Southampton, UK: Computational Mechanics Publications (1997): 701-709.

483. Mehos, M.S., Kimberly A. Pacheco, and Hal F. Link. "Measurement and Analysis of Near Ultraviolet Solar Radiation.” ASME International Solar Energy Conference, eds. William B. Stine, Jan Kreider, and Koichi Watanabe, New York, NY: ASME (1992) 51-55.

484. Mendez-Roman, Rafael, and Nelson Cardona-Martinez. "Relationship between the Formation of Surface Species and Catalyst Deactivation during the Gas-Phase Photocatalytic Oxidation of Toluene." Catal. Today 40(4) (1998): 353-365.

485. Meunier, Berhard and Alexander Sorokin. "Oxidation of Pollutants Catalyzed by Metallophthalocyanines.” Acc. Chem. Res. 30(11) (1997): 470-476.

486. Micic, O.I., A.E. Ostafin, T. Rajh, J.J. Sabelko, M.C. Thurnauer, D.M. Tiede, and Y. Zhang. "Conversion of Holes into Reducing Species on Surface Modified Small-Particle $\mathrm{TiO}_{2}$." Chem. Oxid. (1997): 5303-5313.

487. Miki, Takeshi and Hisao Yanagi. "Scanning Probe Microscopic Characterization of SurfaceModified N-TiO 2 Single-Crystal Electrodes." Langmuir 14(12) (1998): 3405-3410.

488. Miller, Matthew L., John Borisch, Daniel Raftery, and Joseph S. Francisco. "Changing the Product State Distribution and Kinetics in Photocatalytic Surface Reactions Using Pulsed Laser Irradiation." J. Am. Chem. Soc. 120(32) (1998): 8265-8266.

489. Mills, Andrew, Ahmed Belghazi, and Derek Rodman. "Bromate Removal from Drinking Water by Semiconductor Photocatalysis." Water Res. 30(9) (1996): 1973-1978.

490. Mills, Andrew and Stephen Le Hunte. "An Overview of Semiconductor Photocatalysis." J. Photochem. Photobiol. A 108(1) (1997): 1-35.

491. Milne, Tom and Mark Nimlos. "Incomplete Photocatalytic Oxidation of TCE." Chem. Eng. News 70(25) (1992): 2.

492. Milosavljevic, Emil B., Ljiljana Solujic, W. Scott Rader, and James L. Hendrix. "Sunlight Induced Photo-Catalytic Decontamination of Cyanide Containing Wastes." Pollut. Prev. Process Eng., Proc. Tech. Solutions Pollut. Prev. Min. Miner. Process. Ind., Eng. Found. Conf., eds. Paul E. Richardson and Bernard J. Scheiner, New York, NY: Engineering Foundation (1996): 165-74.

493. Minero, C., V. Maurino, P. Calza, and E. Pelizzetti. "Photocatalytic Formation of Tetrachloromethane from Chloroform and Chloride Ions." New J. Chem. 21(6-7) (1997): 841-842.

494. Minero, C., V. Maurino, and E. Pelizzetti. "Photocatalytic Transformations of Hydrocarbons at the Sea Water/Air Interface under Solar Radiation.” Mar. Chem. 58(3-4) (1997): 361-372.

495. Minero, Claudio, Paola Piccinini, Paola Calza, and Ezio Pelizzetti. "Photocatalytic Reduction/ Oxidation Processes Occurring at the Carbon and Nitrogen of Tetranitromethane." New J. Chem. 20(11) (1996): 1159-1164. 
496. Mita, Keisuke, Masakazu Tada, Shunichi Kizuki, and Takeshi Hoshikawa. "Photocatalytic Reactions on $\mathrm{TiO}_{2}$ in Boiling Solution." Kagaku to Kogyo 72(3) (1998): 100-104.

497. Miyashita, Kiyoshi, Tatsuki Ozawa, Yoshikazu Ooyama, and Hideki Maru. "Measurements of $\mathrm{TiO}_{2}$ Photocatalysis Effect Evaluated by X-Ray Photoelectron Spectroscopy." Gunma-Ken Kogyo Shikenjo Kenkyu Hokoku 1995 (1996): 1-3.

498. Modestov, A.D. and O. Lev. "Photocatalytic Oxidation of 2,4-Dichlorophenoxyacetic Acid with Titania Photocatalyst. Comparison of Supported and Suspended $\mathrm{TiO}_{2}$." J. Photochem. Photobiol. A 112(2-3) (1998): 261-70.

499. Modestov, Alexander, Victor Glezer, Iliya Marjasin, and Ovadia Lev. "Photocatalytic Degradation of Chlorinated Phenoxyacetic Acids by a New Buoyant Titania-Exfoliated Graphite Composite Photocatalyst." J. Phys. Chem. B 101(23) (1997): 4623-4629.

500. Mohs, Cathy Rene. Nanoscale Particles of Magnesium Oxide and (Iron(III)Oxide)Magnesium Oxide as Destructive Adsorbents and Titanium Dioxide as a Photodegradation Catalyst for Environmentally Hazardous Materials. Ph.D. diss., Kansas State Univ. (1996).

501. Morelli, Roberto, Ignazio Renato Bellobono, Claudia Maria Chiodaroli, and Sergio Alborghetti. "EPR Spin-Trapping of Hydroxyl Radicals onto Photocatalytic Membranes Immobilizing Titanium Dioxide, and Spin Adduct Competition, as a Probe of Reactivity with Aqueous Organic Micropollutants." J. Photochem. Photobiol. A 112(2-3) (1998): 271-276.

502. Morioka, T., T. Saito, Y. Nara, and K. Onoda. "Antibacterial Action of Powdered Semiconductor on Serotype g Streptococcus Mutans." Caries Res. 22 (1988): 230-231.

503. Moriya, Takashi, Tatsushi Matsuyama, and Hideo Yamamoto. "Formation of Titania Fine Particle Layer by Hybrid Process of SPCP-CVD and EFCM for Photocatalytic Reactor." World Congr. Part. Technol. 3, Rugby, UK.: Institution of Chemical Engineers (1998): 1684-1692.

504. Muggli, Darrin S. and John L. Falconer. "Catalyst Design to Change Selectivity of Photocatalytic Oxidation.” J. Catal. 175(2) (1998): 213-219.

505. Muggli, Darrin S., Sheldon A. Larson, and John L. Falconer. "Photocatalytic Oxidation of Ethanol: Isotopic Labeling and Transient Reaction." J. Phys. Chem. 100(39) (1996): 15886-15889.

506. Muggli, Darrin S., Justin T. McCue, and John L. Falconer. "Mechanism of the Photocatalytic Oxidation of Ethanol on $\mathrm{TiO}_{2} . "$ J. Catal. 173(2) (1998): 470-483.

507. Muneer, M., R. Philip, and S. Das. "Photocatalytic Degradation of Wastewater Pollutants Titanium Dioxide-Mediated Oxidation of a Textile Dye, Acid Blue 40." Res. Chem. Intermed. 23(3) (1997): 233-246.

508. Muneer, M., J. Theurich, and D. Bahnemann. "Titanium Dioxide Mediated Photocatalytic Degradation of Two Major Organic Pollutants: 1,2-Diethyl Phthalate and Diuron.” Proc. Electrochem. Soc. 98-5, Environmental Issues in the Electronics/Semiconductor Industries and Electrochemical/Photochemical Methods for Pollution Abatement (1998): 174-187. 
509. Munroe, N.D.H. and R. Tilleux. "Rate Enhancement of Photocatalytic Cyanide Oxidation by the Application of an Anodic Bias/Coupled Semiconductor Configuration." Proc. Int. Top. Meet. Nucl. Hazard. Waste Mgmt., SPECTRUM '96, 6th, La Grange Park, IL: American Nuclear Society (1996): 425-429.

510. Murabayashi, Masayuki, Kiminori Itoh, and Kunihiro Togashi. "Photocatalytic Degradation of Trichloroethylene in Liquid Phase and in Gas Phase by Using Titanium Dioxide with Platinum Deposition.” Denki Kagaku Oyobi Kogyo Butsuri Kagaku 66(6) (1998): 671-672.

511. Muradoc, Nazim Z., Ali T. Raissi, Sivakumar Jaganathan, and Charles R. Painter. "PGA and FTIR Study of Nitroglycerin Photodecomposition on Titania Surface." Proc. Annu. Meet. Air Waste Mgmt. Assoc., 88th, 4B (1995): 95-TP60P.05.

512. Muradov, Nazim Z., Ali T-Raissi, Sivakumar Jaganathan, and Charles R. Painter. "Characterization of $\mathrm{TiO}_{2}$ Immobilized Films for Photocatalytic Decomposition of NG." Chem. Oxid. 1995 (1997): 5325-5334.

513. Murakata, Tadahiro, Ryoich Yamamoto, Yuichi Yoshida, Masanobu Hinohara, Tateaki Ogata, and Shimio Sato. "Preparation of Ultrafine $\mathrm{TiO}_{2}$ Particles Dispersible in Organic Solvents and Their Photocatalytic Properties.” J. Chem. Eng. Jpn. 31(1) (1998): 21-28.

514. Murasawa, Sadao. "Titanium Dioxide Photocatalyst and Recent Applications." Shikizai Kyokaishi 69(7) (1996): 444-454.

515. Murata, Yoshihiko, Kiyoshi Kamitani, Hideo Tawara, and Koji Takeuchi. "Air Purifying Pavement. Development of Photocatalytic Concrete Blocks for Removal of NOx." Shigen to Sozai 114(5) (1998): 381-386.

516. Nahen, Michael, Detlef Bahnemann, Ralf Dillert, and Gregor Fels. "Photocatalytic Degradation of Trinitrotoluene: Reductive and Oxidative Pathways." J. Photochem. Photobiol. A 110(2) (1997): 191-199.

517. Nakaoka, Yasuhiro and Yoshio Nosaka. "ESR Investigation into the Effects of Heat Treatment and Crystal Structure on Radicals Produced over Irradiated $\mathrm{TiO}_{2}$ Powder." J. Photochem. Photobiol. A 110(3) (1997): 299-305.

518. Nakatsuji, Tadao. “Titanium Oxide Photocatalyst Materials, SSP Series.” Kogyo Zairyo 45(10) (1997): 45-47.

519. Nameki, Hirofumi, Koji Hoshi, Masayoshi Fukazawa, and Toru Kuno. "Development of Ceramics for Removing Pollutants from Environment (Part III) -- Preparation of $\mathrm{TiO}_{2}$ Photocatalyst Thin Films Using Film-Forming Organic Agent.” Aichi-Ken Tokoname Yogyo Gijutsu Senta Hokoku 24 (1997): $1-4$.

520. Nameki, Horofumi, Koji Hoshi, Masayoshi Fukazawa, and Toru Kuno. "Development of Ceramics for Removing Pollutants from Environment (Part IV)—Effect of Additive of Poly(Ethylene Glycol) to Film-Forming Organic Agent on Photocatalytic Function of Prepared $\mathrm{TiO}_{2}$ Thin Films." AichiKen Tokoname Yogyo Gijutsu Senta Hokoku 24 (1997): 5-8.

521. Namiki, N., Y. Otani, H. Emil, N. Ohigashi, F. Yoshikawa, S. Hayakawa, and M. Ukaji. "Removal of Organic Gas Species by UV-Irradiated Titania Honeycombs." Proc. Inst. Environ. Sci. Technol. (1998), 44th (Contamination Control) (1998): 482-88. 
522. Naskar, Subrata, S. Arumugom Pillay, and Manas Chanda. "Photocatalytic Degradation of Organic Dyes in Aqueous Solution with $\mathrm{TiO}_{2}$ Nanoparticles Immobilized on Foamed Polyethylene Sheet." $J$. Photochem. Photobiol. A 113(3) (1998): 257-264.

523. Nasr, C., K. Vinodgopal, S. Hotchandani, A.K. Chattopadhyay, and P.V. Kamat. "Photocatalytic Reduction of Azo Dyes Naphthol Blue Black and Disperse Blue 79." Res. Chem. Intermed. 23(3) (1997): 219-231.

524. Navio, J.A., C. Cerrillos, M.A. Pradera, E. Morales, and J.L. Gomez-Ariza. "Photoassisted Degradation (in the UV) of Phenyltin(IV) Chlorides in the Presence of Titanium Dioxide." Langmuir 14(2) (1998): 388-395.

525. Navio, J.A., G. Colon, and J.M. Herrmann. "Photoconductive and Photocatalytic Properties of $\mathrm{ZrTiO}_{4}$. Comparison with the Parent Oxides $\mathrm{TiO}_{2}$ and $\mathrm{ZrO}_{2}$." J. Photochem. Photobiol. A 108(2-3) (1997): 179-85.

526. Navio, Jose A., Gerardo Colon, Maria Trillas, Jose Peral, Xavier Domenech, Juan J. Testa, Javier Padron, Diana Rodriguez, and Marta I. Litter. "Heterogeneous Photocatalytic Reactions of Nitrite Oxidation and Cr(VI) Reduction on Iron-Doped Titania Prepared by the Wet Impregnation Method." Appl. Catal. B 16(2) (1998): 187-196.

527. Nedeljkovic, J.M., N.M. Dimitrijevic, M.I. Comor, Z.V. Saponjic, and D.P. Uskokovic. "Nanocomposite Materials Prepared by Using Quantum Dots as Building Blocks." Mater. Sci. Forum 282-283, Advanced Materials and Processes (1998): 19-26.

528. Negishi, Nobuaki, Koji Takeuchi, and Takashi Ibusuki. "The Surface Structure of Titanium Dioxide Thin Film Photocatalyst.” Appl. Surf. Sci. 121-122 (1997): 417-420.

529. Neppolian, B., S. Sakthivel, Banumathi Arabindoo, M. Palanichamy, and V. Murugesan. "Photocatalytic Degradation of Textile Dye Commonly Used in Cotton Fabrics." Stud. Surf. Sci. Catal. 113, Recent Advances in Basic and Applied Aspects of Industrial Catalysis (1998): 329-335.

530. Ngame, S., T. Oku, M. Kambara, and K. Konishi. "Antimicrobial Effect of the Powdered Semiconductor $\mathrm{TiO}_{2}$ on the Viability of Oral Micro-Organisms.” J. Dent. Res. 68 (1989): 16961697.

531. Nico, Jill A., Suneetha Annangi, Rajnish Changrani, Rao Annapragada, and Gregory B. Raupp. "Modeling Light Distribution in a Heterogeneous Packed Bed Photocatalytic Oxidation Reactor." Proc. Annu. Meet. Air Waste Mgmt. Assoc., 89th (1996): fa14601/1-fa14601/15.

532. Nicolella, Cristiano and Mauro Rovatti. "Mathematical Modeling of Monolith Reactors for Photocatalytic Oxidation of Air Contaminants." Chem. Eng. J. 69(2) (1998): 119-126.

533. Nilsson, T., L. Montanarella, D. Baglio, R. Tilio, G. Bidoglio, and S. Facchetti. "Analysis of Volatile Organic Compounds in Environmental Water Samples and Soil Gas by Solid-Phase Microextraction." Int. J. Environ. Anal. Chem. 69(3) (1998): 217-226.

534. Nishikata, Satoshi. “Apparatus for Removal of Low Concentration Nitrogen Oxides.” Kogyo Zairyo 45(10) (1997): 86-88. 
535. Nivens, Delana A., Maria V. Schiza, and S. Michael Angel. "Multilayer Fiber-Optic Chemical Sensors Employing Organically Modified $\mathrm{SiO}_{2}$ and Mixed $\mathrm{TiO}_{2} / \mathrm{SiO}_{2}$ Sol-Gel Membranes." Proc. SPIE-Int. Soc. Opt. Eng. 3105, Chemical, Biochemical, and Environmental Fiber Sensors IX (1997): $52-60$.

536. Noda, Hiroyuki, Kazuo Oikawa, and Hitoshi Kamada. "ESR Spin-Trapping Study of Active Oxygen Radicals from Photoexcited Semiconductors in Aqueous $\mathrm{H}_{2} \mathrm{O}_{2}$ Solutions.” Bull. Chem. Soc. Jpn. 66 (1993): 455-458.

537. Noguchi, Tetsuro, Akira Fujishima, Phillip Sawunyama, and Kazuhito Hashimoto. "Photo- catalytic Degradation of Gaseous Formaldehyde Using $\mathrm{TiO}_{2}$ Film.” Environ. Sci. Technol. 32(23) (1998): 3831-3833.

538. Nogueira, Raquel F.P., Rosana M. Alberici, and Wilson F. Jardim. "Photodegradation of Wastewaters in the Presence of $\mathrm{TiO}_{2}$ and Fenton's Reagent." Chem. Oxid. 1996 (1997): 6221-6230.

539. Nogueira, Raquel F.P. and Wilson F. Jardim. "Heterogeneous Photocatalysis and Its Environ- mental Applications." Quim. Nova 21(1) (1998): 69-72.

540. Nohara, Kayo and Hisao Hidaka. "Environmental Photocatalysis." Hyomen 34(8) (1996): 441-448.

541. Nohara, Kayo, Hisao Hidaka, Ezio Pelizzetti, and Nick Serpone. "Processes of Formation of $\mathrm{NH}_{4}^{+}$ and $\mathrm{NO}_{3}{ }^{-}$Ions during the Photocatalyzed Oxidation of N-Containing Compounds at the Titania/Water Interface.” J. Photochem. Photobiol. A 102(2-3) (1997): 265-272.

542. Nonami, Toru. “Granular Photocatalysts Using Porous Silica Gel.” Kagaku Sochi 40(7) (1998): 5861.

543. Nosaka, Yoshio, Mitsuo Kishimoto, and Junichi Nishino. "Factors Governing the Initial Process of $\mathrm{TiO}_{2}$ Photocatalysis Studied by Means of In-Situ Electron Spin Resonance Measurements." J. Phys. Chem. B 102(50) (1998): 10279-10283.

544. Nosovich, A.A., N.M. Soboleva, and V.V. Goncharuk. "Photodestructive Oxidation of Cetylpyridinium Bromide in Water.” Khim. Tekhnol. Vody 17(5) (1995): 451-56.

545. O’Neill, Tim, Peter Strickler, and Rick Burke. Design and Fabrication of Prototype Solar Receiver/Reactors for the National Renewable Energy Laboratory, Measurement Technology Northwest, Seattle, WA (1992).

546. O’Shea, Kevin E., Shawn Beightol, Ivelitza Garcia, Martha Aguilar, David V. Kalen, and William J. Cooper. "Photocatalytic Decomposition of Organophosphonates in Irradiated $\mathrm{TiO}_{2}$ Suspensions." $J$. Photochem. Photobiol. A 107(1-3) (1997): 221-226.

547. Obee, Timothy N. "Photooxidation of Sub-Parts-Per-Million Toluene and Formaldehyde Levels on Titania Using a Glass-Plate Reactor.” Environ. Sci. Technol. 30(12) (1996): 3578-3584.

548. Obee, Timothy N. and Steve O. Hay. "Effects of Moisture and Temperature on the Photooxida- tion of Ethylene on Titania.” Environ. Sci. Technol. 31(7) (1997): 2034-2038. 
549. Ogawa, Shinichi and Yoshikazu Sakai. "Use of Light-Leakage-Type Glass Fiber for Photo- catalyst Filter.” Kogyo Zairyo 46(5) (1998): 118-121.

550. Ogawa, T., T. Saito, S. Ohno, T. Yasunaga, Y. Kitagawa, Y. Itoh, K. Ajito, T. Minabe, K. Hashimoto, and A. Fujishima. "Surface Treatment for Photocatalytic Interior-Finishing Materials I. Effects and Evaluation Method of Photocatalytic Activity of $\mathrm{TiO}_{2}$ Coating." Titanium '95: Sci. Technol., Proc. World Conf., 8th, eds. P.A. Blenkinsop, W.J. Evans, and H.M. Flower, London, UK: Institute of Materials (1996): 2089-2095.

551. Ogawara, K., S. Sugiuchi, S. Obori, A. Iso, Y. Suzuki, and M. Matsumato. "Earth Friendly Environmental Policy - Photocatalysis of Surfactants in Water (II).” Shiken Kenkyu Hokoku, Fukushima-Ken Haiteku Puraza 1995 (1996): 46-49.

552. Ohko, Yoshihisa, Akira Fujishima, and Kazuhito Hashimoto. "Kinetic Analysis of the Photocatalytic Degradation of Gas-Phase 2-Propanol Under Mass Transport Limited Conditions with a $\mathrm{TiO}_{2}$ Film Photocatalyst." J. Phys. Chem. B 102(10) (1998): 1724-1729.

553. Ohko, Yoshihisa, Kazuhito Hashimoto, and Akira Fujishima. "Kinetics of Photocatalytic Reactions under Extremely Low-Intensity UV Illumination on Titanium Dioxide Thin Films." J. Phys. Chem. A 101(43) (1997): 8057-8062.

554. Ohko, Yoshihisa, Donald A. Tryk, Kazuhito Hashimoto, and Akira Fujishima. "Autoxidation of Acetaldehyde Initiated by $\mathrm{TiO}_{2}$ Photocatalysis under Weak UV Illumination." J. Phys. Chem. B 102(15) (1998): 2699-2704.

555. Ohno, Teruhisa, Daisuke Haga, Kan Fujihara, Kaoru Kaizaki, and Michio Matsumura. "Unique Effects of Iron(III) Ions on Photocatalytic and Photoelectrochemical Properties of Titanium Dioxide." J. Phys. Chem. B 101(33) (1997): 6415-6419.

556. Ohno, Teruhisa, Daisuke Haga, Kan Fujihara, Kaoru Kaizaki, and Michio Matsumura. "Unique Effects of Iron(III) Ions on Photocatalytic and Photoelectrochemical Properties of Titanium Dioxide. [Erratum to Document Cited in CA127:168891].” J. Phys. Chem. B 101(49) (1997): 10605.

557. Ohno, Teruhisa, Takayo Kigoshi, Keizo Nakabeya, and Michio Matsumura. "Stereospecific Epoxidation of 2-Hexene with Molecular Oxygen on Photoirradiated Titanium Dioxide Powder." Chem. Lett. 9 (1998): 877-878.

558. Ohno, Teruhisa, Keizo Nakabeya, and Michio Matsumura. "Epoxidation of Olefins on Photoirradiated Titaniumdioxide Powder Using Molecular Oxygen as an Oxidant." J. Catal. 176(1) (1998): 76-81.

559. Ohshima, Kenji and Takeshi Nagai. "Titanium Oxide Photocatalyst Materials, DN Series." Kogyo Zairyo 45(10) (1997): 56-58.

560. Ohtani, Bunsho. "Reaction Selectivity Control in Electron Transfer Processes on Photo- irradiated Semiconductor Surfaces." New Challenges Org. Electrochem., ed. Tetsuo Osa, Amsterdam, Neth.: Gordon \& Breach (1998): 55-71.

561. Ohtani, Bunsho, Robert M. Bowman, D. Philip Jr. Colombo, Hiroshi Kominami, Hidenori Noguchi, and Kohei Uosaki. "Femtosecond Diffuse Reflectance Spectroscopy of Aqueous Titanium(IV) Oxide Suspension: Correlation of Electron-Hole Recombination Kinetics with Photocatalytic Activity." Chem. Lett. 7 (1998): 579-580. 
562. Ohtani, Bunsho, Yoshimasa Ogawa, and Sei-ichi Nishimoto. "Photocatalytic Activity of Amorphous-Anatase Mixture of Titanium(IV) Oxide Particles Suspended in Aqueous Solutions." J. Phys. Chem. B 101(19) (1997): 3746-3752.

563. Ohtani, Bunsho, Takayuki Yako, Yoriaki Samukawa, Seiichi Nishimoto, and Kiyoshi Kanamura. "An In Situ FT-IR Study on Photocatalytic Reaction at Semiconductor-Aqueous Solution Interface Mechanism of Photocatalytic N-Cyclization of (S)-Lysine." Chem. Lett. 1 (1997): 91-92.

564. Okabe, Kiyomi, Kazuhiro Sayama, Hitoshi Kusama, and Hironori Arakawa. "Photo-Oxidative Coupling of Methane over $\mathrm{TiO}_{2}$-Based Catalysts.” Chem. Lett. 5 (1997): 457-458.

565. Okamoto, Shingo. "Application of Titanium Dioxide as Photocatalysts for Coatings." Toso to Toryo 565 (1997): 27-34.

566. Okamoto, Yasuaki, Yasuhiro Kobayashi, Yasutake Teraoka, Satoshi Shobu, and Shuichi Kagawa. "Photooxidation of $\mathrm{M}(\mathrm{CO})_{6}(\mathrm{M}=\mathrm{Mo}, \mathrm{W})$ Adsorbed on $\mathrm{TiO}_{2}$." J. Chem. Soc., Faraday Trans. 93(15) (1997): 2561-2567.

567. Osora, Hiroyuki, Weijin Li, Luis Otero, and Marye Anne Fox. "Photosensitization of Nanocrystalline $\mathrm{TiO}_{2}$ Thin Films by a Polyimide Bearing Pendent Substituted-Ru(Bpy)32+ Groups." J. Photochem. Photobiol. B 43(3) (1998): 232-238.

568. Ozawa, Tatsuki, Kiyoshi Miyashita, and Tomoyuki Ooyoshi. "Preparation of $\mathrm{TiO}_{2}$ Thin Film by RF Magnetron Sputtering.” Gunma-Ken Kogyo Shikenjo Kenkyu Hokoku 1996 (1997): 114-117.

569. Pacaud, Bernard, Jean-Noel Bousseau, and Jacques Lemaire. "Nano-Titania as UV Blockers in Stains." Eur. Coat. J. 11 (1998): 842, 845-48.

570. Pacheco, J.E., M.R. Prairie, and L. Yellowhorse. "Photocatalytic Destruction of Chlorinated Solvents in Water with Solar Energy.” J. Solar Energy Engineering 115(3) (1993): 123-129.

571. Pacheco, James E., Cliff Carwile, Kimberly A. Magrini, and Mark Mehos. Developments in Solar Photocatalytisis for Destruction of Organics in Water, SAND 89-2236C. SNL, Albuquerque, NM (1989).

572. Pacheco, James E. and John T. Holmes. "Falling-Film and Glass-Tube Solar Photocatalytic Reactors for Treating Contaminated Water." Emerging Technologies in Hazardous Waste Management, eds. D. William Tedder and Frederick G. Pohland, ACS Symposium Series, no. 422. Washington, DC: ACS (1990): 40-51.

573. Pacheco, James E. and Craig E. Tyner. "Enhancement of Processes for Solar Photocatalytic Detoxification of Water." ASME International Solar Energy Conference, eds. J. Taylor Beard and M.A. Ebadain, New York, NY: ASME (1990) 163-166.

574. Pacheco, James E. and Larry Yellowhorse. Summary of Engineering-Scale Experiments for the Solar Detoxification of Water Project, SAND92-0385. SNL, Albuquerque, NM (1992).

575. Pappa, R., U. Cova, E. D’Angeli, and M. Giongo. "Improved Procedure for the Efficient Photocatalytic Decontamination of Polluted Groundwater.” Environ. Technol. 19(8) (1998): $851-56$. 
576. Park, Koon Ha and Kun Jun. "Titanium Dioxide Mediated Photocatalytic Conversion of Arenecarboxaldehyde Phthalazinylhydrazones to S-Triazolo[3,4-a]Phthalazines." Bull. Korean Chem. Soc. 19(9) (1998): 919-921.

577. Peill, N.J. and M.R. Hoffmann. "Solar-Powered Photocatalytic Fiber-Optic Cable Reactor for Waste Stream Remediation.” J. Sol. Energy Eng. 119(3) (1997): 229-236.

578. Peill, Nicola J., Lisa Bourne, and Michael R. Hoffmann. "Iron(III)-Doped Q-Sized $\mathrm{TiO}_{2}$ Coatings in a Fiber-Optic Cable Photochemical Reactor.” J. Photochem. Photobiol. A 108(2-3) (1997): 221228.

579. Peill, Nicola J. and Michael R. Hoffmann. "Mathematical Model of a Photocatalytic Fiber-Optic Cable Reactor for Heterogeneous Photocatalysis.” Environ. Sci. Technol. 32(3) (1998): 398-404.

580. Penuela, Gustavo A. and Damia Barcelo. "Comparative Degradation Kinetics of Alachlor in Water by Photocatalysis with $\mathrm{FeCl}_{3}, \mathrm{TiO}_{2}$ and Photolysis, Studied by Solid-Phase Disk Extraction Followed by Gas Chromatographic Techniques.” J. Chromatogr. A 754(1-2) (1996): 187-195.

581. Penuela, Gustavo A. and Damia Barcelo. "Photosensitized Degradation of Organic Pollutants in Water: Processes and Analytical Applications." TrAC, Trends Anal. Chem. 17(10) (1998): 605-612.

582. Peral, Jose and David F. Ollis. " $\mathrm{TiO}_{2}$ Photocatalyst Deactivation by Gas-Phase Oxidation of Heteroatom Organics.” J. Mol. Catal. A: Chem. 115(2) (1997): 347-354.

583. Peralta-Zamora, Patricio, Sandra Gomes De Moraes, Ronaldo Pelegrini, Mariwalde Freire, Jr., Juan Reyes, Hector Mansilla, and Nelson Duran. "Evaluation of $\mathrm{ZnO}, \mathrm{TiO}_{2}$ and Supported $\mathrm{ZnO}$ on the Photoassisted Remediation of Black Liquor, Cellulose and Textile Mill Effluents." Chemosphere 36(9) (1998): 2119-2133.

584. Perez, M., F. Torrades, X. Domenech, and J. Peral. "Photocatalytic Treatment of Paper Pulp Bleach Effluents." Quim. Anal. 16(3) (1997): 211-214.

585. Perez, Montserrat, Francesc Torrades, Jose A. Garcia-Hortal, Xavier Domenech, and Jose Peral. "Removal of Organic Contaminants in Paper Pulp Treatment Effluents by $\mathrm{TiO}_{2}$ Photocatalyzed Oxidation.” J. Photochem. Photobiol. A 109(3) (1997): 281-286.

586. Pernas, Enrique, Kevin E. O'Shea, and James Saiers. "The Influence of Mineralization Products on the Coagulation of $\mathrm{TiO}_{2}$ Photocatalyst." Prepr. Ext. Abstr. ACS Natl. Meet., Am. Chem. Soc., Div. Environ. Chem. 38(1) (1998): 18-21.

587. Pham, Hien N., Ebtisam Wilkins, A. Sharif Heger, and David Kauffman. "Quantitative Analysis of Variations in Initial Bacillus pumilus Spore Densities in Aqueous $\mathrm{TiO}_{2}$ Suspension and Design of a Photocatalytic Reactor." J. Environ. Sci. Health, Part A: Environ. Sci. Eng. Toxic Hazard. Subst. Control A32(1) (1997): 153-63.

588. Piccinini, Paola, Claudio Minero, Marco Vincenti, and Ezio Pelizzetti. "Photocatalytic Interconversion of Nitrogen-Containing Benzene Derivatives." J. Chem. Soc., Faraday Trans. 93(10) (1997): 1993-2000.

589. Piccinini, Paola, Claudio Minero, Marco Vincenti, and Ezio Pelizzetti. "Photocatalytic Mineralization of Nitrogen-Containing Benzene Derivatives." Catal. Today 39(3) (1997): 187-195. 
590. Pichat, P., C. Guillard, C. Hoang-Van, H. Delprat, D. Mas, F. Marme, T. Bouvier, and B. Servajean. "Laboratory Studies of the Phototransformation of Organic Compounds in the Presence of Water and/or Inorganic Particulate Solids." Transp. Chem. Transform. Pollut. Troposphere (1996), Volume 2, Issue Heterogeneous and Liquid Phase Processes, ed. Peter Warneck, Berlin, Germany: Springer (1996): 205-12.

591. Powell, Tony and Brian Butters. "Field Experience and System Enhancements of $\mathrm{TiO}_{2}$ Photocatalytic Remediation Systems." Chem. Oxid. 4, Technologies for the Nineties (1997): 185-192.

592. Pozzo, Roberto L., Miguel A. Baltanas, and Alberto E. Cassano. "Supported Titanium Oxide as Photocatalyst in Water Decontamination: State of the Art." Catal. Today 39(3) (1997): 219-231.

593. Prairie, M.R., J. Pacheco, and L.R. Evans. "Solar Detoxification of Water Containing Chlorinated Solvents and Heavy Metals via $\mathrm{TiO}_{2}$ Photocatalysis." Proceedings of ASME International Solar Engineering Conference, eds. William B. Stine, Jan Kreider, and Koichi Watanabe, New York, NY: ASME (1992): 1-8.

594. Prairie, M.R., B.M. Stange, and L.R. Evans. " $\mathrm{TiO}_{2}$ Photocatalysis for the Destruction of Organics and the Reduction of Heavy Metals." Photocatalytic Purification and Treatment of Water and Air, eds. D.F. Ollis and H. Al-Ekabi, Trace Metals in the Environment, ed. Jerome O. Nriagu, no. 3. New York, NY: Elsevier (1993): 353-363.

595. Prairie, Michael R., Lindsey R. Evans, and Sheryl L. Martinez. "Destruction of Organics and Removal of Heavy Metals via $\mathrm{TiO}_{2}$ Photocatalysis." Chemical Oxidation: Technology for the Nineties. Second International Symposium, eds. W. Wesley Eckenfelder, Alan R. Bowers, and John A. Roth, Lancaster, PA: Technomic Publishing Company (1994): 428-441.

596. Prairie, Michael R. and Bertha M. Stange. "Photocatalysis for The Treatment of Waste Water: Applications Involving the Removal of Metals." Proceedings from the Annual AIChE Heat Transfer Conference, AIChE (1993).

597. Prairie, Michael R., Bertha M. Stange, Philip J. Rodacy, and Pamela K. Leslie. Heterogeneous Photocatalysis for the Treatment of Synthetic and Actual Pinkwater, SAND94-0280A. SNL, Albuquerque, NM (1994).

598. Pramauro, Edmondo, Alessandra Bianco Prevot, Marco Vincenti, and Giovanna Brizzolesi. "Photocatalytic Degradation of Carbaryl in Aqueous Solutions Containing $\mathrm{TiO}_{2}$ Suspensions." Environ. Sci. Technol. 31(11) (1997): 3126-3131.

599. Pramauro, Edmondo, Alessandra Bianco Prevot, Marco Vincenti, and Roberta Gamberini. "Photocatalytic Degradation of Naphthalene in Aqueous $\mathrm{TiO}_{2}$ Dispersions: Effect of Nonionic Surfactants." Chemosphere 36(7) (1998): 1523-1542. 
600. Preis, Sergei, Marina Krichevskaya, and Anna Kharchenko. "Photocatalytic Oxidation of Aromatic Aminocompounds in Aquatic Solutions and Groundwater from Abandoned Military Base." Oxid. Technol. Water Wastewater Treat., Int. Conf., ed. Alfons Vogelpohl, Paper no. 42, ClausthalZellerfield, Germany: Papierflieger Verlag (1996).

601. Preis, Sergei, Yelena Terentyeva, and Aleksei Rozkov. "Photocatalytic Oxidation of Phenolic Compounds in Wastewater from Oil Shale Treatment." Oxid. Technol. Water Wastewater Treat., Int. Conf., ed. Alfons Vogelpohl, Paper no. 56, Clausthal-Zellerfield, Germany: Papierflieger Verlag (1996).

602. Preis, Sergei, Yelena Terentyeva, and Aleksei Rozkov. "Photocatalytic Oxidation of Phenolic Compounds in Wastewater from Oil Shale Treatment." Water Sci. Technol. 35(4), Oxidation Technologies for Water and Wastewater Treatment (1997): 165-174.

603. Prousek, Josef and Dusan Velic. "Photocatalytic Degradation of Phenol by Aqueous Semiconductor Dispersions." Chem. Listy 90(11) (1996): 906-910.

604. Przyluski, Jan and Krystyna Kolbrecka. "Titanium Oxides as New Electrode Materials." Pr. Nauk. Inst. Technol. Nieorg. Nawozow Miner. Politech. Wroclaw. 42 (1995): 52-64.

605. Pulgarin, Cesar and John Kiwi. "Overview on Photocatalytic and Electrocatalytic Pretreatment of Industrial Non-Biodegradable Pollutants and Pesticides.” Chimia 50(3) (1996): 50-55.

606. Qu, Ping, Jincai Zhao, Zang Ling, Tao Shen, and Hisao Hidaka. "Enhancement of the Photoinduced Electron Transfer from Cationic Dyes to Colloidal $\mathrm{TiO}_{2}$ Particles by Addition of an Anionic Surfactant in Acidic Media." Colloids Surf. A 138(1) (1998): 39-50.

607. Quintana, J.A., P.G. Boj, J. Crespo, M. Pardo, and M.A. Satorre. "Line-Focusing Holographic Mirrors for Solar Ultraviolet Energy Concentration.” Appl. Opt. 36(16) (1997): 3689-3693.

608. Raftery, Daniel, Sonjong Hwang, and Chris Petucci. "Investigations of Photocatalytic Surface Chemistry Using In Situ Solid- State NMR.” The Spectrum 10(1) (1997): 1-6.

609. Ramanathan, Kumaran, David Avnir, Alexander Modestov, and Ovadia Lev. "Sol-Gel Derived Ormosil-Exfoliated Graphite- $\mathrm{TiO}_{2}$ Composite Floating Catalyst: Photodeposition of Copper." Chem. Mater. 9(11) (1997): 2533-2540.

610. Randive, Rajul V. Synthesis, Characterization and Catalytic Evaluation of Titania Modified with Tethered Organic Compounds. Ph.D. diss., Clarkson Univ. (1998).

611. Ranjit, K.T. and B. Viswanathan. "Photocatalytic Reduction of Nitrite and Nitrate Ions over Doped $\mathrm{TiO}_{2}$ Catalysts.” J. Photochem. Photobiol. A 107(1-3) (1997): 215-220.

612. Ranjit, K.T. and B. Viswanathan. "Photocatalytic Reduction of Nitrite and Nitrate Ions to Ammonia on M/TiO2 Catalysts." J. Photochem. Photobiol. A 108(1) (1997): 73-78.

613. Ranjit, K.T. and B. Viswanathan. "Synthesis, Characterization and Photocatalytic Properties of IronDoped $\mathrm{TiO}_{2}$ Catalysts.” J. Photochem. Photobiol. A 108(1) (1997): 79-84. 
614. Ranjit, Koodali T., Itamar Willner, Stefan Bossmann, and Andre Braun. "Iron(III) PhthalocyanineModified Titanium Dioxide: A Novel Photocatalyst for the Enhanced Photodegradation of Organic Pollutants." J. Phys. Chem. B 102(47) (1998): 9397-9403.

615. Ranjit, Koodali Thazhathaveetil, Ernesto Joselevich, and Itamar Willner. "Enhanced Photo- catalytic Degradation of Pi-Donor Organic Compounds by N,N'-Dialkyl-4,4'-Bipyridinium-Modified $\mathrm{TiO}_{2}$ Particles." J. Photochem. Photobiol. A 99(2-3) (1996): 185-189.

616. Rao, N.N. and S. Dube. "Photocatalytic Degradation of Reactive Orange 84 (RO 84) in Dye-House Effluent Using Single Pass Reactor." Stud. Surf. Sci. Catal. 113, Recent Advances in Basic and Applied Aspects of Industrial Catalysis (1998): 1045-1050.

617. Rao, N.N., and Sangeeta Dube. " $\mathrm{TiO}_{2}$-Catalyzed Photodegradation of Reactive Orange 84 and Alizarin Red S Biological Stain.” Indian J. Chem. Technol. 4(1) (1997): 1-6.

618. Rao, Tata Narasinga, Yasuo Komoda, Nobuyuki Sakai, and Akira Fujishima. "Photoeffects on Electrorheological Properties of $\mathrm{TiO}_{2}$ Particle Suspensions.” Chem. Lett. 4 (1997): 307-308.

619. Raupp, Gregory B., Jill A. Nico, Suneetha Annangi, Rajnish Changrani, and Rao Annapragada. "Two-Flux Radiation-Field Model for an Annular Packed-Bed Photocatalytic Oxidation Reactor." AIChE J. 43(3) (1997): 792-801.

620. Ray, Ajay K. "Novel Photocatalytic Reactors for Water Purification. Sustainable Energy Environ. Technol., Proc. Asia-Pac. Conf. (1996), ed. Paul F. Greenfield, Singapore: World Scientific (1996): $25-32$.

621. Ray, Ajay K. "A New Photocatalytic Reactor for Destruction of Toxic Water Pollutants by Advanced Oxidation Process." Catal. Today 44(1-4) (1998): 357-368.

622. Ray, Ajay K. and Antonie A.C.M. Beenackers. "Novel Swirl-Flow Reactor for Kinetic Studies of Semiconductor Photocatalysis." AIChE J. 43(10) (1997): 2571-2578.

623. Ray, Ajay K. and Antonie A.C.M. Beenackers. "Development of a New Photocatalytic Reactor for Water Purification." Catal. Today 40(1) (1998): 73-83.

624. Ray, Ajay K. and Antonie A.C.M. Beenackers. "Novel Photocatalytic Reactor for Water Purification." AIChE J. 44(2) (1998): 477-483.

625. Ray, Ajay K. and Dingwang Chen. "Photocatalytic Degradation of Organics in Aqueous Suspensions." Phys., Chem., Therm. Technol., Int. Conf. Rem. Chlorinated Recalcitrant Compd., 1st, eds. Godage B. Wickramanayake and Robert E. Hinchee, Columbus, Ohio: Battelle Press (1998): 443-446.

626. Renzi, Cecilia, Chantal Guillard, Jean-Marie Herrmann, Pierre Pichat, and Giancarlo Bald. "Effects of Methanol, Formamide, Acetone and Acetate Ions on Phenol Disappearance Rate and Aromatic Products in UV-Irradiated $\mathrm{TiO}_{2}$ Aqueous Suspensions." Chemosphere 35(4) (1997): 819-826.

627. Reutergardh, Lars Baetz and Mallika Iangphasuk. "Photocatalytic Decolorization of Reactive Azo Dye: a Comparison between $\mathrm{TiO}_{2}$ and CdS Photocatalysis." Chemosphere 35(3) (1997): 585-596.

628. Rhodacy, Philip J., Pamela K. Leslie, Michael R. Prairie, Bertha Stange, Steve Showalter, Cliff L. Renschler, Christine A. White, Richard Buss, Raymond Sierka, and Curtis Bryant. Destruction of Explosives in Groundwater and Process Water Using Photocatalytic and Biological Methods, 
SAND96-0929. SNL, Albuquerque, NM (1996).

629. Richardson, Susan D., Alfred D. Jr. Thruston, Timothy W. Collette, Kathleen S. Patterson, Benjamin W. Jr. Lykins, and John C. Ireland. "Identification of $\mathrm{TiO}_{2} / \mathrm{UV}$ Disinfection Byproducts in Drinking Water.” Environ. Sci. Technol. 30(11) (1996): 3327-3334.

630. Rideh, L., A. Wehrer, D. Ronze, and A. Zoulalian. "Photocatalytic Degradation of 2-Chlorophenol in $\mathrm{TiO}_{2}$ Aqueous Suspension: Modeling of Reaction Rate." Ind. Eng. Chem. Res. 36(11) (1997): 4712-4718.

631. Rincon, M.E., C. Corripio, and J. Ruiz-Garcia. "Photoelectrochemical Characterization of Multilayer Structures Obtained by Chemical Bath and Screen Printing Techniques." Proc. Electrochem. Soc. 98-5, Environmental Issues in the Electronics/Semiconductor Industries and Electrochemical/Photochemical Methods for Pollution Abatement (1998): 213-31.

632. Robert, Didier, Franck Rohr, and Jean-Victor Weber. "Influence of Some Factors on the Photocatalytic Degradation of Acetic Acid in an Aqueous Suspension of $\mathrm{TiO}_{2}$." C.R. Acad. Sci., Ser. IIb: Mec., Phys., Chim., Astron. 325(12) (1997): 733-738.

633. Robertson, Peter K.J., Linda A. Lawton, Benjamin J.P.A. Cornish, and Marcel Jaspars. "Processes Influencing the Destruction of Microcystin-LR by $\mathrm{TiO}_{2}$ Photocatalysis." J. Photochem. Photobiol. A 116(3) (1998): 215-219.

634. Robertson, Peter K.J., Linda A. Lawton, Burkhard Munch, and Julien Rouzade. "Destruction of Cyanobacterial Toxins by Semiconductor Photocatalysis." Chem. Commun. 4 (1997): 393-394.

635. Romero, Roberto L., Orlando M. Alfano, and Alberto E. Cassano. "Cylindrical Photocatalytic Reactors. Radiation Absorption and Scattering Effects Produced by Suspended Fine Particles in an Annular Space." Ind. Eng. Chem. Res. 36(8) (1997): 3094-3109.

636. Rose, Timothy L. and Peter J. Marren. "Destruction of Agent Simulants by the Photo-Fenton Reaction." Proc. ERDEC Sci. Conf. Chem. Biol. Def. Res., ed. Dorothy A. Berg, Springfield, VA: National Technical Information Service (1996): 847-853.

637. Rusu, C.N. and J.T. Yates, Jr. "Defect Sites on $\mathrm{TiO}_{2}(110)$. Detection by $\mathrm{O}_{2}$ Photodesorption." Langmuir 13(16) (1997): 4311-4316.

638. Sadeghi, M., W. Liu, T-G. Zhang, P. Stavropoulos, and B. Levy. "Role of Photoinduced Charge Carrier Separation Distance in Heterogeneous Photocatalysis: Oxidative Degradation of $\mathrm{CH}_{3} \mathrm{OH}$ Vapor in Contact with $\mathrm{Pt} / \mathrm{TiO}_{2}$ and Cofumed $\mathrm{TiO}_{2}-\mathrm{Fe}_{2} \mathrm{O}_{3}$." J. Phys. Chem. 100(50) (1996): 1946619474.

639. Sadeghi, Mahmoud. Photocatalytic Oxidative Degradation of Benzene and Toluene Vapors over Titanium Dioxide. Ph.D. diss., Boston Univ. (1998).

640. Saeki, Yoshimitsu. "Multifunctional Tiles.” Kogyo Zairyo 45(10) (1997): 71-73.

641. Sahyun, M.R.V. "Time-Resolved Dielectric Loss for Characterization of Photoconductive and Photocatalytic Materials.” J. Imaging Sci. Technol. 41(2) (1997): 127-134. 
642. Sahyun, M.R.V. and N. Serpone. "Primary Events in the Photocatalytic Deposition of Silver on Nanoparticulate $\mathrm{TiO}_{2} . "$ Langmuir 13(19) (1997): 5082-5088.

643. Saito, Toshiyuki, Jyunji Horie, Yoshio Nara, Kinji Onoda, and Toshio Morioka. "Bactericidal Effect of Powdered $\mathrm{TiO}_{2}$ with Photo-Catalytic Reaction on S. mutans." J. Dental Health 37 (1987): 520 521.

644. Saito, Toshiyuki, Yoshio Nara, Toshio Morioka, and Kinji Onoda. "Antibacterial Effect of Powdered $\mathrm{TiO}_{2}$ with Photocatalytic Reaction on Streptococcus mutans Strain AHT." J. Dental Health 36 (1986): 490-491.

645. Saitoh, Tokuyoshi. "Development of Titanium Oxide Photocatalyst." JETI 44(10) (1996): 63-65.

646. Sakai, Hideki, Ryo Baba, Kazuhito Hashimoto, Yoshinobu Kubota, and Akira Fujishima. "Selective Killing of a Single Cancerous T24 Cell with $\mathrm{TiO}_{2}$ Semiconduction Microelectrode under Irradiation." Chem. Lett. (1995): 185-186.

647. Sakai, Hideki, Etsuro Ito, Ru-Xiong Cai, Toru Yoshioka, Yoshinobu Kubota, Kazuhito Hashimoto, and Akira Fujishima. "Intracellular $\mathrm{Ca}^{+2}$ Concentration Change of T24 Cell under Irradiation in the Presence of $\mathrm{TiO}_{2}$ Ultrafine Particles.” Biochim. Biophys. Acta 1201 (1994): 259-265.

648. Sakamoto, Kazuhiko, Yoshio Tonegawa, Jun Inoue, Osamu Ishitani, and Hitoshi Kohno. "Decomposition of Trace-Amount of VOC Using UV-Light and Photocatalyst." Proc. Inst. Environ. Sci. Technol. (1998), 44th (Contamination Control) (1998): 52-57.

649. Sakamoto, Kazuhiko, Shinobu Ushijima, Takako Tsuji, Osamu Ishitani, and Toshiaki Fujii. "Degradation of Trace Gaseous Compounds Using Fixed Photocatalyst and UV Light - Air Cleaning Technology Combined with Absorption of Gaseous Pollutants into Water." Proc. Inst. Environ. Sci. Technol. (1998), 44th (Contamination Control) (1998): 63-66.

650. Sakurada, Tsukasa. "Photo-Semiconductor Sterilization by Low-Temperature Melt Injection Method." Hyomen Gijutsu 49(5) (1998): 439-44.

651. Sanchez, Laura, Jose Peral, and Xavier Domenech. "Photocatalyzed Destruction of Aniline in UV-Illuminated Aqueous $\mathrm{TiO}_{2}$ Suspensions.” Electrochim. Acta 42(12) (1997): 1877-1882.

652. Sangchakr, Benchang, Teruaki Hisanaga, and Keiichi Tanaka. "Photocatalytic Degradation of 1,1-Difluoroethane (HFC-152a).” Chemosphere 36(9) (1998): 1985-1992.

653. Sangchakr, Benchang and Keiichi Tanaka. "Development of Protection Technique of Ozone Layer and Its Evaluation. Photodegradation of 1,1-Difluoroethane." Global Environ. Res. Jpn. (1996), Pt. 1, 108-13, Tokyo, Japan: Environment Agency, Global Environment Dep., Research and Information Office (1996).

654. Sano, Youichi, Kenichi Nishi, Masaru Matsumoto, Shunichi Yoshinaga, and Toshiyuki Nagaishi. "Disposal of TNT Wastes with $\mathrm{TiO}_{2}$ Photocatalyst Powder under UV Radiation. I." Kayaku Gakkaishi 58(2) (1997): 47-52. 
655. Sasaki, T., R. Rozbicki, Y. Matsumoto, N. Koshizaki, S. Terauchi, and H. Umehara. "Preparation and Characterization of Nanocomposite Composed of $\mathrm{TiO}_{2}$ as Active Matrix." Mater. Res. Soc. Symp. Proc., 457, Nanophase and Nanocomposite Materials II (1997): 425-430.

656. Sattler, Melanie Louise. Rates of Photocatalytic Oxidation of Organic Compounds in Air over Titanium Dioxide. Ph.D. diss., Univ. of Texas (1996).

657. Sawada, Katsuya and Katsuhiko Hirano. "Effect of Ultrasonic Irradiation on Photocatalytic Decomposition of Chlorinated Organic Compounds.” Mizu Shori Gijutsu 39(6) (1998): 277-281.

658. Sawunyama, P., A. Yasumori, and K. Okada. "The Nature of Multilayered $\mathrm{TiO}_{2}-\mathrm{Based}_{\text {Photo- }}$ catalytic Films Prepared by a Sol-Gel Process.” Mater. Res. Bull. 33(5) (1998): 795-801.

659. Sawunyama, Phillip, Lei Jiang, Akira Fujishima, and Kazuhito Hashimoto. "Photodecomposition of a Langmuir-Blodgett Film of Stearic Acid on $\mathrm{TiO}_{2}$ Film Observed by In Situ Atomic Force Microscopy and FT-IR.” J. Phys. Chem. B 101(51) (1997): 11000-11003.

660. Sayama, Kazuhiro and Hironori Arakawa. "Stoichiometric Decomposition of Water over Semiconductor Photocatalyst." Shokubai 39(3) (1997): 252-256.

661. Schaar-Gabrial, E., N. Alonso-Vante, and H. Tributsch. "STM-Photoeffects Mediated by Water Adsorption on Photocatalytic $\left(\mathrm{RuS}_{2}, \mathrm{TiO}_{2}\right)$ Materials." Surf. Sci. 366(3) (1996): 508-518.

662. Schmelling, Daniel C. and Kimberly A. Gray. "Photocatalytic Transformations of TNT in Titania Slurries: an Analysis of the Role of Interfacial Nitrogen Reduction Utilizing .Gamma.-Radiolysis. Chem. Oxid. 4, Technologies for the Nineties (1997): 173-183.

663. Schmelling, Daniel C., Kimberly A. Gray, and Prashant V. Kamat. "The Influence of Solution Matrix on the Photocatalytic Degradation of TNT in $\mathrm{TiO}_{2}$ Slurries." Water Res. 31(6) (1997): 14391447.

664. Schwarz, Peter F., Nicholas J. Turro, Stefan H. Bossmann, Andre M. Braun, Aboel-Magd A. Abdel Wahab, and Heinz Duerr. "A New Method to Determine the Generation of Hydroxyl Radicals in Illuminated $\mathrm{TiO}_{2}$ Suspensions.” J. Phys. Chem. B 101(36) (1997): 7127-7134.

665. Schwitzgebel, Joerg, John G. Ekerdt, Futoshi Sunada, Sten-Eric Lindquist, and Adam Heller. "Increasing the Efficiency of the Photocatalytic Oxidation of Organic Films on Aqueous Solutions by Reactively Coating the $\mathrm{TiO}_{2}$ Photocatalyst with a Chlorinated Silicone." J. Phys. Chem. B 101(14) (1997): 2621-2624.

666. Sclafani, Antonino, Leonardo Palmisano, and Gianluca Farneti. "Synthesis of 2-Hydroxybenzoic Acid from $\mathrm{CO}_{2}$ and Phenol in Aqueous Heterogeneous Photocatalytic Systems." Chem. Commun. 6 (1997): 529-530.

667. Serpone, N., P. Calza, A. Salinaro, L. Cai, A. Emeline, H. Hidaka, S. Horikoshi, and E. Pelizzetti. "What Becomes of Nitrogen in the Photoelectrochemical and Photocatalyzed Mineralization of N-Containing Substances at Titania/Water Interfaces?" Proc. Electrochem. Soc. 97-20, Photoelectrochemistry (1997): 301-320.

668. Serpone, N., D. Lawless, and E. Pelizzetti. "Subnanosecond Characteristics and Photophysics of Nano-Sized $\mathrm{TiO}_{2}$ Particulates from $\mathrm{R}_{\text {part }}=10 \mathrm{~A}$ to $134 \mathrm{~A}$ : Meaning for Heterogeneous Photocatalysis." NATO ASI Ser. 3(12) (1996): 657-773. 
669. Serpone, Nick. "Relative Photonic Efficiencies and Quantum Yields in Heterogeneous Photocatalysis." J. Photochem. Photobiol. A 104(1-3) (1997): 1-11.

670. Serpone, Nick. "Relative Photonic Efficiencies and Quantum Yields in Heterogeneous Photocatalysis." J. Adv. Oxid. Technol. 2(1) (1997): 203-216.

671. Serrano, B. and H. de Lasa. "Photocatalytic Degradation of Water Organic Pollutants. Kinetic Modeling and Energy Efficiency." Ind. Eng. Chem. Res. 36(11) (1997): 4705-4711.

672. Sgalari, G., G. Camera-Roda, and F. Santarelli. "Discrete Ordinate Method in the Analysis of Radiative Transfer in Photocatalytically Reacting Media." Int. Commun. Heat Mass Transfer 25(5) (1998): 651-660.

673. Shama, G., C.J. Peppiatt, M. Booth, and E.F.B. Croft. "A Versatile Thin Film UV Contactor." Int. Congr. Electr. Appl., 13th, WTII51-WTII57, London, UK: Institute of Materials (1996).

674. Sharma, Bhoopendra Kumar, Rohit Ameta, Jatinder Kaur, and Suresh C. Ameta. "Photocatalytic Reduction of Carbon Dioxide over Ferrocyanide-Coated Titanium Dioxide Powder." Int. J. Energy Res. 21(10) (1997): 923-929.

675. Sharma, Bhoopendra Kumar, Jitenrdra Vardia, Pratibha Rao, and Suresh C. Ameta. "Photo- catalytic Formation of Formic Acid and Formaldehyde from Carbon Dioxide in the Presence of Neutral RedCoated Titaniumdioxide." Hung. J. Ind. Chem. 26(1) (1998): 1-5.

676. Shen, Junquan. "Review on Ecological Ceramic and Photocatalyst." Taoci 2 (1998): 7-10.

677. Sheng, J., J. Karasawa, and T. Fukami. "Thickness Dependence of Photocatalytic Activity of Anatase Film by Magnetron Sputtering." J. Mater. Sci. Lett. 16(21) (1997): 1709-1711.

678. Shi, Liyi, Chunzhong Li, Dingye Fang, Hongchen Gu, and BinZhang Zhongyan Hua. "Photocatalytic Destruction of Phenol with Ultrafine Titania Particles." Huadong Ligong Daxue Xuebao 24(3) (1998): 291-297.

679. Shiomori, Koichiro, Yoshinobu Kawano, Yoshinari Baba, Hiroaki Mitani, and Yasuo Hatate. "Effects of UV Irradiation and Photocatalysis of $\mathrm{TiO}_{2}$ on the Autoxidation Rate of Linoleic Acid." Kagaku Kogaku Ronbunshu 23(5) (1997): 694-700.

680. Shiraishi, Fumihide, Satoru Fukinbara, and Katsuyuki Nakano. "Ethylene Decomposition by a Photocatalytic Reactor.” Kemikaru Enjiniyaringu 42(4) (1997): 262-266.

681. Shivalingappa, L., J. Sheng, and T. Fukami. "Photocatalytic Effect in Platinum Doped Titanium Dioxide Films." Vacuum 48(5) (1997): 413-416.

682. Shklover, V., Yu. E. Ovchinnikov, L.S. Braginsky, S.M. Zakeeruddin, and M. Graetzel. "Structure of Organic/Inorganic Interface in Assembled Materials Comprising Molecular Components. Crystal Structure of the Sensitizer Bis[(4,4'-Carboxy-2,2'-Bipyridine) (Thiocyanato)]Ruthenium(II)." Chem. Mater. 10(9) (1998): 2533-2541.

683. Showalter, S.K., M.R. Prairie, B.M. Stange, P.J. Rodacy, and P.K. Leslie. "Photodestruction of Explosives in Process Water." 210th American Chemical Society National Meeting (1995). 
684. Siemon U., S. Rauer, R. Dillert, and D. Bahnemann. "Photocatalytic Activity of Commercially Available Titanium Dioxide Materials." IPS-12 - Twelfth International Conference on Photochemical Conversion and Storage of Solar Energy (1998).

685. Singhal, Bhawana, Anugya Porwal, Ajay Sharma, Rameshwar Ameta, and Suresh C. Ameta. "Photocatalytic Degradation of Cetylpyridinium Chloride over Titanium Dioxide Powder." J. Photochem. Photobiol. A 108(1) (1997): 85-88.

686. Smith, B.A., D.M. Waters, A.E. Faulhaber, M.A. Kreger, T.W. Roberti, and J.Z. Zhang. "Preparation and Ultrafast Optical Characterization of Metal and Semiconductor Colloidal NanoParticles." J. Sol-Gel Sci. Technol. 9(2) (1997): 125-137.

687. Sobczynski, A., J. Gimenez, and S. Cervera-March. "Photodecomposition of Phenol in a Flow Reactor. Adsorption and Kinetics.” Monatsh. Chem. 128(11) (1997): 1109-1118.

688. Sobczynski, Andrzej, Jaime Gimenez, and Salvador Cervera-March. "A Fluidized Photoreactor Design for Water Detoxification by Photocatalysis." Pol. J. Appl. Chem. 40(1-2) (1996): 103-14.

689. Somasundaram, N. and C. Srinivasan. "Photoredox Reactions of $\mathrm{ArXCOOH}\left(\mathrm{X}=\mathrm{CH}_{2}, \mathrm{OCH}_{2}\right.$, $\mathrm{SCH}_{2}, \mathrm{SOCH}_{2}$, or $\mathrm{SO}_{2} \mathrm{CH}_{2}$ ) on $\mathrm{TiO}_{2}$." J. Photochem. Photobiol. A 99(1) (1996): 67-70.

690. Somasundaram, N. and C. Srinivasan. "Oxygenation of Aldimines and Deoxygenation of Nitrones on Irradiated $\mathrm{TiO}_{2} . "$ Tetrahedron Lett. 39(21) (1998): 3547-3550.

691. Sopajaree, Khajornsak. Photocatalytic Oxidation of Methylene Blue by Titanium Dioxide in an Integrated Photoreactor-Membrane Filtration Unit. Ph.D. diss., Univ. of Texas (1997).

692. Sopyan, I., M. Watanabe, S. Murasawa, K. Hashimoto, and A. Fujishima. "A Film-Type Photocatalyst Incorporating Highly Active $\mathrm{TiO}_{2}$ Powder and Fluororesin Binder: Photocatalytic Activity and Long-Term Stability.” J. Electroanal. Chem. 415(1-2) (1996): 183-186.

693. Sopyan, Iis, Mitsuru Watanabe, Sadao Murasawa, Kazuhito Hashimoto, and Akira Fujishima. "An Efficient $\mathrm{TiO}_{2}$ Thin-Film Photocatalyst: Photocatalytic Properties in Gas-Phase Acetaldehyde Degradation.” J. Photochem. Photobiol. A 98(1-2) (1996): 79-86.

694. Stafford, U., K.A. Gray, and P.V. Kamat. "Photocatalytic Degradation of 4-Chlorophenol: A Mechanistically-Based Model.” Res. Chem. Intermed. 23(4) (1997): 355-388.

695. Stafford, Ulick, Kimberly A. Gray, and Prashant V. Kamat. "Photocatalytic Degradation of 4-Chlorophenol: the Effects of Varying $\mathrm{TiO}_{2}$ Concentration and Light Wavelength." J. Catal. 167(1) (1997): 25-32.

696. Stafford, Ulick, Kimberly A. Gray, and Prashant V. Kamat. "Photocatalytic Oxidation of 4-Chlorophenol on Titanium Dioxide: A Comparison with Gamma.-Radiolysis." Chem. Oxid. 4, Technologies for the Nineties (1997): 193-204.

697. Stanley, Andrew, Bruce Verity, and Dennis Matthews. "Minimizing the Dark Current at the DyeSensitized $\mathrm{TiO}_{2}$ Electrode." Sol. Energy Mater. Sol. Cells 52(1-2) (1998): 141-154.

698. Stevens, Lisa, John A. Lanning, Larry G. Anderson, William A. Jacoby, and Nicholas Chornet. "Investigation of the Photocatalytic Oxidation of Low-Level Carbonyl Compounds." J. Air Waste 
Mgmt. Assoc. 48(10) (1998): 979-984.

699. Stevens, Lisa, John A. Lanning, Larry G. Anderson, William A. Jacoby, and Nicholas Chornet. "Photocatalytic Oxidation of Organic Pollutants Associated with Indoor Air Quality." 91st Annu. Meet. Air Waste Mgmt. Assoc. Air and Waste Management Association (1998): 1-14.

700. Stevenson, Mary, Kerry Bullock, Wen-Yuan Lin, and Krishnan Rajeshwar. "Sonolytic Enhancement of the Bactericidal Activity of Irradiated Titanium Dioxide Suspensions in Water." Res. Chem. Intermed. 23(4) (1997): 311-323.

701. Stewart, Gina Marie. Photoinduced Electron Transfer Reactions in Heterogeneous Photocatalysis and in Macromolecular Arrays (Ring Opening, Titanium Dioxide, Polyether Dendrimer). Ph.D. diss., Univ. of Texas (1996).

702. Stockenstroem, Sonja, David de Villiers, W. J. Engelbrecht, Gordon S. Shephard, Eric W. Sydenham, Pieter G. Thiel, and G.F.S. Wessels. "Photocatalytic Decomposition of Microcystins in Water." Mycotoxins Phycotoxins--Dev. Chem., Toxicol. Food Saf. Proc. Int. IUPAC Symp. Mycotoxins Phycotoxins, 9th, ed. Marina Miraglia, Fort Collins, CO: Alaken (1998): 517-522.

703. Stone, Victor F., Jr. and Robert J. Davis. "Synthesis, Characterization, and Photocatalytic Activity of Titania and Niobia Mesoporous Molecular Sieves." Chem. Mater. 10(5) (1998): 1468-1474.

704. Stringer, Bradley, Amy Imrich, and Lester Kobzik. "Flow Cytometric Assay of Lung Macrophage Uptake of Environmental Particulates." Cytometry 20 (1995): 23-32.

705. Sturini, Michela, Elisa Fasani, Cristina Prandi, and Angelo Albini. "Titanium Dioxide Photocatalyzed Degradation of Some Anilides.” Chemosphere 35(5) (1997): 931-937.

706. Su, Bitao, Yufeng He, Xingyong Li, Enhui Lin, and Qinlin Li. "Photocatalytic Oxidation of Cyclohexane on Ultra-Fine $\mathrm{TiO}_{2}$ Particles." Indian J. Chem., Sect. A: Inorg., Bio-Inorg., Phys., Theor. Anal. Chem. 36A 9 (1997): 785-788.

707. Su, Lianyong and Zuhong Lu. "Photochromic and Photocatalytic Behaviors on Immobilized $\mathrm{TiO}_{2}$ Particulate Films.” J. Photochem. Photobiol. A 107(1-3) (1997): 245-248.

708. Su, Lianyong and Zuhong Lu. "Spectroelectrochemical Study of $\mathrm{TiO}_{2}$ Particulate Films." Spectrochim. Acta, Part A 53A(11) (1997): 1719-1722.

709. Su, Y., Y. Wang, J.L. Daschbach, T.B. Fryberger, M.A. Henderson, J. Janata, and C.H.F. Peden. "Gamma-Ray Destruction of EDTA Catalyzed by Titania." J. Adv. Oxid. Technol. 3(1) (1998): 63-69.

710. Subrahmanyam, M., K.V. Subba Rao, M. Rajesh Babu, and B. Srinivas. "Photocatalytic Degradation of Textile Dyes Using $\mathrm{TiO}_{2}$-Based Catalysts." Indian J. Environ. Prot. 18(4) (1998): $266-272$.

711. Sugiura, T., T. Yoshida, and H. Minoura. "Designing a $\mathrm{TiO}_{2}$ Nano-Honeycomb Structure Using Photoelectrochemical Etching.” Electrochem. Solid-State Lett. 1(4) (1998): 175-177.

712. Suhardono, Pusparatu Dan E. "Study of the Photocatalytic Degradation of Asulam by a $\mathrm{TiO}_{2}$ 
Suspension Method.” Lembaran Publ. Lemigas 31(2) (1998): 3-9.

713. Sukharev, Valeriy and Robert Kershaw. "Concerning the Role of Oxygen in Photocatalytic Decomposition of Salicylic Acid in Water.” J. Photochem. Photobiol. A 98(3) (1996): 165-169.

714. Sun, Fengyu, Ming Wu, Wenzhao Li, Xinyong Li, Wanzhen Gu, and Fudong Wang. "Relation- ship between Crystallite Size and Photocatalytic Activity of Titanium Dioxide." Cuihua Xuebao 19(3) (1998): 229-233.

715. Sunada, Futoshi and Adam Heller. "Effects of Water, Salt Water, and Silicone Overcoating of the $\mathrm{TiO}_{2}$ Photocatalyst on the Rates and Products of Photocatalytic Oxidation of Liquid 3-Octanol and 3-Octanone.” Environ. Sci. Technol. 32(2) (1998): 282-286.

716. Sunada, Kayano, Yoshihiko Kikuchi, Kazuhito Hashimoto, and Akira Fujishima. "Bactericidal and Detoxification Effects of $\mathrm{TiO}_{2}$ Thin Film Photocatalysts.” Environ. Sci. Technol. 32(5) (1998): 726728.

717. Suzuki, Ken-Ichirou. "Photocatalytic Air Purification on $\mathrm{TiO}_{2}$ Coated Honeycomb Support." Proceedings of the First International Conference on $\mathrm{TiO}_{2}$ Photocatalytic Purification and Treatment of Water and Air, eds. D.F. Ollis and H. Al-Ekabi, New York, NY, Elsevier Science Publishers B.V. (1993): 421-34.

718. Sviridov, D.V. "Photoelectrochemical Study of the Mechanism of Spectral Sensitization of Semiconductors by Aggregated Polymethine Dyes." Zh. Nauchn. Prikl. Fotogr. 42(5) (1997): $33-44$.

719. T-Raissi, Alit, Nazim Z. Muradov, Donald Muzzey, and Charles R. Painter. "Design and Analysis of a 5 SCFM Photocatalytic Reactor for Purification of NG-Contaminated VOCs in Air." Chem. Oxid. 1995 (1997): 5314-5324.

720. Tada, Hiroaki, Yasuyuki Kubo, Manabu Akazawa, and Seishiro Ito. "Promoting Effect of SiOx Monolayer Coverage of $\mathrm{TiO}_{2}$ on the Photoinduced Oxidation of Cationic Surfactants." Langmuir 14(11) (1998): 2936-2939.

721. Tada, Hiroaki and Makiko Tanaka. "Surface Properties of $\mathrm{SiO}_{\mathrm{x}}$ Monolayer Photochemically Formed on Oxide Semiconductors." Thin Solid Films 281-282(1-2) (1996): 404-408.

722. Tada, Hiroaki and Makiko Tanaka. "Dependence of $\mathrm{TiO}_{2}$ Photocatalytic Activity upon Its Film Thickness." Langmuir 13(2) (1997): 360-364.

723. Tahiri, Halima, Yahia Ait Ichou, and Jean-Marie Herrmann. "Photocatalytic Degradation of Chlorobenzoic Isomers in Aqueous Suspensions of Neat and Modified Titania." J. Photochem. Photobiol. A 114(3) (1998): 219-226.

724. Tahiri, Halima and Nick Serpone. "Detoxification and Desilvering of Photographic Processing Effluents by an Alternative Technology: Photocatalysis at Semiconductor/Solution Interfaces." J. Adv. Oxid. Technol. 1(2) (1996): 179-188.

725. Takeda, Norihiko, Naoko Iwata, Tsukasa Torimoto, and Hiroshi Yoneyama. "Influence of Carbon Black as an Adsorbent Used in $\mathrm{TiO}_{2}$ Photocatalyst Films on Photodegradation Behaviors of Propyzamide. J. Catal. 177(2) (1998): 240-246.

726. Takeda, Norihiko, Masayuki Ohtani, Tsukasa Torimoto, Susumu Kuwabata, and Hiroshi Yoneyama. 
"Evaluation of Diffusibility of Adsorbed Propionaldehyde on Titanium Dioxide-Loaded Adsorbent Photocatalyst Films from Its Photodecomposition Rate.” J. Phys. Chem. B 101(14) (1997): 26442649.

727. Tamai, Motoharu, Yoshiya Kera, and Keiji Hashimoto. "Sound Absorbing Concrete with Characteristics of NOx Absorption.” Semento, Konkurito Ronbunshu 51 (1997): 870-875.

728. Tanaka, Jun. “Titanium Oxide Photocatalyst Materials, Super Titania.” Kogyo Zairyo 45(10) (1997): $54-55$.

729. Tanaka, Keiichi. "Decomposition of Harmful Substances in Water by Photocatalysts." Kagaku Sochi 39(7) (1997): 59-61.

730. Tanaka, Keiichi. "Photocatalytic Degradation of Volatile Organo-Chlorine Compound, Mechanism and Application.” Mizu Kankyo Gakkaishi 20(2) (1997): 68-71.

731. Tanaka, Keiichi, Keiji Abe, and Teruaki Hisanaga. "Photocatalytic Water Treatment on Immobilized $\mathrm{TiO}_{2}$ Combined with Ozonation.” J. Photochem. Photobiol. A 101(1) (1996): 85-87.

732. Tanaka, Keiichi, Puspa Ratu, and Teruaki Hisanaga. "Photocatalytic Degradation of Herbicide Asulam in Aqueous $\mathrm{TiO}_{2}$." Proc. Jpn.-Ger. Workshop Waste Water Sludge Treat., 7th, Tsukuba, Japan: Public Works Research Institute, Water Quality Control Dept. (1998): 420-428.

733. Tanaka, Masanobu, Kazuhiko Mori, and Mitsuru Nakamura. "Coating Film Function of Titanium Dioxide Photocatalytic Coating Agent.” Toso Kogaku 33(9) (1998): 367-370.

734. Tanaka, Yoshimi and Masato Fukunaga. "Photocatalytic Activity of Porous $\mathrm{TiO}_{2} \mathrm{Ceramics}$ Prepared by Sol-Gel Method.” Aichi-Ken Kogyo Gijutsu Senta Kenkyu Hokoku 33 (1997): 1-5.

735. Tang, W.Z., Z. Zhang, H. An, M.O. Quintana, and D.F. Torres. " $\mathrm{TiO}_{2} / \mathrm{UV}$ Photodegradation of Azo Dyes in Aqueous Solutions.” Environ. Technol. 18(1) (1997): 1-12.

736. Tanizaki, Teiji, Kiwao Kadokami, Shinoroku Sugishima, and Manabu Suzuki. "Study on Degradation of Trihalomethanes in Water with Photocatalysts Coated with Titanium Dioxide." Zenkoku Kogaiken Kaishi 22(3) (1997): 104-108.

737. Tao, Yuewu, Mengyue Zhao, Shifu Chen, and Xin Liang. "Photocatalytic Removal of Hazardous Materials from Air." Cuihua Xuebao 18(4) (1997): 345-347.

738. Taoda, Hiroshi. "Titanium Dioxide Photocatalyst Type Antimicrobial Agent.” Shikizai Kyokaishi 71(2) (1998): 113-120.

739. Tennakone, K., C.T.K. Tilakaratne, and I.R.M. Kotegoda. "Photomineralization of Carbofuran by $\mathrm{TiO}_{2}$-Supported Catalyst.” Water Res. 31(8) (1997): 1909-1912.

740. Tennakone, K. and K.G.U. Wijayantha. "Heavy-Metal Extraction from Aqueous Medium with an Immobilized $\mathrm{TiO}_{2}$ Photocatalyst and a Solid Sacrificial Agent." J. Photochem. Photobiol. A 113(1) (1998): 89-92.

741. Theurich, J., D.W. Bahnemann, R. Vogel, F.E. Ehamed, G. Alhakimi, and I. Rajab. "Photo- catalytic Degradation of Naphthalene and Anthracene: GC-MS Analysis of the Degradation Pathway." Res. Chem. Intermed. 23(3) (1997): 247-274. 
742. Theurich, J., M. Lindner, and D.W. Bahnemann. "Photocatalytic Degradation of 4-Chlorophenol in Aerated Aqueous Titanium Dioxide Suspensions: A Kinetic and Mechanistic Study." Langmuir 12(26) (1996): 6368-6376.

743. Thomas, Vernard Ray, Jr. Photocatalytic and Excimer Laser Photolytic Studies of the Environmentally Hazardous Compound 4-Chlorophenol. Ph.D. diss., North Carolina State Univ. (1996).

744. Thornton, Hilary M., G. Lee Christensen, and Rominder P.S. Suri. "Investigation of $\mathrm{TiO}_{2}$-Based Photocatalysts for Inactivation of E. coli in Water." Hazard. Ind. Wastes, 29th (1997): 195-204.

745. Thornton, John P. Solar Thermal Technologies in Support of an Urgent National Need Opportunities for the Photon Enhanced Decomposition of Concentrated and Dilute Hazardous Wastes, SERI/SP-250-3359. SERI, Golden, CO, 1988. DE89000840.

746. Thurnauer, Marion C., Tijana Rajh, and David M. Tiede. "Surface Modification of $\mathrm{TiO}_{2}$ : Correlation between Structure, Charge Separation and Reduction Properties." Acta Chem. Scand. 51(5) (1997): 610-618.

747. Tobimatsu, H., W. Mizubayashi, T. Fujii, K. Shibahara, S. Yokoyama, and M. Hirose. "Reliability Evaluation of Ultrathin Gate Oxides Grown on Si Wafers Stored in Clean Stocker with a UV/Photoelectron Source." IEEE Int. Symp. Semicond. Manuf., Conf. Proc., New York, NY: Institute of Electrical and Electronics Engineers (1997): F/5-F/8.

748. Tone, Setsuji, Masahito Taya, and Yasuhiko Horie. "Photosterilization with Titanium Dioxide Immobilized on Activated Carbon Particles.” Kagaku Kogyo 48(11) (1997): 905-910.

749. Torimoto, Tsukasa, Robert J. Fox, III, and Marye Anne Fox. "Photoelectrochemical Doping of $\mathrm{TiO}_{2}$ Particles and the Effect of Charge Carrier Density on the Photocatalytic Activity of Microporous Semiconductor Electrode Films." J. Electrochem. Soc. 143(11) (1996): 3712-3717.

750. Torimoto, Tsukasa, Yasuhiro Okawa, Norihiko Takeda, and Hiroshi Yoneyama. "Effect of Activated Carbon Content in $\mathrm{TiO}_{2}$-Loaded Activated Carbon on Photodegradation Behavior of Dichloromethane." J. Photochem. Photobiol. A 103(1-2) (1997): 153-157.

751. Toyota, Hiroshi. “Application of Titanium Oxide Photocatalyst to Tent Materials." Kogyo Zairyo 46(5) (1998): 110-113.

752. Trillas, Maria, Jose Peral, and Xavier Domenech. "Photocatalyzed Degradation of Phenol, 2,4-Dichlorophenol, Phenoxyacetic Acid and 2,4-Dichlorophenoxyacetic Acid over Supported $\mathrm{TiO}_{2}$ in a Flow System.” J. Chem. Technol. Biotechnol. 67(3) (1996): 237-242.

753. Tsai, Shi-Jane and Soofin Cheng. "Effect of $\mathrm{TiO}_{2}$ Crystalline Structure in Photocatalytic Degradation of Phenolic Contaminants." Catal. Today 33(1-3) (1997): 227-237.

754. Tung, Chen-Ho and Yun-Ming Ying. "Semiconductor Photoinduced Cycloreversion of the Dimer of Methyl 2-Naphthoate.” Chin. J. Chem. 15(3) (1997): 260-264.

755. Turchi, C.T., E.J. Wolfrum, and M. Nimlos. "Cost Estimation for Treating VOCs in an Air Stripper Offgas with Gas-Phase Photocatalysis." Fifth Annual Symposium on Emerging Technologies in Hazardous Waste Management, I\&EC Special Symposium, American Chemical Society, Washington, DC: American Chemical Society (1993).

756. Turchi, Craig S., James F. Klausner, D Yogi Goswami, and Edward Marchand. Field Test Results 
for the Solar Photocatalytic Detoxification of Fuel-Contaminated Groundwater, NREL/TP-4715345. NREL, Golden, CO, 1993.

757. Turchi, Craig Steven. Heterogeneous Photocatalytic Degradation of Organic Water Contaminants: Kinetics and Hydroxyl Radical Mechanisms. Ph.D. diss., North Carolina State Univ. (1990).

758. Tyner, Craig E., James E. Pacheco, C.A. Haslund, and John T. Holmes. Rapid Destruction of Organic Chemicals in Groundwater Using Sunlight. Albuquerque, NM: Sandia National Laboratories (1989): 8 pp.

759. Uchida, Hiroyuki, Shinobu Katoh, and Masahiro Watanabe. "Photocatalytic Degradation of Trichlorobenzene Using Immobilized $\mathrm{TiO}_{2}$ Films Containing Poly(Tetrafluoroethylene) and Platinum Metal Catalyst.” Electrochim. Acta 43(14-15) (1998): 2111-2116.

760. Uenishi, Toshiaki. “Titanium Oxide Photocatalyst Materials, PC Series.” Kogyo Zairyo 45(10) (1997): 48-50.

761. Ullah, S.S., M.G.M. Khan, and A.B.M. Shamsur Rahman. "Photocatalytic Decomposition of Phenols by Titanium Dioxide under Sunlight and UV." J. Bangladesh Acad. Sci. 22(1) (1998): $29-37$.

762. Upadhya, Santosh and David F. Ollis. "A Simple Photocatalysis Model for Photoefficiency Enhancement via Controlled, Periodic Illumination.” J. Phys. Chem. B 101(14) (1997): 2625-2631.

763. Upadhya, Santosh and David F. Ollis. "A Simple Kinetic Model for the Simultaneous Concentration and Intensity Dependencies of TCE Photocatalyzed Destruction." J. Adv. Oxid. Technol. 3(2) (1998): 199-202.

764. Van Well, M., R.H.G. Dillert, D.W. Bahnemann, V.W. Benz, and M.A. Mueller. “A Novel Nonconcentrating Reactor for Solar Water Detoxification.” J. Sol. Energy Eng. 119(2) (1997): 114 119.

765. Vautier-Giongo, Carolina and Ines Joekes. "Deposition of Titanium Dioxide on Brazilian Chrysotile Fibers." Powder Technol. 94(1) (1997): 73-78.

766. Vaz, J.L. Lucas, A. Boussaoud, Y. Ait Ichou, and M. Petit-Ramel. "Photomineralization on Titanium Dioxide of Uracil and 5-Halouracils. Influence of PH and Some Anions on the Photodegradation of Uracil." Analusis 26(2) (1998): 83-87.

767. Vidal, Alfonso. "Developments in Solar Photocatalysis for Water Purification." Chemosphere 36(12) (1998): 2593-2606.

768. Vidal, Alfonso. "Developments in Solar Photocatalysis for Water Purification. [Erratum to Document Cited in CA128:261574]." Chemosphere 37(2) (1998): 387.

769. Vohra, Muhammad S. and Allen P. Davis. "Adsorption of $\mathrm{Pb}(\mathrm{II}), \mathrm{NTA}$, and $\mathrm{Pb}(\mathrm{II})-\mathrm{NTA}$ onto $\mathrm{TiO}_{2}$." J. Colloid Interface Sci. 194(1) (1997): 59-67.

770. Vorontsov, A.V., G.B. Barannik, O.I. Snegurenko, E.N. Savinov, and V.N. Parmon. "Complete Heterogeneous Photocatalytic Oxidation of Acetone, Ethanol, and Diethyl Ether Vapors with Air over Honeycomb-Supported $\mathrm{TiO}_{2}$." Kinet. Catal. (Transl. of Kinet. Katal.) 38(1) (1997): 84-87.

771. Vorontsov, A.V., E.N. Savinov, G.B. Barannik, V.N. Troitsky, and V.N. Parmon. "Quantitative 
Studies on the Heterogeneous Gas-Phase Photooxidation of CO and Simple Volatile Organic Compounds (VOCs) by Air over $\mathrm{TiO}_{2}$." Catal. Today 39(3) (1997): 207-218.

772. Vorontsov, A.V., E.N. Savinov, E.N. Kurkin, O.D. Torbova, and V.N. Parmon. "Kinetic Features of the Steady State Photocatalytic CO Oxidation by Air on $\mathrm{TiO}_{2}$." React. Kinet. Catal. Lett. 62(1) (1997): 83-88.

773. Wamer, Wayne G., Jun-Jie Yin, and Rong Rong Wei. "Oxidative Damage to Nucleic Acids Photosensitized by Titanium Dioxide.” Free Radical Biol. Med. 23(6) (1997): 851-858.

774. Wang, Chauan-yi, Chun-yan Liu, Xuan Zheng, Jin Chen, and Tao Shen. "The Surface Chemistry of Hybrid Nanometer-Sized Particles. I. Photochemical Deposition of Gold on Ultrafine $\mathrm{TiO}_{2}$ Particles." Colloids Surf. A 131(1-3) (1998): 271-280.

775. Wang, Chen-Chi, Zhibo Zhang, and Jackie Y. Ying. "Photocatalytic Decomposition of Halogenated Organics over Nanocrystalline Titania.” Nanostruct. Mater. 9(1-8) (1997): 583-586.

776. Wang, Chuan-yi, Chun-yun Liu, and Tao Shen. "The Photocatalytic Oxidation of Phenylmercaptotetrazole in $\mathrm{TiO}_{2}$ Dispersions." J. Photochem. Photobiol. A 109(1) (1997): 65-70.

777. Wang, Hongyu, Richard E. Partch, and Yuzhuo Li. "Synthesis of 2-Alkylbenzimidazoles via $\mathrm{TiO}_{2}$ Mediated Photocatalysis.” J. Org. Chem. 62(15) (1997): 5222-5225.

778. Wang, Kuo-hua and Yung-hsu Hsieh. "Heterogeneous Photocatalytic Degradation of Trichloroethylene in Vapor Phase by Titanium Dioxide." Environ. Int. 24(3) (1998): 267-274.

779. Wang, Kuo-hua, Yung-hsu Hsieh, and Lih-jinn Chen. "The Heterogeneous Photocatalytic Degradation, Intermediates and Mineralization for the Aqueous Solution of Cresols and Nitrophenols." J. Hazard. Mater. 59(2-3) (1998): 251-260.

780. Wang, Kuo-hua, Huan-hung Tsai, and Yung-hsu Hsieh. "A Study of Photocatalytic Degra- dation of Trichloroethylene in Vapor Phase on $\mathrm{TiO}_{2}$ Photocatalyst." Chemosphere 36(13) (1998): 2763-2773.

781. Wang, Kuo-Hua, Hung-Huan Tsai, and Yung-Hsu Hsieh. "The Kinetics of Photocatalytic Degradation of Trichloroethylene in Gas Phase over $\mathrm{TiO}_{2}$ Supported on Glass Bead." Appl. Catal. B 17(4) (1998): 313-320.

782. Wang, Rong, Kazuhito Hashimoto, Akira Fujishima, Makoto Chikuni, Eiichi Kojima, Atsushi Kitamura, Mitsuhide Shimohigoshi, and Toshiya Watanabe. "Light Induced Amphiphilic Surfaces." Nature 388 (1997): 431-432.

783. Wang, S., B. Raman, D.H. Chen, K.Y. Li, and J.A. Colapret. "Photocatalytic Oxidation of $\mathrm{NO}_{\mathrm{x}}$ Using $\mathrm{TiO}_{2}$ and Adsorbents." Chem. Oxid 1995 (1997): 5289-5302.

784. Wang, Yi-zhong, Yuan Fu, and Hong-xiao Tang. "Comparative Study of Performance Efficiency for Three Kinds of Photoreactors.” J. Environ. Sci. 10(3) (1998): 291-295.

785. Wang, Yizhong and Yan Fu. "Solar Photocatalytic Degradation of Different Types of Dyes." Taiyangneng Xuebao 19(2) (1998): 117-126.

786. Wang, Yizhong, Yan Fu, and Hongxiao Tang. "Photocatalytic Degradation of Methyl Orange in $\mathrm{TiO}_{2}$ Suspension.” Huanjing Kexue 19(1) (1998): 1-4. 
787. Wang, Yizhong and Yuan Fu. "Comparative Study on Performance Efficiency Using Lamp Light and Solar Light in Photocatalytic Degradation Process." Taiyangneng Xuebao 19(1) (1998): 36-40.

788. Wang, Yizhong and Chun Hu. "Preparation of Fixed Catalyst of $\mathrm{TiO}_{2}$ for Photocatalytic Degradation of Organics." Huanjing Kexue 19(4) (1998): 40-42.

789. Wang, Yizhong, Chun Hu, and Hongxiao Tang. "Study on Phenol Photocatalytic Oxidation on $\mathrm{TiO}_{2}$ Catalyst. 2. Comparison between Heterogeneous Photocatalytic Oxidation and Direct Photolysis of Phenol in Aqueous Solution." Huanjing Kexue Xuebao 18(3) (1998): 260-264.

790. Wang, Youping, Jiaguo Yu, Xiujian Zhao, and Zhuming Shi. "Preparation of Nanometer Pb-Doped $\mathrm{TiO}_{2}$ Thin Film by Sol-Gel Processing and Its Photocatalytic Properties." Zhongguo Huanjing Kexue 18(3) (1998): 244-247.

791. Watanabe, Eiji, Hiroshi Taoda, Kazumi Kato, Toru Nonami, Kozo Iseda, and Mitsuharu Fukaya. "Water Purification by Titanium Dioxide Thin Film Photocatalyst." Nagoya Kogyo Gijutsu Kenkyusho Hokoku 46(4) (1997): 227-238.

792. Watanabe, Mitsuru. " $\mathrm{TiO}_{2}$ Photocatalysts as Materials for Creation of a Pleasant Environment Recent Application Technology.” Kagaku Kogaku 62(6) (1998): 331-332.

793. Watanabe, Toshiya. "Purification of Environment by Light. Environmental Purification by Titanium Oxide Photocatalysts.” Kagaku to Kyoiku 46(12) (1998): 772-777.

794. Wei, Hongbin, Dimin Xu, and Jianwei Xu. "Photooxidation of Humic Acid in Aqueous Solution Catalized by $\mathrm{TiO}_{2}$ Film.” Huanjing Kexue Xuebao 18(2) (1998): 161-166.

795. Wei, Hongbin, Xushi Yan, and Dinin Xu. "Advanced Treatment of Tap Water by Immobilized Photocatalytic Oxidation with Titanium Dioxide Film.” Zhongguo Jishui Paishui 12(6) (1996): 1013.

796. Weiger, Roland and Norbert Engel. "Die Denta-Solar ein Vergleich mit einer Herkommlichen Zahnburste [Denta-Solar-Comparison with a Traditional Toothbrush]." Oralprophylaxe (AP7) 13(1) (1991): 32-36.

797. Wendelin, Tim. "A Survey of Potential Low-Cost Concentrator Concepts for Use in LowTemperature Water Detoxification." ASME International Solar Energy Conference, eds. William B. Stine, Jan Kreider, and Koichi Watanabe, New York, NY: ASME (1992): 15-20.

798. Winterbottom, J.M., Z. Khan, A.P. Boyes, and S. Raymahasay. "Photocatalyzed Oxidation of Phenol in Water Using a Cocurrent Downflow Contactor Reactor (CDCR)." Environ. Prog. 16(2) (1997): $125-131$.

799. Wittenberg, R., M.A. Pradera, and J.A. Navio. "Cumene Photo-Oxidation over Powder $\mathrm{TiO}_{2}$ Catalyst." Langmuir 13(8) (1997): 2373-2379.

800. Wold, Aaron, Y.M. Gao, Daniel Miller, Robert Kershaw, and Kirby Dwight. "Synthesis of Catalytic Materials by Spray Pyrolysis." Adv. Catal. Nanostruct. Mater., San Diego, CA: Academic Press (1996): 505-514.

801. Wolfe, William L. "Properties of Optical Materials." Handbook of Optics, eds. Walter G. Driscoll and William Vaughan, New York, NY: McGraw-Hill Book Company (1978): 7-1-157. 
802. Wolff, Kirsten, Dirk Bockelmann, and Detlef W. Bahnemann. "Mechanistic Assets of Chemical Transformations in Photocatalytic Systems." Symp. Electron. Ionic Prop. Silver Halides, ed. Boris Levy, Springfield, VA: IS\&T (1991): 259-267.

803. Wu, Chang Yu, Tai-Gyu Lee, Glendon Tyree, Elizabeth Arar, and Pratim Biswas. "Capture of Mercury in Combustion Systems by In Situ-Generated Titania Particles with UV Irradiation." Environ. Eng. Sci. 15(2) (1998): 137-148.

804. Wu, Haibao and Xiaolai Dong. "Solar Energy- $\mathrm{TiO}_{2}$ Heterogeneous Photocatalytic Oxidation for Decolorization of Dying Wastewater.” Zhongguo Huanjing Kexue 17(1) (1997): 93-96.

805. Wu, Haibao and Xiaolai Dong. "Study on Solar Photocatalysis Decolorization of Dye Effluent." Taiyangneng Xuebao 18(4) (1997): 380-384.

806. Wu, Haibo. "Mechanism for Photocatalytic Oxidation of Organism in Semiconductor-Water System.” Huanjing Wuran Yu Fangzhi 18(2) (1996): 40-43.

807. Wu, Xing-Zheng, Takashi Nakayama, Katsumi Uchiyama, and Toshiyuki Hobo. "Time-Resolved Chemiluminescence Measurements for Photoinitiated Chemiluminescence Reactions." Nippon Kagaku Kaishi 12 (1997): 899-901.

808. Wu, Zhenghuang, Fang Tian, Zhao Junfu, Wengyi Li, and Yongxia Guo. "Photocatalytic $\mathrm{TiO}_{2}$ Thin Film for Treatment of Phenol Solution." Taiyuan Ligong Daxue Xuebao 29(3) (1998): $247-249$.

809. Wu, Zhenghuang, Junfu Zhao, Zhengbang Wu, and Wenyi Li. "Photocatalytic $\mathrm{TiO}_{2}$ Film for Treating Phenol Solution.” Taiyuan Ligong Daxue Xuebao 29(4) (1998): 354-355.

810. $\mathrm{Xu}$, Chihuan. "Application of Catalytic Reaction of $\mathrm{TiO}_{2}$ under Faint Light in Japan." Xiandai Huagong 18(5) (1998): 17-19.

811. Xu, Yiming. Photocatalysis of Supported Titania on Micro/Mesoporous Zeolites for the Oxidation of Organic Compounds in Water. Ph.D. diss., Univ. of Calgary (1997).

812. Xu, Yiming and Cooper H. Langford. "A Comparison of Acetophenone Photooxidation in Aqueous Media via Direct Photolysis and $\mathrm{TiO}_{2}$ Photocatalysis." J. Adv. Oxid. Technol. 2(3) (1997): 408-414.

813. Xu, Yiming and Cooper H. Langford. "Photoactivity of Titanium Dioxide Supported on MCM41, Zeolite X, and Zeolite Y.” J. Phys. Chem. B 101(16) (1997): 3115-3121.

814. Yamaguchi, Fumio and Nobuyuki Koura. "Sterilization under $\mathrm{TiO}_{2}$ Photocatalyst of Electro Composite Deposition Ni-TiO 2. " Hyomen Gijutsu 49(7) (1998): 788-789.

815. Yamaguchi, Tomohiro, Koji Hoshi, Masayoshi Fukazawa, and Toru Kuno. "Development of Ceramics for Removing Pollutants from Environment. Part I. Removal of $\mathrm{NOx}$ by $\mathrm{TiO}_{2}$ Photocatalysts Anchored on Tiles." Aichi-Ken Tokoname Yogyo Gijutsu Senta Hokoku 23 (1996): $7-11$.

816. Yamamoto, Katsumi. “Titanium Oxide Photocatalyst Materials.” Kogyo Zairyo 45(10) (1997): $42-44$.

817. Yamamoto, Shin. “Titanium Oxide Photocatalyst Materials, Tinock.” Kogyo Zairyo 45(10) (1997): 
$51-53$.

818. Yamashita, Hiromi, Yuichi Ichihashi, Masakazu Anpo, Mitsuo Hashimoto, Catherine Louis, and Michel Che. "Photocatalytic Decomposition of NO at $275 \mathrm{~K}$ on Titanium Oxides Included within YZeolites Cavities: The Structure and Role of the Active Sites." J. Phys. Chem. 100(40) (1996): 16041-16044.

819. Yamashita, Hiromi, Yuichi Ichihashi, Shu Guo Zhang, Yasuyuki Matsumura, Yoshie Souma, Takashi Tatsumi, and Masakazu Anpo. "Photocatalytic Decomposition of NO at $275 \mathrm{~K}$ on Titanium Oxide Catalysts Anchored within Zeolite Cavities and Framework.” Appl. Surf. Sci. 121-122 (1997): 305-309.

820. Yamashita, Hiromi, Shinichi Kawasaki, Yuichi Ichihashi, Masaru Harada, Masato Takeuchi, Masakazu Anpo, Gina Stewart, Marye Anne Fox, Catherine Louis, and Michel Che. "Characterization of Titanium-Silicon Binary Oxide Catalysts Prepared by the Sol-Gel Method and Their Photocatalytic Reactivity for the Liquid-Phase Oxidation of 1-Octanol." J. Phys. Chem. B 102(30) (1998): 5870-5875.

821. Yamashita, Mitsugi, Masao Ando, and Masako Sakai. "Use of Titanium Oxide Photocatalyst for Air Cleaning." Kogyo Zairyo 46(5) (1998): 114-117.

822. Yamazaki-Nishida, Suzuko, Xianzhi Fu, Marc A. Anderson, and Kenzi Hori. "Chlorinated Byproducts from the Photoassisted Catalytic Oxidation of Trichloroethylene and Tetrachloroethylene in the Gas Phase Using Porous $\mathrm{TiO}_{2}$ Pellets." J. Photochem. Photobiol. A 97(3) (1996): $175-179$.

823. Yang, J.C., Y.C. Kim, Y.G. Shul, C.H. Shin, and T.K. Lee. "Characterization of Photoreduced $\mathrm{Pt} / \mathrm{TiO}_{2}$ and Decomposition of Dichloroacetic Acid over Photoreduced $\mathrm{Pt} / \mathrm{TiO}_{2}$ Catalysts." Appl. Surf. Sci. 121-122 (1997): 525-529.

824. Yang, Qing. "Effect of Gelling Method on Structure and Reactivity of Titania Photocatalyst." Fuzhou Daxue Xuebao, Ziran Kexueban 25(6) (1997): 108-111.

825. Yang, Shuijin. "Photocatalytic Degradation of Active Chlorine Dye Wastewater with Tungsten Compounds and $\mathrm{TiO}_{2}$." Baoji Wenli Xueyuan Xuebao, Ziran Kexueban 17(1) (1997): 25-27.

826. Yasunaga, Tatsuya. "Development of Antibacterial Titanium Materials.” Kinzoku 67(10) (1997): $870-873$.

827. Yoneyama, Hiroshi. "Photoreduction of Carbon Dioxide on Quantized Semiconductor Nanoparticles in Solution." Catal. Today 39(3) (1997): 169-175.

828. Yoneyama, Hiroshi, Tsukasa Torimoto, Naoko Iwata, and Hiroshi Kanemoto. "Photocatalytic Detoxification of Organic Pollutants Dissolved in Aqueous Solutions Using Titanium DioxideLoaded Carbon Black as a Photocatalyst." Proc. Electrochem. Soc. 98-5, Environmental Issues in the Electronics/Semiconductor Industries and Electrochemical/Photochemical Methods for Pollution Abatement (1998): 188-192.

829. Yoshida, Katsuhiko, Kazuo Okamura, Kiminori Itoh, and Masayuki Murabayashi. "Photocata- lytic Degradation of Chlorinated Compounds in Water. Effect of the Number of the Repeated DipCoating for the $\mathrm{TiO}_{2}$ Thin-Film on the Degradation of TCE." Denki Kagaku Oyobi Kogyo Butsuri Kagaku 66(2) (1998): 171-175. 
830. Yoshida, Masanao, Shigeo Sugiuchi, Kaoru Okawara, and Shunichi Ohori. "Metal Plating Wastewater Treatment Using Photocatalyst. Synthesis of $\mathrm{TiO}_{2}$ Anatase by Sol-Gel Process." Shiken Kenkyu Hokoku, Fukushima-Ken Haiteku Puraza 1996 (1997): 101-103.

831. Yoshida, S., S. Takenaka, T. Tanaka, and T. Funabiki. "Ultrahighly Dispersed Titanium Oxide on Silica: Effect of Precursors on the Structure and Photocatalysis." J. Phys. IV 7(C2), X-Ray Absorption Fine Structure, vol. 2 (1997): 859-861.

832. Yoshida, S., S. Takenaka, T. Tanaka, H. Hirano, and H. Hayashi. "Highly Dispersed Titanium Oxide on Silica: Preparation, Characterization by XAFS, and Photocatalysis." Stud. Surf. Sci. Catal. 101, Pt. B, 11th International Congress on Catalysis - 40th Anniversary, 1996, Pt. B (1996): 871-880.

833. Yoshida, Satohiro. "XAFS of Photocatalysts Comprized of Highly Dispersed Metal Oxides on Supports.” Hyomen Kagaku 18(1) (1997): 21-28.

834. Yoshimoto, Tetsuo. "Immobilization of Photocatalysts on Substrate Surface." Kogyo Zairyo 45(10) (1997): 62-66.

835. Yoshioka, Ken, Yoshiyuki Fukazawa, and Isamu Ono. "Preparation and Evaluation on Photocatalytic Activity of Ultra Fine Particle $\mathrm{TiO}_{2}$." Kenkyu Hokoku - Kanagawa-Ken Sangyo Gijutsu Sogo Kenkyusho 2 (1996): 69-70.

836. Yu, Gang, Wanpeng Zhu, Zhihua Yang, and Zhonghe Li. "Semiconductor Photocatalytic Oxidation of H-Acid Aqueous Solution.” Chemosphere 36(12) (1998): 2673-2681.

837. Yu, Jimmy C., Linda Y.L. Chan, and Paul Krause. "Photocatalytic Degradation of a Gaseous Organic Pollutant.” J. Chem. Educ. 75(6) (1998): 750-751.

838. Yu, Jimmy C., Jun Lin, and Raymund W.M. Kwok. "Enhanced Photocatalytic Activity of $\mathrm{Ti}_{1-\mathrm{x}} \mathrm{V}_{\mathrm{x}} \mathrm{O}_{2}$ Solid Solution on the Degradation of Acetone." J. Photochem. Photobiol. A 111(1-3) (1997): 199-203.

839. Yu, Jimmy C., Jun Lin, and Raymund W.M. Kwok. " $\mathrm{Ti}_{1-\mathrm{x}} \mathrm{Zr}_{\mathrm{x}} \mathrm{O}_{2}$ Solid Solutions for the Photocatalytic Degradation of Acetone in Air." J. Phys. Chem. B 102(26) (1998): 5094-5098.

840. Yui, Hiroshi. "Higher Performance and Functions Obtained by Compounding Additives." Purasuchikkusu Eji 44(8) (1998): 117-122.

841. Zen, Hideki. "Manufacture of Fumed Titania P25 and Its Application As Photocatalysts." JETI 46(10) (1998): 66-67.

842. Zhan, Haoqiang, Kongchang Chen, and He Tian. "Photocatalytic Degradation of Acid Azo Dyes in Aqueous $\mathrm{TiO}_{2}$ Suspension II. The Effect of PH Values.” Dyes Pigm. 37(3) (1998): 241-247.

843. Zhan, Haoqiang and He Tian. "Photocatalytic Degradation of Acid Azo Dyes in $\mathrm{TiO}_{2}$ Colloidal Suspension III. Spectral Characterization of Excited State.” Dyes Pigm. 37(3) (1998): 249-254.

844. Zhang, Fenglei, Jincai Zhao, Tao Shen, Hisao Hidaka, Ezio Pelizzetti, and Nick Serpone. "TiO Assisted Photodegradation of Dye Pollutants. II. Adsorption and Degradation Kinetics of Eosin in $\mathrm{TiO}_{2}$ Dispersions under Visible Light Irradiation.” Appl. Catal. B 15(1-2) (1998): 147-156.

845. Zhang, Man-Ping, Run Zhan, Zong-Feng Xia, and Gary Low. "Kinetic Study on the Photocata- lytic Degradation of Methomyl.” Gaodeng Xиехiao Hиахие Xuebao 19(9) (1998): 1475-1478. 
846. Zhang, Pengchu, Ronald J. Scrudato, and G. Germano. "Solarcatalytic Inactivation of E. coli in Aqueous Solutions Using $\mathrm{TiO}_{2}$ as Catalyst.” Chemosphere 28(3) (1994): 607-611.

847. Zhang, Shicheng, Nobuyuki Fujii, and Yoshio Nosaka. "The Dispersion Effect of $\mathrm{TiO}_{2}$ Loaded Over ZSM-5 Zeolite.” J. Mol. Catal. A: Chem. 129(2-3) (1998): 219-224.

848. Zhao, Jincai, Kaiqun Wu, Taixing Wu, Hisao Hidaka, and Nick Serpone. "Photodegradation of Dyes with Poor Solubility in an Aqueous Surfactant $/ \mathrm{TiO}_{2}$ Dispersion under Visible Light Irradiation." $J$. Chem. Soc., Faraday Trans. 94(5) (1998): 673-676.

849. Zhao, Jincai, Taixing Wu, Kaiqun Wu, Kyoko Oikawa, Hisao Hidaka, and Nick Serpone. "Photoassisted Degradation of Dye Pollutants. 3. Degradation of the Cationic Dye Rhodamine B in Aqueous Anionic Surfactant $/ \mathrm{TiO}_{2}$ Dispersions under Visible Light Irradiation: Evidence for the Need of Substrate Adsorption on $\mathrm{TiO}_{2}$ Particles." Environ. Sci. Technol. 32(16) (1998): 2394-2400.

850. Zhao, Jincai, Fenglei Zhang, and Hisao Hidaka. "Study on the Mechanism of the Photodegra- dation of Surfactants Catalyzed by $\mathrm{TiO}_{2}$ Particles." Ganguang Kexue Yu Guang Huaxue 14(3) (1996): 269-273.

851. Zhao, Wenkuan, Youling Fang, Qinghua Dong, and Yizhong Wang. "Preparation of HighPhotocatalytic-Activity Nano-Crystalline Titanium Dioxide by High Temperature ThermoHydrolysis Method." Wuli Huaxue Xuebao 14(5) (1998): 424-428.

852. Zhao, Xiufeng, Xiaodong Sun, Guibin Zhang, Fengshan Shi, and Li Wang. "Photocatalytic Reaction of $\mathrm{NO}_{2}^{-}$Ion." Yingyong Huaxue 15(4) (1998): 25-28.

853. Zhao, Yuguang, Baozhen Wang, Xangzhong Li, and Meisheng Nie. "Treatment of Dyeing Wastewater by a Bio-Photoreactor." Huanjing Kexue Xuebao 18(4) (1998): 373-379. 
854. Zhi, Zhengliang and Xin Wang. "Photo-Catalytic Degradation of Organic Pollutants in Environment by Using Semiconductor as Heterogeneous Catalyst." Huanjing Wuran Yu Fangzhi 20(1) (1998): $42-44$.

855. Zhou, Zufei, Weichuan Jiang, and Weiping Liu. "Photolysis of Alpha-Naphthalene Acetic Acid in Aqueous Solution." Huanjing Kexue 18(1) (1997): 35-37.

856. Zhu, Wanpeng, Li Wang, Zhihua Yang, and Gang Yu. "Photocatalytic Oxidation of H-Acid in Aqueous Solution.” Huanjing Kexue 17(4) (1996): 7-10.

857. Ziolli, Roberta Lourenco, and Wilson F. Jardim. "Mechanism of Photodegradation of Organic Compounds Catalyzed by $\mathrm{TiO}_{2}$." Quim. Nova 21(3) (1998): 319-325. 


\subsection{Patents}

1. Aido, Yuzo, inventor. "Manufacture of Ceramic Products with Photooxidation Catalyst Layer." Teijin Ltd., Japan, assignee. Japan Patent 10152368. 9 June 1998. 129:31306 CA.

2. Aikyo, Hiroyuki and Mitsuo Suzuki, inventors. "Activated Carbon Showing Photocatalytic Activity under Visible Light.” Mitsubishi Chemical Industries Ltd., Japan, assignee. Japan Patent 10226509. 25 August 1998. 129:204849 CA.

3. Aizawa, Kazunori, inventor. "Manufacture of Light-Colored Anionic Surfactants." Kao Corp., Japan, assignee. Japan Patent 10168053. 23 June 1998. 129:137637 CA.

4. Akada, Katsuki, inventor. "Methacrylic Resin Plates for Illuminations or Decorations with Stain Resistance.” Sumitomo Chemical Co., Ltd., Japan, assignee. Japan Patent 09225300. 2 September 1997. 127:263925 CA.

5. Akada, Katsuki, inventor. "Translucent Photocatalysts for Air Purification.” Sumitomo Chemical Co., Ltd., Japan, assignee. Japan Patent 09299808. 25 November 1997. 128:16054 CA.

6. Akada, Katsumi, inventor. "Photocatalysis Coating Compositions and Photocatalysis Media." Sumitomo Chemical Co., Ltd., Japan, assignee. Japan Patent 10176140. 30 June 1998. 129:137351 $C A$.

7. Akagawa, Masatoshi, inventor. "Decorative Sheet Containing Photocatalyst for Permanent Deodorant and Mildew-Proof Effect and Manufacture Thereof." Achilles Corp., Japan, assignee. Japan Patent 10217383. 18 August 1998. 129:190235 CA.

8. Akata, Katsuki, inventor. "Laminated Glasses for Soundproof Plates." Sumitomo Chemical Co., Ltd., Japan, assignee. Japan Patent 09208273. 12 August 1997. 127:251965 CA.

9. Akata, Katsuki, inventor. "Methacrylic Resin Boards Coated by Photocatalysts for Sanitary Goods." Sumitomo Chemical Co., Ltd., Japan, assignee. Japan Patent 09207263. 12 August 1997. 127:222045 CA.

10. Akata, Katsuki, inventor. "Pollutant-Proof Signs.” Sumitomo Chemical Co., Ltd., Japan, assignee. Japan Patent 09209319. 12 August 1997. 127:236118 CA.

11. Akata, Katsuki, inventor. "Soundproof Boards." Sumitomo Chemical Co., Ltd., Japan, assignee. Japan Patent 09209314. 12 August 1997. 127:236117 CA.

12. Akata, , inventor. "Methacrylic Resin-Based Boards for Water Tanks with Excellent Antifouling Katsuki Property." Sumitomo Chemical Co., Ltd., Japan, assignee. Japan Patent 09227752. 2 September 1997. 127:221769 CA.

13. Amano, Isao, Satoshi Nishikata, and Chiaki Nishimura, inventors. "Harmful Gas Removing Apparatus Employing Photolysis Catalyst.” Fuji Electric Co., Ltd., Japan, assignee. Japan Patent 10305213. 17 November 1998. 129:334818 CA.

14. Ando, Masao, Ryoichi Yamanouchi, and Hideto Miyazaki, inventors. "Air Conditioning Apparatus for Automobile.” Echos Research K.K., Japan, assignee. Japan Patent 09309326. 2 December 1997. 128:79201 CA.

15. Ando, Masao, Ryoichi Yamanouchi, Hideto Miyazaki, and Masako Sakai, inventors. "Method and 
Apparatus for Purifying Air Including Adsorbent Reactivation.” Kabushiki Kaisha Equos Research, Japan, assignee. Eur. Pat. Appl. Patent 798143. 1 October 1997. 127:310864 CA.

16. Anpo, Masakazu, Hiromi Yamashita, Sakunobu Kanai, Kazuhito Sato, and Takanori Fujimoto, inventors. "Photocatalyst, Method of Producing the Photocatalyst, and Photocatalytic Reaction Method.” Petroleum Energy Center, Japan, Masakazu Anpo, Hiromi Yamashita, Sakunobu Kanai, Kazuhito Sato, and Takanori Fujimoto, assignees. World Patent 9726991. A1. 31 July 1997. 127:197686 CA.

17. Aoe, Teruo, Masahiro Kurose, and Hiroaki Okuyama, inventors. "Anatase-Type Titanium Oxide Microparticle Having High Photocatalytic Activity and Its Manufacture.” Teikoku Kako Co., Ltd., Japan, assignee. Japan Patent 10137593. 26 May 1998. 129:21388 CA.

18. Aoki, Naohiko, inventor. “Automatic Ice Maker for Refrigerators.” Sharp Corp., Japan, assignee. Japan Patent 09155369. 17 June 1997. 127:137495 CA.

19. Arai, Nobushige and Kozo Morita, inventors. "Catalyst Films and Their Manufacture of Oil Removal and Deodorization.” Sharp Corp., Japan, and Okitsumo K.K., assignees. Japan Patent 09085100. 31 March 1997. 127:22935 CA.

20. Aramaki, Fujio, inventor. "Water Purifying Tool and Water Purifying Container." JME K.K., Japan, assignee. Japan Patent 10230255. 2 September 1998. 129:179950 CA.

21. Ariga, Toru, inventor. "Photocatalyst Membrane for Air Deodorization." Sharp Corp., Japan, assignee. Japan Patent 10094587. 14 April 1998. 128:298752 CA.

22. Arika, Toru and Hideo Yajima, inventors. "Photocatalysts and Air Conditioners Using Them." Sharp Corp., Japan, assignee. Japan Patent 10249209. 22 September 1998. 129:234953 CA.

23. Asada, Koji, Kazuhiko Yoshida, Isao Kobayashi, and Masatoshi Miyatake, inventors. "Coating Materials for Wall Surfaces and Process Therefor." Shikoku Chemicals Corp., Japan, assignee. Japan Patent 10279830. 20 October 1998. 129:344529 CA.

24. Azechi, Shuichi and Takeo Yoshida, inventors. "Silicone Rubber Compositions for High-Voltage Electric Insulators." Shin-Etsu Chemical Industry Co., Ltd., Japan, assignee. Japan Patent 10245489. 14 September 1998. 129:217804 CA.

25. Azuma, Yoichiro and Shinya Hioki, inventors. "Deodorizing Antibacterial Ink-Jet Printing Paper Forming Lightfast Sharp Images and Their Displays.” Mitsubishi Paper Mills, Ltd., Japan, assignee. Japan Patent 10264508. 6 October 1998. 129:317822 CA.

26. Azuma, Youichiro and Shinya Hioki, inventors. "Interior-Decorative Sheets Showing Antifouling Effects and Partition Fittings for Indoor." Mitsubishi Paper Mills, Ltd., Japan, assignee. Japan Patent 10258473. 29 September 1998. 129:277824 CA.

27. Benz, Volker, Michael Mueller, Detlef Bahnemann, Dirk Weichgrebe, and Manfred Brehm, inventors. "Reactors for Photocatalytic Wastewater Purification with the Use of Multi-Layered Cross-Braced Plates as Solar Elements." Roehm Gmbh, Germany, assignee. Europe Patent 738686 23 October 1996. 126:22567 CA.

28. Boire, Philippe and Xavier Talpaert, inventors. "Glass, Ceramic, and Glass-Ceramic Substrates Provided With a Photocatalytic Coating of at Least Partially Crystallized Titania, and Their Use." 
Saint-Gobain Vitrage, Fr., Philippe Boire, and Xavier Talpaert, assignees. World Patent 9710186. 20 March 1997. 126:296625 CA.

29. Brand, John R., Roger A. Baldwin, and Thomas Ian Brownbridge, inventors. "Durable Pigmentary Titanium Dioxide and Methods of Producing the Same.” Kerr-McGee Chemical Corp., USA, assignee. United States Patent 5730796. 24 March 1998. 128:218414 CA.

30. Butters, Brian E. and Anthony L. Powell, inventors. "Advanced Filtration Technique for Fluid Purification.” Brian E. Can. Butter, and Anthony L. Powell, assignees. United States Patent 5589078. 31 December 1996. 126:79425 CA.

31. Camaioni, Donald M. and Michael A. Lilga, inventors. "Photocatalytic Conversion of Organic Compounds Having CH Bonds to Esters." Battelle Memorial Institute, USA, assignee. United States Patent 5708246. 13 January 1998. 128:116563 CA.

32. Cassar, Luigi and Carmine Pepe, inventors. "Photocatalyst Particle-Containing Hydraulic Binder for Cement Compositions, the Cement Compositions Obtained, Dry Premixes Containing the Photocatalyst Particles, Concrete and Mortar Manufactured with the Premixes, Method for Preserving the Brilliance and Color of the Binder.” Italcementi S.P.A., Italy, Luigi Cassar and Carmine Pepe, assignees. World Patent 9805601. 12 February 1998. 128:144408 CA.

33. Chapel, Vincent, inventor. "Kitchen Hood Equipped with Photocatalyst Cooking Vapor Purifier." Seb Sa, Fr., assignee. France Patent 2739792. A1. 18 April 1997. 127:142723 CA.

34. Chiba, Katsuichi, Yoshiki Kinoshita, Kiminori Atsumi, Akira Inase, and Muneteru Saito, inventors. "Antimicrobial Photocatalytic, Metal-Containing Powder and Its Production Method." Ishihara Sangyo Kaisha, Ltd., Japan, and Ltd. Sangi Co., assignees. Japan Patent 09227319. 2 September 1997. 127:258937 CA.

35. Chopin, Thierry, Dominique Dupuis, Corinne Lehaut, Pascal Chartier, and Xavier Talpaert, inventors. "Substrates, Especially Windows, Provided with an at Least Partially Crystalline TitaniaBased Photocatalytic Coating, and Process and Organic Dispersions for Manufacturing the Coated Substrates." Rhone-Poulenc Chimie, Fr., Saint-Gobain Vitrage, Thierry Chopin, Dominique Dupuis, Corinne Lehaut, Pascal Chartier, and Xavier Talpaert, assignees. World Patent 9710185. A1. 20 March 1997. 126:296624 CA.

36. Chouta, Mitsuyoshi and Makoto Hayakawa, inventors. "Ice- and Snow-Repellent Antennas." Toto Ltd., Japan, assignee. Japan Patent 10163720. 19 June 1998. 129:68933 CA.

37. Chouta, Mitsuyoshi, Makoto Hayakawa, and Shunya Watanabe, inventors. "Photocatalytic Materials with Surface Abrasion Resistance.” Toto Ltd., Japan, assignee. Japan Patent 10028868. 3 February 1998. 128:160930 CA.

38. Chouta, Mitsuyoshi and Shin Hayakawa, inventors. “Antifouling Boards.” Toto Ltd., Japan, assignee. Japan Patent 10119229. 12 May 1998. 129:21387 CA.

39. Cooper, Gerald A. and Matthew A. Ratcliff, inventors. "System for and Method of Decontaminating a Contaminated Fluid by Using Photocatalytic Particles.” Photo-Catalytics, Inc., assignee. International Patent 91/08813. 1991.

40. De Lasa, Hugo and Hadeel Ibrahim, inventors. "Photocatalytic Reactor and Method for Destruction of Organic Air-Borne Pollutants.” The University of Western Ontario, Can., assignee. World Patent 
9846335. 22 October 1998. 129:320183 CA.

41. De Lasa, Hugo I. and Julio Valladares, inventors. "Photocatalytic Reactor and Method of Treating Contaminated Water.” University of Western Ontario, Can., assignee. United States Patent 5683589. 4 November 1997. 128:16238 CA.

42. Disanayaka, Bimsara, Ranjith Divigalpitiya, and David E. Livingstone, inventors. "Bench Top UVActivated Odor Filtration Device.” Minnesota Mining and Mfg. Co., USA, assignee. International Patent 9637281. 28 November 1996. 126:79217 CA.

43. Dobashi, Akihiro, Kanji Kinameri, Hisashi Miyashita, Susumu Sakano, Shinichi Ichikawa, and Yoshinori Furukawa, inventors. "Electric Lamp and Its Production Method." Hitachi, Ltd., Japan, assignee. Japan Patent 10241641. 11 September 1998. 129:267695 CA.

44. Doi, Ryota, Shinichi Ichikawa, and Hiroshi Hida, inventors. "Photoelectrochemical Device for Converting Carbon Dioxide into Methane and Ethylene.” Hitachi Ltd., Japan, and Chikyu Kankyo Sangyo Gijutsu K, assignees. Japan Patent 08296077. 12 November 1996. 126:81260 CA.

45. Doi, Yorio, Takeshi Akagi, Naoya Haruta, and Hiroaki Goto, inventors. "Hydrophilic Coating Compositions Containing Photocatalytic Powders and Having Good Antifouling Properties." Kansai Paint Co., Ltd., Japan, assignee. Japan Patent 10265713. 6 October 1998. 129:317680 CA.

46. Domeki, Reiko, inventor. "Exhaust Gas Purifying Apparatus Using Photolysis Catalyst in Internal Combustion Engines.” Mitsubishi Motors Corp., Japan, assignee. Japan Patent 09287435. 4 November 1997. 128:26326 CA.

47. Domoto, Tadanori, inventor. "Photocatalyst-Containing Pressure-Sensitive Adhesive Sheets with High Sterilizing Activity." Nitto Denko Corp., Japan, assignee. Japan Patent 10001646. 6 January 1998. 128:76336 CA.

48. Domoto, Tadanori, inventor. "Sheet Provided with Function of Decomposing Air Pollutant Gases and Its Production." Nitto Denko Corp., Japan, assignee. Japan Patent 10230134. 2 September 1998. 129:179496 CA.

49. Domoto, Tadanori, Mitsuo Iimura, and Kenji Sato, inventors. "Soiling-Resistant Fluoropolymer Sheets Having the Surface Containing Photocatalyst Fine Particles." Nitto Denko Corp., Japan, assignee. Japan Patent 09316214. 9 December 1997. 128:62624 CA.

50. Domoto, Tadanori, Nobuo Onishi, Akira Torii, Akira Fujishima, and Kazuhito Hashimoto, inventors. "Fluoropolymer-Containing Antifouling Film Materials for Construction Materials and Their Manufacture.” Nitto Denko Corp., Japan, Akira Fujishima, and Kazuhito Hashimoto, assignees. Japan Patent 09207289. 12 August 1997. 127:191727 CA.

51. Ehara, Jo, Kohei Sekine, Morio Inoue, Toshinori Takagi, Shoichi Yasuho, Hiromi Yamashita, and Akira Yoshikawa, inventors. "Photolysis Catalyst for Treating Air and Water and Its Preparation." Ion Kogaku Kenkyusho K.K., Japan, assignee. Japan Patent 10043601. 17 February 1998. 128:196219 CA.

52. Endo, Eiji and Takeshi Morimoto, inventors. "Photocatalyst Composition Containing Silica and Semiconductor Photocatalyst and Its Manufacture.” Asahi Glass Co., Ltd., Japan, assignee. Japan Patent 10085599. 7 April 1998. 128:276991 CA. 
53. Endo, Eiji, Takashige Yoneda, and Takeshi Morimoto, inventors. "Semiconductor Photocatalyst Suitable for Coatings on Glasses and Tiles to Prevent Fouling and Fogging and Its Preparation." Asahi Glass Co., Ltd., Japan, assignee. Japan Patent 10113563. 6 May 1998. 128:315048 CA.

54. Endoh, Eiji and Takeshi Morimoto, inventors. "Photocatalyst Composition and Process for Its Production, and Photocatalyst Composition Attached to a Substrate Such as Glass or Tile for Protection against Air Pollution.” Asahi Glass Company Ltd., Japan, assignee. Europe Patent 780158. A1. 25 June 1997. 127:125724 CA.

55. Engeler, Werner and Dieter Neyer, inventors. "Photocatalyst for Decreasing Carbon Monoxide, Hydrocarbons and Nitrogen Oxides in Exhaust Gases." Volkswagen A.-G., Germany, Werner Engeler, and Dieter Neyer, assignees. World Patent 9748476. 24 December 1997. 128:93664 CA.

56. Engeler, Werner, Dieter Neyer, Martina Kosters, and Diethard Hesse, inventors. "Method and Device for Purifying Cold-Start Exhaust Gases." Volkswagen A.-G., Germany, Werner Engeler, Dieter Neyer, Martina Kosters, and Diethard Hesse, assignees. World Patent 9731705 A2. 4 September 1997. 127:252400 CA.

57. Enoki, Masatoshi and Jun Kimura, inventors. "Shower Head Having Spray Channels Coated with Photolysis Catalysts.” Toto Ltd., Japan, assignee. Japan Patent 10076185. 24 March 1998. 128:248307 CA.

58. Finley, James J. and F. Howard Gillery, inventors. "Method for Depositing a Barrier Film for Alkali Metal Oxide Diffusion Prevention from Glass Substrates for Liquid Crystal Displays and Photochromic and Photocatalytic Devices.” PPG Industries, Inc., USA, assignee. United States Patent 5830252. 3 November 1998. 129:334497 CA.

59. Fleischmann, Thomas, Friedmar Kerbe, Baerbel Voigtsberger, and Willi Friedel Ullrich, inventors. "Integrated Filtration-Photocatalytic Apparatus for Treatment of Liquids Containing Harmful Substances." Tridelta Gmbh, Germany, assignee. Germany Patent 19515828 A1. 31 October 1996. 126:61968 CA.

60. Freihaut, James D., Paul A. Bonczyk, Joseph J. Sangiovanni, and Bernard A. Woody, inventors. "Organic Pollutant Removal System for Rooms and Automobiles." USA United Technologies Corporation, assignee. International Patent 9637280. 28 November 1996.

61. Fujihata, Kenji and Shuji Seki, inventors. "Method and Apparatus for Decomposing Organic Substances in Polluted Water and Wastewater." Toshiba Corp., Japan, assignee. Japan Patent 10263537. 6 October 1998. 129:320891 CA.

62. Fujii, Toshiaki, inventor. "Method for Cleaning Gases with a Photocatalyst." Ebara Corp., Japan, assignee. Europe Patent 769322. A1. 23 April 1997. 126:336784 CA.

63. Fujii, Toshiaki, inventor. "Air Purification Materials and Air Purification Using Them." Ebara Corp., Japan, assignee. Japan Patent 10211419. 11 August 1998. 129:165544 CA.

64. Fujii, Toshiaki, inventor. "Method and Device for Gas Purification in Clean Rooms." Ebara Corp., Japan, assignee. Japan Patent 10296042. 10 November 1998. 130:42601 CA.

65. Fujii, Toshiaki and Hiroaki Tada, inventors. "Removal of Harmful Gases from Air and Its Apparatus.” Ebara Corp., Japan, and Nippon Sheet Glass Techno Research K.K., assignees. Japan Patent 09215910. 19 August 1997. 127:209637 CA. 
66. Fujii, Toshiaki and Hiroaki Tada, inventors. "Method and Device for Removal of Harmful Gases Using Photocatalyst and Electrodes." Ebara Corp., Japan, and Nippon Sheet Glass Techno Research K.K., assignees. Japan Patent 10137547. 26 May 1998. 129:58032 CA.

67. Fujii, Toshiaki and Shoji Yamanaka, inventors. "Method and Material for Air Purification in Clean Room Using UV Irradiation with Photocatalyst.” Ebara Corp., Japan, assignee. Japan Patent 09294919. 18 November 1997. 128:65746 CA.

68. Fujino, Kiyoshi, Eiji Fujimoto, Kazuhiro Kobayashi, Keisuke Hisada, Kentaro Todoroki, Koji Oshima, and Masahiro Miyauchi, inventors. "Deodorization Body and Deodorization Apparatus Using Adsorbent and Photolysis Catalyst.” Toto Ltd., Japan, assignee. Japan Patent 10286436. 27 October 1998. 129:305743 CA.

69. Fujishima, Akira, Kazuhito Hashimoto, Hiroshi Koizumi, Naoki Kanamori, and Katsuhiko Seki, inventors. "Washfast Deodorant Fiber Products Preventing Tobacco Odor Adhesion and Capable of Decomposing Tobacco Stains." Fujishima, Akira, Japan, Kazuhito Hashimoto, and Ltd. Asahi Chemical Industry Co., assignees. Japan Patent 10008376. 13 January 1998. 128:116237 CA.

70. Fujishima, Akira, Kazuhito Hashimoto, Nobuyuki Nakada, and Toshio Arai, inventors. "Antimicrobial-Treated Al or Colored Al Construction Materials and Fabrication Thereof." Fujishima, Akira, Japan, Kazuhito Hashimoto, and Yoshida Kogyo K.K., assignees. Japan Patent 09071897. 19 March 1997. 127:10342 CA.

71. Fujishima, Akira, Kazuhito Hashimoto, Nobuyuki Nakada, and Toshio Arai, inventors. "Antifouling Screen Net Coated with Photocatalytic Film." Fujishima, Akira, Japan, Kazuhito Hashimoto, and Yoshida Kogyo K.K., assignees. Japan Patent 09195647. 29 July 1997. 127:207038 CA.

72. Fujishima, Akira, Kazuhito Hashimoto, Nobuyuki Nakada, and Toshio Arai, inventors. "MildewProof Water- and Air-Tight Construction Materials and Their Manufacture." Fujishima, Akira, Japan, Kazuhito Hashimoto, and YKK K.K., assignees. Japan Patent 09195638. 29 July 1997. 127:177487 CA.

73. Fujishima, Akira, Kazuhito Hashimoto, Nobuyuki Nakada, Toshio Arai, and Norio Nakata, inventors. "Aluminum Alloy Coated with a Photocatalyst Membrane." Fujishima, Akira, Japan, Kazuhito Hashimoto, and Ltd. Y.K.K. Co., assignees. Japan Patent 09279396. 28 October 1997. 127:361671 CA.

74. Fujishima, Akira, Kazuhito Hashimoto, Takatoshi Ogawa, Toshio Saito, Yasuaki Sugizaki, and Yoshimasa Ito, inventors. "Oxidized Titanium or Its Alloy Material with Photocatalytic Activity and Its Manufacture.” Kobe Steel Ltd, Japan, and Takenaka Komuten Co, assignees. Japan Patent 08246192 A2. 24 September 1996. 126:24801 CA.

75. Fujishima, Akira, Kazuhito Hashimoto, Hiroshi Oizumi, Naoki Kanamori, and Tetsuo Yamada, inventors. "Multifunctional Odor-Absorbing Fibers with Good Washfastness and Antibacterial Properties and Their Manufacture." Fujishima, Akira, Japan, Kazuhito Hashimoto and Ltd. Asahi Chemical Industry Co., assignees. Japan Patent 10008327. 13 January 1998. 128:129133 CA.

76. Fujishima, Akira, Kazuhito Hashimoto, Kazunori Saito, Tertsuo Yoshimoto, Shigemichi Miyama, and Noriyoshi Saito, inventors. "Titanium Oxide-Containing Photocatalyst with Good Heat Resistance and Its Manufacture.” Kanagawa Kagaku Gijutsu Academy, Japan, and Ltd. Nippon Soda Co., assignees. Japan Patent 09075748. 25 March 1997. 127:25780 CA. 
77. Fujishima, Akira, Kazuhito Hashimoto, Makoto Takada, Shinichi Kamiyama, and Koichi Matsubara, inventors. "Fixation of Semiconductor Photocatalysts." Fujishima, Akira, Japan, Kazuhito Hashimoto, Kazuhito Hashimoto, Shinichi Kamiyama, Koichi Matsubara, and Ltd. Ishihara Sangyo Kaisha, assignees. Japan Patent 09206602. 12 August 1997. 127:236341 CA.

78. Fujishima, Akira, Kazuhito Hashimoto, Osamu Tawara, and Keiko Tsuda, inventors. "Method for Water Analysis.” Fujishima, Akira, Japan, Kazuhito Hashimoto, and Shimadzu Corp., assignees. Japan Patent 09127005. 16 May 1997. 127:89976 CA.

79. Fujishima, Akira, Kazuhito Hashimoto, Tomokazu Yada, Shigemichi Miyama, Tertsuo Yoshimoto, and Noriyoshi Saito, inventors. "Illumination Lamp." Nippon Soda Co., Ltd., Japan, Kanagawa Kagaku Gijutsu Academy, Akira Fujishima, Kazuhito Hashimoto, and Tomokazu Yada, assignees. Japan Patent 09073879. 18 March 1997. 127:25544 CA.

80. Fujishima, Akira, Kazuhito Hashimoto, Tomokazu Yada, and Yoshihiko Tagawa, inventors. "Manufacturing of Surface Elastic Wave Gas Sensor." Kanagawa Kagaku Gijutsu Academy, Japan, and Yoshihiko Tanaka, assignees. Japan Patent 09243618. 19 September 1997. 127:314223 CA.

81. Fukui, Hideo, Masashi Yamaguchi, and Masayuki Kobayashi, inventors. "Construction Alumi- num Parts Having Antibacterial and Fungicidal Properties.” Wai Kei Kei Kk, Japan, assignee. Japan Patent 08296060. 12 November 1996. 126:107495 CA.

82. Fukunaga, Toshikazu, inventor. "Method for Manufacturing Functional Artificial Admiration Plant Using Photocatalyst for Indoor Air Purification.” Fukuju Corporation Y.K., Japan, assignee. Japan Patent 10292215. 4 November 1998. 130:16926 CA.

83. Fukushima, Kosuke, Hideyuki Matsui, Yukihiro Muroya, and Tatsumi Hamanaka, inventors. "Water Faucet Having Antifouling Surface and Generating No Cavitation-Induced Noise.” Toto Ltd., Japan, assignee. Japan Patent 10046638. 17 February 1998. 128:206068 CA.

84. Funakoshi, Hidetada, Masao Kawahara, Takeshi Kawaji, Yoshimasa Hayashi, Haruka Ogawa, and Kazufusa Mitani, inventors. "Manufacture of Cement Mortar and Concrete Products and Forms for the Process.” Dainichi Seika Kogyo K.K., Japan, Shockbeton Japan K.K., and Ltd. Obayashi Construction Co., assignees. Japan Patent 10296708. 10 November 1998. 129:334624 CA.

85. Furuya, Masahiro and Masaaki Yamaya, inventors. "Water-Thinned Silicone Coating Compositions Having Excellent Dispersion and Storage Stability and Hydrophilic Films and Hydrophilic Film-Coated Articles Using the Same.” Shin-Etsu Chemical Co., Ltd., Japan, assignee. Europe Patent 857770. 12 August 1998. 129:177008 CA.

86. Gokami, Yasutaka, inventor. "Ultraviolet Lamp with Photocatalyst Layer and Lighting Device and Ultraviolet Light-Irradiation Apparatus Using Same.” Toshiba Lighting and Technology Corp., Japan, assignee. Japan Patent 10106490. 24 April 1998. 128:301907 CA.

87. Gonzalez-Martin, Anuncia, Oliver J. Murphy, and Dalibor Hodko, inventors. "Photocatalytic Oxidation of Organics Using a Porous Titanium Dioxide Membrane and an Efficient Oxidant." Lynntech, Inc., USA, assignee. United States Patent 5779912. 14 July 1998. 129:99397 CA.

88. Goto, Nobuyuki and Masaru Ebina, inventors. "Grease Filter Using Photocatalyst and Its Use in Range Hood.” Tokyo Gas Co., Ltd., Japan, assignee. Japan Patent 10174821. 30 June 1998. 129:71434 CA. 
89. Greenberg, Charles B., inventor. "Photocatalytically Activated Self-Cleaning Appliances, Especially Ovens, and Their Manufacture.” PPG Industries, Inc., USA, assignee. World Patent 9841482. 24 September 1998. 129:233849 CA.

90. Greenberg, Charles B., Caroline S. Harris, Vincent Korthuis, Luke A. Kutilek, David E. Singleton, Janos Szanyi, and James P. Thiel, inventors. "Photocatalytically Activated Self-Cleaning Coating on Substrates, Especially Glass, and Method for Their Formation.” PPG Industries, Inc., USA, assignee. World Patent 9841480. 24 September 1998. 129:249109 CA.

91. Haga, Tetsuo, Toshikatsu Mori, Masayoshi Kubota, Koji Kageyama, and Naoto Komatsu, inventors. "Device for Membrane Treatment of Water." Hitachi, Ltd., Japan, assignee. Japan Patent 10296057. 10 November 1998. 129:320549 CA.

92. Hagiwara, Hiroshi, inventor. "Maintenance-Free Apparatus for Air Deodorization in Automo- biles." Kawai Musical Instruments Mfg. Co., Ltd., Japan, assignee. Japan Patent 10244129. 14 September 1998. 129:234918 CA.

93. Hagiwara, Yutaka and Norihiko Myazaki, inventors. "Heaters with Deodorization Functions." Kawai Musical Instr. Mfg. Co., Japan, assignee. Japan Patent 09007737. 10 January 1997. 126:203186 $C A$.

94. Halleux, Jean Marc, Yves Lehmann, and Marc Rouberol, inventors. "Glass Panes Provided with a Single- or Multilayer Film and a Hybrid-Organic, Especially Polymeric, Coating." Saint Gobain Vitrage S.A., Fr., assignee. France Patent 2755126. 30 April 1998. 129:31270 CA.

95. Harie, Shunsaku and Naoteru Ikeda, inventors. "Apparatus and Method for Circulation and Purification of Liquids with Light Irradiation.” Asahi Glass Co., Ltd., Japan, assignee. Japan Patent 09075929. 25 March 1997. 127:20106 CA.

96. Hasegawa, Morihiro, Toshiro Adachi, and Wakahiro Harada, inventors. "Filters Bearing TitaniaBased Photocatalytic Surface Layer for Air Conditioning." Nisshin Steel Co., Ltd., Japan, assignee. Japan Patent 09262419. 7 October 1997. 127:310900 CA.

97. Hasegawa, Morihiro, Yoshihiro Uematsu, Toshiro Adachi, and Wakahiro Harada, inventors. "Cleaning Trough Having Capability of Self-Cleaning." Nisshin Steel Co. Ltd, Japan, assignee. Japan Patent 09038377. 10 February 1997. 126:253724 CA.

98. Hasegawa, Ryoichi and Katsuichi Kaneko, inventors. "Antisoiling and Antifungal Coating Compositions Containing Photocatalyst Having Good Durability and Adhesion to the Substrate." Nippon Kayaku Kk, Japan, assignee. Japan Patent 09040872. 10 February 1997. 126:239699 CA.

99. Hatakeyama, Keiji, Miho Saito, Hisashi Honda, Yuichi Sakakibara, and Akiko Saito, inventors. "Fluorescent Lamp Coated with Photocatalyst for Deodorization Effects." Toshiba Lighting and Technology Corp., Japan, assignee. Japan Patent 09082284. 28 March 1997. 127:25592 CA.

100. Hattori, Takeshi and Shigemichi Murase, inventors. "Spinnerets Coated with Hydrophilic Photocatalyst Thin Films and Melt Spinning of Fibers by Using the Same." Unitika Ltd., Japan, assignee. Japan Patent 10168642. 23 June 1998. 129:68806 CA.

101. Hattori, Takeshi and Shigemichi Murase, inventors. "Spinnerets Coated with Photocatalyst Thin Films and Melt Spinning of Fibers by Using the Same.” Unitika Ltd., Japan, assignee. Japan Patent 10168641. 23 June 1998. 129:68805 CA. 
102. Hattori, Yoshitaka, inventor. "Apparatus for Gas Decomposition by Combined Oxidation and Reduction.” Hattori, Yoshitaka, Japan, and Yasuhiro Suzuki, assignees. Japan Patent 10114504. 6 May 1998. 129:19147 CA.

103. Hayakawa, Makoto, inventor. "Photocatalytic Hydrophilic Antifogging Coating Solutions with Good Long-Term Storability.” Toto Ltd., Japan, assignee. Japan Patent 10195382. 28 July 1998. 129:176990 CA.

104. Hayakawa, Makoto, inventor. "Photocatalytic Hydrophilic Coating Liquids." Toto Ltd., Japan, assignee. Japan Patent 10195379. 28 July 1998. 129:176989 CA.

105. Hayakawa, Makoto, inventor. "Bathtub with Hydrophilic Surface Containing Photolysis Cata- lyst." Toto Ltd., Japan, assignee. Japan Patent 10225393. 25 August 1998. 129:163267 CA.

106. Hayakawa, Makoto, inventor. "Photocatalytic Hydrophilic Material with Good Stain Resistance." Toto Ltd., Japan, assignee. Japan Patent 10235204. 8 September 1998. 129:195740 CA.

107. Hayakawa, Makoto, inventor. "Railroad Vehicles with Prevention of Accident Caused by Ice/ Snow Aggregates.” Toto Ltd., Japan, assignee. Japan Patent 10287239. 27 October 1998. 130:4945 CA.

108. Hayakawa, Makoto, inventor. "Photocatalysts in Roofing Materials for Preventing Attachment of Ice and Snow." Toto Ltd., Japan, assignee. Japan Patent 10292565. 4 November 1998. 129:332591 CA.

109. Hayakawa, Makoto, inventor. "Method to Give Hydrophilic Surfaces Containing Photocatalysts and Ceramic Members Containing Them.” Toto Ltd., Japan, assignee. Japan Patent 10296902. 10 November 1998. 129:346409 CA.

110. Hayakawa, Makoto, Makoto Chikuni, and Eiichi Kojima, inventors. "Method for Removing Pollutants from Air by Using Photocatalysts.” Toto Ltd., Japan, assignee. Japan Patent 09271731. 21 October 1997. 127:350481 CA.

111. Hayakawa, Makoto, Taizo Hamano, Tatsuhiko Kuga, and Yoshimitsu Saeki, inventors. "Photocatalytic Particles for Purification of Water in Aquarium." Toto Ltd, Japan, assignee. Japan Patent 08229408 A2. 10 September 1996. 126:11393 CA.

112. Hayakawa, Makoto, Eiichi Kojima, Keiichiro Norimoto, Mitsuyoshi Machida, Atsushi Kitamura, Toshiya Watanabe, Makoto Chikuni, Akira Fujishima, and Kazuhito Hashimoto, inventors. "Method of Photocatalytically Making the Surface of Base Material Ultrahydrophilic, Base Material Having Ultrahydrophilic and Photocatalytic Surface, and Process for Producing Said Material.” Toto Ltd., Japan, assignee. World Patent 9629375 A1. 26 September 1996. 125:331861 CA.

113. Hayakawa, Makoto, Ryuichi Kojo, and Makoto Sengoku, inventors. "Acrylic-Silicone-Based Photocatalytic Oxide-Containing Hydrophilic Coatings.” Toto Ltd., Japan, assignee. Japan Patent 10067543. 10 March 1998. 128:245258 CA.

114. Hayakawa, Makoto, Ryuichi Koshiro, and Masayoshi Ketayama, inventors. "Removal of Sludge Deposits Containing Hydrophilic Fatty Acid-Series Oils from the Surface of Composite Materials." Toto Ltd., Japan, assignee. Japan Patent, 10286537. 27 October 1998. 130:17002 CA.

115. Hayakawa, Makoto, Tosha Watabe, and Keiichiro Norimoto, inventors. "Surface Parts Having Photocatalyst Layer for Indoor Air Purification.” Toto Ltd, Japan, assignee. Japan Patent 09000939. 
7 January 1997. 126:176050 CA.

116. Hayakawa, Makoto and Shunya Watanabe, inventors. "Air Bubble Adhesion Eliminating Coating and Its Application.” Toto Ltd., Japan, assignee. Japan Patent 09314041. 9 December 1997. 128:90085 CA.

117. Heller, Adam and James R. Brock, inventors. "Materials and Methods for Photocatalyzing Oxidation of Organic Compounds on Water." Board of Regents, the University of Texas System, assignee. United States Patent 5256616. 26 October 1993.

118. Heller, Adam, Yaron Paz, and Yair Haruvy, inventors. "Manufacture of Self-Cleaning Glass, and the Glass Obtained." Adam USA Heller, Yaron Paz, and Yair Haruvy, assignees. International Patent 9707069. 27 February 1997. 126:228543 CA.

119. Heller, Adam, Michael V. Pishko, and Ephraim Heller, inventors. "Photocatalyst-Binder Composition.” E. Heller \& Company, USA, assignee. United States Patent 5616532. A. 1 April 1997. 126:323286 CA.

120. Hioki, Shinya and Yoichiro Azuma, inventors. "Adsorbable Photocatalyst Sheet Including Bacterial Cellulose.” Mitsubishi Paper Mills, Ltd., Japan, assignee. Japan Patent 10263411. 6 October 1998. 129:267821 CA.

121. Hioki, Shinya and Yoichiro Azuma, inventors. "Photocatalyst Sheet Including Bacterial Cellulose with Good Secondary Processability.” Mitsubishi Paper Mills, Ltd., Japan, assignee. Japan Patent 10265586. 6 October 1998. 129:267823 CA.

122. Hirata, Nami, Motohiro Okazaki, and Tadahiro Uemura, inventors. "Sink Wastewater Treatment Process and System.” Toray Industries, Inc., Japan, assignee. Japan Patent 09131588. 20 May 1997. 127:85406 CA.

123. Hirata, Nami, Motohiro Okazaki, and Tadahiro Uemura, inventors. "Thin-Film Photocatalyst and Its Manufacture by Physical Vapor Deposition.” Toray Industries, Inc., Japan, assignee. Japan Patent 09192498. 29 July 1997. 127:142727 CA.

124. Hirayama, Shoji, inventor. "Antiseptic System for Clean Rooms.” Hirayama Setsubi K.K., Japan, assignee. Germany Patent 19505051 A1. 22 August 1996. 125:240848 CA.

125. Hirayama, Shoji, inventor. "Clean Room with Antiseptic Wall Panels and Air Conditioning System Comprising a Photocatalyst.” Hirayama Setsubi Kabushiki Kaisha, Japan, assignee. Great Britain Patent 2298149 A1. 28 August 1996. 125:285048 CA.

126. Hirohata, Osamu, inventor. "Furnitures Containing Photocatalyst for Deodorization and Sterilization.” Sharp Corp., Japan, assignee. Japan Patent 09206136. 12 August 1997. 127:180364 $C A$.

127. Honda, Hisashi and Ariyoshi Ishizaki, inventors. "Illumination Apparatus." Toshiba Lighting and Technology Corp., Japan, assignee. Japan Patent 09251804. 22 September 1997. 127:295059 CA.

128. Honda, Hisashi and Ariyoshi Ishizaki, inventors. "Illumination Apparatus." Toshiba Lighting and Technology Corp., Japan, assignee. Japan Patent 09251803. 22 September 1997. 127:295058 CA.

129. Honda, Hisashi and Hiroshi Kamata, inventors. "Photocatalysts, Light Bulbs, Electric Discharging 
Lamps, and Lighting Fixtures.” Toshiba Lighting \& Technology, Japan, assignee. Japan Patent 09057113. 4 March 1997. 126:282089 CA.

130. Honda, Hisashi and Tsutomu Watanabe, inventors. "Supported Photocatalyst Containing Oxide Particles for Photolysis and Lamp and Lighting Having the Catalyst." Toshiba Lighting and Technology Corp., Japan, assignee. Japan Patent 09262483. 7 October 1997. 127:350486 CA.

131. Honda, Kyuji, Hiroshi Kamata, Chikara Watanabe, and Kazuhiro Sano, inventors. "Photocata- lysts, Light Source, and Lighting Apparatus." Toshiba Lighting and Technology Corp., Japan, and Ltd. Toshiba Glass Co., assignees. Japan Patent 09313588. 9 December 1997. 128:52489 CA.

132. Honda, Nobuyuki, inventor. "Dental Coatings for Controlling Plaque-Related Dental Caries and Periodontal Disease.” Advance K.K., Japan, assignee. Japan Patent 09175923. 8 July 1997. 127:181196 CA.

133. Honta, Kyuji and Ariyoshi Ishisaki, inventors. "Illumination Apparatus." Toshiba Lighting and Technology Corp., Japan, assignee. Japan Patent 10021716. 23 January 1998. 128:173937 CA.

134. Hori, Koji, Masato Kakumoto, Masayoshi Maeda, and Yasuji Miki, inventors. "Inorganic Oxide Composites for Air Deodorization and Their Manufacture.” Miki Riken Kogyo K.K., Japan, assignee. Japan Patent 10033988. 10 February 1998. 128:171528 CA.

135. Hoshi, Koji, Hiroki Namiki, and Susumu Sasabara, inventors. "System of Air Purification and Sound Absorption Used in Road Way." Aichi Prefecture, Japan, and Shinei Kiko K.K., assignees. Japan Patent 10249167. 22 September 1998. 129:280339 CA.

136. Ibusuki, Akitsugu, Hiroshi Takeuchi, Satoshi Nishikata, Masahiro Miyamoto, Kazuteru Aragai, Setsuo Yamada, and Takeo Takahashi, inventors. "Apparatus for Removal of Air Pollutants." Agency of Industrial Sciences and Technology, Japan, and Ltd. Fuji Electric Co., assignees. Japan Patent 09234344. 9 September 1997. 127:282749 CA.

137. Ibusuki, Takatsugu, Hiroshi Takeuchi, Nobuaki Negishi, Kazunobu Ota, Takahiro Doi, and Satoru Tachika, inventors. "Air Purifying Apparatus for Tunnels and Tunnel Interior Boards for the Apparatus." Sekisui Jushi Co., Ltd., Japan, and Agency of Industrial Sciences and Technology, assignees. Japan Patent 9271635. 21 October 1997. 128:16052 CA.

138. Ibusuki, Takatsugu, Koji Takeuchi, Nobuaki Negishi, Kazunobu Ota, Takahiro Doi, and Toyomitsu Banno, inventors. "Exhaust Gas Purification Materials." Sekisui Jushi Co., Ltd., Japan, and Agency of Industrial Sciences and Technology, assignees. Japan Patent 10094588. 14 April 1998. 128:298715 CA.

139. Ichiba, Yasuyoshi, inventor. "Titanium Oxide Photocatalyst and Its Manufacture." Usui, Miho, Japan, Masakazu Wakahara, and Yasuyoshi Ichiba, assignees. Japan Patent 10314584. 2 December 1998. 130:58995 CA.

140. Ichikawa, Shinichi and Yoshinori Furukawa, inventors. "Photocatalyst-Equipped Air Conditioner." Hitachi, Ltd., Japan, assignee. Japan Patent 10235153. 8 September 1998. 129:220409 CA.

141. Ichikawa, Shinichi and Yoshinori Furukawa, inventors. "Formation of Photocatalyst Coatings on Tubes for Fluorescent Lamps and Fluorescent Lamp Tubes with the Photocatalyst Coatings." Hitachi, Ltd., Japan, assignee. Japan Patent 10241560. 11 September 1998. 129:284736 CA. 
142. Ichikawa, Shinichi, Yoshinori Furukawa, and Shigeru Azuhata, inventors. "Photocatalyst -Loaded Fluorescent Lamp for Air Purification.” Hitachi, Ltd., Japan, assignee. Japan Patent 10116587. 6 May 1998. 129:31634 CA.

143. Iguchi, Katsumi, Yasuhiko Kochiyama, and Hitoshi Shibuya, inventors. "Dust-Collection Parts Using Photocatalysts for Ionization-Type Air Purifiers.” Daikin Industries, Ltd., Japan, assignee. Japan Patent 10309493. 24 November 1998. 130:70612 CA.

144. Iguchi, Katsumi, Yasuhiko Kochiyama, and Hitoshi Shibuya, inventors. "Electric Dust Collecting Element Provided with Photocatalyst." Daikin Industries, Ltd., Japan, assignee. Japan Patent 10309491. 24 November 1998. 130:6934 CA.

145. Iguchi, Katsumi, Yasuhiko Kochiyama, and Hitoshi Shibya, inventors. "Electric Dust Collecting Element Provided with Photolysis Catalyst." Daikin Industries, Ltd., Japan, assignee. Japan Patent 10309492. 24 November 1998. 130:6935 CA.

146. Iida, Tadakuni, inventor. "Deodorization Apparatus and Showcase Utilizing Photolysis Catalyst." Toshiba Corp., Japan, assignee. Japan Patent 09308818. 2 December 1997. 128:79200 CA.

147. Iimura, Keiji, inventor. "Photocatalyst-Containing Apparatus and Reactor for High Utilization of Light.” Iimura, Keiji, Japan, assignee. Japan Patent 09225295. 2 September 1997. 127:209641 CA.

148. Iimura, Mitsuo, Tadanori Domoto, and Eiji Takahata, inventors. "Polytetrafluoroethylene Fibers with Antibacterial Properties and Their Production Method.” Nitto Denko Corp., Japan, assignee. Japan Patent 09256217. 30 September 1997. 127:294552 CA.

149. Iimura, Mitsuo, Tadanori Doumoto, and Kenji Sato, inventors. "Method for Manufacture of Air Purification Filter Using Titania Photocatalyst on Fluorine-Containing Resin." Nitto Denko Corp., Japan, assignee. Japan Patent 10005545. 13 January 1998. 128:144598 CA.

150. Iimura, Mitsuo, Kenji Sato, and Tadanori Michimoto, inventors. "Manufacture of Non-Woven Fiber Sheet With Fluorocarbon Resin Used in Filter for Decomposition of Low-Molecular Polysiloxane in Clean Room in Semiconductor and Pharmaceutical Industries." Nitto Denko Corp., Japan, assignee. Japan Patent 10202063. 8 August 1998. 129:192980 CA.

151. Iino, Akira, inventor. "Manufacture of Coated Optical Fibers." Furukawa Electric Co., Ltd., Japan, assignee. Japan Patent 10059749. 3 March 1998. 128:208034 CA.

152. Iino, Akira, inventor. "Titanium Oxide and Its Low-Cost Manufacture for Purification of Water and Air.” Furukawa Electric Co., Ltd., Japan, assignee. Japan Patent 10059721. 3 March 1998. 128:196440 CA.

153. Ikeda, Junichi, inventor. "Self-Decomposing Polymer Compositions Containing Titanium Dioxide as Photocatalyst." Kyoeisha Chemical Co., Ltd., Japan, assignee. Japan Patent 10212388. 11 August 1998. 129:190097 CA.

154. Ikehata, Hisashi and Tadanori Michimoto, inventors. "Titanium Dioxide Beads-Containing Photodegradable Adhesive Compositions.” Nitto Denko Corp., Japan, assignee. Japan Patent 10265749. 6 October 1998. 129:303456 CA.

155. Ikenaga, Junko, Takeyuki Yamaki, Koichi Takahama, Toshiharu Sako, and Hirotsugu Kishimoto, inventors. "Functional Coated Articles and Manufacture and Uses Thereof in Building Materials, Doors, Fences, Windows, Automobiles, Machines, Advertising Towers, Illumination Devices, and 
Road Accessories.” Matsushita Electric Works, Ltd., Japan, Junko Ikenaga, Takeyuki Yamaki, Koichi Takahama, Toshiharu Sako, and Hirotsugu Kishimoto, assignees. World Patent 9825711. 18 June 1998. 129:82820 CA.

156. Ikukata, Tsutomu and Kiyoshi Miyashita, inventors. "Hydrophilic Thin Layers and Vehicle Mirrors and Glass Products Having the Layers.” Ichikoh Industries, Ltd, Japan, assignee. Japan Patent 10330131. 15 December 1998. 130:42064 CA.

157. Imai, Shigeo and Junko Takada, inventors. "Ceramic Products Having Photocatalyst Functions and Their Manufacture.” Inax Corp., Japan, assignee. Japan Patent 10337477. 22 December 1998. 130:70196 CA.

158. Inoue, Takahiro and Yasuji Sawada, inventors. "Manufacture of Photocatalyst Materials for Waste Gas Treatment.” Matsushita Electric Works, Ltd., Japan, assignee. Japan Patent 09262466. 7 October 1997. 127:336082 CA.

159. Inui, Tomoyuki, Masashi Inoue, Fumiaki Otani, Seiichi Nishimoto, Yoshinari Kazuyoshi, Hiroshi Konan, and Nobuo Iwane, inventors. "Manufacture of Anatase-Type Titanium Oxide Microparticles Showing Photocatalytic Activity." Teikoku Kako Co., Ltd., Japan, assignee. Japan Patent 09239269. 16 September 1997. 127:313081 CA.

160. Ishida, Tasaku and Hiroyasu Furukawa, inventors. "Deodorization Mesh Sheet with Titania Photocatalyst for Air Purification.” KG Pack K.K., Japan, assignee. Japan Patent 09154925. 17 June 1997. 127:139601 CA.

161. Ishihara, Nobuo, inventor. "Activated-Sludge Wastewater Treatment with Photochemical Process." Mitsubishi Heavy Industries, Ltd., Japan, assignee. Japan Patent 10151498. 9 June 1998. 129:31809 $C A$.

162. Ishihara, Shigehisa and Takashi Kozuka, inventors. "Composites for Environmental Purification by Especially Removing NOx and Their Manufacture." Shin Meiwa Industry Co., Ltd., Japan, assignee. Japan Patent 10028861. 3 February 1998. 128:171517 CA.

163. Ishii, Nobuaki, Koichi Wada, Kazuo Sekiguchi, Michihiro Takama, Shinobu Ito, Kotaro Yano, Yasuo Saito, and Keiji Kawasaki, inventors. "Cosmetic Preparation, Silica-Coated Metal Oxide Powder, and Process for Producing Them." Showa Denko K.K., Japan, assignee. World Patent 9847476. 29 October 1998. 129:335503 CA.

164. Ishikawa, Koji, Izumi Saito, Kenichi Sakuma, and Kenji Murakami, inventors. "Photocatalytic Deodorization Apparatus.” NHK Spring Co. Ltd., Japan, assignee. Japan Patent 08182749 A2. 16 July 1996. 125:255937 $C A$.

165. Ishikawa, Takao, Daigoro Kamoto, Tomoji Ooishi, and Ken Takahashi, inventors. "Oxide Photocatalyst Thin Film and Material Containing It." Hitachi, Ltd., Japan, assignee. Japan Patent 10314600. 2 December 1998. 129:349011 CA.

166. Ishikawa, Takao, Daigoro Kamoto, Tomoji Ooishi, Ken Takahashi, Tadanori Domoto, and Kazushige Shibata, inventors. "Stain Prevention of Photocatalyst Film Using Antistatic Agent and Stain-Resistant Film and Product." Hitachi, Ltd., Japan, and Nitto Denko Corp., assignees. Japan Patent 10314598. 2 December 1998. 129:349010 CA.

167. Ishikawa, Takao, Tomoji Ooishi, Daigorou Kamoto, Ken Takahashi, Takuo Kawaguchi, Tetsuo Ishikawa, Yuka Hirota, and Noriko Shimasaki, inventors. "Thin Photocatalytic Films and Articles 
Using the Same, Such As Air Purifiers, Fans, Vacuum Cleaners, Clothes Dryers, Dishwashers, Garbage Disposers, etc., and Photocatalysts Used Therein.” Ltd. Japan Hitachi, Takao Ishikawa, Tomoji Ooishi, Daigorou Kamoto, Ken Takahashi, Takuo Kawaguchi, Tetsuo Ishikawa, Yuka Hirota, and Noriko Shimasaki, assignees. World Patent 9812048. 26 March 1998. 128:231741 CA.

168. Ishikiriyama, Mamoru, inventor. "Fluid Purification Apparatus Using Photocatalyst." Toyota Motor Corp., Japan, assignee. Japan Patent 10180044. 7 July 1998. 129:99207 CA.

169. Ishikiriyama, Mamoru, inventor. "Apparatus for Purification of Water Utilizing Photocatalyst." Toyota Motor Corp., Japan, assignee. Japan Patent 10202255. 4 August 1998. 129:166016 CA.

170. Ishizawa, Hitoshi, inventor. "Manufacture of Anatase-Type Titanium Oxide Film by Anodization of Titanium.” Nikon Corp., Japan, assignee. Japan Patent 09157891. 17 June 1997. 127:57170 CA.

171. Ito, Katsuji and Nobuyuki Miyazaki, inventors. "Fluoropolymer-Based Water-Repellent Coating Compositions.” Asahi Glass Co., Ltd., Japan, assignee. Japan Patent, 10130539. 19 May 1998. 129:55506 CA.

172. Iwai, Shigeki and Masatoshi Morita, inventors. "Nitrogen Oxide-Decomposing Synthetic Fibers." Nippon Ester Co., Ltd., Japan, assignee. Japan Patent 09228139. 2 September 1997. 127:221922 $C A$.

173. Iwasa, Tadanobu, inventor. "Titania Photocatalyst Used on Vehicle Curtain for Air Purification." Toyoda Gosei Co., Ltd., Japan, assignee. Japan Patent, 09095133. 8 April 1997. 127:39018 CA.

174. Janata, Jiri, Gary L. McVay, Charles H. Peden, and Gregory J. Exarhos, inventors. "Apparatus for Photocatalytic Destruction of Internal Combustion Engine Emissions during Cold Start." Battelle Memorial Institute, USA, assignee. United States Patent 5778664. 14 July 1998. 129:126423 CA.

175. Kaburaki, Nobuko and Toshinori Sakagami, inventors. "Coating Compositions with Excellent Storability and Good Balance of Weather and Heat Resistance and Transparency." Japan Synthetic Rubber Co., Ltd., Japan, assignee. Japan Patent 10183061. 7 July 1998. 129:150140 CA.

176. Kadoi, Hideo, inventor. "Photocatalysts and Environmental Pollutant-Removing Materials Using Them.” Ishikawajima Harima Heavy Ind., Japan, assignee. Japan Patent JP. 08215563 A2. 27 August 1996. 125:255904 CA.

177. Kakitani, Tsutomu, Ichiro Yokoseki, Kozo Uemura, Akihiro Inoue, Kazuhiko Yoshikawa, Keisuke Kuga, and Akihiko Yonezawa, inventors. "Apparatus for Treatment of Liquid and/or Water Using Light-Emitting Tube with Photocatalyst.” Toshiba Lighting and Technology Corp., Japan, assignee. Japan Patent 10015544. 20 January 1998. 128:158673 CA.

178. Kakutani, Tomoji, inventor. "Photocatalyst Devices for Treatment and Recovery of Oil Spill on Seawater." Japan, assignee. Japan Patent 10310779. 24 November 1998. 130:7224 CA.

179. Kakutani, Tomoji, inventor. "Purification Apparatus Comprising Photolysis Catalyst for Exhaust Gases and Bath Water.” Kakutani, Tomoji, Japan, assignee. Japan Patent 10309440. 24 November 1998. 130:6904 CA.

180. Kameoka, Kazuhiro, inventor. "Drying Apparatus for Dishes and Control of the Apparatus." Mitsubishi Electric Corp., Japan, and Ltd. Mitsubishi Electric Home Appliance Co., assignees. Japan Patent 09192078. 29 July 1997. 127:137486 CA. 
181. Kamigasa, Satoshi and Isao Akeda, inventors. "Titania-Based Fixed Photocatalysts and Their Manufacture.” Showa Kagaku Kogyo Kk, Japan, and Ishihara Sangyo Kaisha, assignees. Japan Patent 08266897 A2. 15 October 1996. 126:36386 CA.

182. Kamitani, Kiyoshi, Yoshihiko Murata, and Hiroshi Yamada, inventors. "Cement-Based Hydraulic Compositions Having NOx Removal Function.” Mitsubishi Materials Corp., Japan, assignee. Japan Patent 10291849. 4 November 1998. 129:334600 CA.

183. Kamitani, Kyoshi, Yoshihiko Murata, and Hiroshi Yamada, inventors. "Manufacture of Materials for Removal of Toxic Substances from Air." Mitsubishi Materials Corp., Japan, assignee. Japan Patent 10328611. 15 December 1998. 130:42613 CA.

184. Kamiusuki, Toshiro, inventor. "Cleaning Compositions Containing Chelating Agents and Photocatalysts of Semiconductors.” Neos Co., Ltd., Japan, assignee. Japan Patent 09235596. 9 September 1997. 127:249761 CA.

185. Kamiusuki, Toshiro and Yasuyuki Morikawa, inventors. "Nontoxic Rust Removing Composi- tion." Neos Co. Ltd., Japan, assignee. Japan Patent 09202982. 5 August 1997. 127:179228 CA.

186. Kamoshita, Shinichi, Katsuhisa Osaki, Shigetoshi Suzuki, and Setsuko Oura, inventors. "Photocatalyst-Coated Metal Sheets and Their Manufacture." Nisshin Steel Co., Ltd., Japan, assignee. Japan Patent 09310185. 2 December 1997. 128:104862 CA.

187. Kaneda, Yuji, Masaru Kaneko, Makoto Matsuhisa, Koichi Soeta, Koichi Yamaguchi, Takashi Ibusuku, and Koshi Takeuchi, inventors. "Hydraulic Compositions Containing Photocatalysts and Their Manufacture." Agency of Industrial Sciences and Technology, Japan, Ltd. Onoda Cement Co., and Ltd. Ishihara Sangyo Kaisha, assignees. Japan Patent 10180095. 7 July 1998. 129:84959 CA.

188. Kaneko, Masaru, Makoto Matsuji, Yoshihasa Kaneda, Koichi Soeta, Koichi Yamaguchi, Takashi Ibisuku, and Koshi Takeuchi, inventors. "Manufacture of Compositions Containing Photocatalysts and Method for Application of the Compositions." Agency of Industrial Sciences and Technology, Japan, Ltd. Onoda Cement Co., and Ltd. Ishihara Sangyo Kaisha, assignees. Japan Patent 10180116. 7 July 1998. 129:84969 CA.

189. Kaneko, Toshihiko and Koshi Yamauchi, inventors. "Air Purification Device with Photocatalyst for Domestic and Automobile Uses.” S.T. Chemical Co. Ltd., Japan, assignee. Japan Patent 10192654. 28 July 1998. 129:165540 CA.

190. Kanno, Mitsunobu and Makoto Hayakawa, inventors. "Transfer Sheets Comprising Pressure- or Heat-Sensitive Adhesive Layers and Photocatalyst-Containing Layers and Transfering Methods of Photocatalytic Hydrophilic Thin Films.” Toto Ltd., Japan, assignee. Japan Patent 10180948. 7 July 1998. 129:137365 CA.

191. Kasai, Tadaki, Shigeru Kitano, Hiroshi Nishino, and Kichio Otani, inventors. "Method and Apparatus for Photocatalytically Removing Aromatic Organic Chlorine Compounds from Waste Gases.” Meiwa Industrial Co., Ltd., Japan, assignee. Japan Patent 10328533. 15 December 1998. 130:42597 CA.

192. Kasuga, Tomoko and Masayoshi Hiramatsu, inventors. "Manufacture of Titania-Silica Photocatalyst.” Chubu Electric Power, Japan, assignee. Japan Patent 08257399 A2. 8 October 1996. 
126:39610 CA.

193. Kasuga, Tomoko and Masayoshi Hiramatsu, inventors. "Manufacture of Titania-Based Photocatalyst.” Chubu Electric Power Co., Inc., Japan, assignee. Japan Patent 10015387. 20 January 1998. 128:108345 CA.

194. Kasuga, Tomoko and Masayoshi Hiramatsu, inventors. "Crystalline Titania Nanotube Production Method." Chubu Electric Power Co., Inc., Japan, assignee. Europe Patent 832847. 1 April 1998. 128:232415 CA.

195. Kasukawa, Nobuyuki, inventor. "Air Conditioner Having Titania Photocatalyst for Decompo- sition of Contaminants.” Sanyo Electric Co., Ltd., Japan, assignee. Japan Patent 09133409. 20 June 1997. 127:85248 CA.

196. Kasukawa, Nobuyuki, inventor. "Air Conditioner Having Titania Photocatalyst for Decompo- sition of Contaminants.” Sanyo Electric Co., Ltd., Japan, assignee. Japan Patent 09133408. 20 June 1997. 127:85247 CA.

197. Katabuchi, Osamu, Ritsuko Miyagawa, and Toshio Tadoi, inventors. "Heat-Resistant Antibac- terial Odor-Absorbing Agents for Finishing Fabrics and Treating Fabrics Using Them by Sim- plified Process.” Lion Corp., Japan, assignee. Japan Patent 09296364. 18 November 1997. 128:35952 CA.

198. Katabuchi, Osamu, Minoru Tamura, and Kazuo Kakui, inventors. "Aerosol Compositions for Antifouling and Deodorization Treatment.” Lion Corp., Japan, assignee. Japan Patent 09316435. 9 December 1997. 128:90677 CA.

199. Kataoka, Katsushi, inventor. "Water Treatment with Photocatalysts." Ebara Corp., Japan, assignee. Japan Patent 10202254. 4 August 1998. 129:140167 CA.

200. Kataoka, Katsuyuki, inventor. "Water Purification Using Powdered Photocatalysts." Ebara Corp., Japan, assignee. Japan Patent 09174067. 8 July 1997. 127:99491 CA.

201. Kataoka, Katsuyuki, Mari Fujisaki, and Chiaki Igarashi, inventors. "Treatment of Night Soil Wastewater with Photocatalysts.” Ebara Mfg., Japan, assignee. Japan Patent 09010799. 14 January 1997. 126:176272 CA.

202. Kataoka, Katsuyuki, Chiaki Igarashi, and Mari Fujisaki, inventors. "Treatment of Night Oil Wastewater with Photocatalysts.” Ebara Mfg., Japan, assignee. Japan Patent 09010797. 14 January 1997. 126:176271 CA.

203. Kataoka, Kikuichi, inventor. "Device for Treatment of Waste Gas.” Japan, assignee. Japan Patent 10323525. 8 December 1998. 130:28728 CA.

204. Kato, Kazumi and Hiroshi Togeda, inventors. "Manufacture of Ceramic Porous Thin Films and Photocatalysts.” Kogyo Gijutsuin, Japan, assignee. Japan Patent 08245278 A2. 241996. 125:337020 CA.

205. Kato, Kazumi, Haruyoshi Yamase, and Kenzo Okui, inventors. "Seawater Intake with UV Treatment for Biofouling Prevention." Agency of Industrial Sciences and Technology, Japan, and Bridgestone Corp., assignees. Japan Patent 09105120. 22 April 1997. 127:39437 CA. 
206. Kato, Kenji and Hidenao Hirasawa, inventors. "Method for Supporting Photocatalyst Particles by Using Binder.” Matsushita Seiko Co., Ltd., Japan, assignee. Japan Patent 09271676. 21 October 1997. 127:322432 CA.

207. Kato, Kunichi, inventor. "Manufacture of Photocatalyst Laminated Material for Environment Purification and Solar Cells.” Kato Kikai Seisakusho Kk, Japan, assignee. Japan Patent 09000943. 7 January 1997. 126:190683 CA.

208. Kato, Toshiyuki, Kazuya Okada, Masatoshi Horimoto, and Shunichi Nunokawa, inventors. "Air Purification Apparatus Using Photocatalyst." Daikin Industries, Ltd., Japan, assignee. Japan Patent 10038330. 13 February 1998. 128:221050 CA.

209. Kato, Toshiyuki, Ichiya Okata, Hachiro Kurokawa, and Yasuo Sato, inventors. "Apparatus with Photocatalyst for Deodorization of Indoor Air.” Daikin Industries, Ltd., Japan, assignee. Japan Patent 09322934. 16 December 1997. 128:105723 CA.

210. Kawa, Manabu and Masahiro Nukui, inventors. "Thermoplastic Resin Compositions and Coating Materials therefrom and Structures Having Surfaces Therefrom." Mitsubishi Chemical Industries Ltd., Japan, assignee. Japan Patent 10168325. 23 June 1998. 129:123853 CA.

211. Kawabata, Takashi, Yoshinobu Asano, and Hiroshi Kumai, inventors. "Surface Treatment for Lubrication of Medical Equipments." Nippon Zeon Co., Ltd., Japan, assignee. Japan Patent 10277144. 20 October 1998. 129:335808 CA.

212. Kawakuchi, Takuo, Takao Ishikawa, Tomoji Oishi, Noriko Shimazaki, Yuka Hirota, and Tetsuo Ishikawa, inventors. "Products Containing Low-Temperature Hardenable Oxide Photocatalyst Thin Films Having High Activity." Hitachi, Ltd., Japan, assignee. Japan Patent 10314597. 2 December 1998. 130:42607 CA.

213. Kawamoto, Takeshi, inventor. "Photocatalytic Cell and Its Manufacture." Yazaki Corp., Japan, assignee. Japan Patent 10230168. 2 September 1998. 129:223187 CA.

214. Kawamura, Kyoko, Hiroki Hirata, and Akira Nishihara, inventors. "Photocatalytic Coatings, Their Manufacture, and Films Thereof." Mitsubishi Materials Corp., Japan, assignee. Japan Patent 10259324. 19 September 1998. 129:291259 CA.

215. Kawamura, Kyoko, Hiroki Hirata, and Akira Nishihara, inventors. "Photocatalytic Coatings, Their Manufacture, and Films Thereof." Mitsubishi Materials Corp., Japan, assignee. Japan Patent 10259320. 29 September 1998. 129:291258 CA.

216. Kawashima, Koichi, Ryuji Masuda, and Kazuhiro Kitamura, inventors. "Curtains for Removal of Odors from Indoor Air.” Nippon Muki Kk, Japan, assignee. Japan Patent 08266864 A2. 15 October 1996. 126:36380 CA.

217. Kawashima, Koichi, Ryuji Masuda, and Kazuhiro Kitamura, inventors. "Plate Glass for Air Deodorization.” Nippon Muki Kk, Japan, assignee. Japan Patent 08277147 A2. 22 October 1996. 126:36391 CA.

218. Kawashima, Koichi, Ryuji Masuda, and Kazuhiro Kitamura, inventors. "Inorganic Fiber-Derived Interior Lining Materials with Light-Activated Deodoring Property." Nippon Muki Kk, Japan, assignee. Japan Patent 08311799. 26 November 1996. 126:119027 CA. 
219. Kawashima, Koichi, Sei Myashita, and Juji Katagiri, inventors. "Filter Materials Bearing Photocatalysts, Filter Units Using the Materials, and Filtration Using the Filter Units for Air Purification.” Nippon Muki Kk, Japan, assignee. Japan Patent 08309122. 26 November 1996. 126:108138 CA.

220. Kikuchi, Eiji, inventor. "Removal of Selenate Ions from Wastewaters by Photocatalytic Reduction." Agency of Industrial Sciences and Technology, Japan, assignee. Japan Patent 09239377. 16 September 1997. 127:282941 CA.

221. Kimita, Michio, Hisashi Yamada, Hiroaki Suzuki, and Keijiro Shigeru, inventors. "Bactericidal Compositions for Permeating Concrete Surfaces.” Sumitomo Cement Co., Ltd., Japan, assignee. Japan Patent 09263466. 7 October 1997. 127:335682 CA.

222. Kimura, Kunio, Yasuhiro Fujii, Susumu Kobayashi, and Atsushi Nishino, inventors. "PhotocatalystCoated Construction Material, Especially Wallpaper, and Its Manufacture." Matsushita Electric Industrial Co., Ltd., Japan, assignee. Japan Patent 09300515. 25 November 1997. 128:6802 CA.

223. Kimura, Mikio, inventor. "Air Purification Apparatus Capable of Deodorization and Sterilization of Air and Dust-Collecting Electrodes Therefor.” Toyo Element Industry Co., Japan, assignee. Japan Patent 10328575. 15 December 1998. 130:56393 CA.

224. Kimura, Nobuo, Shiji Abe, Tetsuo Yoshimoto, Ariyoshi Ishizaki, Koji Ueno, Akira Fujishima, and Kazuhito Hashimoto, inventors. "Lighting Devices Having a Photocatalytic Germicidal and Deodorant Reflector or Glove.” Nippon Soda Co., Ltd., Japan, Toshiba Lighting and Technology Corp., Akira Fujishima, and Kazuhito Hashimoto, assignees. Japan Patent 09171707. 30 June 1997. 127:170276 CA.

225. Kimura, Nobuo and Shinji Abe, inventors. "Photocatalyst-Coated Tent Canvases with Improved Resistance to Soiling, Bacteria and Fungi and Structures Using the Canvases." Nippon Soda Co., Ltd., Japan, assignee. Japan Patent 10237769. 8 September 1998. 129:261696 CA.

226. Kimura, Nobuo, Shinji Abe, Tetsuo Yoshimoto, and Shigemichi Fukayama, inventors. "Photocatalyst-Carrying Structure and Photocatalyst Coating Material." Nippon Soda Co., Ltd., Japan, Nobuo Kimura, Shinji Abe, Tetsuo Yoshimoto, and Shigemichi Fukayama, assignees. International Patent 9700134. 3 January 1997. 126:164158 CA.

227. Kimura, Nobuo and Tetsuo Yoshimoto, inventors. "Photocatalysts Loaded Inorganic Fiber Support Sheets for Water Purification and Wastewater Treatment and Deodorization." Nippon Soda Co, Japan, assignee. Japan Patent 08281121. 29 October 1996. 126:79710 CA.

228. Kimura, Nobuo and Tetsuo Yoshimoto, inventors. "Photocatalytic Coating Composition and Photocatalyst-Bearing Structure Usable Particularly under a High-Temp. and High-Humidity Environment and an Outdoor Environment Where Alkali Resistance." Nippon Soda Co., Ltd., Japan, Nobuo Kimura, and Tetsuo Yoshimoto, assignees. World Patent 9815600. 16 April 1998. 128:245314CA.

229. Kimura, Tomoaki and Kazuhiko Tanaka, inventors. "Odor-Absorbing Melt-Blown Nonwoven Fabrics and Manufacture Thereof.” Kuraray Co., Ltd., Japan, assignee. Japan Patent 10131020. 19 May 1998. 129:42312 CA.

230. Kinoshita, Hideo, inventor. "Polymer Material Laminated with Inorganic Photocatalyst Thin-Film 
Layer.” Asahi Chemical Industry Co., Ltd., Japan, assignee. Japan Patent 10329261. 15 December 1998. 130:45199 CA.

231. Kinoshita, Yoshiko, inventor. "Heat-Shrinkable Stretched Films Having Photocatalytic Actions for Microorganism Control and Deodorization, and Articles Covered with the Films." Daisho K.K., Japan, assignee. Japan Patent 10330507. 15 December 1998. 130:53515 CA.

232. Kishimoto, Koji, Koichi Takahama, and Shoji Nakagawa, inventors. "Manufacture of Titanium Oxide Membrane Having Photocatalyst Activity.” Matsushita Electric Works, Ltd., Japan, assignee. Japan Patent 10101335. 21 April 1998. 128:272356 CA.

233. Kitagawa, Shiro, inventor. "Water Purifying Apparatus." Kitagawa Industries Co., Ltd., Japan, assignee. Japan Patent 10277544. 20 October 1998. 129:347082 CA.

234. Kitajima, Kunio and Toichiro Isawa, inventors. "Ceramics Containing Mica-Supported Photocatalyst and Their Manufacture.” Japan, assignee. Japan Patent 10323569. 8 December 1998. 130:31094 $C A$.

235. Kitajima, Kunio and Toichiro Isawa, inventors. "Photocatalysts Bonded to Intercalated Mica and Their Manufacture.” Japan, assignee. Japan Patent 10323567. 8 December 1998. 130:31093 CA.

236. Kitamura, Atsushi and Makoto Hayakawa, inventors. "Railroad Vehicles with Prevention of Accident Caused by Ice/Snow Aggregates.” Toto Ltd., Japan, assignee. Japan Patent 10287240. 27 1998. 130:4946 CA.

237. Kitamura, Atsushi and Makoto Hayakawa, inventors. "Photocatalytic Hydrophilic Material for Windshield Glass, Window, and Lense and Its Manufacture.” Toto Ltd., Japan, assignee. Japan Patent 10085608. 7 April 1998. 128:302040 CA.

238. Kitamura, Atsushi and Makoto Hayakawa, inventors. "Photocatalytic Hydrophilic Material for Windshield Glass, Window, and Lense and Its Manufacture.” Toto Ltd., Japan, assignee. Japan Patent 10085610. 7 April 1998. 128:288275 CA.

239. Kitamura, Atsushi and Makoto Hayakawa, inventors. "Photocatalytic Hydrophilic Material for Windshield Glass, Window, and Lense and Its Manufacture.” Toto Ltd., Japan, assignee. Japan Patent 10085609. 7 April 1998. 128:288274 CA.

240. Kitamura, Atsushi and Makoto Hayakawa, inventors. "Formation of Hydrophilic Parts Associated with Photocatalytic Effect and the Parts Having Self-Cleaning Property." Toto Ltd., Japan, assignee. Japan Patent 10095635. 14 April 1998. 128:298459 CA.

241. Kitamura, Atsushi and Makoto Hayakawa, inventors. "Hydrophilic Components with Photocatalytic Activity and Their Manufacture.” Toto Ltd., Japan, assignee. Japan Patent 10147771. 2 June 1998. 129:71034 CA.

242. Kitamura, Atsushi and Makoto Hayakawa, inventors. "Hydrophilic Components with Photocatalytic Activity and Their Manufacture.” Toto Ltd., Japan, assignee. Japan Patent 10147770. 2 June 1998. 129:71033 CA.

243. Kitamura, Atsushi and Makoto Hayakawa, inventors. "Photocatalytic Hydrophilic Materials, Their Manufacture, and Photocatalytic Hydrophilic Coating Compositions.” Toto Ltd., Japan, assignee. 
Japan Patent 10152346. 9 June 1998. 129:57699 CA.

244. Kitamura, Atsushi and Makoto Hayakawa, inventors. "Silicone-Coated Parts with Lasting Water Repellency and Water-Repellent Coating Compositions Therefor." Toto Ltd., Japan, assignee. Japan Patent 10152626. 9 June 1998. 129:96670 CA.

245. Kitamura, Atsushi and Makoto Hayakawa, inventors. "Chromium-Containing Material Having Photocatalytic Surface Layer with High Hydrophilicity." Toto Ltd., Japan, assignee. Japan Patent 10156992. 16 June 1998. 129:47334 CA.

246. Kitamura, Atsushi and Makoto Hayakawa, inventors. "Ice- and Snow-Repellent Roofing Materials Coated with Photocatalyst-Containing Silicones." Toto Ltd., Japan, assignee. Japan Patent 10159264. 16 June 1998. 129:96672 CA.

247. Kitamura, Atsushi and Makoto Hayakawa, inventors. "Ice- and Snow-Repellent Antennas." Toto Ltd., Japan, assignee. Japan Patent 10163719. 19 June 1998. 129:68932 CA.

248. Kitamura, Atsushi and Makoto Hayakawa, inventors. "Heat-Insulating Showcases for Food." Toto Ltd., Japan, assignee. Japan Patent 10192103. 28 July 1998. 129:110216 CA.

249. Kitamura, Atsushi and Makoto Hayakawa, inventors. "Hydrophobic Sound Insulation Walls." Toto Ltd., Japan, assignee. Japan Patent 10195829. 28 July 1998. 129:179125 CA.

250. Kitamura, Atsushi and Makoto Hayakawa, inventors. "Mirrors Having Hydrophobic Surfaces for Bathroom Use.” Toto Ltd., Japan, assignee. Japan Patent 10192110. 28 July 1998. 129:178949 CA.

251. Kitamura, Atsushi and Makoto Hayakawa, inventors. "Soil-Resistant Wheels." Toto Ltd., Japan, assignee. Japan Patent 10193901. 28 July 1998. 129:123889 CA.

252. Kitamura, Atsushi and Makoto Hayakawa, inventors. "Soilproofing Coatings for Automobile Body." Toto Ltd., Japan, assignee. Japan Patent 10195385. 28 July 1998. 129:176992 CA.

253. Kitamura, Atsushi and Makoto Hayakawa, inventors. "Stain-Free Blinds." Toto Ltd., Japan, assignee. Japan Patent 10196249. 28 July 1998. 129:126212 CA.

254. Kitamura, Atsushi and Makoto Hayakawa, inventors. "Water-Repellent Decorative Sheets for Road Applications." Toto Ltd., Japan, assignee. Japan Patent 10193524. 28 July 1998. 129:149896 CA.

255. Kitamura, Atsushi and Makoto Hayakawa, inventors. "Heat Exchanger Fins with Long-Lasting Water Repellency.” Toto Ltd., Japan, assignee. Japan Patent 10197192. 31 July 1998. 129:123892 $C A$.

256. Kitamura, Atsushi and Makoto Hayakawa, inventors. "Hydrophilic Coating Compositions." Toto Ltd., Japan, assignee. Japan Patent 10237357. August 1998. 129:232073 CA.

257. Kitamura, Atsushi and Makoto Hayakawa, inventors. "Antisoiling Bathtubs with Water-Repellent Coatings on the Surface of Apron.” Toto Ltd., Japan, assignee. Japan Patent 10201655. 4 August 1998. 129:190538 CA.

258. Kitamura, Atsushi and Makoto Hayakawa, inventors. "Motorcycle Instrument Panel Covers Having Water Drop Adhesion Prevention Properties.” Toto Ltd., Japan, assignee. Japan Patent 10206576. 7 August 1998. 129:137369 CA. 
259. Kitamura, Atsushi and Makoto Hayakawa, inventors. "Water-Repellent Mirrors for Roadsides." Toto Ltd., Japan, assignee. Japan Patent 10206616. 7 August 1998. 129:142415 CA.

260. Kitamura, Atsushi and Makoto Hayakawa, inventors. "Antisoiling Water-Repellent Coatings for External Building Materials.” Toto Ltd., Japan, assignee. Japan Patent 10212809. 11 August 1998. 129:190547 CA.

261. Kitamura, Atsushi and Makoto Hayakawa, inventors. "Covers for Solar Cells." Toto Ltd., Japan, assignee. Japan Patent 10214985. 11 August 1998. 129:163915 CA.

262. Kitamura, Atsushi and Makoto Hayakawa, inventors. "Porcelain Insulators and Water-Repellent Coatings Therefor." Toto Ltd., Japan, assignee. Japan Patent 10214530. 11 August 1998. 129:204236 CA.

263. Kitamura, Atsushi and Makoto Hayakawa, inventors. "Transparent Stain-Resistant Structural Materials with Long-Lasting Water Repellency.” Toto Ltd., Japan, assignee. Japan Patent 10211680. 11 August 1998. 129:149911 CA.

264. Kitamura, Atsushi and Makoto Hayakawa, inventors. "Water-Repellent Glass for Windows of Buildings.” Toto Ltd., Japan, assignee. Japan Patent 10212139. 11 August 1998. 129:152390 CA.

265. Kitamura, Atsushi and Makoto Hayakawa, inventors. "Antisoiling Silicone-Laminated Panels." Toto Ltd., Japan, assignee. Japan Patent 10219147. 18 August 1998. 129:218009 CA.

266. Kitamura, Atsushi and Makoto Hayakawa, inventors. "Railway Cars Having Antifouling Coatings with Excellent Retention of Water Repellency." Toto Ltd., Japan, assignee. Japan Patent 10216629. 18 August 1998. 129:150158 CA.

267. Kitamura, Atsushi and Makoto Hayakawa, inventors. "Glass Lens Including Water-Repellent Silicone Coating Containing Photocatalyst Particles." Toto Ltd., Japan, assignee. Japan Patent 10221503. 21 August 1998. 129:167940 CA.

268. Kitamura, Atsushi and Makoto Hayakawa, inventors. "Plastic Lens Having Water-Repellent Silicone Coating Containing Photocatalyst Particles." Toto Ltd., Japan, assignee. Japan Patent 10221504. 21 August 1998. 129:167941 CA.

269. Kitamura, Atsushi and Makoto Hayakawa, inventors. "Aircraft Bodies Coated with Water-Repellent and Antistaining Silicone Layers.” Toto Ltd., Japan, assignee. Japan Patent 10226765. 25 August 1998. 129:204257 CA.

270. Kitamura, Atsushi and Makoto Hayakawa, inventors. "Photocatalytic Hydrophilic Member, Its Production, and Photocatalytic Hydrophilic Coating Composition.” Toto Ltd., Japan, assignee. Japan Patent 10225639. 25 August 1998. 129:165113 CA.

271. Kitamura, Atsushi and Makoto Hayakawa, inventors. "Antisoiling Bathtubs." Toto Ltd., Japan, assignee. Japan Patent 10229950. 2 September 1998. 129:177016 CA.

272. Kitamura, Atsushi and Makoto Hayakawa, inventors. "Illumination Apparatus." Toto Ltd., Japan, assignee. Japan Patent 10269814. 9 October 1998. 129:337468 CA. 
273. Kitamura, Atsushi and Makoto Hayakawa, inventors. "Railroad Vehicles Having Snow-Repellent Surfaces for Prevention of Stone Scattering.” Toto Ltd., Japan, assignee. Japan Patent 10287238. 27 October 1998. 129:317702 CA.

274. Kitamura, Atsushi and Makoto Hayakawa, inventors. "Photocatalyst-Coated Parts Exhibiting Improved Hydrophilicity on Visible Light Irradiation.” Toto Ltd., Japan, assignee. Japan Patent 10310653. 24 November 1998. 130:39857 CA.

275. Kitamura, Atsushi, Makoto Hayakawa, Mitsumasa Kanno, and Mitsuyoshi Machida, inventors. "Water-Repellent Coating Compositions and Their Components." Toto Ltd., Japan, assignee. Japan Patent, 10237380. 8 September 1998. 129:246617 CA.

276. Kitamura, Atsushi, Makoto Hayakawa, and Mitsuyoshi Machida, inventors. "Articles Having Super Water-Repellent Surfaces.” Toto Ltd., Japan, assignee. Japan Patent 10237431. 8 September 1998. 129:246621 CA.

277. Kitamura, Masaki and Juko Fujita, inventors. "Photocatalyst-Loaded Zeolite as Purification Agent for Water in Fish Tank.” Japan Storage Battery Co Ltd, Japan, assignee. Japan Patent JP. 08228636 A2. 10 September 1996. 126:11391 CA.

278. Kitayama, Toshie and Yasuhiro Matsuda, inventors. "Manufacture of Metal Oxides Intercalated with Clay Minerals.” Nikki Chemical Co., Ltd., Japan, assignee. Japan Patent 10338516. 22 December 1998. 130:54455 CA.

279. Kodama, Masahiro and Keiko Ikeda, inventors. "Loading of Inorganic Particles on Activated Carbon.” Ishihara Sangyo Kaisha, Japan, assignee. Japan Patent 09000948. 7 January 1997. 126:173829 CA.

280. Koike, Hironobu, Yasuyuki Oki, and Katsumi Akata, inventors. "Photocatalyst of Titania Fibers." Sumitomo Chemical Co., Ltd., Japan, assignee. Japan Patent 09276705. 28 October 1997. 127:336246 CA.

281. Kojima, Eiichi and Makoto Hayakawa, inventors. "Tires and Brake Pads with Resistance to Hydroplaning and Improved Braking Efficiency." Toto Ltd., Japan, assignee. Japan Patent 09315106. 9 December 1997. 128:89931 CA.

282. Kojima, Eiichi, Mitsuyoshi Machida, Keiichiro Norimoto, Makoto Hayakawa, and Tatsuhiko Kuga, inventors. "Evaluation of Photocatalytic Films." Toto Ltd, Japan, assignee. Japan Patent 08338808. 24 December 1996. 126:164157 CA.

283. Kojima, Hiroyuki, Kyoji Yamazaki, Katsuyuki Itde, Kenichi Nakaoka, Junichi Nakajima, and Kazuo Hayashi, inventors. "Optical Imaging Display with LED." Toshiba Lighting and Tech- nology Corp., Japan, assignee. Japan Patent 10031434. 3 February 1998. 128:198516 CA.

284. Kojo, Takakazu and Makoto Hayakawa, inventors. "Primer Compositions for Binding Photocatalytic Titania on Plastics and Photocatalytic Components Therefrom." Toto Ltd., Japan, assignee. Japan Patent 10195384. 28 July 1998. 129:150146 CA.

285. Kojo, Takakazu and Makoto Hayakawa, inventors. "Primer Compositions for Binding Photocatalytic Titania on Plastics and Photocatalytic Components Therefrom." Toto Ltd., Japan, assignee. Japan Patent 10195380. 28 July 1998. 129:150145 CA. 
286. Kojo, Takakazu and Makoto Hayakawa, inventors. "Primer Compositions for Binding Photocatalytic Titania on Plastics and Photocatalytic Components Therefrom." Toto Ltd., Japan, assignee. Japan Patent 10195336. 28 July 1998. 129:150143 CA.

287. Komatsu, Teruo, Akio Harada, and Ryosuke Ueyama, inventors. "Ultrafine Metal Particle Carrying Photocatalyst, Highly Functional Material Loaded with the Photocatalyst, and Method of Manufacturing Them.” Daiken Chemical Co., Ltd., Japan, Teruo Komatsu, Akio Harada, and Ryosuke Ueyama, assignees. World Patent 9811984. 26 March 1998. 128:250621 CA.

288. Komatsu, Toru and Masatoshi Nakamura, inventors. "Cloud-Resistant Elements with Photocatalytic Coatings.” Murakami Kaimeido K.K., Japan, assignee. Japan Patent 10036144. 10 February 1998. 128:157946 CA.

289. Kondo, Yasuto, inventor. "Kitchen Facilities with Their Surfaces Coated with Photocatalyst for Decomposition of Grease Contamination." Sanyo Electric Co., Ltd., Japan, assignee. Japan Patent 09140479. 3 June 1997. 127:112582 CA.

290. Kosaka, Hiroshi, inventor. "Apparatus for Air Purification Using Stacked Filters." Sharp Corp., Japan, assignee. Japan Patent 10085558. 7 April 1998. 128:285892 CA.

291. Koura, Setsuko, Katsuhisa Oosaki, Shigetoshi Suzuki, and Kenji Sakato, inventors. "Coated Metal Plates Having Good Antifouling Properties and Preparation Method Thereof." Nisshin Steel Co., Ltd., Japan, assignee. Japan Patent 10264299. 6 October 1998. 129:317669 CA.

292. Koura, Setsuko, Katsuhisa Osaki, and Shigetoshi Suzuki, inventors. "Oil-Decomposing Filters for Kitchen Range Hoods and Their Manufacture.” Nisshin Steel Co., Ltd., Japan, assignee. Japan Patent 09308809. 2 December 1997. 128:36547 CA.

293. Krug, Herbert, Peter Mueller, Peter W. Oliveira, and Helmut Schmidt, inventors. "Manufacture of Nanostructured Products and Coatings, and the Products and Coatings Obtained." Institut fuer Neue Materialien Gemeinnuetzige G.m.b.H., Germany, assignee. Germany Patent 19719948. 19 November 1998. 130:6582 CA.

294. Kubo, Toshihiro, Goro Funabashi, and Tetsuya Tatsumi, inventors. "Amperometric Sensors." Kubota, Ltd., Japan, assignee. Japan Patent 09089827. 4 April 1997. 127:27822 CA.

295. Kubo, Toshihiro, Goro Funabashi, and Tetsuya Tatsumi, inventors. "Optical Cell for Turbidimeter.” Kubota, Ltd., Japan, assignee. Japan Patent 09089758. 4 April 1997. 127:25590 CA.

296. Kubota, Kaneyoshi, inventor. "Decrease of Dewatered Activated Sludges Excluded from Biological Sewage- and Wastewater Treatment Facilities Using Titanium Dioxide Photocatalysts." Cressend Corporation K.K., Japan, assignee. Japan Patent 10277598. 20 October 1998. 129:280504 $C A$.

297. Kubota, Susumu, Yuka Ida, Machiko Namegaya, and Toru Yamaguchi, inventors. "Air Purifying Apparatus with Washable Structure.” Toshiba Corp., Japan, and Toshiba Audio Visual Engineering K.K., assignees. Japan Patent 10234835. 8 September 1998. 129:192987 CA.

298. Kuga, Tatsuhiko, Taizo Hamano, and Akemi Sone, inventors. "Vessel Containing Antimicrobial Filter for Preserving Flowers." Toto Ltd., Japan, assignee. Japan Patent 10146509. 2 June 1998. 129:65640 CA. 
299. Kunie, Sumio and Masato Endo, inventors. "Sound-Absorbing Materials for Soundproofing Walls." NGK Insulators, Ltd., Japan, assignee. Japan Patent 10212771. 11 August 1998. 129:192665 CA.

300. Kurihara, Tokumitsu, Koichi Morimitsu, Hideki Busaka, Tatsuo Saito, Toshio Utagawa, Kenji Kato, and Takuya Murayama, inventors. "Manufacture of Photocatalyst with Titania Using Sulfur Trioxide.” Titan Kogyo Kk, Japan, and Matsushita Seiko Kk, assignees. Japan Patent 09000942. 7 January 1997. 126:176048 CA.

301. Kusano, Kiichi, Seishi Morioka, Yasunori Sasaki, and Norimaro Sugimoto, inventors. "Deodorization Agent Having Effective Sterilization Function by Light Radiation." Rista K.K., Japan, Riken Adsol Kogyo K.K., and Nippon Eco Material K.K., assignees. Japan Patent 09299462. 25 November 1997. 128:79199 CA.

302. Langford, Cooper H., Giuseppe P. Lepore, and Lalchan Persaud, inventors. "Photocatalyst Compound and Process for Production Thereof." Can. University Technologies International Inc., Cooper H. Langford, Giuseppe P. Lepore, and Lalchan Persaud, assignees. International Patent 9637300. 28 November 1996. 126:96790 CA.

303. Langford, Cooper $\mathrm{H}$. and Yiming Xu, inventors. "Photocatalyst and Its Manufacture." University Technologies International Inc., Can., assignee. World Patent 9626903 A1. 6 September 1996. 125:261110 CA.

304. Lasky, William M. and James H. Cornwell, inventors. "Method and Apparatus for Accelerated Decomposition of Petroleum and Petrochemical-Based Compounds within Filter Media." Dana Corporation, USA, assignee. United States Patent 5817504. 6 October 1998. 129:235162 CA.

305. Machida, Mitsuyoshi and Makoto Hayakawa, inventors. "Antisoiling Exterior Wall Building Materials.” Toto Ltd., Japan, assignee. Japan Patent 10102722. 21 April 1998. 128:283664 CA.

306. Machida, Mitsuyoshi and Makoto Hayakawa, inventors. "Dirt-Resistant Reflective Plates for Road Recognition.” Toto Ltd., Japan, assignee. Japan Patent 10102437. 21 April 1998. 129:7751 CA.

307. Machida, Mitsuyoshi and Makoto Hayakawa, inventors. "Trains Having Stain-Resistant Outside Surface Coatings Containing Photocatalytic Oxide Particles.” Toto Ltd., Japan, assignee. Japan Patent 10100901. 21 April 1998. 128:295916 CA.

308. Machida, Mitsuyoshi and Makoto Hayakawa, inventors. "Solar Cells with Antifouling Covers." Toto Ltd., Japan, assignee. Japan Patent 10107303. 24 April 1998. 128:259546 CA.

309. Machida, Mitsuyoshi and Makoto Hayakawa, inventors. "Antifouling and Water-Repellent Automotive Mirrors.” Toto Ltd., Japan, assignee. Japan Patent 10129428. 19 May 1998. 129:29195 $C A$.

310. Machida, Mitsuyoshi and Makoto Hayakawa, inventors. "Antifouling Blinds." Toto Ltd., Japan, assignee. Japan Patent 10131647. 19 May 1998. 129:19278 CA.

311. Machida, Mitsuyoshi and Makoto Hayakawa, inventors. "Automobile Window Glass with Resistance to Soils and Water Drops.” Toto Ltd., Japan, assignee. Japan Patent 10130037. 19 May 1998. 128:325460 CA.

312. Machida, Mitsuyoshi and Makoto Hayakawa, inventors. "Fluoropolymer-Silicone Blend Based Antisoiling Transparent Coatings.” Toto Ltd., Japan, assignee. Japan Patent 10128229. 980519. 
Heisei. 19 May 1998. 129:42395 CA.

313. Machida, Mitsuyoshi and Makoto Hayakawa, inventors. "Soilproofing and Antidripping Ceramic Insulator.” Toto Ltd., Japan, assignee. Japan Patent 10134660. 22 May 1998. 129:22243 CA.

314. Machida, Mitsuyoshi and Makoto Hayakawa, inventors. "Automobiles with Coatings Resistant to Coal Dust and Exhaust Gases.” Toto Ltd., Japan, assignee. Japan Patent 10147730. 2 June 1998. 129:68931 CA.

315. Machida, Mitsuyoshi and Makoto Hayakawa, inventors. "Roofing Materials Having Ice- and SnowRepellent Coatings.” Toto Ltd., Japan, assignee. Japan Patent 10159265. 16 June 1998. 129:110212 $C A$.

316. Machida, Mitsuyoshi and Makoto Hayakawa, inventors. "Waterdrop-Repelling Electricity Transmission Lines.” Toto Ltd., Japan, assignee. Japan Patent 10162655. 19 June 1998. 129:109901 $C A$.

317. Machida, Mitsuyoshi and Makoto Hayakawa, inventors. "Helmet Shields with Good Water Repellency and Visibility.” Toto Ltd., Japan, assignee. Japan Patent 10168637. 23 June 1998. 129:123859 CA.

318. Machida, Mitsuyoshi and Makoto Hayakawa, inventors. "Motorcycle Instrument Panel Covers Having Water Drop Adhesion Prevention Properties.” Toto Ltd., Japan, assignee. Japan Patent 10168344. 23 June 1998. 129:82842 CA.

319. Machida, Mitsuyoshi and Makoto Hayakawa, inventors. "Glass Lense Having Water-Repellent Coating.” Toto Ltd., Japan, assignee. Japan Patent 10170701. 26 June 1998. 129:73858 CA.

320. Machida, Mitsuyoshi and Makoto Hayakawa, inventors. "Water-Repellent Coated Plastic Lenses Resistant to Adhesion to Water Drops and Loss of Visual Properties.” Toto Ltd., Japan, assignee. Japan Patent 10170702. 26 June 1998. 129:96424 CA.

321. Machida, Mitsuyoshi and Makoto Hayakawa, inventors. "Window Glass for Building." Toto Ltd., Japan, assignee. Japan Patent 10182189. 7 July 1998. 129:84864 CA.

322. Machida, Mitsuyoshi and Makoto Hayakawa, inventors. "Aircraft Bodies Having Surface Coatings Containing Photocatalytic Particles and Water-Repellent Fluoropolymers.” Toto Ltd., Japan, assignee. Japan Patent 10226766. 25 August 1998. 129:204258 CA.

323. Machida, Mitsuyoshi and Makoto Hayakawa, inventors. "Antisoiling Bathtubs.” Toto Ltd., Japan, assignee. Japan Patent 10229951. 2 September 1998. 129:232090 CA.

324. Machida, Mitsuyoshi and Makoto Hayakawa, inventors. "Antisoiling Bathtubs.” Toto Ltd., Japan, assignee. Japan Patent 10229949. 2 September 1998. 129:177015 CA.

325. Machida, Mitsuyoshi and Noboru Hayakawa, inventors. Antifouling Wheels Coated with Silicone Layers Containing Photocatalyst Particles.” Toto Ltd., Japan, assignee. Japan Patent 10129201. 19 May 1998. 129:42398 CA.

326. Machida, Mitsuyoshi, Atsushi Kitamura, and Makoto Hayakawa, inventors. "Railroad Vehicles Having Snow-Repellent Surfaces for Prevention of Stone Scattering.” Toto Ltd., Japan, assignee. Japan Patent 10287237. 27 October 1998. 129:317701 CA. 
327. Maekawa, Masaaki, Satoshi Takeuchi, and Zenichi Yamada, inventors. "Porous Gel Photocatalysts." Sintokogyo, Ltd., Japan, assignee. Japan Patent 10323568. 8 December 1998. 130:42609 $C A$.

328. Majima, Hiroshi, Tokumitsu Kurihara, and Shigeru Nagaoka, inventors. "Photocatalysts and Their Manufacture and Usage.” Titan Kogyo K.K., Japan, assignee. Japan Patent 10249210. 22 September 1998. 129:234954 CA.

329. Makhmutov, Fanil A., Roman Nikolaevich Myshkin, and Elena Ivanovna Tsaryuva, inventors. "Method for Decomposition of Organic Compounds in Water by Using Photocatalyst under UV Radiation.” Isukura Sangyo K.K., Japan, assignee. Japan Patent 10043775. 17 February 1998. 128:221389 CA.

330. Masaki, Yasuhiro, Masaru Takahashi, Kenji Ikishima, and Akito Sakoda, inventors. "Titanium Oxide-Based Photocatalyst, Process for Preparation Thereof, and Use Thereof." Sumitomo Metal Industries, Ltd., Japan, assignee. World Patent 9858736. 30 December 1998. 130:73772 CA.

331. Masaki, Yasuhiro and Tadashi Yao, inventors. "Preparation of Aromatic Hydroxy Compounds by Photooxidation of Aromatic Compounds Using Titania-Containing Metallosilicates." Sumitomo Metal Industries, Ltd., Japan, assignee. Japan Patent 09208511. 12 August 1997. 127:205346 CA.

332. Masaki, Yasuhiro and Tadashi Yao, inventors. "Photocatalyst Supported on Carbonaceous Hollow Grain, Manufacture and Application Thereof.” Sumitomo Metal Industries, Ltd., Japan, assignee. Japan Patent 10028875. 980203. Heisei. 3 February 1998. 128:197246 CA.

333. Masaki, Yasuhiro and Tadashi Yao, inventors. "Photocatalyst, Its Manufacture, and Method of Decomposing and Removing Hazardous Materials." Sumitomo Metal Industries, Ltd., Japan, assignee. Japan Patent 10305230. 17 November 1998. 130:43806 CA.

334. Masaki, Yasuhiro and Tadashi Yao, inventors. "Sols for Titania Photocatalysts and Manufacture and Usage of Photocatalytic Multifunctional Materials." Sumitomo Metal Industries, Ltd., Japan, assignee. Japan Patent 10337478. 22 December 1998. 130:70614 CA.

335. Mashita, Ryuushi and Koichi Kawashima, inventors. "Process and Apparatus for Air Deodorization.” Nippon Muki K.K., Japan, assignee. Japan Patent 09313580. 9 December 1997. 128:52488 $C A$.

336. Massholder, Karl F., inventor. "Filter with Filtering Material Transparent to UV Radiation for Liquids, Esp. Water, and Gases.” Massholder, Karl F., Germany, assignee. Germany Patent 19716277. 22 October 1998. 129:320909 CA.

337. Masuda, Ryuji and Koichi Kawashima, inventors. "Deodorization Method and Apparatus for Refrigerators.” Nippon Muki K.K., Japan, assignee. Japan Patent 09313581. 9 December 1997. 128:92462 CA.

338. Masuda, Ryuji and Koichi Kawashima, inventors. "Oxide Optical Catalyst Having High Shape Stability and Its Manufacture.” Nippon Muki K.K., Japan, assignee. Japan Patent 10028867. 3 February 1998. 128:186448 CA.

339. Masuda, Ryuji, Kazuhiro Kitamura, and Koichi Kawashima, inventors. "Treatment of Trichloroethylene-Containing Wastewater and Photocatalytic Apparatus.” Nippon Muki Kk, Japan, 
assignee. Japan Patent 08323347. 10 December 1996. 126:161651 CA.

340. Masuda, Ryuji, Kazuhiro Kitamura, and Koichi Kawashima, inventors. "Method and Apparatus for Removing Trichloroethylene from Waste Gases.” Nippon Muki K.K., Japan, assignee. Japan Patent 09085052. 31 March 1997. 127:22901 CA.

341. Masuda, Ryuji, Kazuhiro Kitamura, Koichi Kawashima, and Shuhei Yamashita, inventors. "Method and Apparatus for Treating Waste Gas from Dry Cleaning Devices." Nippon Muki K.K., Japan, assignee. Japan Patent 09085051. 31 March 1997. 127:22900 CA.

342. Masuda, Ryuji, Kazuhiro Kitamura, Shuhei Yamashita, and Koichi Kawashima, inventors. "Dry Cleaning Wastewater Treatment and Photocatalytic Apparatus.” Nippon Muki K.K., Japan, assignee. Japan Patent 08323346. 10 December 1996. 126:161652 CA.

343. Masuda, Ryushi and Koichi Kawashima, inventors. "Method and Apparatus for Decomposing and Removing Organic Compounds of Aging Accelerating Gases and Malodorous Gases." Nippon Muki K.K., Japan, assignee. Japan Patent 10151322. 9 June 1998. 129:31629 CA.

344. Matsubara, Koichi, Makoto Takata, Shinichi Koyama, Masaki Okazaki, Atsushi Miura, Yoko Tokusan, and Takashi Goto, inventors. "Photocatalyst-Containing Sheets and Their Manufacture." Moruza K.K., Japan, and Gifu Prefecture, assignees. Japan Patent 10025696. 27 January 1998. 128:181612 CA.

345. Matsuda, Mitsuhiro and Shunsuke Nakayama, inventors. "Formation of Coating Films Having Photochemical Activities for Deodorization and Antibacterial Properties." Dainippon Toryo Co., Ltd., Japan, assignee. Japan Patent 10000363. 6 January 1998. 128:131737 CA.

346. Matsumoto, Atsumi, inventor. "Concrete Stacking Blocks." Hirata Kogyosho Y.K., Japan, assignee. Japan Patent 10331292. 15 December 1998. 130:16675 CA.

347. Matsushima, Masaya, inventor. "Titanium Oxide Photocatalyst Film and Its Manufacture." Honda Acsess K.K., Japan, assignee. Japan Patent 10278168. 20 October 1998. 129:349138 CA.

348. Matsushima, Shigenari, inventor. "Photocatalyst-Coated Material with Improved Weather Resistance.” Honda Acsess K.K., Japan, assignee. Japan Patent 10277402. 20 October 1998. 130:8840 CA.

349. Matsushita, Toshihiko, Yasuyuki Oku, and Eisuke Yamaya, inventors. "Environment Purifying Materials Using Photocatalyst and Their Compositions." Mitsubishi Paper Mills Ltd, Japan, assignee. Japan Patent 08266902 A2. 15 October 1996. 126:36385 CA.

350. Matsuzaki, Masaya, inventor. "Self Cleaning Solar Cells." Honda Acsess K.K., Japan, assignee. Japan Patent 10270732. 9 October 1998. 129:278427 CA.

351. Matsuzaki, Masaya, inventor. "Photocatalytic Deodorization Apparatus." Honda Acsess K.K., Japan, assignee. Japan Patent 10337442. 22 December 1998. 130:70613 CA.

352. Meinzer, Richard A. and Philip J. Birbara, inventors. "Acidified Slurry for a Photocatalytic Semiconductor Coating on Substrates." USA United Technologies Corporation, assignee. International Patent WO. 9637636. 28 November 1996. 126:82119 CA.

353. Miano, Fausto and Enrico Borgarello, inventors. "Method for the Heterogeneous Catalytic 
Photodegradation of Pollutants.” Eniricerche S.p.a, assignee. United States Patent 5053136. 1 October 1991.

354. Michimoto, Tadanori and Takayuki Hiyori, inventors. "Polymer-Supported Photocatalyst Sheets Having Gas-Impermeable Inorganic Internal Layer.” Nitto Denko Corp., Japan, assignee. Japan Patent 10309773. 24 November 1998. 130:6936 CA.

355. Miki, Osamu, Nobuyuki Kanemori, and Shingo Katayama, inventors. "Apparatus for Water Treatment, Ultraviolet Lamp with Photocatalytic Coating therefor, and Its Manufacture." Nippon Steel Corp., Japan, assignee. Japan Patent 10151453. 9 June 1998. 129:32108 CA.

356. Miki, Satoshi and Nobuyuki Kanemori, inventors. "Water Sterilization Using Photocatalyst under Ultraviolet-Light Radiation.” Nippon Steel Corp., Japan, assignee. Japan Patent 10151452. 9 June 1998. 129:32107 CA.

357. Minoshima, Masahiko, inventor. "Apparatus Having Titania Photocatalyst for Ultraviolet-Ray Oxidation in Manufacture of Ultrapure Water.” NEC Corp., Japan, assignee. Japan Patent 09192659. 29 July 1997. 127:225012 CA.

358. Miyadera, Tatsuo, Kiyohide Yoshida, Hiroichi Yamashita, Naoko Aoyama, and Akira Muramatsu, inventors. "Photocatalyst for Removal of Nitrogen Oxides and Process Using the Same." Agency of Industrial Sciences and Technology, Japan, and Riken Corp., assignees. Japan Patent 10033990. 10 February 1998. 128:209444 CA.

359. Miyamoto, Hisashi, inventor. "Apparatus for Purifying Circulated Water.” Aqura Garden Hitec Co., Ltd., Japan, assignee. Japan Patent 10272462. 13 October 1998. 129:280722 CA.

360. Mizukane, Masahiro and Akihiko Kiba, inventors. "Mechanical Sliding System Having Photocatalytic Material on Slideway for Good Lubrication Property." Toto Ltd., Japan, assignee. Japan Patent 10043602. 17 February 1998. 128:174048 CA.

361. Mori, Kazuhiko, inventor. "Method of Coating Titanium Oxide Film Having High Photocatalytic Activity by Anodic Electrolysis." Nihon Parkerizing Co., Ltd., Japan, assignee. Japan Patent 10018082. 20 January 1998. 128:120951 CA.

362. Mori, Kazuhiko, Mitsuru Nakamura, and Sho Honda, inventors. "Polymer Material or Polymer Coating Material Having Photocatalyst Layer on Surface and Its Manufacture.” Nihon Parkerizing Co., Ltd., Japan, assignee. Japan Patent 09313948. 9 December 1997. 128:108347 CA.

363. Moriguchi, Yasuo and Atsushi Takamatsu, inventors. "Back-Reflecting Mirror Showing SelfAntifouling Function under Ultraviolet Ray.” Central Glass Co., Ltd., Japan, assignee. Japan Patent 10201585. 4 August 1998. 129:142421 CA.

364. Morishige, Chikao, Masayoshi Sato, Shigeji Kobase, and Yoshinori Takekawa, inventors. "Thermoplastic Polymer Films Laminated with Photocatalyst-Containing Layers for Deodorant Effect.” Toyobo Co., Ltd., Japan, assignee. Japan Patent 10296920. 10 November 1998. 130:53459 $C A$.

365. Morishige, Chikao, Yoshinori Takekawa, Masayoshi Sato, Kiyoshi Izeki, and Shigeji Kobase, inventors. "Laminated Thermoplastic Films Containing Titanium Oxide Photocatalyst Layer with Improved Adhesion." Toyobo Co., Ltd., Japan, assignee. Japan Patent 10034803. 10 February 1998. 128:168394 CA. 
366. Moroto, Shuuzo, Masao Ando, and Yoshikazu Yamanouchi, inventors. "Operation of Automobile Cabin Air Purification Apparatus and Blower.” Echos Research K.K., Japan, assignee. Japan Patent 09309330. 2 December 1997. 128:79196 CA.

367. Mouri, Motoya, Hiroyuki Koyou, Tatsuro Takeuchi, and Kenji Hiramatsu, inventors. "Deodor- izing Fibers and Method of Producing the Same.” Takeda Chemical Industries, Ltd., Japan, and Ltd. Kuraray Co., assignees. Europe Patent 728855 A1. 28 August 1996. 125:250268 CA.

368. Munetoshi, Yasushi, Ryoichi Kitamura, and Shuzo Ohara, inventors. "Deodorization Spray Having Titania Photocatalyst for Air Purification." Goyo Shiko K.K., Japan, assignee. Japan Patent 09164188. 24 June 1997. 127:166021 CA.

369. Munetoshi, Yasushi, Makoto Sato, Hiroshi Kawahara, and Shuzo Ohara, inventors. "Liquid Colorants Having Lasting and Rapid-Acting Deodorizing Capabilities for Coatings." Goyo Shiko K.K., Japan, assignee. Japan Patent 09227809. 2 September 1997. 127:279641 CA.

370. Murakami, Hajime, Mitsuru Watanabe, Akira Fujishima, and Kazuhito Hashimoto, inventors. "Photocatalyst Powders, Photocatalysts Using Them, Their Manufacture, and Environmental Purification Process.” Ishihara Sangyo Kaisha, Ltd., Japan, Akira Fujishima, and Kazuhito Hashimoto, assignees. Japan Patent 10005598. 13 January 1998. 128:118910 CA.

371. Murakami, Kenji and Kenichi Sakuma, inventors. "Deodorization Filter Used in Air Purification Machine Using Activated Carbon and Photocatalyst.” NHK Spring Co., Ltd., Japan, assignee. Japan Patent 10235154. 8 September 1998. 129:220410 CA.

372. Murakami, Kenji, Kenichi Sakuma, and Izumi Saito, inventors. "Deodorization Apparatus." NHK Spring Co., Ltd., Japan, assignee. Japan Patent 09084866. 31 March 1997. 127:22934 CA.

373. Myai, Jinkichi, inventor. "Manufacture of Photocatalysts." Denki Kagaku Keiki Kk, Japan, assignee. Japan Patent 08299805. 19 November 1996. 126:106022 CA.

374. Myazaki, Norihiko, inventor. "Photocatalytic Films Protecting Light Sources." Kawai Musical Instr. Mfg. Co., Japan, assignee. Japan Patent 09007542. 10 January 1997. 126:178830 CA.

375. Myazaki, Norihiko and Yutaka Hagiwara, inventors. "Manufacturing Method of Titanium Oxide Photocatalyst of High Optical Transmission for Nitrogen Oxide Removal from Air." Kawai Musical Instr. Mfg. Co., Japan, assignee. Japan Patent 09000920. 7 January 1997. 126:190248 CA.

376. Myazaki, Norihiko and Yutaka Hagiwara, inventors. "Photocatalyst Device with High Light Penetration for Water Decomposition.” Kawai Musical Instr. Mfg. Co., Japan, assignee. Japan Patent 09000921. 7 January 1997. 126:190674 CA.

377. Nakada, Nobuyuki and Toshio Arai, inventors. "Construction Materials Having Bactericidal and Fungicidal Properties.” Wai Kei Kei Kk, Japan, assignee. Japan Patent 08302498. 19 November 1996. 126:121078 CA.

378. Nakagawa, Toru, Yasuhito Takahashi, and Sanemori Soga, inventors. "Water-Repellent Ceramic Coating Films Showing Semipermanent Effects without Periodical Washing Maintenances and Manufacture Thereof." Matsushita Electric Industrial Co., Ltd., Japan, assignee. Japan Patent 10219461. 18 August 1998. 129:192517 CA.

379. Nakamura, Ichiro, Yasuaki Kai, and Satoko Sugawara, inventors. "Substrate Having Titania- 
Containing Antifogging Film Showing Improved Durability and Its Manufacture." Nissan Motor Co., Ltd., Japan, assignee. Japan Patent 09241037. 16 September 1997. 127:282225 CA.

380. Nakamura, Toru, Kajiro Ushio, Sumito Shimizu, Tetsuya Oshino, and Katsuhiko Murakami, inventors. "Optical Device Equipped with Gas Purification System.” Nikon Corp., Japan, assignee. Japan Patent 10314575. 2 December 1998. 130:8979 CA.

381. Nakashima, Yoji and Yoshiaki Tomotake, inventors. "Photocatalyst-Containing Paper." Tokushu Paper Mfg. Co., Ltd., Japan, assignee. Japan Patent 10226983. 25 August 1998. 129:232212 CA.

382. Nakashoya, Takanori, Tadahiko Ikeuchi, Chikako Gogori, and Hisashi Suzuki, inventors. "WaterThinned Coating Compositions Having Long-Lasting Antimicrobial and Volatile CompoundAdsorbing Properties.” S.K. Kaken K.K., Japan, assignee. Japan Patent 10259325. 29 September 1998. 129:246669 CA.

383. Nakayama, Shunsuke, Noriyuki Ishida, Atsuhiro Matsuda, and Satoshi Fujii, inventors. "Formation of Photochemically Active Coating Membrane.” Dainippon Toryo Co., Ltd., Japan, assignee. Japan Patent 10251558. 22 September 1998. 129:303737 CA.

384. Nakayama, Shunsuke, Noriyuki Ishida, and Mitsuhiro Matsuda, inventors. "Anticorrosive Multilayer Coatings for Steel Structure and Their Coating Method.” Dainippon Toryo Co., Ltd., Japan, assignee. Japan Patent 10314596. 2 December 1998. 130:67885 CA.

385. Niki, Hiroyuki and Yoshiyuki Okui, inventors. "Manufacture of Hydrophilic Polymer Compositions.” Nippon Glass Fiber Co., Ltd., Japan, assignee. Japan Patent 10237183. 8 September 1998. 129:246501 CA.

386. Nishi, Shiro, Yukitoshi Takeshita, Shigekuni Sasaki, Shigeyuki Tsurumi, Mikio Takashima, Shinji Tsuru, and Fumio Yamamoto, inventors. "Bonding Agents, Bonded Structures and Separation Method of the Structures.” Nippon Telegraph and Telephone Corp., Japan, assignee. Japan Patent 10168423. 23 June 1998. 129:123519 CA.

387. Nishi, Shiro, Yukitoshi Takeshita, Shigekuni Sasaki, Shigeyuki Tsurumi, Mikio Takashima, Shinji Tsuru, and Fumio Yamamoto, inventors. "Method for Decomposing Organic Solid Wastes Containing Plastics Using Photocatalysts." Nippon Telegraph and Telephone Corp., Japan, assignee. Japan Patent 10168223. 23 June 1998. 129:136665 CA.

388. Nishikata, Satoshi, Tomoaki Nishimura, Isao Amano, Takeo Takahashi, and Setsuo Yamada, inventors. "Photocatalyst Sheets for Removal of Pollutants." Fuji Electric Co Ltd, Japan, assignee. Japan Patent 09057096. 4 March 1997. 126:282066 CA.

389. Nishikawa, Kazuo and Yasuaki Sakane, inventors. "Air Conditioner with Photocatalyst Filter and UV Lamp.” Sharp Corp., Japan, assignee. Japan Patent 10238799. 8 September 1998. 129:234949 $C A$.

390. Nishimura, Tomoaki, Kazuteru Aragai, Masahiro Myamoto, Satoshi Nishikata, and Takeo Takahashi, inventors. "Apparatus for Removing Hazardous Gases from Air by Photocatalyst with Regeneration.” Fuji Electric Co. Ltd., Japan, assignee. Japan Patent 09019624. 21 January 1997. 126:203178 CA.

391. Nishimura, Tomoaki, Satoshi Nishikata, and Isao Amano, inventors. "Regeneration of Photocatalysts for Air Purification.” Fuji Electric Co., Ltd., Japan, assignee. Japan Patent 10305214. 17 
November 1998. 130:6933 CA.

392. Nishimura, Tomoaki, Satoshi Nishikata, Isao Amano, Takeo Takahashi, and Setsuo Yamada, inventors. "Regeneration of Titanium Oxide Photocatalysts for Removing Air Pollutants." Fuji Electric Co., Ltd., Japan, assignee. Japan Patent 09155207. 17 June 1997. 127:38949 CA.

393. Nishiyama, Hirotaka and Katsuji Kozeki, inventors. "Photocatalyst Supports with Large Specific Surface Area for Purification of Air and Water.” Kitagawa Industries Co., Ltd., Japan, assignee. Japan Patent 10057816. 3 March 1998. 128:235710 CA.

394. Niwa, Isamu and Koji Suzuki, inventors. "Antifouling and Deodorizing Composite Covering Layers and Interior Finish Materials Covered with the Same.” Toyo Linoleum Co., Ltd., Japan, assignee. Japan Patent 09249871. 22 September 1997. 127:282430 CA.

395. Noda, Hiroyuki, inventor. "Antimicrobial and Weather-Resistant Coating Compositions." Yamagataken Tekunohorisu Zaida, Japan, and Ltd. Nippon Oil and Fats Co., assignees. Japan Patent 09100437. 15 April 1997. 127:36048 CA.

396. Noda, Hiroyuki, inventor. "Water Purifiers Provided with Photolysis Catalysts." Yamagataken Tekunohorisu Zaida, Japan, Sanwa Kanzume K.K., Ltd. Yamamoto Mfg. Co., Teepi Kogyo K.K., New Tech Sugano K.K., Suzuki Seisakusho K.K., Kikuchi Kogyo K.K., and Yamaken K.K., assignees. Japan Patent 09239358. 16 September 1997. 127:252924 CA.

397. Noda, Hiroyuki, inventor. "Manufacture of Fixed Anatase-Type Titanium Dioxide-Coated Catalysts.” Yamagataken Tekunohorisu Zaida, Japan, assignee. Japan Patent 08299789. 19 November 1997. 126:91516 CA.

398. Noda, Hiroyuki, inventor. "Water Purifying Apparatus and Purifying Method Employing Photolysis Catalyst." Yamagataken Tekunoporisu Zaida, Japan, Miwa Kanzume K.K., Ltd. Yamamoto Mfg. Co., Teepi Kogyo K.K., Suzuki Seisakusho K.K., Kikuchi Kogyo K.K., and Yamaken K.K., assignees. Japan Patent 10244256. 14 September 1998. 129:206963 CA.

399. Nogi, Ichio, Hirohide Aoyagi, and Tatsuyuki Arai, inventors. "Formable Titanium Oxide Sticks for Wastewater Treatment.” Quad Gijutsu Sekkei K.K., Japan, and Daishin Netsuki K.K., assignees. Japan Patent 10174863. 30 June 1998. 129:85409 CA.

400. Noguchi, Satoko, Masato Yoshikawa, Nobuko Kato, and Kazuo Naito, inventors. "Photocatalysts and Their Manufacture." Bridgestone Corp., Japan, assignee. Japan Patent 10071337. 17 March 1998. 128:234538 CA.

401. Noguchi, Tomoko, Eiken Chin, Masahito Yoshikawa, and Toshio Naito, inventors. "Metal Oxide Photocatalysts for Oil Decomposition, Deodorization, and Purification of Air and Water." Bridgestone Corp, Japan, assignee. Japan Patent 08309204. 26 November 1996. 126:94238 CA.

402. Noguchi, Tomoko, Masahito Yoshikawa, and Toshio Naito, inventors. "Photocatalysts for Oil Decomposition, Deodorization, and Purification of Air and Water.” Bridgestone Corp, Japan, assignee. Japan Patent 08309202. 26 November 1996. 126:94237 CA.

403. Noguchi, Tomoko, Masahito Yoshikawa, and Toshio Naito, inventors. "Photocatalysts for Oil Decomposition, Deodorization, and Purification of Air and Water." Bridgestone Corp, Japan, assignee. Japan Patent 08309201. 26 November 1996. 126:94236 CA. 
404. Noguchi, Tomoko, Masato Yoshikawa, Nobuko Kato, and Kazuo Naito, inventors. "Photocatalyst Bodies.” Bridgestone Corp., Japan, assignee. Japan Patent 10066878. 10 March 1998. 128:221205 $C A$.

405. Nomura, Eiji, Hitoshi Ando, Koichi Yamaguchi, and Toshihiro Koyama, inventors. "Titanium Oxide- and Bentonite-Based Agents for Pollutant Removal from Wastewaters and Waste Gases." Ishihara Sangyo Kaisha, Japan, assignee. Japan Patent 09010582. 14 January 1997. 126:176312 $C A$.

406. Nomura, Eiji, Yoichi Ishibai, Hiroshi Yabe, and Tadashi Horii, inventors. "Supports for Photocatalysts for Decomposing Hazardous Materials.” Ishihara Sangyo Kaisha, Japan, assignee. Japan Patent 08215577 A2. 27 August 1996. 125:307797 CA.

407. Nomura, Eiji, Toshihiro Koyama, and Junko Koizumi, inventors. "Photocatalysts, Their Manufacture, and Use in Air Purification." Ishihara Sangyo Kaisha, Ltd., Japan, assignee. Japan Patent 09299809. 25 November 1997. 128:79198 CA.

408. Nomura, Eiji, Koichi Yamaguchi, Toshihiro Koyama, and Junko Koizumi, inventors. "Photocatalyst-Containing Agents for Removal of Toxic Substances and Removal of Toxic Substances Using Them.” Ishihara Sangyo Kaisha, Ltd., Japan, assignee. Japan Patent 09290164. 11 November 1997. 128:6792 CA.

409. Nonami, Toru, Hiroshi Taoda, and Tetsuya Kameyama, inventors. "Antimicrobial Products Containing Titania Particles and Antimicrobial Composites and Biocompatible Materials." Agency of Industrial Sciences and Technology, Japan, assignee. Japan Patent 10130112. 19 May 1998. 129:8644 CA.

410. Nonoyama, Nobori and Tetsuo Goto, inventors. "Sound Insulating Panel Provided with Air Purifying Function for Highways." Fujita Corp., Japan, assignee. Japan Patent 10152909. 9 June 1998. 129:31602 CA.

411. Nonoyama, Noboru and Tetsuo Goto, inventors. "Polluted Air Purifying Method for Express Highways.” Fujita Corp., Japan, assignee. Japan Patent 10151323. 9 June 1998. 129:31601 CA.

412. Nonoyama, Noboru and Tetsuo Goto, inventors. "Sound Insulating Panel Unit Provided with Air Purifying Function of Photolysis Catalyst." Fujita Corp., Japan, assignee. Japan Patent 10152910. 9 June 1998. 129:31603 CA.

413. Norimoto, Keiichiro, Makoto Hayakawa, Eiichi Kojima, Shigemichi Fukayama, Kazunori Saito, and Nobuo Kimura, inventors. "Hydrophilic Structural Body Having Durable Photocatalytic Activity." Toto Ltd., Japan, and Ltd. Nippon Soda Co., assignees. Japan Patent 10057817. 3 March 1998. 128:250622 CA.

414. Noritake, Yoshiyuki, inventor. "Staining-Resistant Wax-Based Coating Materials Containing Metal Oxide Photocatalysts for Automobiles.” Toyota Motor Corp., Japan, assignee. Japan Patent 09220524. 26 August 1997. 127:191986 CA.

415. Noritake, Yoshiyuki and Mamoru Sugiura, inventors. "Method for Modification of Coating Surfaces.” Toyota Motor Corp., Japan, assignee. Japan Patent 09225386. 2 September 1997. 127:235748 CA. 
416. Obara, Yuzo and Yasuo Ishii, inventors. "Method and Materials for Release Control of Agrochemical Fumigants Using Photocatalysts." Norinsuisansho Nogyo Kankyo Gi, Japan, assignee. Japan Patent 09263502. 7 October 1997. 127:315784 CA.

417. Ogami, Katsushi, inventor. "Deodorizing Agents." Mitsubishi Paper Mills, Ltd., Japan, assignee. Japan Patent 09084867. 31 March 1997. 127:20391 CA.

418. Ogami, Katsushi, Shinya Hioki, and Yoichiro Azuma, inventors. "Water-Resistant Antisoiling Reflective Sheets for Lighting Apparatus and Blinds.” Mitsubishi Paper Mills, Ltd., Japan, assignee. Japan Patent 10230559. 2 September 1998. 129:232091 CA.

419. Ogami, Katsushi and Takaki Komatsu, inventors. "Adsorption and Decomposition Light Reflection Sheet Used in Luminous Device and Blind for Air Purification.” Mitsubishi Paper Mills, Ltd., Japan, assignee. Japan Patent 10202058. 4 August 1998. 129:192979 CA.

420. Ogata, Shiro, inventor. "Semiconductor-Based Redox Photocatalyst.” Tao K.K., Japan, assignee. Japan Patent 09220477. 26 August 1997. 127:285867 CA.

421. Ogata, Shiro, inventor. "Apparatus for Fluid Agitation and Flowing to Purify Air and Water by Using Titania Photocatalyst.” Tao Inc., Japan, and Shiro Ogata, assignees. World Patent 9733680. 18 September 1997. 127:282773 CA.

422. Ogata, Shiro, inventor. "Floating Photocatalyst Supports for Purification of Fluids and Purifi- cation Apparatus Utilizing the Bodies.” Tao K.K., Japan, assignee. Japan Patent 09290258. 11 November 1997. 128:39081 CA.

423. Ogata, Shiro, inventor. "Sheet Substrates Carrying Photocatalyst Activity and Their Manufac- ture." Tao Inc., Japan, and Shiro Ogata, assignees. World Patent 9800290. 8 January 1998. 128:103359 $C A$.

424. Ogata, Shiro, inventor. "Photocatalyst Member with Long Life of Catalytic Activity and Construction Material Therewith.” Tao K.K., Japan, assignee. Japan Patent 10296888. 10 November 1998. 130:31091 CA.

425. Ogata, Shiro and Yoshimitsu Matsui, inventors. "Photocatalyst Having Silicon Oxide-Titanium Oxide Block Layer.” Tao K.K., Japan, and Tanaka Tensha K.K., assignees. Japan Patent 10235201. 8 September 1998. 129:195738 CA.

426. Ogawa, Takatoshi, Toshio Saito, Sadatoshi Oono, Kiyomichi Kushibe, Fumio Kamikubo, Tatsuya Yasunaga, Takashi Kato, Yoshimasa Ito, Akira Fujishima, and Kazuhito Hashimoto, inventors. "Manufacture of Metal Material Having Photocatalytic Activation Characteristics." Takenaka Komuten Co., Ltd., Japan, and Ltd. Kobe Steel, assignees. Japan Patent 10121266. 12 May 1998. 129:47460 CA.

427. Ogishi Kazuhisa and Keiji Hakakeyama, inventors. "Manufacture of Glass Tubes and Fluorescent Lamps Coated with Photocatalyst Membranes with High Reliability." Toshiba Lighting and Technology Corp., Japan, assignee. Japan Patent 10072241. 17 March 1998. 128:247475 CA.

428. Oguchi, Takahito and Tsutomu Uda, inventors. "Apparatus Having Magnetic Photocatalyst Used for Water Purification.” Okaya Electric Industry Co., Japan, assignee. Japan Patent 09075746. 25 March 1997. 127:23362 CA. 
429. Ohgami, Katsushi, Shinya Hioki, and Youichiro Azuma, inventors. "Laminated Photocatalyst Sheets.” Mitsubishi Paper Mills, Ltd., Japan, assignee. Japan Patent 10264283. 19981006. 6 October 1998. 129:320181 CA.

430. Ohmori, Masahiro, Tadashi Hamanaka, and Hidenori Nakamura, inventors. "Manufacture of Particles, Aqueous Dispersion and Film of Titanium Oxide.” Showa Denko K.K., Japan, assignee. Japan Patent 826633. 4 March 1998. 128:194383 CA.

431. Oishi, Tomoji, Takao Ishikawa, Daigoro Kamoto, Chikako Yoshioka, and Osamu Takahashi, inventors. "Antimicrobial Photocatalyst Films, Their Manufacture, and Uses." Hitachi, Ltd., Japan, assignee. Japan Patent 10076597. 24 March 1998. 128:218196 CA.

432. Okada, Ikuo, Misao Sekimoto, and Korehito Matsuda, inventors. "UV Photolithographic System." Nippon Telegraph and Telephone Corp., Japan, assignee. Japan Patent 10112429. 28 April 1998. 129:22145 CA.

433. Okada, Ikuo, Misao Sekimoto, Korehito Matsuda, Yasunao Saito, and Takashi Ookubo, inventors. "X-Ray Mask Having Protective Film." Nippon Telegraph and Telephone Corp., Japan, and NTT Technology Transfer, assignees. Japan Patent 10125583. 15 May 1998. 129:21471 CA.

434. Okada, Kiyomi, inventor. "Granular Plant Growth Inhibitors Having Titanium Oxide-Containing Films and Their Manufacture.” Sun Energy K.K., Japan, assignee. Japan Patent 09087121. 31 March 1997. 127:30411 CA.

435. Okada, Kiyomi, inventor. "Sheets Containing Titanium Dioxide for Control of Plant Growth and Their Manufacture.” Sun Energy K.K., Japan, assignee. Japan Patent 10236908. 8 September 1998. 129:185469 CA.

436. Okada, Kyomi, inventor. "Solid Plant Growth Inhibitors Containing Titania Photocatalyst and Zeolites and Their Manufacture." Sanenerugii Kk, Japan, assignee. Japan Patent 08319205. 3 December 1996. 126:140992 CA.

437. Okada, Kyomi, inventor. "Manufacture and Use of Water Treatment Agents for Cooling Towers, Ponds, Water Purifying Tanks, and Industrial Wastewater." Sanenerugii Kk, Japan, assignee. Japan Patent 09038668. 10 February 1997. 126:216401 CA.

438. Okata, Ikuo, Misao Sekimoto, Korehito Matsuda, Yasunao Saito, and Takashi Okubo, inventors. "XRay Window." Nippon Telegraph and Telephone Corp., Japan, and NTT Technology Transfer, assignees. Japan Patent 10142399. 29 May 1998. 129:73252 CA.

439. Okata, Shiro, inventor. "Flexible Photocatalyst for Purification, Deodorization, and Sterilization of Air and Water.” Tao K.K., Japan, assignee. Japan Patent 10202110. 4 August 1998. 129:126456 $C A$.

440. Okazaki, Motohiro, Yasushi Tateishi, and Tadahiro Uemura, inventors. "Treatment of OilContaining Wastewater Emulsions from Metalworking.” Toray Industries, Japan, assignee. Japan Patent 09029243. 4 February 1997. 126:242263 CA.

441. Okazaki, Toshihiro and Mamoru Ishikiriyama, inventors. "Photocatalytic Water Purification Apparatus.” Toyota Motor Corp., Japan, assignee. Japan Patent 10290981. 4 November 1998. 129:306276 CA. 
442. Okeda, Takemi, Tomohide Matsumoto, Tasuku Kawai, and Satoshi Furuta, inventors. "Fluid Treating Apparatus for Air and Water.” Matsushita Electric Industrial Co., Ltd., Japan, assignee. Japan Patent 09253637. 30 September 1997. 127:336402 CA.

443. Okuda, Nobuyasu, Takehiko Osawa, Toshio Saito, Takatoshi Ogawa, and Takeshi Hiromatsu, inventors. "Apparatus for Treatment of Gases Containing Volatile Organic Compounds by UV Light Irradiation in the Presence of Photocatalyst." Takenaka Komuten Co., Ltd., Japan, assignee. Japan Patent 09103644. 22 April 1997. 127:39007 CA.

444. Okuda, Nobuyasu, Takehiko Osawa, Toshio Saito, Takatoshi Ogawa, and Takeshi Hiromatsu, inventors. "Cascading Channel for Photocatalytic Treatment of Landscaping Pond Water." Takenaka Komuten Co., Ltd., Japan, assignee. Japan Patent 09131587. 20 May 1997. 127:85763 CA .

445. Okuda, Nobuyasu, Takehiko Osawa, Toshio Saito, Takatoshi Ogawa, and Takeshi Hiromatsu, inventors. "Apparatus for Purification of Waters with Titania Photocatalyst." Takenaka Komuten Co., Ltd., Japan, assignee. Japan Patent 09174046. 8 July 1997. 127:180866 CA.

446. Okumura, Katsuyoshi, inventor. "Apparatus for Ventilation and Denitration of Exhaust Gases from Road Tunnels.” Kurimoto, Ltd., Japan, assignee. Japan Patent 10323540. 2 December 1998. 130:42579 CA.

447. Omori, Akira, Dai Osato, and Takeshi Nagai, inventors. "Weather-Resistant Soil-Repellent Coating Composition Having Photocatalytic Capability and Coating Therewith." Daikin Industries, Ltd., Japan, assignee. Japan Patent 10195369. 28 July 1998. 129:176988 CA.

448. Omori, Masayoshi and Kosaku Nagashima, inventors. "UV-Resistant Sheets Having Surface Coatings Containing Photocatalysts.” Lintec Co., Ltd., Japan, assignee. Japan Patent 10128125. 19 May 1998. 128:328705 CA.

449. Ono, Haruo, Takeshi Matano, and Yoshiko Fujita, inventors. "Antimicrobial Laminated Polymer Sheets.” Dainippon Printing Co., Ltd., Japan, assignee. Japan Patent 09277463. 28 October 1997. 128:13985 CA.

450. Ono, Ryuji and Hiroshi Noguchi, inventors. "Fluid-Transporting Pipes Having PhotocatalystContaining Inner Coatings.” Ono, Ryuji, Japan, and Hiroshi Noguchi, assignees. Japan Patent 10103585. 21 April 1998. 128:276992 CA.

451. Ono, Yoshiyuki, Katsuhiro Sato, Eiichi Hirose, and Akira Imai, inventors. "Photoconductive Semiconductor Compositions and Their Manufacture.” Fuji Xerox Co., Ltd., Japan, assignee. Japan Patent 10041533. 13 February 1998. 128:169777 CA.

452. Oogami, Katsushi and Yuji Iguchi, inventors. "Deodorization Disinfection Sheets." Mitsubishi Paper Mills, Ltd., Japan, assignee. Japan Patent 10156141. 16 June 1998. 129:99205 CA.

453. Oohara, Shuzo, Hiroshi Kawahara, Masahiro Nakajima, Yoshinori Tanigami, and Soi Cho, inventors. "Long-Acting Deodorant Resin Compositions." Goyo Shiko Kk, Japan, and Yamamura Glass Co Ltd, assignees. Japan Patent 09031335. 4 February 1997. 126:226008 CA.

454. Ooka, Chihiro, inventor. "Crystalline Titania Particle-Clay Composites and Their Manufacture." Nagoya City, Japan, assignee. Japan Patent 10245226. 14 September 1998. 129:247245 CA. 
455. Oono, Takashi and Hiroshi Noguchi, inventors. "Apparatus for Cleaning Food Containers and Processors.” Japan, assignee. Japan Patent 10216665. 18 August 1998. 129:236179 CA.

456. Ooshima, Kenji, Takayoshi Takamoto, Takashi Nagai, and Kunishige Inada, inventors. "Manufacture of Titanium Oxide Photocatalyst Powder for Paint and Building Materials." Furukawa Kikai Kinzoku K.K., Japan, and Tope K.K., assignees. Japan Patent 10230169. 2 September 1998. 129:250786 CA.

457. Origasa, Toshiyuki, Eiichiro Yokochi, and Yasuo Nakai, inventors. "Synthetic Resin Moldings and Articles with Photocatalyst Function.” Dainippon Printing Co., Ltd., Japan, assignee. Japan Patent, 10156988. 16 June 1998. 129:109893 CA.

458. Orii, Kazunori, Shiro Kumakawa, Yasuyuki Yamazaki, and Kenji Baba, inventors. "Deodorizing and Antimicrobial Polyester Fiber Products.” Teijin Ltd., Japan, assignee. Japan Patent 10259521. 29 September 1998. 129:277335 $C A$.

459. Ota, Kazunobu, Takahiro Doi, and Yoshimasa Yamamoto, inventors. "Acrylic-Modified SiloxaneCoated Metal Products.” Sekisui Jushi Co., Ltd., Japan, assignee. Japan Patent 10291276. 4 November 1998. 130:14976 CA.

460. Oura, Setsuko, Katsuhisa Osaki, and Shigetoshi Suzuki, inventors. "Method for Manufacture of OilCapture Filter Capable of Decomposing Oil Using Titania Photocatalyst.” Nisshin Steel Co., Ltd., Japan, assignee. Japan Patent 10005513. 13 January 1998. 128:144591 CA.

461. Ozugi, Takashi and Satoshi Tamaki, inventors. "Manufacture of Functional Material Having Photocatalytic Property.” Sekisui Chemical Co., Ltd., Japan, assignee. Japan Patent 10156190. 16 June 1998. 129:101856 CA.

462. Pappa, Rosario and Edoardo D'Angeli, inventors. "Photocatalytic Treatment of Wastewater Polluted by Tetrahydrothiophene.” Enitecnologie S.p.A., Italy, assignee. Europe Patent 882674. 9 December 1998. 130:42776 CA.

463. Peebles III, Henry G., Steven K. Gorman, and Harkey William C., inventors. "Apparatus and Method for Photocatalytic Treatment of a Fluid.” American Energy Technologies, Inc., assignee. United States Patent 5,449,466. 12 September 1995.

464. Poncelet, Olivier Jean Christian and Danielle Marie H. Wettling, inventors. "Inorganic Trans- parent Photocatalytic Composition.” Eastman Kodak Company, USA, assignee. Europe Patent 812619. 17 December 1997. 128:95272 CA.

465. Pratsinis, Sotiris Emmanuel, Srinivas Vemury, George P. Fotou, and Andreas Gutsch, inventors. "Process for Producing Titanium Dioxide Ceramic Powder Useful as Photocatalyst." University of Cincinnati, USA, and Universität Karlsruhe, Germany assignees. United States Patent 5698177. 16 December 1997. 128:77210 CA.

466. Ritchie, David G. and Michael K. Robertson, inventors. "Fluid Purification - Continuous Oxygenation of Photocatalytic Reactor." David G. Ritchie, and Michael K. Robertson, assignees. Canada Patent 2147786. 26 October 1996. 126:176279 CA.

467. Sahara, Takashi, Toshiji Otsuka, and Yuji Ekuchi, inventors. "Photocatalytic Materials with 
Antisoiling, Deodorizing, and Antibacterial Properties.” Sekisui Chemical Co., Ltd., Japan, assignee. Japan Patent 10305091. 17 November 1998. 130:53766 CA.

468. Saito, Akiko and Hisashi Honda, inventors. "Glass Molded Bodies with Good Photocatalyst Function and Mechanical Strength for Lighting Devices.” Toshiba Lighting and Technology Corp., Japan, assignee. Japan Patent 09100140. 15 April 1997. 127:38499 CA.

469. Saito, Akiko and Hiroshi Kamata, inventors. "Glass for Photocatalyst, Glass Product, Electric Bulbs, Discharge Lamp, Illumination Articles and Water Treatment Equipment.” Toshiba Lighting and Technology Corp., Japan, assignee. Japan Patent 09315837. 9 December 1997. 128:52025 CA.

470. Saito, Akiko, Miho Saito, Hisashi Pponda, Juichi Sakakibara, and Keiji Hatakeyama, inventors. "Incandescent Lamp Bulb Coated with Photocatalyst." Toshiba Lighting \& Technology, Japan, assignee. Japan Patent 08273631. 18 October 1996. 126:83328 CA.

471. Saito, Izumi, Koji Ishikawa, Kenji Murakami, and Kenichi Sakuma, inventors. "Deodorization Systems Using Photocatalysts.” NHK Spring Co. Ltd., Japan, assignee. Japan Patent 08224292 A2. 3 September 1996. 125:337755 CA.

472. Saito, Izumi and Makoto Yumino, inventors. "Air Purification Machine Using Photocatalyst for Deodorization.” NHK Spring Co., Ltd., Japan, assignee. Japan Patent 10118519. 12 May 1998. 129:31636 CA.

473. Saito, Miho and Kunio Yuasa, inventors. "Apparatus for Lighting and Deodorization of Refrigerator Using Fluorescent Lamp.” Toshiba Lighting and Technology Corp., Japan, assignee. Japan Patent 09203582. 5 August 1997. 127:168849 CA.

474. Saito, Noriyoshi, Kazunori Saito, Hisashi Honda, Tsutomu Watanabe, Hiroshi Kamata, Akira Fujishima, and Kazuhito Hashimoto, inventors. "Compositions for Forming Thin Titanium Oxide Films and Photocatalysts." Nippon Soda Co., Ltd., Japan, and Toshiba Lighting and Technology Corp., assignees. Japan Patent 09248467. 22 September 1997. 127:310905 CA .

475. Saito, Toshio, inventor. "Real-Time Inspection of Photocatalyst Film on Constructions Using Photographic Device.” Takenaka Komuten Co., Ltd., Japan, assignee. Japan Patent 10206334. 7 August 1998. 129:128899 CA.

476. Saito, Toshio, Takatoshi Ogawa, and Nobuyasu Okuda, inventors. "Manufacture of Inorganic Particles Containing Photocatalyst for Painting and Water Purification.” Takenaka Komuten Co, Japan, assignee. Japan Patent 09066238. 11 March 1997. 126:308613 CA.

477. Sakaguchi, Seiichi, Yukinori Muraoka, and Mitsutoshi Murase, inventors. "Undercoating Materials for Forming Titania Photocatalyst Layers on Glass Substrates and Method for Forming Undercoating Layers.” Asahi Chemical Co., Japan, assignee. Japan Patent 10053439. 24 February 1998. 128:247485 CA.

478. Sakai, Atsuko, inventor. "Cupboards Having Food Storage Functions." Sharp Corp., Japan, assignee. Japan Patent 09215539. 19 August 1997. 127:189886 CA.

479. Sakai, Kazuhiro and Tadanobu Iwasa, inventors. "Photocatalyst Apparatus Having Light-Emitting Diode for Deodorization, Etc.” Toyoda Gosei Co., Ltd., Japan, assignee. Japan Patent 09299456. 25 November 1997. 128:26336 CA. 
480. Sakai, Kazuhiro, Tadanobu Iwasa, and Osamu Yamanaka, inventors. "Photo-Catalytic Device with Titania Film for Purification of Air and Water.” Toyoda Gosei Kk, Japan, assignee. Japan Patent, 09000940. 7 January 1997. 126:190684 CA.

481. Sakai, Kazuhiro, Tadanobu Iwasa, and Osamu Yamanaka, inventors. "LED Packages." Toyoda Gosei Kk, Japan, assignee. Japan Patent 09008361. 10 January 1997. 126:178753 CA.

482. Sakai, Takenobu, inventor. "Photocatalyst Supported on Silica." Toyota Motor Corp., Japan, assignee. Japan Patent 10151355. 9 June 1998. 129:34390 CA.

483. Sakai, Takeshi, inventor. "Decorative Deodorant Construction Sheets with ZnO-Supporting Photocatalyst Layers.” Dantani Plywood Co., Ltd., Japan, assignee. Japan Patent 10235802. 8 September 1998. 129:176725 CA.

484. Sakane, Yasuaki, inventor. "Air Purifying Apparatus Containing Dust Collectors." Sharp Corp., Japan, assignee. Japan Patent 09206628. 12 August 1997. 127:180367 CA.

485. Sakane, Yasuaki, inventor. "Photocatalyst-Containing Coatings for Air Purification." Sharp Corp., Japan, assignee. Japan Patent 09249824. 22 September 1997. 127:308533 CA.

486. Sakano, Susumu, Kanji Kinameri, Hisashi Miyashita, Akihiro Dobashi, Shinichi Ichikawa, and Yoshinori Furukawa, inventors. "Manufacture of Ring Fluorescent Lamps Having Photocata- lysts." Hitachi, Ltd., Japan, assignee. Japan Patent 10241559. 11 September 1998. 129:284735 CA.

487. Sakata, Akira, Atsushi Takamatsu, and Takeshi Kondo, inventors. "Low-Reflection Glasses Having Self Cleaning Property on the Surface." Central Glass Co., Ltd., Japan, assignee. Japan Patent 10045435. 17 February 1998. 128:171159 CA.

488. Sako, Toshiharu, Shoji Nakagawa, and Manabu Mizobuchi, inventors. "Apparatus for Deodorization of Sulfur Compound-Containing Gases.” Matsushita Electric Works, Ltd., Japan, assignee. Japan Patent 10192644. 28 July 1998. 129:112724 CA.

489. Sako, Toshiharu, Shoji Nakagawa, and Manabu Mizofuchi, inventors. "Biodegradable Thermoplastic Resin Moldings and Their Waste Treatment." Matsushita Electric Works, Ltd., Japan, assignee. Japan Patent 09309959. 2 December 1997. 128:35784 CA.

490. Sako, Toshiji, Naoharu Nakagawa, and Koichi Takahama, inventors. "Air-Purifying Method to Remove Harmful Components and Malodorous Components by Using Photocatalyst." Matsushita Electric Works Ltd, Japan, assignee. Japan Patent 08257364 A2. 8 October 1996. 126:36376 CA.

491. Sako, Toshiji, Naoharu Nakagawa, and Koichi Takahama, inventors. "Photocatalyst-Containing Composite Membranes for Purification of Air or Water.” Matsushita Electric Works Ltd, Japan, assignee. Japan Patent 08266904 A2. 15 October 1996. 126:36389 CA.

492. Sakuramoto, Takafumi, Masakatsu Urairi, Masakazu Sugimoto, and Tadanori Domoto, inventors. "Functional Porous Resin Films and Their Manufacture." Nitto Denko Corp., Japan, assignee. Japan Patent 09278928. 28 October 1997. 127:319836 CA.

493. Sasaki, Takayoshi, Jun Watanabe, Toshiyuki Mori, and Shoichi Sannai, inventors. "Titania Photocatalysts for Removing Organic Halo Compounds in Water and Removing Method." Kagaku Gijutsucho Mukizai, Japan, and Tosoh Corp., assignees. Japan Patent 10015392. 20 January 1998. 
128:119387 CA.

494. Sato, Koji, inventor. "Photoactive Water Treatment Agents and Containers for Them." Suisho Y.K., Japan, assignee. Japan Patent 10034143. 10 February 1998. 128:171915 CA.

495. Sato, Michihiko and Kazuchiyo Takaoka, inventors. "Photoreactive Material for Removal of Harmful Substances from Air.” Mitsubishi Paper Mills, Ltd., Japan, assignee. Japan Patent 09201404. 5 August 1997. 127:166025 CA.

496. Sato, Shigeo, Kimiichi Shimizu, and Norimasa Yoshino, inventors. "Apparatus for Measurement of Water Quality.” Meidensha Electric Mfg. Co., Ltd., Japan, assignee. Japan Patent 10142141. 29 May 1998. 129:32081 CA.

497. Sawara, Terutaka and Akio Tanaka, inventors. "Treatment of Waste Gases by UV Irradiation and Photocatalysts.” Hitachi Plant Engineering and Construction Co., Ltd., Japan, assignee. Japan Patent 09136017. 27 May 1997. 127:39003 CA.

498. Say, James, Roger Bonnecaze, Adam Heller, Steven Sitkiewitz, Ephraim Heller, and Paul Haugsjaa, inventors. "Apparatus for Photocatalytic Fluid Purification." E. Heller \& Co., USA, assignee. World Patent 9817390. 30 April 1998. 128:328701 CA.

499. Sayama, Kazuhiro, Hitoshi Kusama, Kiyomi Okabe, and Hironori Arakawa, inventors. "Semiconductor Photocatalyst and Photocatalytic Reaction Using It." Agency of Industrial Sciences and Technology, Japan, assignee. Japan Patent 09075745. 25 March 1997. 127:25778 CA.

500. Seguchi, Masashige, inventor. "Slit Fibers Having Beautiful Appearances and Photocatalytic Properties.” Oike Kogyo K.K., Japan, assignee. Japan Patent 10168689. 23 June 1998. 129:68807 $C A$.

501. Seki, Katsuhiko and Tetsuo Yamada, inventors. "Deodorant Carpets Containing Photolysis Catalysts.” Asahi Chemical Industry Co., Ltd., Japan, assignee. Japan Patent 10028640. 3 February 1998. 128:168710 CA.

502. Seki, Katsuhiko and Tetsuo Yamada, inventors. "Leafy Artificial Plants with Air Deodorization Ability.” Asahi Chemical Industry Co., Ltd., Japan, assignee. Japan Patent 10028723. 3 February 1998. 128:144604 CA.

503. Seki, Katsuhiko and Tetsuo Yamada, inventors. "Fabrics with Lasting Odor Absorption Prop- erties and Good Tear Strength." Asahi Chemical Industry Co., Ltd., Japan, assignee. Japan Patent 10037066. 10 February 1998. 128:205852 CA.

504. Seki, Katsuhiko and Tetsuo Yamada, inventors. "Deodoring Pile Fabrics and Their Manufacture." Asahi Chemical Industry Co., Ltd., Japan, assignee. Japan Patent 10053919. 24 February 1998. 128:205889 CA.

505. Seki, Katsuhiko and Tetsuro Yamada, inventors. "Method for Dyeing of Fabrics Containing Deodoring Fibers.” Asahi Chemical Industry Co., Ltd., Japan, assignee. Japan Patent 10053977. 24 February 1998. 128:205860 CA.

506. Sengoku, Makoto, Makoto Hayakawa, Toshiya Watabe, Masahiro Furuya, Masaaki Yamaya, and Akira Yamamoto, inventors. "Semipermanently Hydrophilic Photocatalytic Coating Compositions, Forming Coatings therefrom, and Self Cleaning, Fouling Prevention, and Coated Products Using the 
Same.” Toto Ltd., Japan, and Ltd. Shin-Etsu Chemical Industry Co., assignees. Japan Patent 09227829. 2 September 1997. 127:264335 CA.

507. Shibahara, Kazuo, Hideyuki Nakano, and Toshikatsu Takano, inventors. "Photolysis Catalysts Containing Copper Compounds for Air Treatment and Their Manufacture." Nippon Insulation Kk, Japan, assignee. Japan Patent 08294628. 12 November 1996. 126:94021 CA.

508. Shibata, Kazushige, inventor. "Photocatalyst-Containing Adhesion Tapes." Nitto Denko Corp., Japan, assignee. Japan Patent 10237397. 8 September 1998. 129:246242 CA.

509. Shibata, Kazushige, inventor. "Storage of Photocatalyst-Containing Tape." Nitto Denko Corp., Japan, assignee. Japan Patent 10263410. 6 October 1998. 129:283372 CA.

510. Shibata, Kazushige, inventor. "Storage of Laminated Photocatalyst Tape Having UltravioletShielding Layer.” Nitto Denko Corp., Japan, assignee. Japan Patent 10273178. 13 October 1998. 129:283373 CA.

511. Shibata, Kazushige, Shosuke Sano, and Masaaki Arakawa, inventors. "Deodorant Sheet for Toilet Use.” Nitto Denko Corp., Japan, assignee. Japan Patent 10005319. 13 January 1998. 128:144595 $C A$.

512. Shibata, Satoshi, Fumiaki Goto, Kozo Tanaka, Masao Minobe, Kiminari Nakamura, and Teizo Hanamura, inventors. "Antireflective Filter." Sumitomo Chemical Co, Japan, assignee. Japan Patent 08220305 A2. 30 August 1996. 125:312105 CA.

513. Shibuya, Yuichi, Yoshihiro Kohata, Hiroyuki Taoge, and Takashi Ohta, inventors. "Air-Deodorizing Apparatus Containing Fluidized and Circulating Titanium Dioxide Adsorbent Photocatalysts." Toyo Seisakusho K.K., Japan, assignee. Japan Patent 10314544. 2 December 1998. 130:6928 CA.

514. Shimano, Yasuharu and Junsei Kaneho, inventors. "Fabrics with Good Resistance to Mildew and Soiling or Odor Built Up and Their Manufacture.” Komatsu Seiren Co., Japan, assignee. Japan Patent 10001879. 6 January 1998. 128:116254 CA.

515. Shimazaki, Kenzo, Rihei Kasai, and Shigeji Kobori, inventors. "Solidification of Photocatalyst at Room Temperature by Pozzolanic Reaction.” Okaya Electric Industry Co., Japan, assignee. Japan Patent 09075747. 25 March 1997. 127:25779 CA.

516. Shimizu, Kaoru, inventor. "Removal of Pollutants from Air Using a Photocatalyst Mounted on a Vehicle.” Matsushita Electric Industrial Co., Ltd., Japan, assignee. Japan Patent 09099219. 15 April 1997. 127:22946 CA.

517. Shimizu, Kaoru, inventor. "Method for Removing Contaminant from Air and Window by Using Photocatalyst-Coated Glass Plate." Matsushita Electric Industrial Co., Ltd., Japan, assignee. Japan Patent 09173783. 8 July 1997. 127:180355 CA.

518. Shimizu, Kaoru, inventor. "Sheets Having Photocatalysts, Antibacterial Materials, or Functional Materials." Matsushita Electric Industrial Co., Ltd., Japan, assignee. Japan Patent 09226058. 2 September 1997. 127:235480 CA.

519. Shimizu, Kaoru, inventor. "Titania as Photocatalyst Coated on Surface of Electronic Devices for Removing Contaminants and Deodorization.” Matsushita Electric Industrial Co., Ltd., Japan, assignee. Japan Patent 09252185. 22 September 1997. 127:322331 CA. 
520. Shimizu, Kaoru, inventor. "Functional Material-Containing Film Sheets for in-Mold Lamination Process, Their Manufacture, and in-Mold Laminated Injection Products from Them." Matsushita Electric Industrial Co., Ltd., Japan, assignee. Japan Patent 10282889. 23 October 1998. 129:303497 $C A$.

521. Shimizu, Kaoru, inventor. "Transfer Sheets, Polymeric, Ceramic, or Rubber Moldings Coated with in-Mold Transfer Printed Products from the Sheets, and Their Manufacture by Injection Molding." Matsushita Electric Industrial Co., Ltd., Japan, assignee. Japan Patent 10278072. 30 October 1998. 129:344256 CA.

522. Shimobayashi, Kotaro, inventor. "Silica-Coated Photocatalyst Particles, Their Manufacture, and Coating Composition Containing Them." Nitto Denko Corp., Japan, assignee. Japan Patent 10180115. 7 July 1998. 129:73969 CA.

523. Shinohara, Kiyoaki, Akira Tanaka, and Hitoshi Ishizawa, inventors. "Method for Producing Porous Titanium Oxide Films, the Thus Produced Porous Titanium Oxide Films, and Photocatalysts for Decomposing Nitrogen Oxide Gases.” Nikon Corp., Japan, assignee. Japan Patent 10130887. 19 May 1998. 129:46692 CA.

524. Shiraishi, Fumihide, inventor. "Three-Dimensionally Designed Titania Photocatalyst Reactor Having High Activity.” Shiraishi, Fumihide, Japan, and Showa Tetsuko K.K., assignees. Japan Patent 10015393. 20 January 1998. 128:108346 CA.

525. Shiraiwa, Kimio, Masashi Saigo, and Toshiharu Yagi, inventors. "Fluorescent Lamp with Photocatalyst Film and Luminescent Device Using It.” Toshiba Lighting \& Technology, Japan, assignee. Japan Patent 08273611 A2. 18 October 1996. 126:41539 CA.

526. So, Toshiyasu, Makoto Sato, Hiroshi Kawahara, and Shuzo Ohara, inventors. "Blinds, Louvers, and Curtains Using Coated Titania Photocatalyst for Deodorization.” Goyo Shiko K.K., Japan, assignee. Japan Patent 09206200. 12 August 1997. 127:180365 CA.

527. So, Toshiyasu, Makoto Sato, Hiroshi Kawahara, and Shuzo Ohara, inventors. "Interior Decorative Articles Having Deodorizing Function.” Goyo Shiko K.K., Japan, assignee. Japan Patent 09209208. 12 August 1997. 127:222349 CA.

528. Soma, Ryuji, Hisashi Honda, Ariyoshi Ishizaki, Tsutomu Watanabe, Hiroshi Kamata, Akiko Saitou, and Akimasa Endou, inventors. "Photocatalyst, Light Source and Lighting Device." Toshiba Lighting \& Technology Corp., Japan, Nihon Doro Kodan-Japan Highway Public Corp., Ryuji Soma, Hisashi Honda, Ariyoshi Ishizaki, Tsutomu Watanabe, Hiroshi Kamata, Akiko Saitou, and Akimasa Endou, assignees. World Patent 9825700. 18 June 1998. 129:75238 CA.

529. Sooma, Ryuji, Akira Fujishima, Kazuhito Hashimoto, Shin Hayakawa, and Toshiya Watanabe, inventors. "Tunnel Inner Wall Coated with Photocatalyst for Preventing Contamination and Washing Method." Nippon Doro Kodan, Japan, and Toto Ltd., assignees. Japan Patent 10037688. 980210. Heisei. 10 February 1998. 128:208425 CA.

530. Sugawara, Satoko, Ichiro Nakamura, and Yasuaki Kai, inventors. "Antifogging Coating Materials, Antifogging Coating Films therefrom, and Their Manufacture.” Nissan Motor Co., Ltd., Japan, assignee. Japan Patent 09227158. 2 September 1997. 127:266942 CA.

531. Sugishima, Masami, Tadahiro Nakao, and Nobuto Hirata, inventors. "Aqueous Polish and Aqueous Clear Coatings and the Coatings for Reduction of Interior Pollution.” Kansai Paint Co., Ltd., Japan, 
assignee. Japan Patent 10251565. 22 September 1998. 129:291226 CA.

532. Sugishima, Masami, Tadahiro Nakao, Nobuto Hirata, and Nobushige Numa, inventors. "Interior Pollution-Resistant Coating Materials." Kansai Paint Co., Ltd., Japan, assignee. Japan Patent 10183023. 7 July 1998. 129:162913 CA.

533. Sugiyama, Tamotsu, inventor. "Surface-Coarsened Macromolecular Moldings with High Antibacterial or Deodorizing Activity." Aloban K.K., Japan, assignee. Japan Patent 09309957. 2 December 1997. 128:14021 CA.

534. Sugiyama, Tamotsu, inventor. "Manufacture of Porous Biscuits with Good Deodorization and Antibacterial Functions.” Aroban K.K., Japan, assignee. Japan Patent 10059763. 3 March 1998. 128:208078 CA.

535. Suzue, Masayoshi, Minoru Aki, and Katsura Torii, inventors. "Photocatalyst, Process for Producing the Same and Multi-Functional Members.” Otsuka Kagaku K.K., Japan, assignee. World Patent 9843733. 8 October 1998. 129:281753 CA.

536. Suzuki, Akihisa, inventor. "Apparatus for Purification and Disinfection of Waters in Pool and Bath with Photocatalyst.” Brother Ind. Ltd., Japan, assignee. Japan Patent 08318267. 3 December 1996. 126:135416 CA.

537. Suzuki, Akihisa, inventor. "Pool Water and Bath Water Disinfecting Systems." Brother Ind. Ltd., Japan, assignee. Japan Patent 09029258. 4 February 1997. 126:242536 CA.

538. Suzuki, Kenichiro, Noriaki Sugimoto, Masato Sugiura, Masaharu Noda, Hideki Ono, and Miho Matsuo, inventors. "Glass Material Having Metal Oxide Thin Film with Photocatalytic Activity." Toyota Central Research and Development Laboratories, Inc., Japan, and Toyota Motor Corp., assignees. Japan Patent 09235140. 9 September 1997. 127:266927 CA.

539. Suzuki, Masayuki, Toshikazu Suzuki, Eigo Nakajima, and Sadao Kuroki, inventors. "Deodorizing Dish Towels Containing Photocatalyst Coatings.” Suzutora Seisen Kojo Co., Ltd., Japan, assignee. Japan Patent 10216210. 18 August 1998. 129:206499 CA.

540. Suzuki, Mitsuo and Hiroyuki Aikyo, inventors. "Manufacture of Activated Carbon with Improved Photocatalytic Activity." Mitsubishi Chemical Industries Ltd., Japan, assignee. Japan Patent 10033989. 10 February 1998. 128:169365 CA.

541. Suzuki, Mitsuo and Satoshi Hirahara, inventors. "Activated Carbon Having Antibacterial Effects under or without Light Radiation Used as Adsorbents for Water and Gas Treatment." Mitsubishi Chemical Industries Ltd., Japan, assignee. Japan Patent 10265209. 6 October 1998. 129:264679 $C A$.

542. Suzuki, Mitsuo and Satoshi Hirahara, inventors. "Manufacture of Antibacterial Activated Carbon Showing Photocatalytic Activities." Mitsubishi Chemical Industries Ltd., Japan, assignee. Japan Patent 10272368. 13 October 1998. 129:292962 CA.

543. Tabatabaie-raissi, Ali, Nazim Z. Muradov, and Iii Philip W. Fairey, inventors. "Method for Photocatalytic Destruction of Harmful Volatile Compounds at Emitting Surfaces." University of Central Florida, USA, assignee. United States Patent 5604339. 18 February 1997. 126:175995 CA.

544. Tabuchi, Toshiyuki, inventor. "Air-Conditioning Apparatus Equipped with Deodorization and Anti- 
Bacterial Function.” Diamond Electric Mfg. Co., Ltd., Japan, assignee. Japan Patent 10185228. 14 July 1998. 129:112721 CA.

545. Tada, Hiroaki and Hisao Pponda, inventors. "Articles Carrying Photolysis Catalysts and Reactors for Highly Efficient Photolysis.” Nippon Itagarasu Tekuno Risaac, Japan, and Nippon Sheet Glass Co. Ltd., assignees. Japan Patent 08257410 A2. 8 October 1996. 126:36377 CA .

546. Tada, Hiroaki and Koji Shimoda, inventors. "Manufacture of Hydrophilic Polyolefin Articles for Battery Separator Use.” Nippon Itagarasu Tekuno Risaac, Japan, and Nippon Glass Fiber Co. Ltd., assignees. Japan Patent 09059403. 4 March 1997. 126:278698 CA.

547. Tada, Hiroaki, Koji Shimoda, Akihiko Hattori, Kazuhiro Doushita, and Takashi Sunada, inventors. "Nonfogging and Stainproof Glass Articles." Nippon Sheet Glass Co., Ltd., Japan, Ltd. NSG Techno-Research Co., Hiroaki Tada, Koji Shimoda, Akihiko Hattori, Kazuhiro Doushita, and Takashi Sunada, assignees. World Patent 9827021. 25 June 1998. 129:71030 CA.

548. Tada, Hiroaki, Koji Shimoda, Toshiya Ito, and Akihiko Hattori, inventors. "Method for Manufacture of Semiconductor Photocatalyst Containing Fluorine for Air Purification.” Ltd. Japan Nippon Sheet Glass Co., Ltd. NSG Techno-Research Co., Hiroaki Tada, Koji Shimoda, Toshiya Ito, and Akihiko Hattori, assignees. World Patent 9805413. 12 February 1998. 128:184076 CA.

549. Tahara, Hideo, Yoshihiko Murata, Hiroshi Kohata, and Kyoshi Kamiya, inventors. "Material for Removing Hazardous or Toxic Compounds." Mitsubishi Materials Corp., Japan, assignee. Japan Patent 10272355. 13 October 1998. 130:8838 CA.

550. Tahara, Hideo, Yoshihiko Murata, Tadashi Matsumoto, Kiyoshi Kamiya, Hiroshi Ohata, and Hiroshi Yamada, inventors. "Material for Removing Hazardous or Toxic Compounds and Process of Manufacture Therefor.” Mitsubishi Materials Corp., Japan, assignee. Japan Patent 10272356. 13 October 1998. 130:8839 CA.

551. Tahara, Hideo, Yoshihiko Murata, and Hiroshi Ohata, inventors. "Materials for Removal of Toxic Substances and Their Manufacture.” Mitsubishi Materials Corp., Japan, assignee. Japan Patent 10225619. 25 August 1998. 129:179495 CA.

552. Tahara, Hideo, Hidenori Sekito, Yoshihiko Murata, and Hiroshi Ohata, inventors. "Coated CementBased Materials for NOx Removal.” Mitsubishi Materials Corp., Japan, assignee. Japan Patent 10290924. 4 November 1998. 129:320200 CA.

553. Tahara, Hideo, Hidenori Sekito, Yoshihiko Murata, and Hiroshi Kohata, inventors. "Photocata- lytic Material for Harmful Substance Removal from Water and Production of the Material." Mitsubishi Materials Corp., Japan, assignee. Japan Patent 10290980. 4 November 1998. 129:306275 CA.

554. Tahara, Hideo, Keishi Tobinai, Yoshihiko Murata, and Hiroshi Ohata, inventors. "Cleaning of Titania-Containing Cement Materials for Removal of Nitrogen Oxide from Waste Gases." Mitsubishi Materials Corp., Japan, assignee. Japan Patent 10225621. 25 August 1998. 129:179471 $C A$.

555. Tahara, Teruo, Yoshihiko Murata, and Hiroshi Ohata, inventors. "Manufacture of Materials for NOx Removal.” Mitsubishi Materials Corp., Japan, assignee. Japan Patent 10043549. 17 February 1998. 128:158276 CA. 
556. Takada, Munetake, Masami Takagi, Miho Saito, and Katsunobu Usui, inventors. "Fluorescent Lamp for Irradiation of Photocatalyst and Sterilizing Apparatus." Toshiba Lighting and Technology Corp., Japan, assignee. Japan Patent 10154488. 9 June 1998. 129:89061 CA.

557. Takagi, Masami, inventor. "Photocatalysts and Air Purification Apparatus." Toshiba Lighting and Technology Corp., Japan, assignee. Japan Patent 10235202. 8 September 1998. 129:192988 CA.

558. Takahama, Koichi, Hirotsugu Kishimoto, Takaharu Nakagawa, Shigehito Deki, and Noboru Hashimoto, inventors. "Substrates with Titanium Dioxide Films Having Photocatalytic Activity." Matsushita Electric Works, Ltd., Japan, assignee. Europe Patent 784034. A1. 16 July 1997. 127:98753 CA.

559. Takahama, Koichi, Naoharu Nakagawa, and Koji Kishimoto, inventors. "Metal-Doped Photocatalyst with Good Sensitivity for Visible Light and Self-Cleaning Items Using It." Matsushita Electric Works, Ltd., Japan, assignee. Japan Patent 09192496. 29 July 1997. 127:128654 CA.

560. Takahama, Koichi, Naoharu Nakagawa, and Koji Kishimoto, inventors. "Photocatalyst Having Magnesia-Based Support.” Matsushita Electric Works, Ltd., Japan, assignee. Japan Patent 09192497. 29 July 1997. 127:142726 CA.

561. Takahama, Koichi, Naoharu Nakagawa, and Koji Kishimoto, inventors. "Lighting Device with Titania Photocatalyst for Preventing Contamination from Air." Matsushita Electric Works, Ltd., Japan, assignee. Japan Patent 09198907. 31 July 1997. 127:224581 CA.

562. Takahama, Koichi, Toshiji Sako, and Naoharu Nakagawa, inventors. "Method for Carrying Photocatalyst." Matsushita Electric Works Ltd, Japan, assignee. Japan Patent 08257411 A2. 8 October 1996. 126:64453 CA.

563. Takahama, Koichi, Toshiji Sako, and Naoharu Nakagawa, inventors. "Porous Adsorbents for Removal of Odor from Air." Matsushita Electric Works Ltd, Japan, assignee. Japan Patent 08259344 A2. 8 October 1996. 126:36379 CA.

564. Takahama, Koichi, Toshiji Sako, Naoharu Nakagawa, Keimei Kitamura, and Makoto Yamada, inventors. "Manufacture of Titanium Oxide Photocatalyst Membranes for Purification of Air or Water." Matsushita Electric Works Ltd., Japan, assignee. Japan Patent 08266910 A2. 15 October 1996. 126:36390 CA.

565. Takahashi, Eiji, inventor. "Cationic Photocatalyst Composition.” Nippon Soda Co., Ltd., Japan, and Eiji Takahashi, assignees. World Patent 9812232. 26 March 1998. 128:231675 CA.

566. Takahashi, Kazuyoshi, inventor. "Water Treatment Process and Apparatus Using Photocatalysts." Sumitomo Heavy Industries, Ltd., Japan, assignee. Japan Patent 10249336. 22 September 1998. 129:235392 CA.

567. Takahashi, Takeo, Kiyotaka Sueyasu, Shuji Sekino, Satoshi Nishikata, and Isao Amano, inventors. "Apparatus Consisting of a Large Number of Photocatalyst Sheets for Removal of Harmful Gases." Fuji Electric Co., Ltd., Japan, assignee. Japan Patent 09131514. 20 May 1997. 127:38948 CA. 
568. Takahashi, Takeo, Kiyotaka Sueyasu, Shuji Sekino, Satoshi Nishikata, and Tomoaki Nishimura, inventors. "Apparatus for Removal of Harmful Gases Using Solar Cell as Light Source for Its Photolysis Catalyst.” Fuji Electric Co., Ltd., Japan, assignee. Japan Patent 09131513. 20 May 1997. 127:38947 CA.

569. Takahata, Eiji, inventor. "Antibacterial Filters for Air Filters for Clean Rooms." Nitto Denko Corp., Japan, assignee. Japan Patent 09313827. 9 December 1997. 128:38872 CA.

570. Takai, Kenichi, Hiroyuki Saito, and Goro Yamauchi, inventors. "Antifouling Fluoropolymer Coating and Coated Membrane from the Same." Nippon Telegraph and Telephone Corp., Japan, assignee. Japan Patent 10088061. 7 April 1998. 128:283660 CA.

571. Takai, Kenichi, Hiroyuki Saito, Goro Yamauchi, Toshinobu Ueda, and Takeshi Shimizu, inventors. "Two-Coat Powder Coatings, Their Compositions and Method of Coating." Nippon Telegraph and Telephone Corp., Japan, and NTT Advanced Technology K.K., assignees. Japan Patent 10130540. 19 May 1998. 129:55516 CA.

572. Takaoka, Kazucho, inventor. "Method for Removing Hazardous Materials from Gases, Especially Contaminated Air.” Mitsubishi Paper Mills Ltd., Japan, assignee. Japan Patent 08318130. 3 December 1996. 126:134991 CA.

573. Takaoka, Kazucho, Yasuyuki Oku, Katsushi Oogami, and Isao Ebihara, inventors. "Manufacture of Materials Containing Titanium Oxide for Removal of Hazardous Substances.” Mitsubishi Paper Mills Ltd., Japan, Fujishima Akira, and Hashimoto Kazuhito, assignees. Japan Patent 08266601 A2. 15 October 1996. 126:62232 CA.

574. Takaoka, Kazucho, Yasuyuki Oku, Katsushi Oogami, and Isao Ebihara, inventors. "Manufacture of Titania-Containing Agent for Removing Hazardous Substances from Effluents." Mitsubishi Paper Mills Ltd., Japan, Fujishima Akira, and Hashimoto Kazuhito, assignees. Japan Patent 08266602 A2. 15 October 1996. 126:64430 CA.

575. Takehana, Toshihiro, Tooru Sakai, and Kenji Murakami, inventors. "Deodorization Device for Removal of Malodor Generated from Fresh Refuse Decomposition Apparatus.” NHK Spring Co. Ltd., Japan, assignee. Japan Patent 08206455 A2. 13 August 1996. 125:283669 CA.

576. Takemura, Tooru, Jun Kamo, and Michiharu Uenishi, inventors. "Manufacture of Photocatalyst Fiber Having Light-Leaking Section for Improving Decomposition of Hazardous Substances." Mitsubishi Rayon Co., Japan, assignee. Japan Patent 09000947. 7 January 1997. 126:190682 CA.

577. Takeshita, Kazutoshi, Shiro Nishi, Shigekuni Sasaki, Shigeyuki Tsurumi, Mikio Takashima, Shinji Tsudome, and Fumio Yamamoto, inventors. "Fuel Storage Tank Using Photocatalysts for Improving Fuel Properties.” Nippon Telegraph and Telephone Corp., Japan, assignee. Japan Patent 10176615. 30 June 1998. 129:83637 CA.

578. Takeshita, Yukitoshi, Shiro Nishi, Shigekuni Sasaki, Shigeyuki Tsurumi, Mikio Takeshima, Shinji Tsudome, and Fumio Yamamoto, inventors. "Resin Moldings with Good Resistance to Surface Soiling and Method for Manufacture." Nippon Telegraph and Telephone Corp., Japan, assignee. Japan Patent 10217388. 18 August 1998. 129:231668 CA.

579. Takeuchi, Hiroshi, Shuzo Kutsuna, Akitsugu Ibisuku, Shingo Sawano, and Izumi Fukumori, inventors. "Apparatus for Indoor Air Purification." Agency of Industrial Sciences and Technology, Japan, and Okitsumo K.K., assignees. Japan Patent 10066830. 10 March 1998. 128:234536 CA. 
580. Takeuchi, Yosuke, inventor. "Photocatalyst-Coated Molding Apparatus with Good Extrudate Releasability." Toto Ltd., Japan, assignee. Japan Patent 10034668. 10 February 1998. 128:155063 $C A$.

581. Takimoto, Kazutoshi, inventor. "Air Cleaner with Illumination Function.” Sharp Corp., Japan, assignee. Japan Patent 09161537. 20 June 1997. 127:139602 CA.

582. Tamagawa, Katsuyasu, inventor. "Charcoal Containing Titanium Dioxide and Its Molded Product as Environmental Pollutant Treatment Material.” Nara Tanka Kogyo K.K., Japan, assignee. Japan Patent 09239268. 16 September 1997. 127:283151 CA.

583. Tamaki, Satoshi and Takashi Oosugi, inventors. "Photocatalytic Functional Materials and Manufacture Methods Therefor.” Sekisui Chemical Co., Ltd., Japan, assignee. Japan Patent 10101821.21 April 1998. 128:309539 CA.

584. Tamaki, Satoshi and Takashi Osugi, inventors. "Manufacture of Thin Film Having Photocatalytic Activity by Sol-Gel Processing." Sekisui Chemical Co., Ltd., Japan, assignee. Japan Patent 10235203. 8 September 1998. 129:195739 CA.

585. Tamaki, Satoshi, Takashi Osugi, Tsutomu Minami, and Masahiro Tatsumisago, inventors. "Manufacture of Photocatalytic Thin Film by Photocuring Sol-Gel Method." Sekisui Chemical Co., Ltd., Japan, assignee. Japan Patent 10249211. 22 September 1998. 129:237619 CA.

586. Tamaru, Shinji, Katsutoshi Yamamoto, and Toshio Kusumi, inventors. "Apparatus for Supplying Purified Air and Their Gas-Permeable Components.” Daikin Industries, Ltd., Japan, assignee. Japan Patent 10286437. 27 October 1998. 129:346750 CA.

587. Tamaru, Shinji, Katsutoshi Yamamoto, Toshio Kusumi, and Jun Asano, inventors. "Filtering Materials with Photocatalyst Function and Air Filter Unit Using Same." Daikin Industries, Ltd., Japan, assignee. World Patent 9831451. 23 July 1998. 129:124169 CA.

588. Tanabe, Hironari, Toru Taki, Yoshiyuki Iwase, and Shunsuke Nakayama, inventors. "Aquatic Antifouling Coating Compositions Comprising Photocatalytic Metal Oxide Powders." Dainippon Toryo Co., Ltd., Japan, assignee. Japan Patent 10204335. 4 August 1998. 129:190540 CA.

589. Tanaka, Hiroko, Hiromasa Ogawa, and Hitoshi Okinaka, inventors. "Titania-Containing Silica Photocatalysts Having Three-Dimensional Network Structures and Their Manufacture.” Agency of Industrial Sciences and Technology, Japan, and Ltd. Rasa Industries, assignees. Japan Patent 10277400. 20 October 1998. 129:293353 CA.

590. Tanaka, Isao, Tomoaki Kajima, Nobuo Suzuki, and Yoshinob Suzuki, inventors. "Materials Containing Photocatalysts and Process for Out Gas Generation Prevention." Shimizu Construc- tion Co., Ltd., Japan, assignee. Japan Patent 10230133. 2 September 1998. 129:206501 CA.

591. Tanaka, Kazuhiko, Kazumasa Kusudo, Hiroshi Ito, Masao Kawamoto, and Masahiro Nakakawa, inventors. "Deodorant Synthetic Fibers with Lasting Antibacterial Odor Absorption Properties." Kuraray Co., Ltd., Japan, assignee. Japan Patent 10037023. 10 February 1998. 128:193676 CA.

592. Tanaka, Kazuhiko, Kyuji Kuwahara, Hiroshi Ito, Masao Kawamoto, and Junyo Nakakawa, inventors. "Heat-Fusible Fibers with Long-Lasting Deodorizing Properties." Kuraray Co., Ltd., Japan, assignee. Japan Patent 10183426. 14 July 1998. 129:123780 CA. 
593. Tanaka, Keiichi and Keiji Abe, inventors. "Treatment of Wastewater with Ozone and Photocatalysts." Agency of Industrial Sciences and Technology, Japan, assignee. Japan Patent 09075959. 25 March 1997. 127:23113 CA.

594. Tanaka, Keiichi, Teruaki Hisanaga, and Insei Chin, inventors. "Fixed Photocatalysts and Fixing Method for Detoxication of Harmful Substances.” Kogyo Gijutsuin, Japan, assignee. Japan Patent 08318166. 3 December 1996. 126:121928 CA.

595. Tanaka, Satoru, inventor. "Self-Cleaning Glass Blocks for Building Walls and Roofs." Tanaka, Satoru, Japan, assignee. Japan Patent 10053436. 24 February 1998. 128:183731 CA.

596. Tanaka, Shigeru and Yuichi Komazaki, inventors. "Nitrogen Oxide Sampler for Measuring Concentration of Nitrogen Oxide in Air." Shimadzu Corp., Japan, assignee. Japan Patent 10253508. 25 September 1998. 129:325543 CA.

597. Tanaka, Takayoshi, inventor. "Air-Deodorizing Apparatus Containing Fluidized and Circulated Titanium Dioxide Photocatalysts.” Toyo Seisakusho K.K., Japan, assignee. Japan Patent 10314543. 2 December 1998. 130:6927 CA.

598. Tani, Naoki, inventor. "Ice Machine in Refrigerator." Sharp Corp., Japan, assignee. Japan Patent 09225457. 2 September 1997. 127:238856 CA.

599. Taoda, Hiroshi, inventor. "Deodorizing and Antimicrobial Titanium Oxide-Coated Organic Sheets." Agency of Industrial Sciences and Technology, Japan, assignee. Japan Patent 09111022. 28 April 1997. 127:55669 CA.

600. Taoda, Hiroshi, Kazumi Kato, Kazutomo Fujita, Shigemi Imaizumi, Yoshinori Sugawara, Hirokazu Kato, Kazuyuki Okumura, Yoshitaka Kawashima, and Norio Yamashita, inventors. "Durable Titania Photocatalyst Particles Suitable for Air and Water Purification, Deodorization, and Bactericides and Fungicides and Their Preparation.” Agency of Industrial Sciences and Technology, Japan, and Gifu Prefecture, assignees. Japan Patent 09276706. 28 October 1997. 127:350487 CA.

601. Taoda, Hiroshi, Shunsaku Kato, and Shigekazu Kato, inventors. "Formation of Titanium Dioxide Coatings Using Supercritical Fluids.” Agency of Industrial Sciences and Technology, Japan, Kato Kikai Seisakusho K.K., Hiroshi Taoda, and Shunsaku Kato, assignees. Japan Patent 10194740. 28 July 1998. 129:128898 CA.

602. Taoda, Hiroshi, Susumu Nonami, Fujio Aramaki, and Shoshichi Aramaki, inventors. "Materials for Environmental Purification and Manufacture of the Materials." Agency of Industrial Sciences and Technology, Japan, and JME K.K., assignees. Japan Patent 10244166. 14 September 1998. 129:280719 CA.

603. Taoda, Hiroshi, Atsuya Towata, Mutsuo Santo, and Kazumi Kato, inventors. "Titania Photo- catalyst Particles Showing Excellent Handling Property and Their Preparation." Agency of Industrial Sciences and Technology, Japan, assignee. Japan Patent 09225319. 2 September 1997. 127:209642 $C A$.

604. Tatsuhara, Kiyoshi and Yoshimichi Yonekura, inventors. "Photocatalysts with Solar Cells." Mitsubishi Heavy Industries, Ltd., Japan, assignee. Japan Patent 10290017. 27 October 1998. 129:318670 CA.

605. Tawara, Osamu, Akira Fujishima, and Kazuhito Hashimoto, inventors. "Manufacture of Titanium 
Dioxide Photocatalyst with High Adhesion to Substrate." Fujishima, Akira, Japan, Kazuhito Hashimoto, and Shimadzu Corp., assignees. Japan Patent 09276694. 28 October 1997. 128:28560 $C A$.

606. Tobe, Ikuo and Takeshi Nagata, inventors. "Photocatalyst-Containing Aqueous Coating Materials Excellent Hiding and Self-Cleaning Properties and Building Materials Using the Same." Matsushita Electric Works, Ltd., Japan, assignee. Japan Patent 10237354. 8 September 1998. 129:277431 CA.

607. Togeda, Hiroshi and Kazumi Kato, inventors. "Porous Photocatalysts and Their Preparation." Kogyo Gijutsuin, Japan, assignee. Japan Patent 08196903 A2. 6 August 1996. 125:234285 CA.

608. Tomita, Yoshihiro, Kuniyasu Shiro, and Miyoshi Yokura, inventors. "Composite Photocatalyst with Extremely-High Catalyst Activity, Its Manufacture, and Photocatalytic Substance Having the Same on Surface.” Toray Industries, Inc., Japan, assignee. Japan Patent 10263412. 6 October 1998. 129:267822 CA.

609. Tomonari, Masanori, Satoyuki Hirota, and Yoshiki Kinoshita, inventors. "Photocatalysts and Their Manufacture for Air Deodorization.” Ishihara Sangyo Kaisha, Japan, assignee. Japan Patent 08182934 A2. 16 July 1996. 125:229476 CA.

610. Towata, Atsuya, and Mutsuo Santo, inventors. "Magnetic Force-Recoverable Granular Photocatalysts and Preparation Thereof." Kogyo Gijutsuin, Japan, assignee. Japan Patent 09066237. 11 March 1997. 126:283254 CA.

611. Tsuchii, Yorio, inventor. "Water-Base Paint Compositions for Forming Nitrogen OxideDecomposing Coatings." Kansai Paint Co., Ltd., Japan, assignee. Japan Patent 10195333. 28 July 1998. 129:140055 CA.

612. Uchida, Hiroyuki and Masahiro Watanabe, inventors. "Thin Film Semiconductive Photolytic Catalysts for Decomposition of Harmful Substances and Reactors Using the Catalysts." Watanabe, Masahiro, Japan, and Hiroyuki Uchida, assignees. Japan Patent 09276707. 28 October 1997. 128:26334 CA.

613. Uchida, Isao, Akira Hasegawa, Yoshikata Uchiyama, and Masao Kando, inventors. "Bathtub Water Purification Apparatus.” Corona K.K., Japan, assignee. Japan Patent, 10202256. 4 August 1998. 129:166017 CA.

614. Uchida, Shigeo, Akinori Maezawa, and Masahiko Yano, inventors. "Apparatus for Wastewater Purification by UV Lamp and Titania Photocatalyst." Suzuki Co., Ltd., Japan, assignee. Japan Patent 09253640. 30 September 1997. 127:350937 CA.

615. Uenishi, Michiharu, Toru Takemura, and Jun Kamo, inventors. "Apparatus for Removal of Noxious Pollutants from Water or Air Using Photocatalyst Fibers.” Mitsubishi Rayon Co., Ltd., Japan, assignee. Japan Patent 09253505. 30 September 1997. 127:350962 CA.

616. Usami, Tsutomu, inventor. "Photocatalytic Aluminum Materials and Their Manufacture." Sumitomo Light Metal Industries, Ltd., Japan, assignee. Japan Patent 10174883. 30 June 1998. 129:85220 CA.

617. Wada, Hidenori, inventor. "Method and Apparatus for Photocatalytic Sterilization of Plant Culture Medium and Reactor Therefor." Nihon Filter Co., Ltd., Japan, assignee. Japan Patent 09327246. 22 December 1997. 128:72647 CA. 
618. Washizu, Ikue and Yasuko Kumano, inventors. "Building Material Using Photocatalyst for Air Purification.” Fujita Corp., Japan, assignee. Japan Patent 10152904. 9 June 1998. 129:71669 CA.

619. Watanabe, Mitsuru, Akira Fujishima, and Kazuhito Hashimoto, inventors. "Photocatalyst Powder, Photocatalyst Using the Powder, and Environmental Purification Method." Ishihara Sangyo Kaisha, Ltd., Japan, Akira Fujishima, and Kazuhito Hashimoto, assignees. Japan Patent 09239277. 16 September 1997. 127:267323 CA.

620. Watanabe, Mitsuru, Kazutoshi Sugitani, and Nobuyuki Myazaki, inventors. "Fluoropolymer Films with Long-Lasting Photocatalytic Function and Their Preparation." Ishihara Sangyo Kaisha, Japan, and Asahi Glass Co. Ltd., assignees. Japan Patent 08290516. 5 November 1996. 126:90410 CA.

621. Watanabe, Mitsuru, Koichi Yamaguchi, and Keiko Ikeda, inventors. "Photocatalyst for Removal of Nitrogen Oxides and Its Manufacture.” Ishihara Sangyo Kaisha, Ltd., Japan, assignee. Japan Patent 10174881. 30 June 1998. 129:127629 CA.

622. Watanabe, Shunya and Makoto Hayakawa, inventors. "Substrates Having Hydrophilicity and/ or Photocatalytic Activity.” Toto Ltd., Japan, assignee. Japan Patent 09314052. 9 December 1997. 128:90131 CA.

623. Watanabe, Toshiya, Mitsuhide Shimofukikoshi, Makoto Hayakawa, Akira Fujishima, and Kazuhito Hashimoto, inventors. "Hydrophilic Lipophilic Materials." Toto Ltd., Japan, assignee. Japan Patent 10166495. 23 June 1998. 129:82840 CA.

624. Watzke, Eckhart, Andrea Kaempfer, Martin Dr Roth, and Christine Hoffmeister, inventors. "Method and Reactor for Photochemical and Photobiological Processes Using Solar Energy, Useful for Drinking Water Disinfection.” Hans-Knoell-Institut fuer Naturstoff-Forschung e.V., Germany, Eckhart Watzke, and Andrea Kaempfer, assignees. Germany Patent 19532807. 27 February 1997. 126:242562 CA.

625. Yabe, Hideaki and Osamu Miki, inventors. "Method for Treatment of Acidic Wastewater from Steelmaking Using Iron-Oxidizing Bacteria." Nippon Steel Corp., Japan, assignee. Japan Patent 09141255. 3 June 1997. 127:113084 CA.

626. Yahagibe, Hideaki and Shingo Katayama, inventors. "Photocatalysts for Water Purification and Their Manufacture.” Nippon Steel Corp., Japan, assignee. Japan Patent 09299810. 25 November 1997. 128:79765 CA.

627. Yakabe, Hiroshi, Mitsuru Nakagawara, and Shiko Kim, inventors. "Soilproofing, Antibacterial, and Odorless Decorative Sheets.” Toppan Printing Co., Ltd., Japan, assignee. Japan Patent 10044361. 17 February 1998. 128:193540 CA.

628. Yamada, Ryoji, inventor. "Semiconductor Photocatalyst Composition.” Asahi Glass Co. Ltd., Japan, assignee. Japan Patent 08309203. 26 November 1996. 126:96791 CA.

629. Yamada, Ryoji, inventor. "Titania-Based Photocatalyst-Forming Agents, Photocatalysts there- from, and Glass Products Having Coatings Therefrom.” Asahi Glass Co., Ltd., Japan, assignee. Japan Patent 10128110. 19 May 1998. 129:34389 CA.

630. Yamada, Ryoji, inventor. "Photocatalyst Composition, Agent for Its Formation, and Substrate Coated with It." Asahi Glass Co., Ltd., Japan, assignee. Japan Patent 10165811. 23 June 1998. 129:60529 CA. 
631. Yamada, Ryoji, Iwakichi Sugiyama, and Hiroshi Suzuki, inventors. "Manufacture of Modified Titanium Oxide Sol for Photocatalyst Composition.” Asahi Glass Co. Ltd., Japan, assignee. Europe Patent 770579. A1. 2 May 1997. 126:319090 CA.

632. Yamaguchi, Toru and Isao Oikawa, inventors. "Domestic Electric Apparatus Equipped with Deodorization Function.” Toshiba Corp., Japan, and Toshiba Audio Visual Engineering K.K., assignees. Japan Patent 10227469. 25 August 1998. 129:165548 CA.

633. Yamamoto, Takeshi, Akiharu Goto, Minoru Inoue, and Junko Ikenaga, inventors. "Self-Cleaning Multilayer Silicone Transfer Films and Transferred Articles." Matsushita Electric Works, Ltd., Japan, assignee. Japan Patent 10157021. 16 June 1998. 129:110209 CA.

634. Yamamura, Kenji, inventor. "Apparatus and Method for Water Treatment Using Photocatalysts." Sumitomo Heavy Industries, Ltd., Japan, assignee. Japan Patent 10202257. 4 August 1998. 129:166018 CA.

635. Yamanaka, Osamu, Tadanobu Iwasa, Masato Tamaki, Kazuhiro Sakai, and Toshio Yamaguchi, inventors. "Air Conditioning Apparatus with Photocatalytic Titania-Coated Duct for Air Purification Function." Toyoda Gosei Kk, Japan, assignee. Japan Patent 09038487. 10 February 1997. 126:254784CA.

636. Yamanaka, Osamu, Tadanobu Iwasa, Masato Tamaki, Kazuhiro Sakai, and Toshio Yamaguchi, inventors. "Anti-Mold Deodorizing Sheets." Toyoda Gosei Kk, Japan, assignee. Japan Patent 09038191. 10 February 1997. 126:242060 CA.

637. Yamanaka, Osamu, Tadanobu Iwasa, Masato Tamaki, Kazuhiro Sakai, and Toshio Yamaguchi, inventors. "Disinfection and Deodorization Box Having Titania Photocatalyst for Air Purification." Toyoda Gosei Kk, Japan, assignee. Japan Patent 09038190. 10 February 1997. 126:254782 CA.

638. Yamanaka, Osamu, Tadanobu Iwasa, Masato Tamaki, Kazuhiro Sakai, and Toshio Yamaguchi, inventors. "Electric Fans with Photocatalytic Titania-Coated Blades for Air Purification Function." Toyoda Gosei Kk, Japan, assignee. Japan Patent 09038189. 10 February 1997. 126:254781 CA.

639. Yamanaka, Osamu, Tadanobu Iwasa, Masato Tamaki, Kazuhiro Sakai, and Toshio Yamaguchi, inventors. "Photocatalytic Apparatus for Air and Water Purification." Toyoda Gosei Kk, Japan, assignee. Japan Patent 09038503. 10 February 1997. 126:242062 CA.

640. Yamane, Atsushi, Kazunori Orii, and Shiro Kumakawa, inventors. "Unglazed Pottery Having Photocatalytic Coating and Manufacture Thereof." Aroban Co., Ltd., Japan, and Teijin Ltd., assignees. Japan Patent 10259078. 29 September 1998. 129:249585 CA.

641. Yamashita, Tsuneo, inventor. "Fluorine-Containing Materials Including Photocatalysts." Daikin Industries, Ltd., Japan, assignee. Japan Patent 10306189. 17 November 1998. 129:344084 CA.

642. Yamashita, Tsuneo, inventor. "Fluoropolymer Materials Containing Photocatalysts." Daikin Industries, Ltd., Japan, assignee. Japan Patent 10309786. 24 November 1998. 130:53394 CA.

643. Yamashita, Tsuneo and Tadashi Higashiura, inventors. "Weather-Resistant Fluoropolymer Coating Composition.” Daikin Industries, Ltd., Japan, assignee. World Patent WO. 9846688. A1. 22 October 1998. 129:317698 CA. 
644. Yamazaki, Hiroshi, Masayuki Murabayashi, Shigeru Katsumata, and Kenji Shiozawa, inventors. "Method and Apparatus for Decomposition of Volatile Organic Compounds." Adeka Engineering K.K., Japan, assignee. Japan Patent 09155337. 17 June 1997. 127:152731 CA.

645. Yanagi, Yasuo, Hiroaki Onoishi, Motoo Noumura, Hiroshi Hosokawa, Kozo Mitsuse, and Teruyuki Yamada, inventors. "Deodorant Acrylic Fibers with Excellent Lightfastness." Mitsubishi Rayon Co., Ltd., Japan, assignee. Japan Patent 10245721. 14 September 1998. 129:261684CA.

646. Yano, Daisaku, inventor. "Apparatus and Process for Treatment of Toxic Substance-Containing Water.” Japan Organo Co., Ltd., Japan, assignee. Japan Patent 10113657. 6 May 1998. 129:19478 $C A$.

647. Yano, Daisaku, inventor. "Treatment of Toxic Substances Contained in Water." Japan Organo Co., Ltd., Japan, assignee. Japan Patent 10113658. 6 May 1998. 129:19479 CA.

648. Yasu, Toshinori, inventor. "Method and Apparatus for Washing of Pachinko Ball." Amutetsukusu K.K., Japan, assignee. Japan Patent 10057614. 3 March 1998. 128:233867 CA.

649. Yasuda, Kazumasa, inventor. "Exhaust as Purifying Apparatus Comprising Photocatalyst." Mitsubishi Motors Corp., Japan, assignee. Japan Patent 10309438. 24 November 1998. 130:6903 $C A$.

650. Yasuho, Toshio, inventor. "Accelerated Weathering Test for Fluoropolymer Coatings Containing Titanium Dioxide with Good Correlation with Outdoor Test and Designing Coating Materials." Nippon Paint Co., Ltd., Japan, assignee. Japan Patent 09119893. 6 May 1997. 127:67404 CA.

651. Yokohama, Kanahira and Tazaemon Masuda, inventors. "Wood Impregnated with Photocatalytic Substances and Its Processed Products.” Japan, assignee. Japan Patent 10217209. 18 August 1998. 129:218155 CA.

652. Yokoji, Eichiro and Toshitaka Origasa, inventors. "Window with Titania Photocatalyst for Indoor Air Purification.” Dainippon Printing Co., Ltd., Japan, assignee. Japan Patent 10196229. 28 July 1998. 129:165542 CA.

653. Yoneda, Takashige, Takeshi Morimoto, Manami Hirotani, and Eiji Endo, inventors. "Coating Compositions with Photocatalytic Activity.” Asahi Glass Co., Ltd., Japan, assignee. Japan Patent 09328336. 22 December 1997. 128:131451 CA.

654. Yoshida, Yukio, inventor. "Photocatalyst Reactive Fibers and Photoreaction Apparatus for Deodorization and Disinfection." Seiwa Electric Co., Ltd., Japan, assignee. Japan Patent 10071322. 17 March 1998. 128:234537 CA.

655. Yoshikawa, Masato, Satoko Noguchi, Nobuko Kato, and Kazuo Naito, inventors. "Household Furnishing Coated with Photocatalyst for Soilproofing.” Bridgestone Corp., Japan, assignee. Japan Patent 10072664. 17 March 1998. 128:223774 CA.

656. Yoshikawa, Masato and Tomoko Noguchi, inventors. "Metal Oxide Photocatalysts." Bridgestone Corp., Japan, assignee. Japan Patent 10066879. 10 March 1998. 128:221204 CA.

657. Yoshikawa, Masato and Tomoko Noguchi, inventors. "Bath Water Circulating and Filtering Apparatus.” Bridgestone Corp., Japan, assignee. Japan Patent 10071311. 17 March 1998. 128:221406 CA. 
658. Yoshimura, Kaoru, inventor. "Titania Thin Film-Coated Transparent Material and Aluminum Sash, Household Goods, Automobile Window, and Display Case.” Gunma Tobi K.K., Japan, assignee. Japan Patent 09255366. 30 September 1997. CA 127:297529.

659. Yoshimura, Kaoru, inventor. "Photofunctional Transparent Members for Vehicles." Gunma Tobi K.K., Japan, assignee. Japan Patent 09301740. 25 November 1997. 128:15727 CA.

660. Zota, Hiroshi and Junichirou Arai, inventors. "Apparatus for Treatment of Air and Water by Photocatalyst.” Daikin Industries, Ltd., Japan, assignee. Japan Patent 09314137. 9 December 1997. 128:92926 CA.

\subsection{Address for Sending Corrections or Additions to the Bibliography}

Address to send corrections or references to work appearing prior to 1996 that may have been left out of the list of references in this and the previous report:

Dr. Daniel M. Blake

National Renewable Energy Laboratory

1617 Cole Blvd., MS 1617

Golden, CO 80401-3393

Email: daniel blake@,nrel.gov 


\subsection{Acknowledgements}

I am grateful to Ms. Al Berger for providing the literature searches that are the basis for the content of the reports in this series; to Ms. Patricia Haefele for putting the report in its final form; to Ms. Stefanie Woodward for editing the report; and to those of you that have encouraged me to continue this series on the literature of a very fascinating area of research and development. I am also grateful for support from the Environmental Management Science, Hybrid Vehicle, and Building Energy Technology Programs of the U. S. Department of Energy and the Center for Indoor Air Research during the preparation of this report. 


\subsection{Distribution List}

Dr. Hussain Al-Ekabi

Science and Technology Integration

10D Collip Circle, Suite 110

London, Ontario N6G 4X8

CANADA

Dr. Manuel Romero Alvarez

CIEMAT-IER

Avda. Complutense 22

28040 Madrida

SPAIN

Professor Masakazu ANPO

Dept. of Applied Chemistry, College of Engineering

Osaka Prefecture University

Gakuen-cho. 1-1

Sakai, Osaka 599-8531, JAPAN

Dr. Marc Anderson

University of Wisconsin

Water Chemistry Program

660 North Park Street

Madison, WI 53706

Dr. Klaus-Dieter Asmus

University of Notre Dame

Radiation Laboratory

Notre Dame, IN 46556

Professor Jan Augustynski

Universite de Geneve

Chimie Qppliquee, Sciences II

30 quai E. Ansermet, $\mathrm{CH}-1211$ Geneve 4

SWITZERLAND
Dr. Jaime Benitez

Chemical Engineering Department

R.U.M. Mayaquez

Puerto Rico 00681

Professor Elliot R. Bernstein

Department of Chemistry

Colorado State University

Fort Collins, CO 80523

Dr. Julian Blanco

CIEMAT-PSA

Aptdo, 22

E-4200 Tabernas (Almeria)

SPAIN

Dr. Jim Bolton

Bolton Photosciences, Inc.

92 Main Street

Ayr, Ontario

CANADA NOB 1E0

Dr. Paul Bonczyk

UTRC - M.S. 30

Silver Lane

East Hartford, CT 06108

Mr. Brian Butters

General Manager Purifics

161 Mallard Road

Hyde Park, Ontario,

CANADA NOM $1 Z 0$ 
Dr. Detlef Bahnemann

Institut fur Solarenergieforschung $\mathrm{GmbH}$

Sokelantstrasse 5

D-30165 Hannover

GERMANY

Dr. Alan Bard

University of Texas at Austin

Department of Chemistry

Austin, TX 78712-1167

Dr. Eileen Chant

University of Turabo

School of Engineering

Apartado 3030

Gurabo, Puerto Rico 00778

Mr. Daniel Chen

Senior Research Engineer

Process Technology Lab, 3M Corporate Research

3M Center, Building 208-1-01

St. Paul, MN 45144-100

Mr. Preston Clements

5206 Fairfax NW

Albuquerque, NM 87114
Dr. Nelson Cardona

University of Puerto Rico at Mayaguez

Chemical Engineering Department

P.O. Box 5000

Mayaguez, Puerto Rico 00681-5000

Mr. David De Villiers

Photocatalytic Research Group, Dept. of Chemistry

University of Stellenbosch

Stellenbosch 7600

SOUTH AFRICA

Dr. Neelhanth G. Dhere

Florida Solar Energy Center

300 State Road 401

Cape Canaveral, FL 32920
Dr. Jose M. Dona

Departmento de Quimica

Universidad de Las Palmas de Gran Canaria

Campus Universitario de Tafira

35017 Las Palmas, SPAIN

Dr. Scott H. Elder

Materials and Chemical Sciences Dept. Pacific Northwest National Laboratory 902 Battelle Boulevard, P. O. Box 999

Richland, WA 99352

Dr. John Falconer

University of Colorado

Department of Chemical Engineering

Boulder, CO 80309

Mr. Jim Freihaut

United Technologies Research Center

411 Silver Lane, MS 129-24

East Hartford, CT 06108 
Mr. Roger Davenport

Science Applications International Corporation 15000 W. $6^{\text {th }}$ Ave., Suite 202

Golden, CO 80401

Dr. John Gannon

Leveraged Biology

DuPont Central Research \& Development

P. O. Box 6101, Glasgow 300

Newark, DE 19714-6101

Dr. Bill Glaze

University of North Carolina

Environmental Science \& Engineering

Rosenau Hall, CB \#7400

Chapel Hill, NC 27599-7400

Dr. A. Jimenez Gonzalez

Centro de investigacion en Energia-UNAM

Privada Xochicalco S/N

Col. Centro, Temixco. A.P. 34

62580 Temixco, Morelos, MEXICO

Mr. James Goodrich

Environmental Scientist U. S. EPA

Drinking Water Research

26 W. Martin Luther King Dr.

Cincinnati, $\mathrm{OH} 45268$

\section{Dr. Yogi Goswami}

Professor of Mechanical Engineering

University of Florida, College of Engineering

220 MEB

Gainesville, FL 32611-2050

Professor Claes-Goran Granqvist

Uppsala University

Teknikum

Box 534, S-751 21 Uppsala

SWEDEN
Dr. Karl-Heinz Funken

German Aerospace Research Development

Energy Technology Division

D-51140 Koln

GERMANY

Dr. Michael Gratzel

Institut de Chemic Physique

EPFL

1015 Lausanne

SWITZERLAND

Dr. Barbara L. Green

441 West Lake Road

Fitzwilliam, NH 03447

Dr. Charles B. Greenberg

PPG Industries, Inc.

Glass Technology Center

P. O. Box 11472

Pittsburg, PA 15238-0472

Dr. Chantal Guillard

Laboratoire CNRS de photocatalyse catalyse et environnemer centrale de Lyon

36 av guy de collongue

69131 ECULLY Cedex, FRANCE

Dr. Adam Heller

University of Texas

Department of Chemical Engineering

Austin, TX 78712-1062

Mr. Ephraim Heller

E. Heller \& Company

1311 Harbor Bay Parkway, Suite 1000

Alameda, CA 94501 
Dr. Vicki Grassian

University of lowa

lowa City, IA 52242

Dr. Edwin R. Hendrickson

Leveraged Biology

DuPont Central Research \& Development

P. O. Box 6101, Glasgow 300

Newark, NJ 19714-6101

Dr. Jean-Marie Herrmann

Photocatalyse, catalys et Environnement

Ecole Centrale de Lyon

B.P. 163, 69131 ECULLY-Cedex

FRANCE

\section{Darrick Heyd}

Surface Science Center

University of Pittsburgh

132 Alumni Hall

Pittsburgh, PA 15260

Dr. Michael Hoffman

W. M. Keck Laboratories

California Institute of Technology

Pasadena, CA 91125

Dr. Takashi Ibusuki

National Institute for Resources and Environment

Agency of Industrial Science and Technology

16-3 Onogawa, Tsukuba, Ibaraki

305 JAPAN

Dr. Shinichi Ichikawa

Power \& Industrial Systems R \& D Laboratory

Hitachi Ltd.

832-2 Horiguchi, Hitachinaka-shi, Ibaraki-ken, 312-0034 JAPAN
Mr. Bob Henderson

Matrix Photocatalytic, Inc.

22 Pegler Street

London, Ontario

CANADA N5Z 2B5

Dr. Antonio Jimenez

Centro De Investigacion en Energia

Priv. Xochicalco S/No., Col. Centro, Apartado Postal No 34

Temixco, Mor 62580

MEXICO

Dr. Prashant V. Kamat

University of Notre Dame

Radiation Laboratory

Notre Dame, IN 46556-0579

Dong H. Kim

Korea Electric Power Corporation

Research Center/Chemistry and Environmental Dept.

103-16, Munji-Dong

Yusong-ku Taejon, 305-380

SOUTH KOREA

Mr. J. R. Kittrell, President

KSE, Inc.

P. O. Box 368

Amherst, MA 01004

Dr. J. Kiwi

Federal Institure of Technology

E.P.F.L. Chimie Physipue

1015 Lausanne

SWITZERLAND

Hiromi Koga

Functional Materials Group

Ishihara Sangyo Kaisha, Ltd.

1, Ishihara-Cho, Yokkaichi-City Mie-Pref.

510-0842 JAPAN 
Dr. John Ireland

U. S. EPA

Office of Research and Development 26 W. Martin Luther King Dr.

Cincinnati, $\mathrm{OH} 45268$

Mr. Charles Kutal

University of Georgia

Department of Chemistry

Athens, GA 30602-2556

Corinne Lehaut

TiO2 Specialities Business Unit

52 rue de la Haie Coq

F-93308 Aubervilliers cedex

FRANCE

Dr. Shulong Li

Milliken Research Corp.

920 Milliken Rd., M-405

Spartanburg, SC 29304

Dr. Yuzhuo Li

Clarkson University

Dept. of Chemistry

Potsdam, NY 13699-5810

Dr. Norman Lichtin

Boston University

Chemistry Department

590 Commonwealth Avenue

Boston, MA 02215

Dr. Bruce Lighthart

Microbial Aerosol Research Laboratory

10975 Doll Road

Monmouth, OR 97361
Dr. Carl Koval

University of Colorado

Department of Chemistry

Boulder, CO 80309-0215

Dr. Noam Lior University of Pennsylvania

Dept. of Mechanical Engineering

297 TB/6315

Philadelphia, PA 19104-6315

Dr. Sixto Malato

CIEMAT-PSA

Aptdo. 22

E-04200 Tabernas (Almeria)

SPAIN

Dr. Ted Mao

Trojan Technologies, Inc.

UV Disinfection Systems

3020 Gore Road

London, Ontario, CANADA N5V 4T7

Dr. Tom McKinnon

Colorado School of Mines

Chemical \& Petroleum Engineering

Golden, CO 80401

Mr. Richard A. Miller

Zentox Corporation

2140 NE $36^{\text {th }}$ Ave

Ocala, FL 34470

Dr. Allan Jeff Mohr

West Desert Test Center

Dugway Proving Ground

Dugway, UT 84022-5000 
Mr. Clovis Linkous, Research Engineer

Florida Solar Energy Center

300 SR 401

Cape Canaveral, FL 32920

Koji Nakano, Chairman

Advanced UV, Inc.

Sequoia Commerce Center

19210 Van Ness Avenue

Torrance, CA 90501

Dr. Douglas Neckers

Bowling Green State University

Center for Photochemical Science

Bowling Green, OH 43403

Dr. J. H. Nelson

University of Nevada at Reno

Department of Chemistry

Reno, NV 89557

Dr. David E. Nicodem

Instituto de Quimica-UFRJ, CT

Bloco A, Ilha do Fundao, 21949-900

Rio de Janeiro, JR

BRAZIL

Dr. Satoshi Nishikata

Senior Research Engineer

Fuji Electric Corporate R \& D, Ltd.

2-2-1 Nagasaka, Yokosuka Kanagawa 240-0194

JAPAN

Dr. Richard Noble

University of Colorado, Boulder

Dept. of Chemical Engineering

Engineering Center, CH1-60, Campus Box 424

Boulder, CO 80309-0424
Dr. Nazim Muradov

Research Associate

Florida Solar Energy Center

1679 Clearlake Rd.

Cocoa, FL 32922-5703

Mr. Kevin O'Shea

Florida International University

College of Arts \& Sciences

Miami, FL 33199

Dr. David Ollis

Distinguished Professor

N. C. State University

Dept. of Chemical Engineering

Raleigh, NC 27695-7905

Thomas Orlando

Environmental Molecular Sciences Lab K8-88

Pacific Northwest National Lab

Richland, WA 99335

Charles H. F. Peden

Environmental Molecular Sciences Laboratory, Mail Stop K8-c

Pacific Northwest National Laboratory

902 Battelle Boulevard, P. O. Box 999

Richland, WA 99352

Dr. Ezio Pelizzetti

Institute di Chimica Fisica

Universita di Parma

43100 Parma

ITALY

Dr. Jesus Perez Pena

Universidad de Las Palmas de Gran Canaria

Campus universitario de Tafira

Codigo postal 35017

SPAIN 
Dr. Stephen O'Brien

Department of Chemistry

UCSB

Santa Barbara, CA 93106-9510

Dr. Gary Peyton

Illinois State Water Survey

Office of Environmental Chemistry

1008 S. Mattis Ave.

Champaign, IL 61820

Dr. Pierre Pichat

U.R.A. au C.N.R.S.

Ecole Central de Lyon

B.P.F-69131 163, Ecully Cedex

FRANCE

Sigrid H. Pilgrim

Intercon Research Associates Ltd.

6865 Lincoln Ave

Lincolnwood, IL 60646-2644

Dr. Michael Prairie

Chemical Engineer

Sandia National Laboratories

P.O. Box 5800, Division 6216

Albuquerque, NM 87185-0703

Dr. Charles Quinlan

KSE, Inc.

P.O. Box 368

Amherst, MA 01004

Dr. Krishnan Rajeshwar University of Texas at Arlington

Dept. of Chemistry \& Biochemistry

Box 19065

Arlington, TX 76019-0065
Jose Peral Perez

Department de Quimica

Edifici $\mathrm{Cn}$

Universitat Autonoma de Barcelona

08193-Bellaterra, Barcelona, SPAIN

Dr. Gregory B. Raupp

Arizona State University

Dept. of Chemical and Biological

Materials Engineering

Tempe, AZ 85287-6006

Mr. John S. Reese

Zentox Corporation

2140-100 N.E. $36^{\text {th }}$ Ave.

Ocala, FL 34470

Dr. R. George Rizeq

Energy and Environmental Research Corp.

18 Mason

Irvine, CA 92618

Mr. Juan Rodriquez

Lab. De Peliculas delgadas

Universidad Nacional de Ingeneria

Apartado 31-139

Lima, PERU

Mr. Beningo Sanchez

CIEMAT-IER

Avda. Complutense 22

E-28040 Madrid

SPAIN

Wayne Schubert

Jet Propulsion Laboratory

4800 Oak Grove Drive

Mail Stop 89

Pasadena, CA 91109 
Tijana Rajh

Argonne National Laboratory

Chemistry Division

Argonne, IL 60439

Dr. Nick Serpone

Concordia University

11455 Demaisonneuve Blvd.

West Montreal, H3G-1M8

CANADA

Dr. Raymond Sierka

University of Arizona

Dept. of Civil Engineering and Engineering

Mechnics

Tuscon, AZ 85721

Dr. Wayde Smith

UTRC-M.S. 30

Silver Lane

East Hartford, CT 06108

Dr. Prem K. Sreenivasan

Colgate-Palmolive Company

909 River Road

P. O. Box 1343

Piscataway, NJ 08855-1343

Mr. Sam Stevens, President

Solarchem Environmental Systems

130 Royal Crest Court

Markham, Ontario L3R OA1

CANADA

Mr. Ken-ichirou Suzuki

Toyota Central R \& D Labs

41-1 Yokomichi, Nagakute

Nagakute-cho, Aishi-gun

Aichi-ken 480-11 JAPAN
Dr. Jeffrey Sczechowski

California Polytechnic State University

Civil \& Environmental Engineering Dept.

San Luis Obispo, CA 93407

Dr. Koji Takeuchi

National Institute for Resources and Environment Agency of Industrial Science and Technology 16-3 Onogawa, Tsukuba

Ibaraki 305, JAPAN

Dr. Tsukasa Torimoto

Graduate School of Engineering

Osaka University

Yamada-oka 2-1, Suita, Osaka 565-0871

JAPAN

Dr. Kasthuri Venkateswaran

California Institute of Technology

Mail Code 89-5

4800 Oak Grove Dr.

Pasadena, CA 91109

Dr. Pam Vercellone-Smith

Rothe Development, Inc.

P. O. Box 42

Gunpowder Branch

Aberdeen Proving Ground, MD 21010

Dr. Yuji Wada

Material \& Life Science

Osaka University

Yamadaoka 2-1, Suita, Osaka 565-0871

JAPAN

Mitsuru Watanabe

Ishihara Sangyo Kaisha, Ltd.

R \& D Application Laboratory

1, Ishihara-Cho, Yokkaichi-City

MIE-Pref, 510-0842 JAPAN 
Dr. Ali T-Raissi

Florida Solar Energy Center

1679 Clear Lake Rd.

Cocoa, FL 32922-5703

Dr. Richard Watts

Washington State University

Department of Civil Engineering

Pullman, WA 99164-2910

Mr. David Wickham

TDA Research

12421 W. $49^{\text {th }}$ Ave.

Wheatridge, CO 80033

Mr. Frank Wilkins

U. S. Dept. of Energy

EE-222 5G-067

1000 Independence Ave. SW

Washington, DC 20585

Dr. Aaron Wold

Brown University

Department of Chemistry

Providence, RI 02912

Dr. Suzuko Yamazaki

Department of Chemistry

Yamaguchi University

1677-1 Yoshika

Yamaguchi, 753-8512, JAPAN
Dr. Toshiya Watanabe

The University of Tokyo

Research Center for Advanced Science and Technology 4-6-1 Komaba, Meguro-ku

Tokyo 153-8904 JAPAN

Dr. Zhou Yue-Xi

Water Environmental Institute

Chinese Research Academy of Environmental Sciences

Beiyuan, An Wai, Beijing

CHINA 100012

Dr. John Yates

University of Pittsburgh

Department of Chemistry

Chevron 234

Pittsburgh, PA 15260

Dr. Po Lock Yue

Hong Kong University of Science \& Technology

Room 4571, Academic Building

Clear Water Bay

Kowloon, Hong Kong CHINA

Dr. R. G. Zepp

U.S. EPA

960 College Station Road

Athens, GA 30613-7799 
HNA 


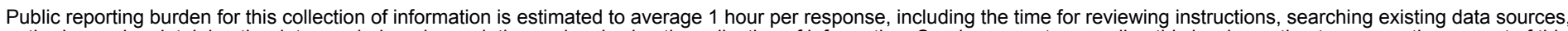

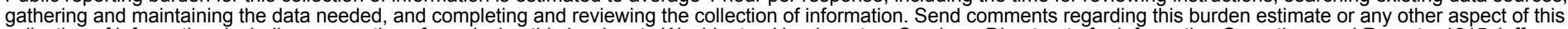

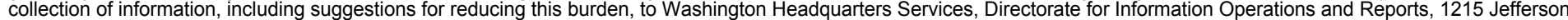
Davis Highway, Suite 1204, Arlington, VA 22202-4302, and to the Office of Management and Budget, Paperwork Reduction Project (0704-0188), Washington, DC 20503.

\begin{tabular}{|l|l|l}
\hline 1. AGENCY USE ONLY (Leave blank) & $\begin{array}{l}\text { 2. REPORT DATE } \\
\text { August } 1999\end{array}$ & $\begin{array}{l}\text { 3. REPORT TYPE AND DATES COVERED } \\
\text { Technical Report }\end{array}$ \\
\hline
\end{tabular}

\section{TITLE AND SUBTITLE}

5. FUNDING NUMBERS

Bibliography of Work on the Heterogeneous Photocatalytic Removal of Hazardous Compounds from Water DO6E4300

\section{AUTHOR(S)}

D.M. Blake

7. PERFORMING ORGANIZATION NAME(S) AND ADDRESS(ES)

8. PERFORMING ORGANIZATION REPORT NUMBER

National Renewable Energy Laboratory

1617 Cole Boulevard

Golden, CO 80401-3393

9. SPONSORING/MONITORING AGENCY NAME(S) AND ADDRESS(ES)

10. SPONSORING/MONITORING AGENCY REPORT NUMBER

National Renewable Energy Laboratory

1617 Cole Boulevard

NREL/TP-570-26797

Golden, CO 80401-3393

11. SUPPLEMENTARY NOTES

12a. DISTRIBUTION/AVAILABILITY STATEMENT

12b. DISTRIBUTION CODE

National Technical Information Service

U.S. Department of Commerce

5285 Port Royal Road

Springfield, VA 22161

13. ABSTRACT (Maximum 200 words) The subject of this report is chemistry and engineering for the application of heterogeneous photocatalysts. The state of the art in catalysts are forms of titanium dioxide or modifications thereof, but work on other heterogeneous catalysts is included.

14. SUBJECT TERMS

titanium dioxide, catalyst, bibliography, photocatalyst

15. NUMBER OF PAGES 160

16. PRICE CODE

17. SECURITY CLASSIFICATION OF REPORT
18. SECURITY CLASSIFICATION OF THIS PAGE
19. SECURITY CLASSIFICATION OF ABSTRACT
20. LIMITATION OF ABSTRACT

Standard Form 298 (Rev. 2-89) Prescribed by ANSI Std. Z39-18 298-102 